\title{
Assessment of the Integrity of Spent Fuel Assemblies Used in Dry Storage Demonstrations at the Nevada Test Site
}

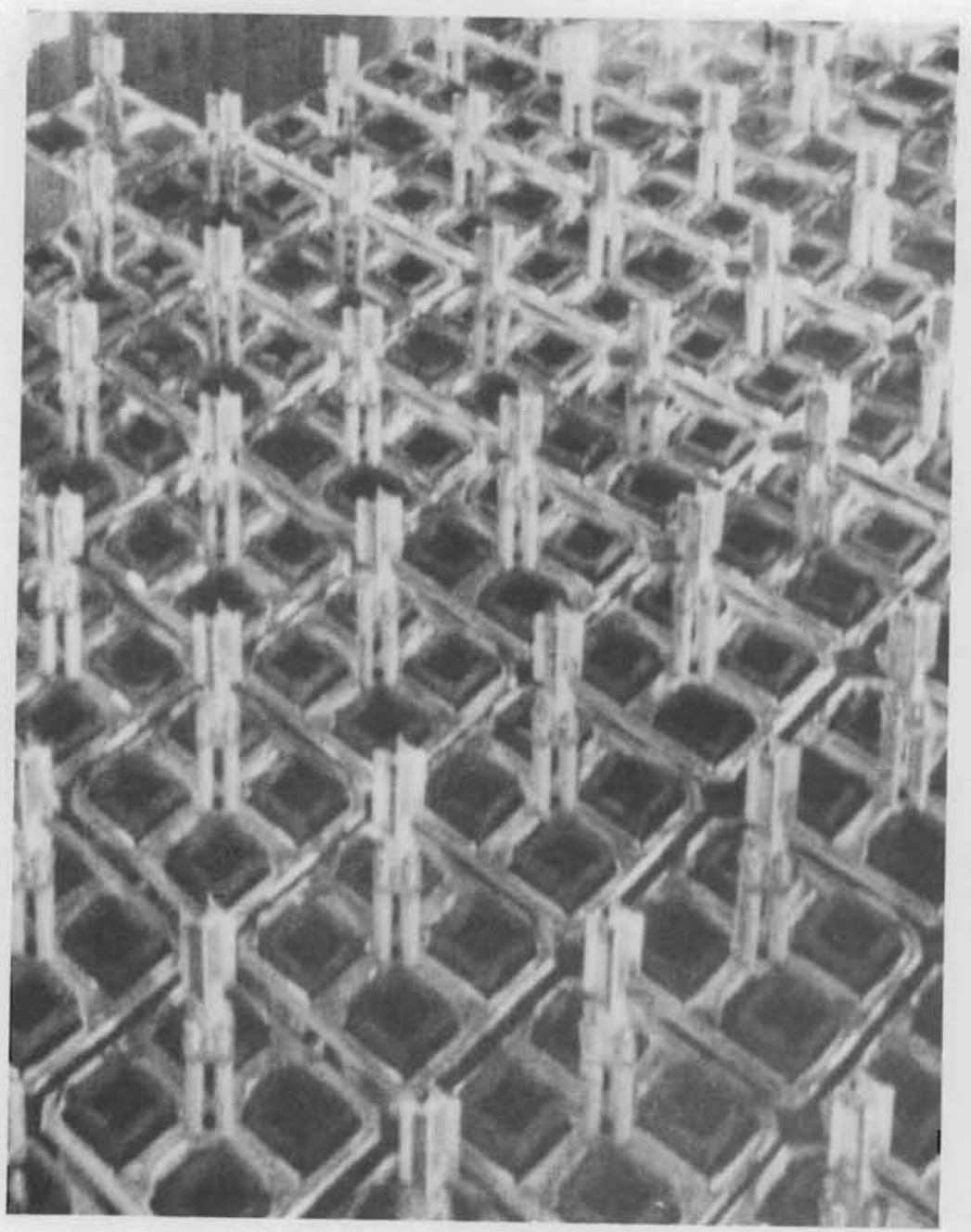

July 1987

Prepared for the U.S. Department of Energy under Contract DE-AC06-76RLO 1830

Pacific Northwest Laboratory Operated for the U.S. Department of Energy by Battelle Memorial Institute 


\section{DISCLAIMER}

This report was prepared as an account of work sponsored by an agency of the United States Government. Neither the United States Government nor any agency thereof, nor Battelle Memorial Institute, nor any of their employees, makes any warranty, expressed or implied, or assumes any legal liability or responsibility for the accuracy, completeness, or usefulness of any information, apparatus, product, or process disclosed, or represents that its use would not infringe privately owned rights. Reference herein to any specific commercial product, process, or service by trade name, trademark, manufacturer, or otherwise, does not necessarily constitute or imply its endorsement, recommendation, or favoring by the United States Government of any agency thereof, or Battelle Memorial Institute. The views and opinions of authors expressed herein do not necessarly state or reflect those of the United States Government or any agency thereof, or Battelle Memorial Institute.

\section{PACIFIC NORTHWEST LABORATORY operated by \\ BATTELLE MEMORIAL INSTITUTE for the \\ UNITED STATES DEPARTMENT OF ENERGY under Contract DE-AC06-76RLO 1830}

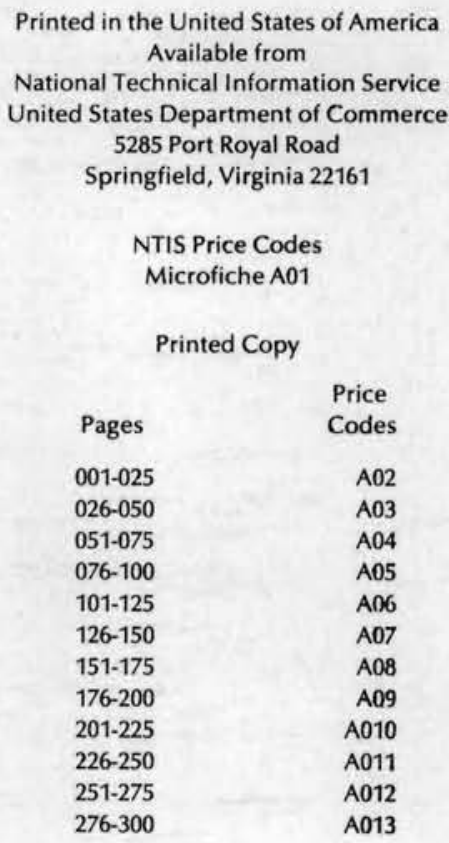




\section{4}

ASSESSMENT OF THE INTEGRITY OF SPENT FUEL ASSEMBLIES USEO IN ORY STORAGE DEMONSTRATIONS AT THE NEVADA TEST SITE
A. B. Johnson Jă
F. R. Zaloudek
E. R. Gilbert
I. S. Levy

July 1987

\section{Prepared for}

the U.S. Department of Energy

under Contract DE-AC06-76RLO 1830

Pacific Northwest Laboratory

Richland, Washingt on 99352

(a) Westinghouse-Electric Corporation 


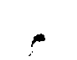

$+$

-

- 
SUMMARY

This report summarizes the histories of 17 Zircaloy-clad spent fuel assemblies used in dry storage tests and demonstrations at the Engine Maintenance and Disassembly (EMAD) and Climax facilities at the Nevada Test Site (NTS). The 18th assembly was shipped to the Battelle Columbus Laboratory (BCL) and remained there for extensive characterization and as a source of specimens for whole-rod and rod-segment dry storage tests. The report traces the history of the assemblies after discharge from the Turkey Point Unit 3 pressurizedwater reactor (1975 and 1977) through shipment (first arrival at EMAD in December 1978), dry storage tests and demonstrations, and shipment by truck cask from EMAD to the Idaho National Engineering Laboratory (INEL) in May/June 1986.

The principal objectives of this report are to assess and document the integrity of the fuel during the extensive dry storage activities at NTS and $B C L$, and to briefly summarize the dry storage technologies and procedures demonstrated in this program.

The extensive dry storage demonstration was conceived and conducted under three federally-funded programs:

Spent Fuel Handling and Packaging Program (SFHPP)

The Commercial Waste and Spent Fuel Packaging Program (CWSFP)

National Waste Terminal Storage Program (NWTSP). Westinghouse Electric Corporation managed the work at EMAD; the Lawrence Livermore National Laboratory managed the work at Climax.

More recent fuel integrity tests and evaluations at EMAD and the preparation of this summary were sponsored by the Commercial Spent Fuel Management (CSFM) program.

The dry storage tests and demonstrations involved the following concepts and facilities: 1) surface drywells (EMAD); 2) deep drywells (425 m underground in the Climax granite formation); 3) concrete silo (EMAD); 4) air-cooled vault (EMAD); 5) electrically-heated module for fuel assembly thermal calibration and testing (EMAD/FAITM). 
The maximum cladding temperatures for fuel assemblies during the various tests and demonstrations are summarized below:

- surface drywells

- deep drywells

- concrete silo (canister)

- vault (lag storage)

- Fuel Temperature Test (FTT)

$\begin{array}{lll}\frac{{ }^{\circ} \mathrm{F}}{452} & & \frac{{ }^{\circ} \mathrm{C}}{233} \\ 452 & & 233 \\ 334 & & 168 \\ 532 & & 278 \\ 527 & & 275\end{array}$

All temperatures were well below the NTS maximum design fuel storage temperature of $716^{\circ} \mathrm{F}\left(380^{\circ} \mathrm{C}\right)$. The maximum vault temperature occurred only over a brief period while a ventilation test was conducted. Subsequently, cladding temperatures in the vault were lower. Not represented in the table are brief calibration tests that raised cladding temperatures on two assemblies: $575^{\circ} \mathrm{F}$ $\left(302^{\circ} \mathrm{C}\right)$ on $\mathrm{B} 43$ and $680^{\circ} \mathrm{F}\left(360^{\circ} \mathrm{C}\right)$ on $\mathrm{D}-15$.

Pretest inspection of the Turkey Point fuel assemblies suggested that the 3468 fuel rods in the NTS program were all sound except for one or more rods in Assembly B41. Elevated cesium indications during shipping cask monitoring suggested leaking fuel. The same assembly also had elevated krypton-85 levels during dry storage canister atmosphere monitoring, appearing to correlate with the earlier indication.

Only one of the fuel rods failed during the dry storage program at NTS. The breach occurred while assembly $\mathrm{B} 02$ was tested in air in the electricallyheated fuel temperature test (FTT). Before the test, the assembly resided in the concrete silo for $3.5 \mathrm{yr}$ and in the vault for 44 months at temperatures below $-350^{\circ} \mathrm{F}\left(177^{\circ} \mathrm{C}\right)$. About two months after the maximum cladding temperature was raised to $527^{\circ} \mathrm{F}\left(275^{\circ} \mathrm{C}\right)$, the krypton-85 and helium concentrations in the cover gas increased abruptly, showing inventories that corresponded to expected releases from a single fuel rod. A calculation based on the Poiseuille equation suggested a cladding hole size on the order of 1 m. The assembly remained in the air test for an additional 22 months on a declining temperature ramp (final temperature $-430^{\circ} \mathrm{F}$ or $220^{\circ} \mathrm{C}$ ). Gas monitoring and post-test visual inspection of the assembly and swipe monitoring did not result in any evidence 
that the cladding defect enlarged or caused significant releases of particulates or fission products. A more complete visual inspection of the Assembly B02 rods is planned during a rod consolidation campaign at INEL.

The demonstrations involved a comprehensive assessment of dry storage technology, including the following activities: pretest shipping; fuel assembly characterization; lag storage (vault); decay heat measurement; encapsulation in canisters (welded and unwelded); emplacement in several types of dry storage facilities; storage; monitoring; retrieval from storage; decapsulation; inspection; fuel assembly and rod behavior investigations; post-test shipping.

After dry storage in the EMAD and Climax facilities, each assembly was inspected and photographed. No visible damage or physical changes were observed.

Cover gas monitoring during the NTS dry storage campaign demonstrated that krypton-85 activity offers a sensitive measure of fuel rod integrity. Low levels of krypton-85 were measurable, even for intact fuel, agreeing with German results. The explanation appears to be that intact assemblies that reside in a reactor that had fuel failures adsorb fission products from the coolant, including krypton that desorbs during dry storage. The failure of a rod in Assembly B02 resulted in a krypton-85 inventory six orders of magnitude above the detection limit $\left(\sim 10^{-2} / \mathrm{pCi} / \mathrm{CC}\right)$ and $\sim$ four orders of magnitude above krypton levels for unbreached assemblies. An assembly with suspected leaking fuel had an intermediate krypton-85 concentration in the cover gas.

The comprehensive program conducted at the Nevada Test Site demonstrated several dry storage concepts with a high degree of safety and technical competence. Of the 3468 irradiated PWR fuel rods in the dry storage tests and demonstrations, only one rod failed, indicating that Zircaloy-clad fuel is highly durable under dry storage conditions and fuel handling represented in the NTS tests and demonstrations. Companion rods heated in the range 900 to $1060^{\circ} \mathrm{F}\left(480\right.$ to $570^{\circ} \mathrm{C}$ ) at the Battelle-Columbus Laboratories also demonstrated durability, even under overtemperature conditions. 
-

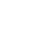




\section{ACKNOWLEDGMENTS}

The authors wish to acknowledge with thanks the assistance of J. B. Wright, H. H. Irby, M. E. Joyner, and K. G. Garey, Westinghouse Electric Corporation, Waste Technology Services Division, and Mr. M. Lewis, PNL, in the assembly and organization of the information provided in this report. Analysis of gas samples and interpretation of results were provided by Lawrence Livermore National Laboratory staff, V. M. Oversby, C. F. Smith, and H. W. Culham. The authors also acknowledge the assistance of D. K. Hilliard for editing and publication assistance.

Preparation of this summary was sponsored by the U.S. Department of Energy under the Commercial Spent Fuel Management Program. 
更

.

- 


\section{CONTENTS}

SUMMARY

ACKNOWLEDGMENTS

vi i

ABBREVIATIONS AND ACRONYMS

$x y$

1.0 INTRODUCTION $\ldots \ldots \ldots \ldots \ldots \ldots \ldots \ldots \ldots \ldots \ldots \ldots \ldots \ldots \ldots \ldots \ldots \ldots \ldots \ldots \ldots \ldots \ldots \ldots \ldots \ldots$

1.1 BACKGROUND ...................................... 2

1.2 OBJECTIVE OF PRESENT STUDY $\ldots \ldots \ldots \ldots \ldots \ldots \ldots \ldots \ldots \ldots \ldots \ldots \ldots \ldots \ldots \ldots$

1.3 SCOPE AND ORGANIZATION OF REPORT ..................... 4

2.0 SPENT FUEL DESCRIPTION $\ldots \ldots \ldots \ldots \ldots \ldots \ldots \ldots \ldots \ldots \ldots \ldots \ldots \ldots \ldots \ldots \ldots \ldots \ldots \ldots$

3.0 HISTORY OF SPENT FUEL DURING DRY STORAGE DEMONSTRATIONS $\ldots \ldots \ldots \ldots \ldots \ldots$

3.1 PRETEST CHARACTERIZATION $\ldots \ldots \ldots \ldots \ldots \ldots \ldots \ldots \ldots \ldots \ldots \ldots \ldots \ldots \ldots \ldots . . \ldots$

3.1.1 Examination of Fuel Assemblies B02, B03, B17,

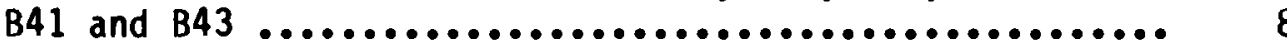

3.1.2 Examinations of Spent Fuel Assemblies D01, D04, and 006

3.2 HANDLING AND TESTING AT EMAD $\ldots \ldots \ldots \ldots \ldots \ldots \ldots \ldots \ldots \ldots \ldots \ldots \ldots \ldots \ldots$

3.2.1 Encapsulation ................................. 16

3.2.2 Drywell Tests .................................. 18

3.2.3 Concrete Silo Tests ............................ 22

3.2.4 Fuel Assembly Internal Temperature Measurement

Testing ..................................... 25

3.2.5 Air-Cooled Vault Tests .......................... 28

3.2.6 Decay Heat Measurements ........................... 31

3.3 SPENT FUEL TEST AT CLIMAX $\ldots \ldots \ldots \ldots \ldots \ldots \ldots \ldots \ldots \ldots \ldots \ldots \ldots \ldots \ldots \ldots$

3.3.1 Post-Test Evaluation of Fuel at EMAD .............. 37

3.4 RELATED ROD AND ROD SEGMENT TESTING $\ldots \ldots \ldots \ldots \ldots \ldots \ldots \ldots \ldots \ldots \ldots . . \ldots$

3.4.1 Tests of Single Rods Under Dry Storage Conditions ...... 38 
3.4.2 Oxidation Testing of Rod Segments .................. 39

4.0 FUEL THERMAL HISTORY $\ldots \ldots \ldots \ldots \ldots \ldots \ldots \ldots \ldots \ldots \ldots \ldots \ldots \ldots \ldots \ldots . \ldots \ldots . \ldots \ldots$

5.0 FUEL INTEGRITY MONITORING $\ldots \ldots \ldots \ldots \ldots \ldots \ldots \ldots \ldots \ldots \ldots \ldots \ldots \ldots \ldots . \ldots$

5.1 MONITORING OF GAS SAMPLES $\ldots \ldots \ldots \ldots \ldots \ldots \ldots \ldots \ldots \ldots \ldots \ldots \ldots . . . \ldots$

5.1.1 Sampling Method for Unwelded Canisters .............. 49

5.1.2 Sample Method for FAITM Test Canister ............... 49

5.1.3 Sample Method for Sealed Drywell and SFT-C Canisters ... 50

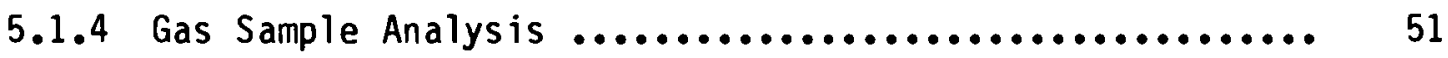

5.1.5 Results of Gas Sample Monitoring Program ............ 51

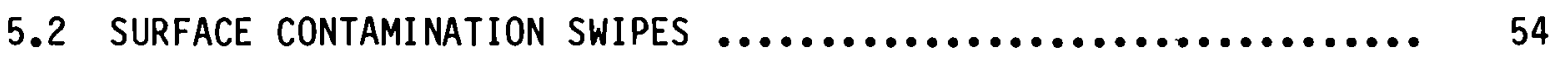

6.0 CONDITION OF THE EMAD FACILITY FOLLOWING TESTING .............. 57

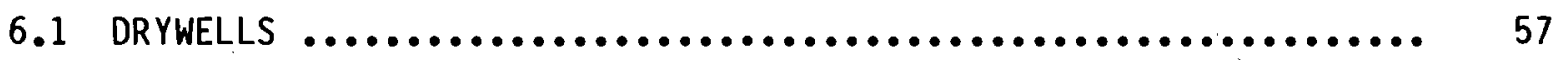

6.2 CONCRETE SILO $\ldots \ldots \ldots \ldots \ldots \ldots \ldots \ldots \ldots \ldots \ldots \ldots \ldots \ldots \ldots \ldots \ldots . \ldots \ldots \ldots$

6.3 AIR-COOLED VAULT (LAG STORAGE PIT) ..................... 58

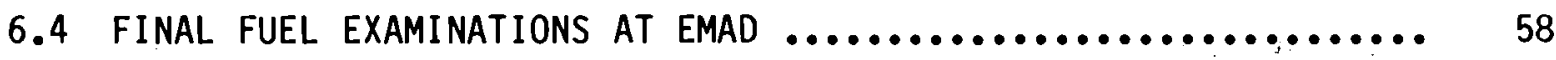

6.5 SUMMARY OF RESULTS OF FINAL EXAMINATIONS $\ldots \ldots \ldots \ldots \ldots \ldots \ldots . . . \ldots 9$

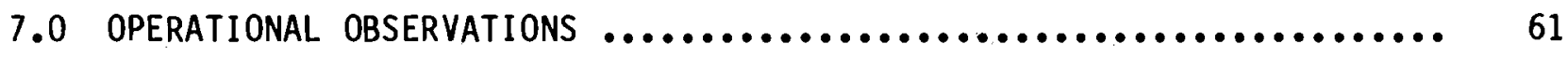

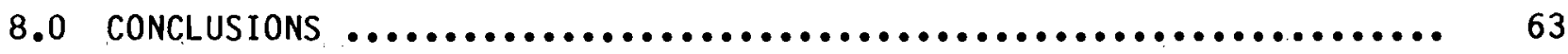

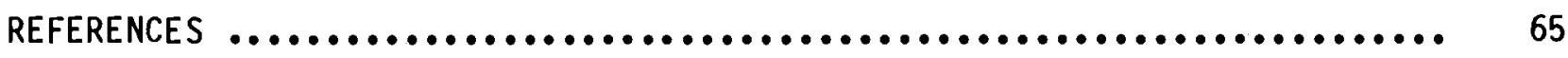

APPENDIX A - HANDLING HISTORIES OF SPENT FUEL ASSEMBLIES $\ldots \ldots \ldots \ldots \ldots \ldots$ A.1

APPENDIX B - DECAY HEAT MEASUREMENT .......................... B.1

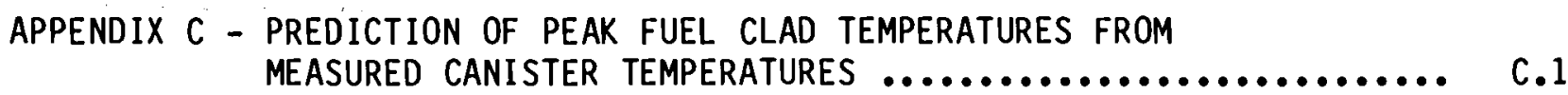

APPENDIX D - FISSION GAS ANALYSIS RESULTS OBTAINED

BY DRILLING SELECTED FUEL RODS $\ldots \ldots \ldots \ldots \ldots \ldots \ldots \ldots \ldots \ldots, 0.1$

APPENDIX E - SUMMARY OF CLAD INTEGRITY DATA $\ldots \ldots \ldots \ldots \ldots \ldots \ldots \ldots \ldots \ldots$ E.1 


\section{FIGURES}

3.1 A Summary of the Histories of the 17 Fuel Assembiies Used in the Dry Storage Demonstrations at the Nevada Test Site ......... 9

3.2 Post-Test Photograph of Top Section of Fuel Assembly B02 ........ 11

3.3 Post-Test Photograph of Center Section of B02 ................ 12

3.4 Post-Test Photograph of Bottom Section of B02 ............... 13

3.5 Typical Canister Used to Encapsulate the Spent Fuel Assemblies .... 17

3.6 The Arrangement of a Typical Drywell Containing an Encapsulated Fuel Assembly ................................. 19

3.7 The Cross-Section View of a Typical Drywell Showing Important Dimensions

3.8 Arrangement of Drywells Showing Locations of

Soil Instrumentation

3.9 Fuel Transfer Vehicle and Shield Used to Transport

Encapsulated Fuel Assemblies To and From the Drywells ............. 21

3.10 The Arrangement of the Sealed Storage Cask Used in the

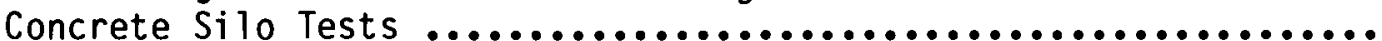

3.11 A Cross-Section of the Concrete Storage Cask Showing Important Measurements

3.12 The General Arrangement of the Apparatus Used for the Fuel Assembly Internal Temperature Measurement Tests and the Fuel

Temperature Tests

3.13 Arrangement of the EMAD Lag Storage Pit Used in the Air-Cooled Vault Tests

3.14 Cross Section of Lag Storage Pit Facility Showing Important Measurements

3.15 Plan View of Lag Storage Pit Facility Showing the Relationship Between Individual Storage Locations

3.16 General Arrangement of the Boiling Water Calorimeter Used in the Decay Heat Measurements

3.17 Calorimeter System Flow and Instrumentation Diagram 
3.18 The Arrangement of the Climax Underground Facilities

at the $1400 \mathrm{ft}$ Level ..................................... 35

3.19 Climax Canister and Heater Drifts Showing Typical

Instrumentation Placement

3.20 A Cross-Section of a Typical Climax Fuel Storage Well

Showing Near-Field Thermocouples

4.1 Thermal History of Fuel Assembly B02

4.2 Thermal History of Fuel Assembly B03

4.3 Thermal History of Fuel Assembly B41

4.4 Thermal History of Fuel Assembly B43

4.5 Thermal History of Fuel Assembly D01

4.6 Thermal History of Fuel Assembly D04

4.7 Thermal History of Fuel Assembly D06

4.8 Thermal History of Fuel Assembly D09

4.9 Thermal History of Fuel Assembly D15

4.10 Thermal History of Fuel Assembly D16

4.11 Thermal History of Fuel Assembly D18

4.12 Thermal History of Fuel Assembly D22

4.13 Thermal History of Fuel Assembly D34

4.14 Thermal History of Fuel Assembly D35

4.15 Thermal History of Fuel Assembly D40

4.16 Thermal History of Fuel Assembly D46

4.17 Thermal History of Fuel Assembly D47

4.18 Fuel Cladding Temperatures for Fuel Assembly B02

Dry Storage Tests at EMAD .............................

5.1 Summary of Krypton-85 in Canister Gas for Breached and Unbreached Fuel Assemblies

B.1 Decay Heat Curve for Fuel Assemblies B02, B03, B41, and B43 ...... B.3 
B.2 Decay Heat Curve for Fuel Assemblies D01, D04, D06, D35, D40,

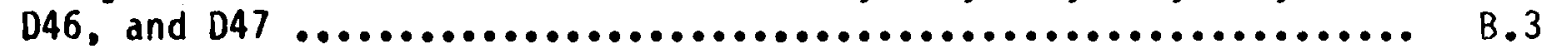

B.3 Decay Heat Curve for Fuel Assemblies D09, D16, D18, and D34 ...... B.4

B.4 Decay Heat Curve for Fuel Assembly 022 ....................... B.4 


\section{TABLES}

2.1 Characteristics of the Turkey Point Fuel Assemblies Used in Spent Fuel Tests

2.2 Irradiation History of Spent Fuel Used in Dry Storage Testing ..... 6

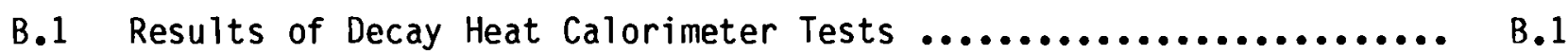

B.2 Analysis of Calorimeter Water for Contamination .............. B.2

D.1 Inter Rod Gas Pressure and Analyses ......................... D.1

E.1 Summary of Gas Sample Integrity Monitoring Results .............. E.1

E.2 Results of Analysis of Fuel Assembly B02 Canister Gas Samples from FTT

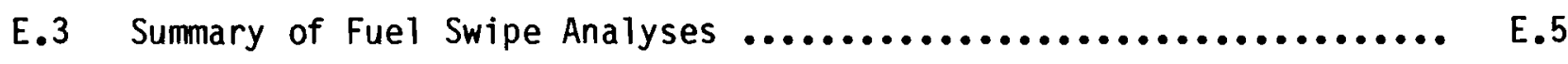

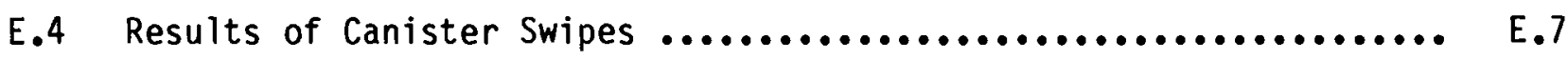




\section{ABBREVIATIONS AND ACRONYMS}

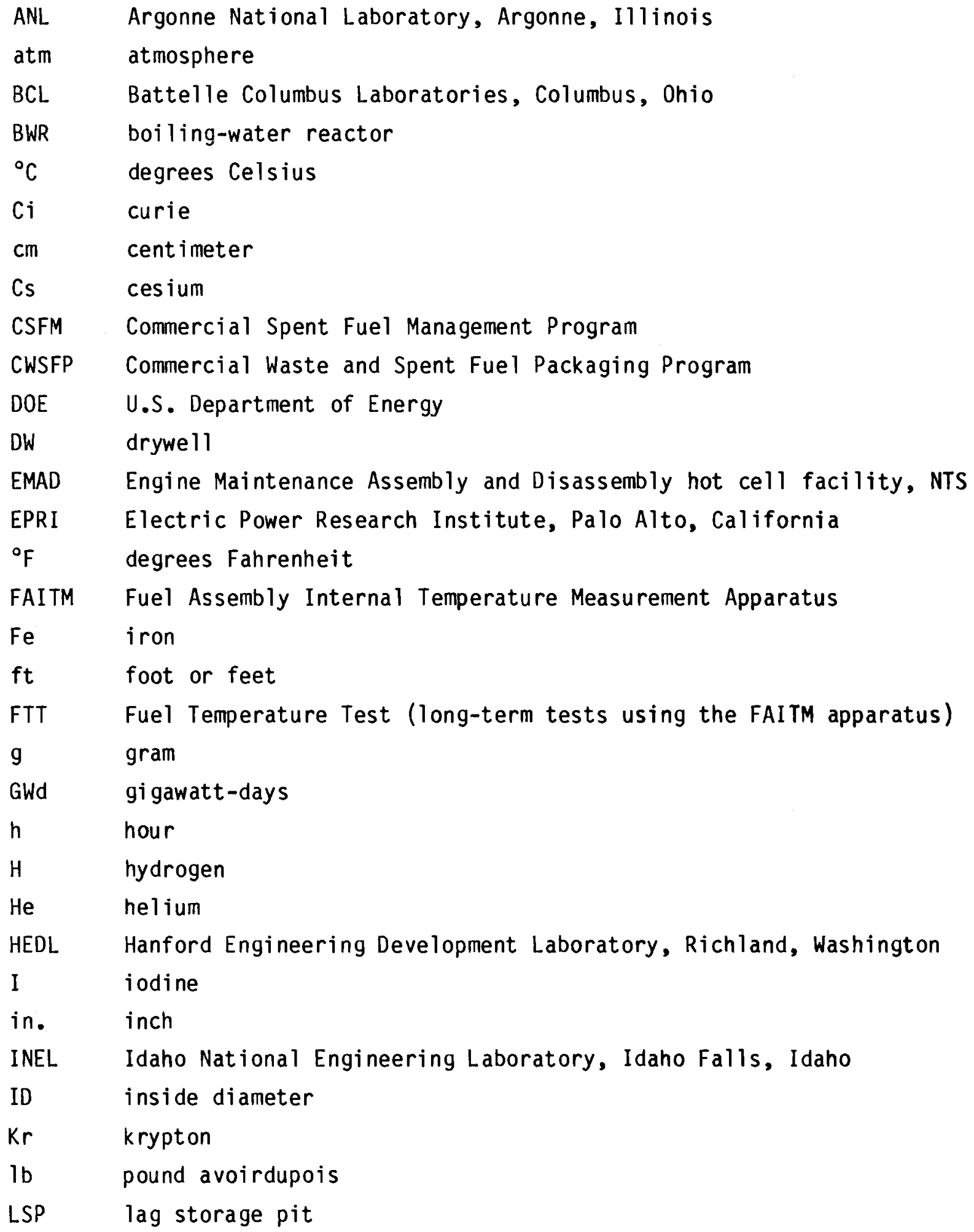




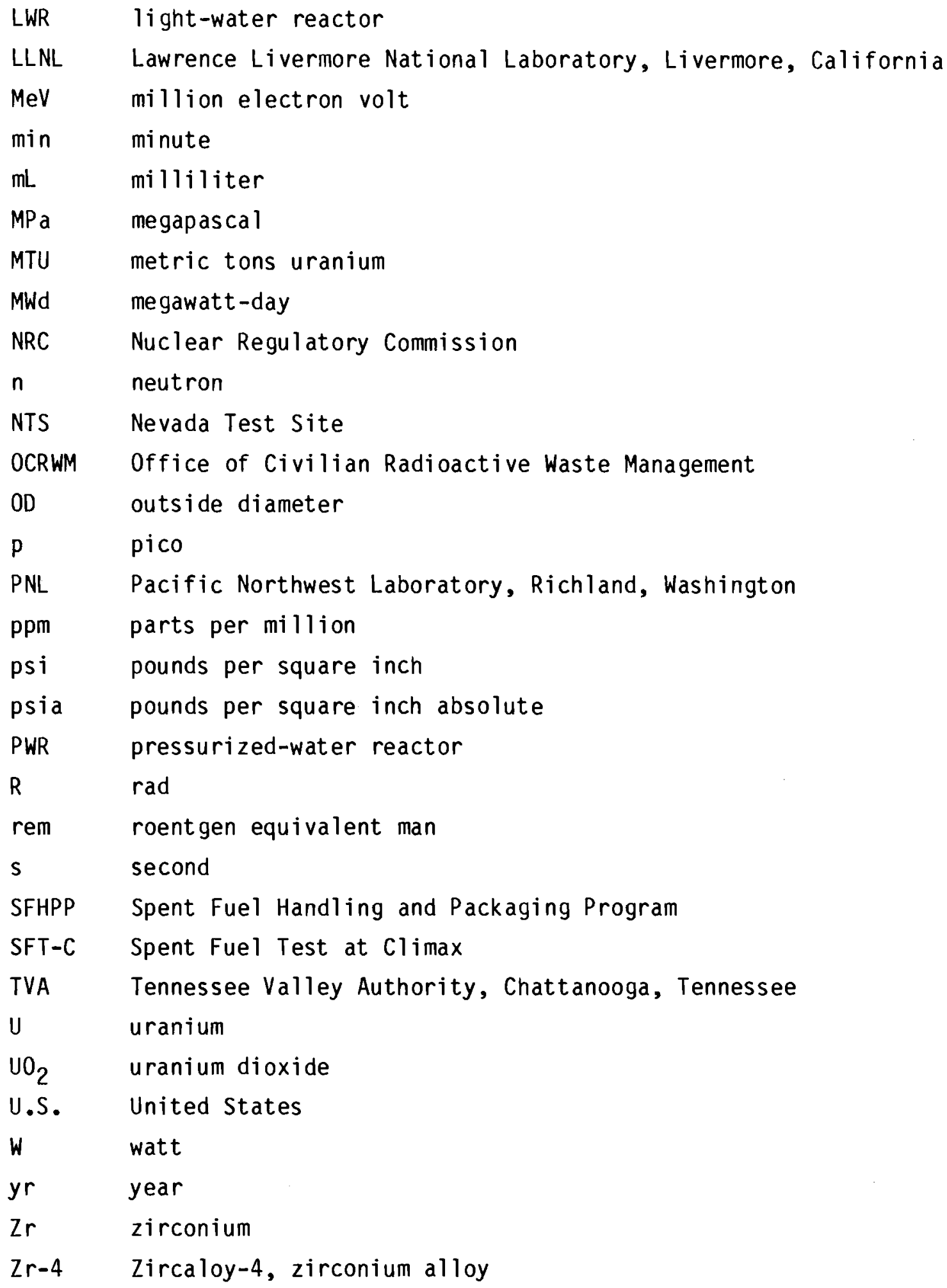


ASSESSMENT OF THE INTEGRITY OF SPENT FUEL ASSEMBLIES

USED IN DRY STORAGE DEMONSTRATIONS AT THE NEVADA TEST SITE

\subsection{INTRODUCTION}

The work described in this report was performed as a part of the Commercial Spent Fuel Management (CSFM) Program sponsored by the Department of Energy's (DOE) Office of Civilian Radioactive Waste Management (OCRWM). The objectives of the CSFM Program are 1) to encourage and expedite the implementation of existing and new spent fuel storage technologies, 2) to accelerate the availability of dry storage and rod consolidation technologies through licensed cooperative demonstrations at reactor sites and unlicensed testing in federal facilities, and 3) to provide the planning for a federal capability to store up to 1900 MT of spent fuel for those utilities that the U.S. Nuclear Regulatory Commission (NRC) determines cannot reasonably provide increased at-reactor storage when it is needed.

This report documents an assessment of the integrity of spent fuel that was used in unlicensed demonstration testing of dry storage performed by Westinghouse Electric Corporation and Lawrence Livermore National Laboratory (LLNL) in the federal facilities at the Nevada Test Site (NTS). The spent fuel was used in DOE's Spent Fuel Handling and Packaging Program (SFHPP), the Commercial Waste and Spent Fuel Packaging Program (CWSFP), and the Spent Fuel Test at Climax (SFT-C) Program.

The fuel assemblies studied in this report were subjected to all aspects of dry storage including the following:

- pre-test shipping

- characterization

- lag storage (vault)

- decay heat measurement

- encapsulation (welded and unwelded)

- emplacement

- storage 
- monitoring

- retrieval

- decapsulation

- inspection

- fuel assembly and rod testing

- post-test shipping.

The histories of these fuel assemblies and experiences in handling and storage as described in this report should be of benefit in planning and evaluating other interim storage, vault storage, monitored retrievable storage, and repository disposal activities.

\subsection{BACKGROUND}

Dry storage is an important option for interim storage of spent fuel because of its low initial costs, low maintenance requirements, and overall safety. However, one concern is that the fuel to be stored may contain defects that could cause a cladding breach during subsequent handing or during storage. Fission products released from the breached fuel may escape from the encapsulation structures or from the encapsulation facilities themselves to the environment through defects. Consequently, a program was undertaken by DOE to 1) develop and test a means of encapsulating typical spent fuel assemblies and 2) establish the feasibility of one or more concepts for interim dry storage of the encapsulated assemblies.

For this program, tests were conducted by Westinghouse Electric Corporation in the Engine Maintenance and Disassembly (EMAD) shielded facilities at the NTS on 17 spent fuel assemblies from the Turkey Point Reactor. These tests included 1) drywell testing, 2) concrete silo testing, 3) air-cooled vault testing, and 4) calibrations in the FAITM apparatus.

The objective of the drywell and concrete silo tests was to confirm, by actual testing, that commercial spent fuel could be passively stored in nearsurface drywells and in an above-ground concrete silo at the NTS. The objective of the air-cooled vault test was to provide temperature and flow data under normal operating conditions and simulated accident conditions to verify that spent fuel assemblies with a heat generation rate of $2.0 \mathrm{~kW}$ could be 
stored temporarily or for long periods in the EMAD lag storage pit (an aircooled vault). The objective of the fuel assembly internal temperature meas urement tests was to obtain data and experience with storing spent fuel in the temperature range between 300 and $570^{\circ} \mathrm{F}\left(150\right.$ and $\left.300^{\circ} \mathrm{C}\right)$ under simulated dry storage cell conditions. Demonstration tests were also performed by the LLNL on retrievable storage of fuel assemblies in drywells located in a granite mine at the NTS Climax site. The EMAD facility was used for the encapsulation and temporary storage of 13 spent Turkey Point fuel assemblies used in the Climax tests. These 13 fuel assemblies were also used in the drywell, air-cooled vault, and internal measurement testing at EMAD.

Before testing, seven selected fuel assemblies were subjected to nondestructive examination at Battelle-Columbus Laboratories (BCL) hot cells to characterize their integrity. Also, five fuel rods from each of two fuel assemblies were destructively examined to further characterize the spent fuel. During storage testing, the temperatures of the spent fuel and surrounding structures were measured to define the conditions of storage. Furthermore, radioactive species in the storage gas and on the fuel and surrounding surfaces was extensively monitored to determine the integrity of the fuel during handling and storage. Following testing, the spent fuel assemblies were subjected to a final visual examination at the EMAD facility and were shipped to the Idaho Nuclear Engineering Laboratory (INEL) for further storage under dry conditions. The 17 assemblies are stored in a concrete silo in flowing nitrogen.

In a related program, another Turkey Point fuel assembly (B17) was characterized at $B C L$ by destructive and nondestructive methods. Dry storage tests were performed at $B C L$ and Argonne National Laboratory (ANL) on individual fuel rods and rod segments.

\subsection{OBJECTIVE OF PRESENT STUDY}

The study discussed in this report was performed by Pacific Northwest Laboratory (PNL) to: 1) assess and document the integrity of the 17 Turkey 
Point spent fuel assemblies during the dry storage demonstrations at NTS and 2) document the suitability of the dry storage technologies and fuel handling procedures used in these demonstrations.

\subsection{SCOPE AND ORGANIZATION OF REPORT}

In this report, summaries and assessments are presented from the following aspects of the dry storage tests and demonstrations at NTS: 1) the events and experience, 2) the thermal histories, 3) the pre- and post-examination data, and 4) the integrity monitoring data for the 17 Turkey Point spent fuel assemblies. Also summarized are the terminal condition of the EMAD storage and handling facilities and the "lessons learned" as a result of storage and handling of these fuel assemblies.

Only summarized or selected typical data are presented here. Data reported elsewhere are included by reference, and only the principal results or conclusions pertinent to the present study are given. Appendices provide detailed handling histories of the fuel assemblies, calorimeter data, predictions of peak fuel clad temperatures, fission gas analysis results, and a summary of gas sample integrity monitoring results. 


\subsection{SPENT FUEL OESCRIPTION}

The spent fuel assemblies were discharged from the Turkey Point Unit 3 Reactor, which is operated by Florida Power and Light. Turkey Point Unit 3 is a pressurized-water reactor (PWR) manufactured by Westinghouse Electric Corp. The general characteristics of the fuel assemblies are given in Table 2.1.

TABLE 2.1. Characteristics of the Turkey Point Fuel Assemblies Used in Spent Fuel Tests

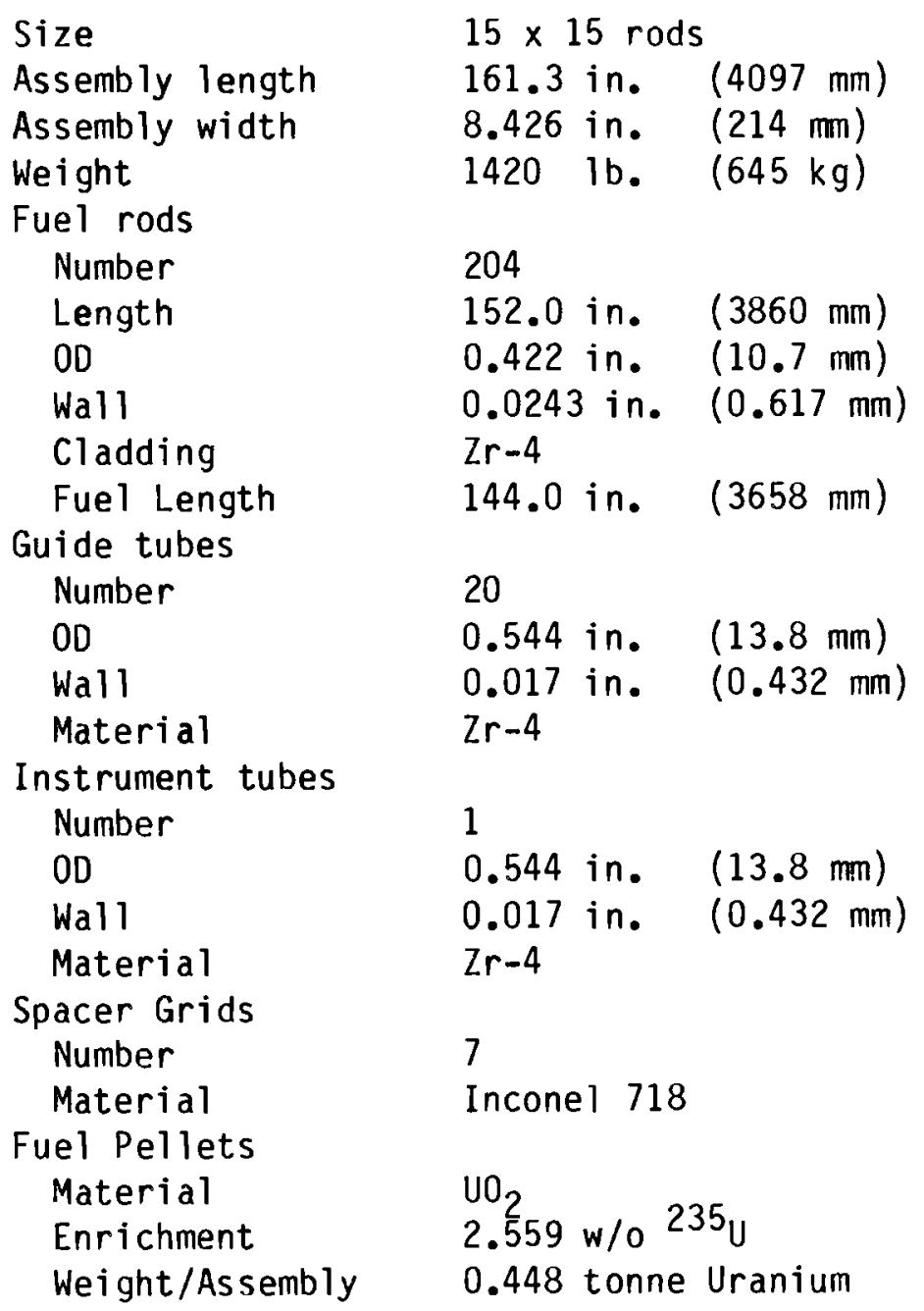


A total of 18 spent fuel assemblies were included in the test program, serial numbers B02, B03, B17, B41, B43, D01, D04, D06, D09, D15, D16, D18, D22, $D 34, D 35, D 40, D 46$, and D47. One fuel assembly, B17, was examined by both nondestructive and destructive methods at $\mathrm{BCL}$ and remained there for dry storage testing of individual rods. The dates of irradiation and the burnup experienced by these assemblies are summarized in Table 2.2. Following discharge from the reactor, the fuel assemblies were stored in the spent fuel pool at Turkey Point Unit 3 until they were shipped in casks to the EMAD facility. The dates of arrival of these assemblies at EMAD are also provided in Table 2.2. The predicted and measured decay heat generation for these fuel assemblies for the period between 1978 and 1983 are presented in Appendix B.

\section{TABLE 2.2. Irradiation History of Spent Fuel Used in Dry Storage Testing}

\begin{tabular}{|c|c|c|c|c|}
\hline Serial & Irradia & $n$ Dates & Received & Burnup \\
\hline Number & Start & End & & \\
\hline $\mathrm{B} 02^{(\mathrm{a})}$ & $1 / 12 / 72$ & $10 / 25 / 75$ & $12 / 04 / 78$ & 25,665 \\
\hline $\mathrm{B} 03^{(a)}$ & " & $"$ & $1 / 10 / 79$ & $"$ \\
\hline$B 41(a)$ & " & $"$ & $1 / 23 / 79$ & $"$ \\
\hline$B 43^{(a)}$ & $"$ & $"$ & $2 / 06 / 79$ & 25,596 \\
\hline$D 01(a)$ & $12 / 12 / 74$ & $11 / 19 / 77$ & $12 / 12 / 79$ & 28,430 \\
\hline $\mathrm{DO} 4(\mathrm{a})$ & $"$ & $"$ & $12 / 11 / 79$ & $"$ \\
\hline$D 06^{(a)}$ & $"$ & $"$ & $11 / 30 / 79$ & $"$ \\
\hline D09 & $"$ & $"$ & $10 / 09 / 79$ & 27,863 \\
\hline D15 & " & $"$ & $11 / 25 / 79$ & 28,430 \\
\hline D16 & $"$ & $"$ & $10 / 22 / 79$ & 27,863 \\
\hline D18 & $"$ & $"$ & $10 / 20 / 79$ & $"$ \\
\hline D22 & $"$ & $"$ & $11 / 12 / 79$ & 26,435 \\
\hline D34 & " & $"$ & $11 / 01 / 79$ & 27,863 \\
\hline D35 & " & $"$ & $11 / 15 / 79$ & 28,430 \\
\hline D40 & $"$ & $"$ & $9 / 21 / 79$ & $"$ \\
\hline D46 & $"$ & $"$ & $9 / 24 / 79$ & $"$ \\
\hline D47 & $"$ & $"$ & $10 / 01 / 79$ & $"$ \\
\hline
\end{tabular}

(a) Assemblies characterized at BCL before shipment to EMAD. 


\subsection{HISTORY OF SPENT FUEL DURING DRY STORAGE DEMONSTRATIONS}

The 18 fuel assemblies described in Section 2.0 were shipped either directly or via BCL to EMAD where eight assemblies underwent pretest characterization (Dobbins 1983). One of the characterized fuel assemblies was used for the single-rod test at $B C L$ and for the rod-segment tests at ANL described in Section 3.4. All of the remaining 17 assemblies were used in the dry storage demonstration tests at NTS. Before shipping or upon arrival at BCL (or both) wet sip testing was performed, and only assembly B41 appeared to contain a breached rod (Davis 1980 and 1981). The results of the pretest characterization are summarized in Section 3.1.

Four assemblies (B02, B03, B41, and B43) were assigned to the SFHPP demonstration Program in 1978. Fuel assembly B02 was installed in Concrete Silo No. 2 for extended residence; fuel assemblies $\mathrm{B} 03$ and $\mathrm{B} 41$ were installed in Drywells 5 and 3 , respectively, for the Phase I Isolated Drywell Test; and fuel assembly B43 was used for the Phase II Fuel Assembly Internal Temperature Measurement (FAITM) Test. Fuel assemblies B03, B041, and B43 were later installed in Drywells 3, 2, and 1, respectively for the Adjacent Drywell Test. The EMAD dry storage tests are described in Section 3.2.

The 13 assemblies for the Spent Fuel Tests at Climax (SFT-C) Program (D01, D02, D06, D09, D15, D16, D18, D22, D34, D35, D40, D46, and D47) were encapsulated and stored in the EMAD lag storage pit (concrete vault) prior to transport and installation in the SFT-C facility. The SFT-C tests are described in Section 3.3. Two of these assemblies, D22 and D15, were first used in the Phase II Isolated Drywell test and the Phase II FAITM Test prior to transport to SFT-C. Later, assembly B02 was installed in the FAITM test stand for the extended Fuel Temperature Tests (FTT). While in the vault storage pit, the canister containing fuel assembly 022 was instrumented for the Air-Cooled Vault Tests.

The complete histories of these 17 fuel assemblies while at the NTS are summarized in Figure 3.1 and are described in detail in Appendix A. Following the demonstration testing at the NTS, all 17 fuel assemblies were shipped by cask to INEL for subsequent storage. 


\subsection{PRETEST CHARACTERIZATION}

Nondestructive, destructive, or both types of examination were performed on assemblies B02, B03, B17, B41, B43 D01, D04, and D06 at BCL under the direction of the Hanford Engineering Development Laboratory (HEDL). The purpose of these examinations was to establish the condition of the fuel prior to demonstration testing.

\subsubsection{Examination of Fuel Assemblies B02, B03, B17, B41 and B43}

The nondestructive examination of these fuel assemblies was reported by Davis (1980); the destructive examination of rods G7, G9, J8, I9, and H6 of fuel assembly B17 was reported by Davis and Pasupati (1981). The nondestructive examinations included sip testing for breached rods, visual examination, neutron and gamma flux determinations, and dimensional measurements. The sip test results suggested that assembly $B 41$ contained one or more rods with breached cladding; the other assemblies were of sound integrity and unbreached.

According to Davis (1980), visual examination revealed three general types of surface deposits: 1) a dark adherent crud layer at the bottom (coolant inlet end), 2) black spalling layers in the middle, and 3) a spotty gray, ioose powdery coating with dark crud or oxide underneath towards the top. In subsequent visual examinations by PNL, however, little evidence of crud or oxide spallation could be observed. Photographs of the top, middle, and bottom regions of fuel assemblies $\mathrm{B} 02$ show these deposits as they appeared following testing (Figures 3.2 to 3.4). Rod lengths varied from 152.395 to $152.707 \mathrm{in}$. Rod bow measurements ranged from $0.022 \mathrm{in}$. to $0.040 \mathrm{in}$. Average diameters ranged from 0.4187 to $0.4198 \mathrm{in.}$, and maximum ovality was $0.0066 \mathrm{in}$. Extensive ridging from pellet/cladding interactions was evident on all rods. Gamma scan results showed no cesium peaking and no pellet gaps greater than 0.025 in. Pretest eddy current inspection of five rods from assembly $\mathrm{B} 02$ indicated that incipient defects were present. No other unusual areas, other than ridging and possible fuel/cladding bonding, were seen in the eddy current tests.

The rods removed from most fuel assemblies were replaced following the nondestructive examination. However, the five rods from assembly B17 were given further destructive examination including fission gas analysis, rod void 
- Gas Sample

S Swipe Calorimetry

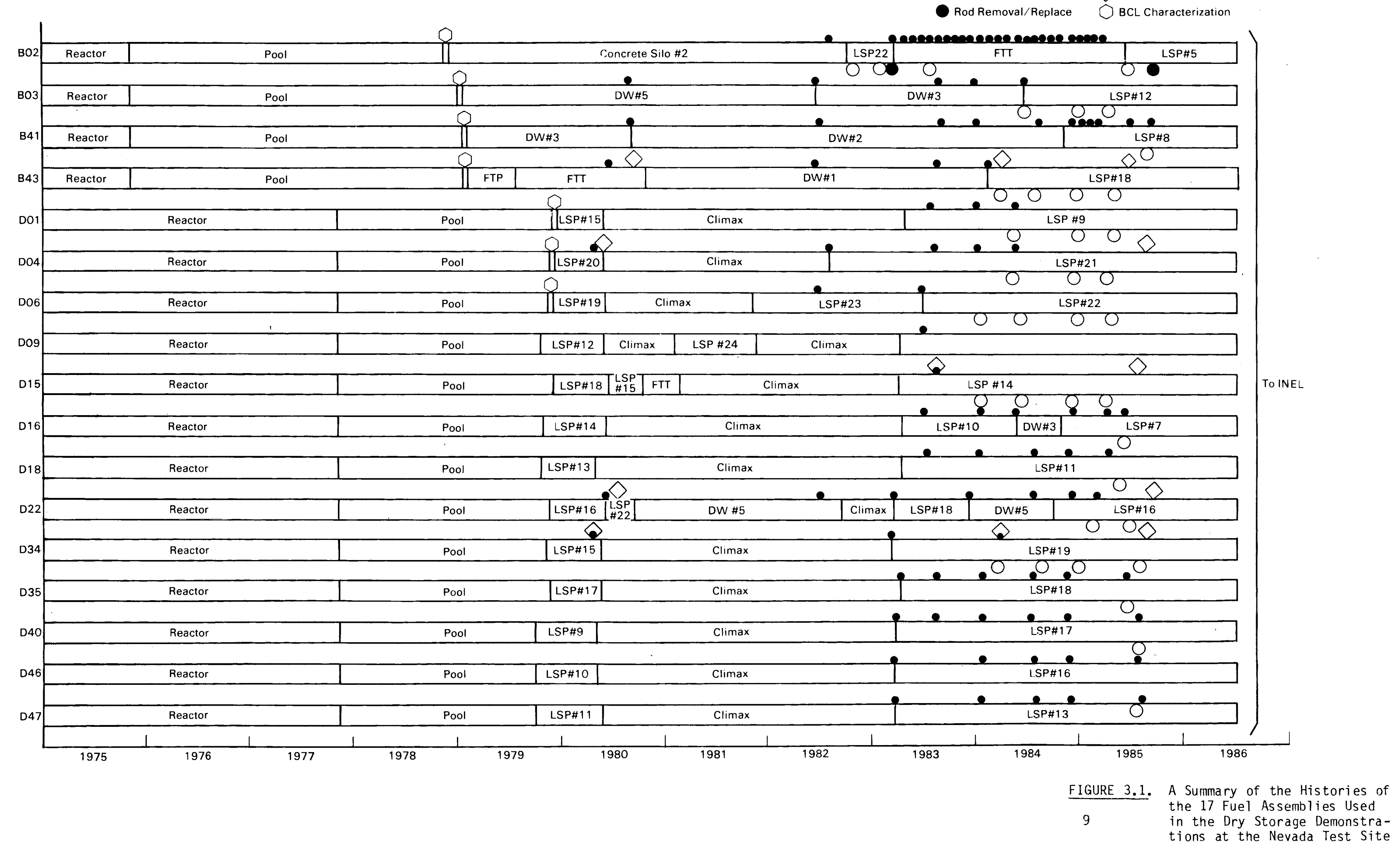





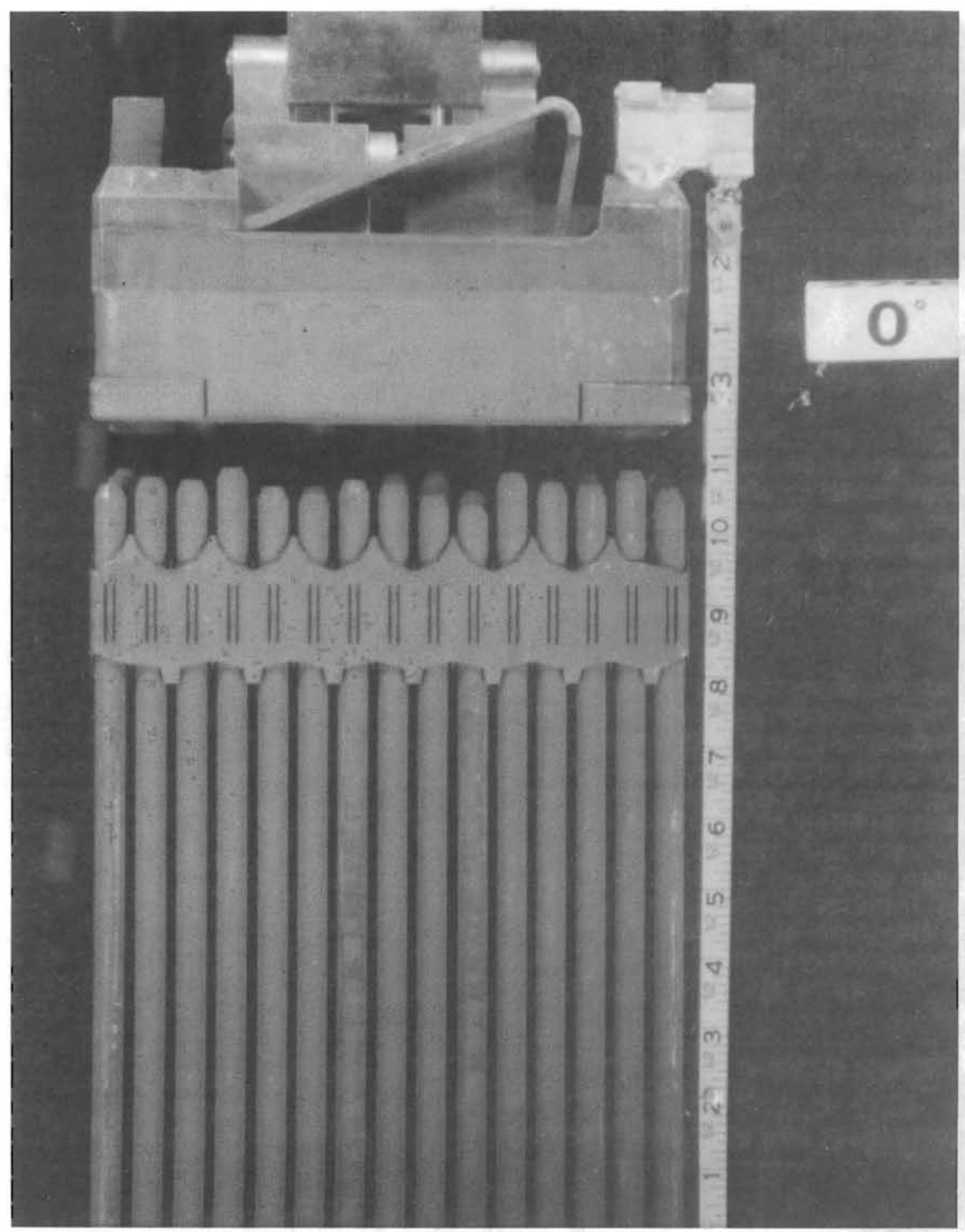

FIGURE 3.2. Post-Test Photograph of Top Section of Fuel Assembly B02 


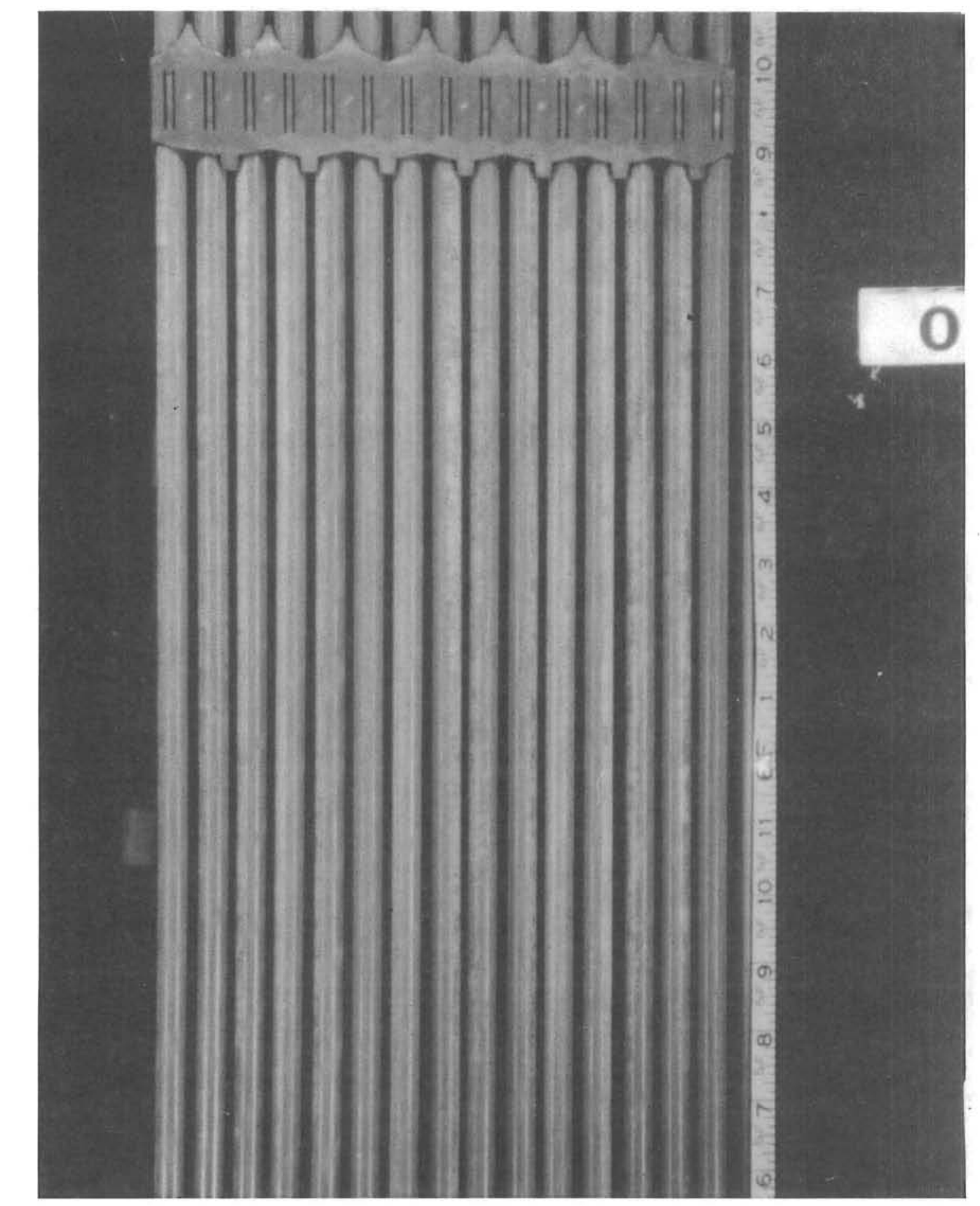

FIGURE 3.3. Post-Test Photograph of Center Section of B02 


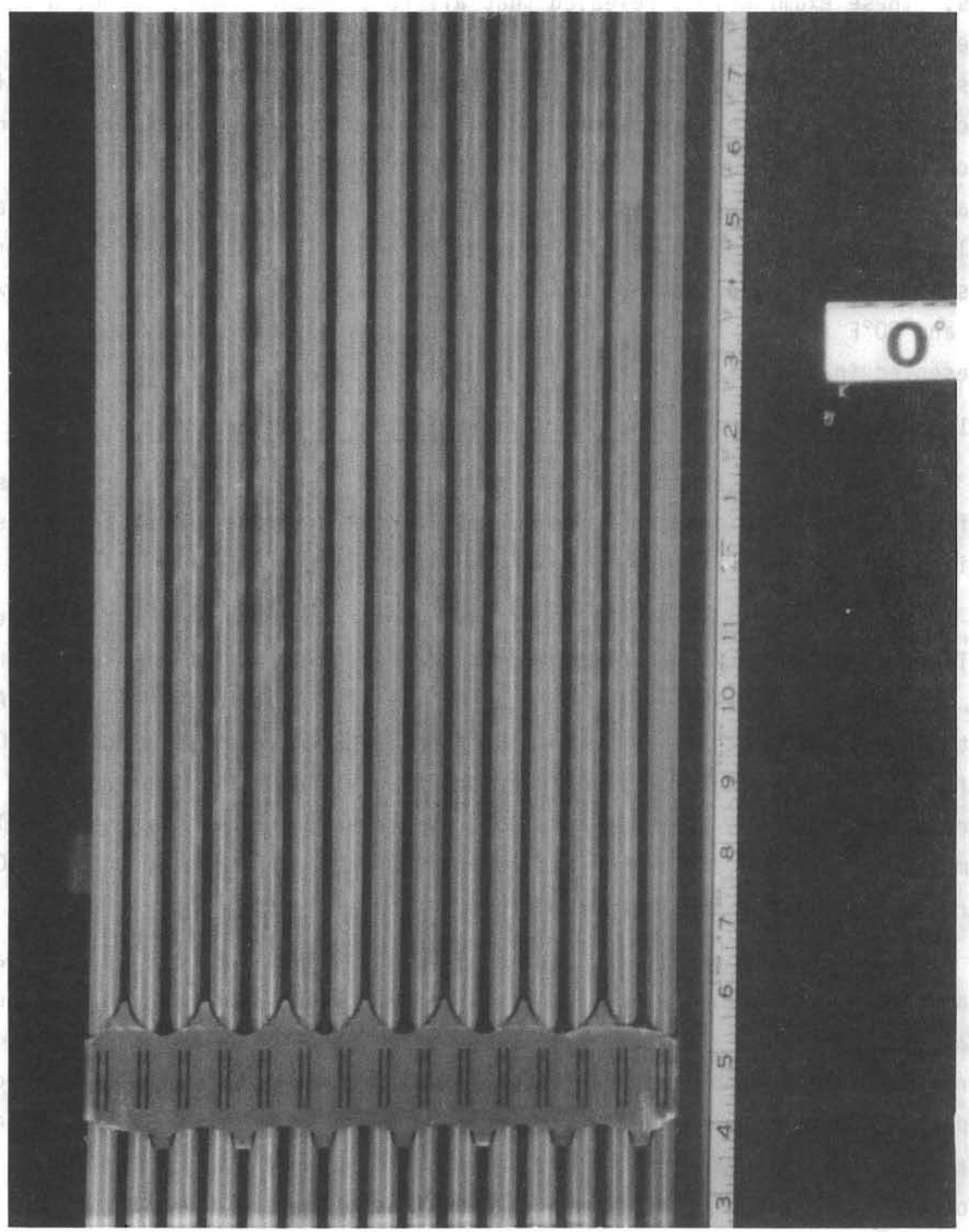

FIGURE 3.4. Post-Test Photograph of Bottom Section of B02 
measurement, metallographic examination, fuel burnup analysis, cladding hydrogen content analysis, autoradiography, and shielded electron microprobe analysis. These examinations revealed that all rods examined were sound, with an average burnup of 27 GWD/MTU and a $0.3 \%$ fission-gas release. All samples were observed to have some fuel/cladding interaction that penetrated the cladding from 5 to $40 \mu \mathrm{m}$. The reaction products (a compound of fuel, cladding, and fission products) appeared as localized globules and semi-continuous layers. The cladding hydrogen content varied from an average concentration of $36 \mathrm{ppm}$ at the inlet end of the rods to up to $77 \mathrm{ppm}$ near the outlet end. The internal rod gas pressures ranged from 331 to 401 psia at measurement temperatures between 77 and $80^{\circ} \mathrm{F}\left(25\right.$ and $\left.27^{\circ} \mathrm{C}\right)$. The results of the analyses of this gas are presented in Appendix D.

\subsubsection{Examinations of Spent Fuel Assemblies D01, D04, and D06}

The spent fuel assemblies destined for the SFT-C Program were sip tested before they were shipped from the Turkey Point Reactor. None of these assemblies gave any indications of leaking fuel rods.

Three fuel assemblies (D01, D04, and D06) from those obtained for the SFT-C program were given extensive destructive and nondestructive examination at BCL, and the results were reported by Davis (1981) and Atkin (1981). A total of 38 fuel rods were removed, 20 from D01 and 9 each from D04 and D06. Fifteen rods were characterized nondestructively and reinserted, 7,4 and 4 rods in assemblies D01, D04 and D06, respectively. Five stainless steel dummy rods were placed in each assembly. The remaining missing rods in D01 were replaced with uncharacterized rods.

Nondestructive tests performed on individual fuel rods included visual examination, dimensional measurements, gamma activity scan, and eddy current analysis. The three fuel assemblies were found to be sound. Structural components of the assembly were uniformly oxidized, and none of the grid spacers appeared cocked or misaligned. The peripheral rods on each assembly had a dark black oxide layer near the bottom, changing to a light gray at the top. Blotchy combinations of black and gray were seen in the middle regions of the rods. The fuel assembly weights averaged 1459 lb., the lengths $153.65 \mathrm{in.}$, and the widths $8.312 \mathrm{in}$. The total neutron flux and neutron energy measured at the 
fuel midplane were $1.06 \times 10^{4} \mathrm{n} / \mathrm{cm}^{2} / \mathrm{s}$ and $1.4 \mathrm{MeV}$, respectively. The average weight and length of the examined individual rods were $6.821 \mathrm{~b}$. and 152.561 in., respectively. Nearly all rods exhibited cladding ovality localized in the mid-region of the rod between fuel pellets and ranged between 0.005 and $0.010 \mathrm{in}$. Large ridges measuring $0.003 \mathrm{in}$. were found, but no large bulges, blisters, or scars were observed. Eddy current data revealed several anomalies on the cladding internal surface; however, it was not possible to interpret these anomalies.

Destructive examinations were performed on five individual rods, three from D01 and two from D04. These examinations included fission gas collection and analysis, burnup analysis, hydrogen analysis, and metallographic analysis. The results were generally consistent with the typical results of similar examinations of PWR fuels of equal burnup. The maximum oxide thickness on the surface of the rods ranged from 110 to 620 microinches $\left(42\right.$ to $236 \mathrm{mg} / \mathrm{dm}^{2}$ or 3 to $16 \mu \mathrm{m}$ ) and was observed to increase with the distance from the bottom of the rod. The hydrogen concentrations in the cladding increased from the inlet to the outlet end and ranged between 40 and 90 ppm. Hydride platelet distribution was circumferential, with coarser platelets occurring at the top of the rod. Fuel/cladding chemical interaction was evident at many locations. The average fission gas release was $0.021 \%$ and was typical for fuels with similar operating histories. The internal gas pressure of the rods ranged from 496 to 523 psia at $77^{\circ} \mathrm{F}\left(25^{\circ} \mathrm{C}\right)$. The analysis of this gas is described in Appendix D. The fuel displayed nonuniform distribution of grain size and porosity. The radial distribution of grain size indicated some grain growth toward the center, with larger distributions occurring nearer the top of the rod.

\subsection{HANDLING AND TESTING AT EMAD}

The 17 spent fuel assemblies were each encapsulated in a stainless steel canister upon arrival at the EMAD hot cell facilities. Following encapsulation, the assemblies with "B" prefix serial numbers were used in the EMAD Program drywell, concrete silo, and FAITM tests. The 13 remaining assemblies with "D" prefix serial numbers were stored in the lag storage pit (air-cooled 
vault). Eleven of these remaining assemblies were then shipped to the Climax facility for the SFT-C program described in Section 3.3. Both before and after the SFT-C tests, the four assemblies were used for the EMAD air-cooled vault drywe11, and FAITM tests. See Figure 3.1 and Appendix A for specific chronology of testing. The EMAD facilities, encapsulation procedures, and testing were reported in detail by Unterzuber et al. (1982) and are summarized below.

\subsubsection{Encapsulation}

Upon receipt at the EMAD facilities, each fuel assembly was encapsulated in a stainless steel canister shown schematically in Figure 3.5. The canister consisted of a cylindrical body, which housed the spent fuel assembly, and a closure. The body was fabricated from a 154-in. length of 14-in. nominal Type 304 or $304 \mathrm{~L}$ stainless steel pipe $(0.375$-in. wall) with an ellipsoidal end cap and was supplied with an internal stainless steel framework to support the fuel. Welded to the top of the body was a 9-in.-long section of 14-in. pipe with 0.937-in. wall that was threaded to receive the closure. The closure was a flat disk $3.5 \mathrm{in}$. in diameter made from Type 304 stainless steel and threaded to engage in the top of the canister body. A seal lip was provided to allow the seal welding of the closure to the body. A fitting was provided in the closure for helium backfilling and sampling of the canister atmosphere.

Thermocouple channels on the external surfaces of the canister body allowed the placement of six to ten thermocouples in various axial positions along the canister. A shield plug was attached to the canister closure. This shield plug was fabricated from a 13.5-in. length of 16-in.-dia carbon steel pipe filled with concrete. The plug was attached to the canister by means of four pins threaded into a skirt at the bottom of the plug. These pins projected into recesses in the side of the canister body. The shield plug contained tubes that communicated with the thermocouple channels for the insertion of thermocouples to measure canister temperatures.

Typically, a spent fuel assembly was examined remotely by TV camera after removal from the shipping cask. It was then placed in a canister located in the EMAD weld pit, and the closure was installed. The closure seal weld was made and inspected remotely. The canister was then evacuated and backfilled with helium to a pressure of approximately 1 atm and remotely leak checked. 


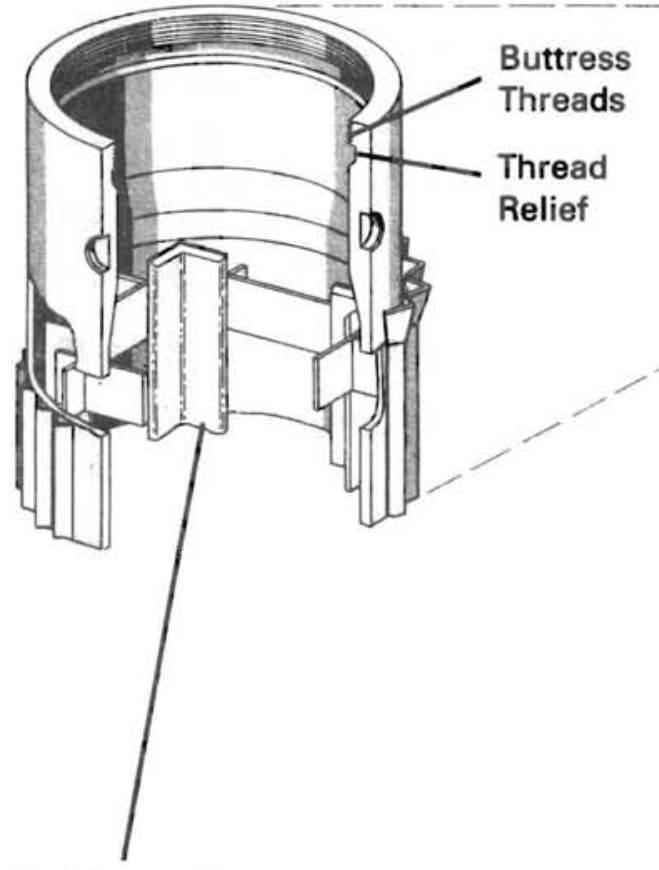

Fuel Assembly

Support Cage

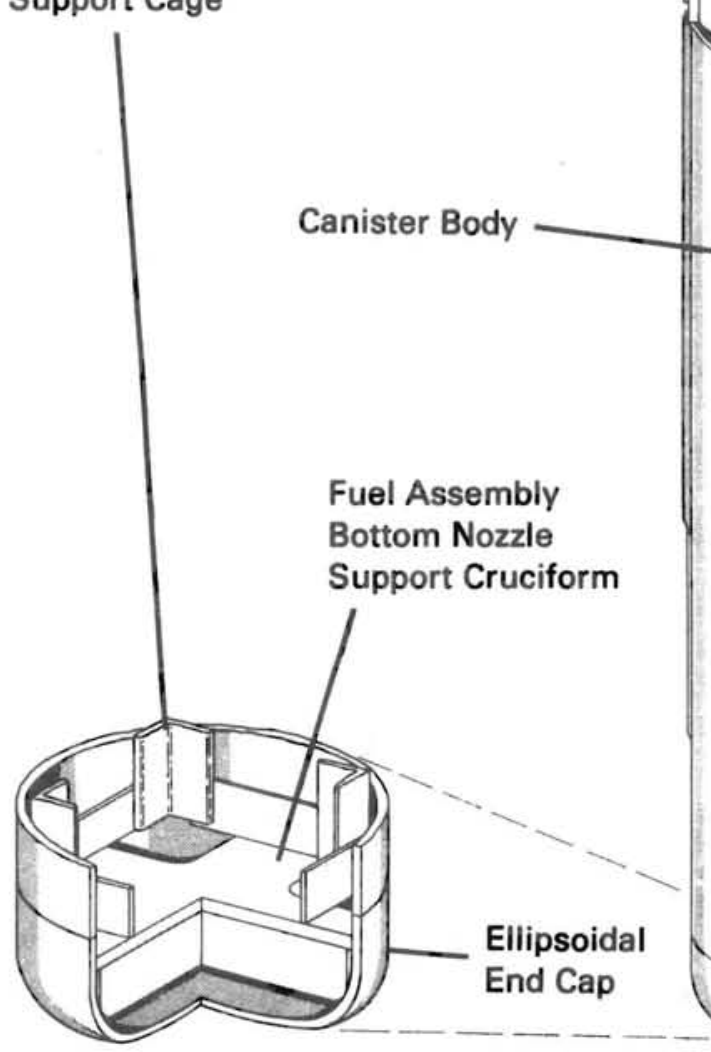

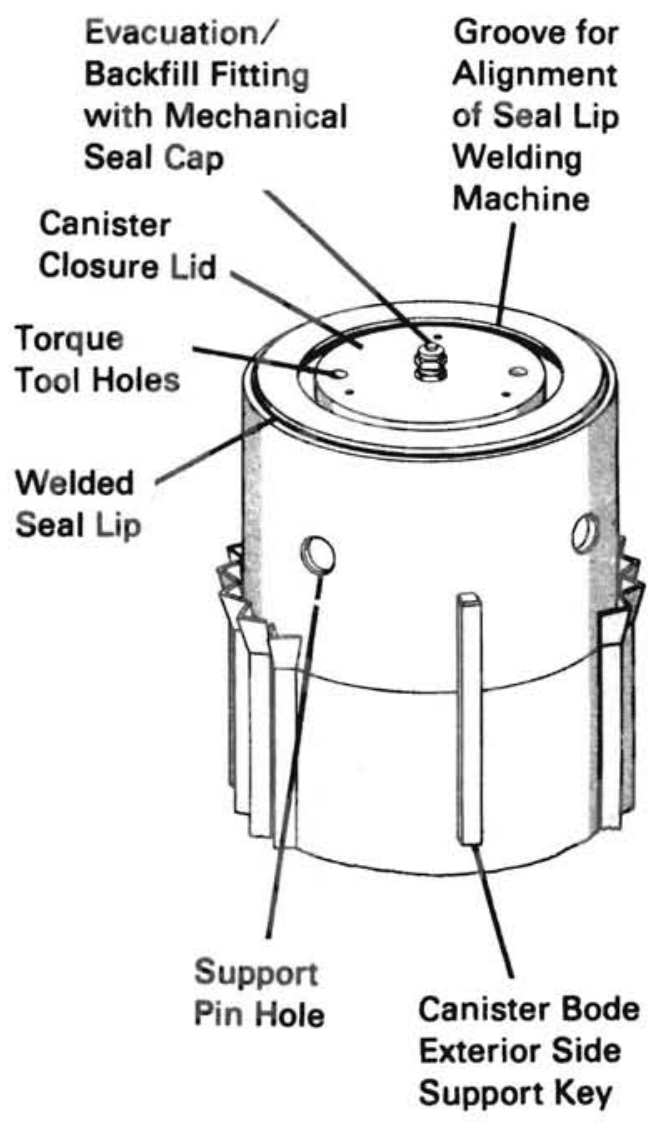

Canister Body External Thermocouple Tubes

PWR Fuel Assembly Spot Welded Angle

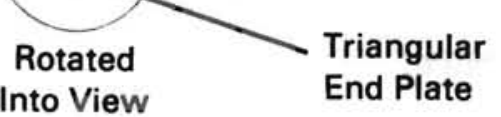

FIGURE 3.5. Typical Canister Used to Encapsulate the Spent Fuel Assemblies 
After the shield plug was attached, the encapsulated assembly was moved to the EMAD survey pit, where surface swipes were remotely performed to check for canister surface contamination. The canister was then moved to the lag storage pit for temporary storage or inserted into the EMAD transfer pit for subsequent transfer by vehicle to a drywell or concrete silo or for shipment to Climax. Complete details on the encapsulation and handling of the spent fuel can be found in Appendix B of Unterzuber et al. (1982).

Measurements of the neutron spectra and exposure rate associated with a typical fuel assembly (D22) in a sealed capsule indicated a neutron flux of $7.55 \times 10^{2} \mathrm{n} / \mathrm{cm}^{2}$-s and neutron exposure of $0.072 \mathrm{rem} / \mathrm{h}$ at $14 \mathrm{in}$. from the canister surface. At $26 \mathrm{in}$. from the surface, the corresponding figures were $4.57 \times 10^{2} \mathrm{n} / \mathrm{cm}^{2}-\mathrm{s}$ and $0.0440 \mathrm{rem} / \mathrm{h}$.

\subsubsection{Drywell Tests}

The objectives of the spent fuel drywell tests were: 1) to verify that spent fuel assemblies can be safely stored in NTS soil, 2) to provide information to calibrate and verify thermal models, and 3) to determine thermal interactions of adjacent drywells. These spent fuel tests were supported by previous tests utilizing electrically heated fuel assemblies to verify that fuel could be tested without damage, verify computer models, and check out the instrumentation system for subsequent fuel tests.

The arrangement of a typical drywell containing an encapsulated fuel assembly is shown in Figure 3.6. A schematic drawing of a drywell showing important dimensions is given in Figure 3.7. The drywell consisted of an 18-in.-0D, 0.375-in.-thick wal1, 17-ft-long liner pipe closed at the bottom and fitted with a 51.5-in. section of 22-in.-0D pipe with a 0.75-in.-thick wa11. The transition between the 18-in. and 22-in. pipe was a welded-in-place ring that supported the shield plug. The liner was placed in a 26-in.-diameter hole bored $23 \mathrm{ft}$ into the soil at EMAD and grouted into place. Nine thermocouple wells were provided around the exterior surface of the liner at various circumferential positions and extended for almost the full length of the liner. Thermocouples were installed in these wells at a depth to align, generally, with corresponding thermocouples on the canister. Four drywells were arranged in a configuration shown in Figure 3.8. Additional instrumentation wells were 


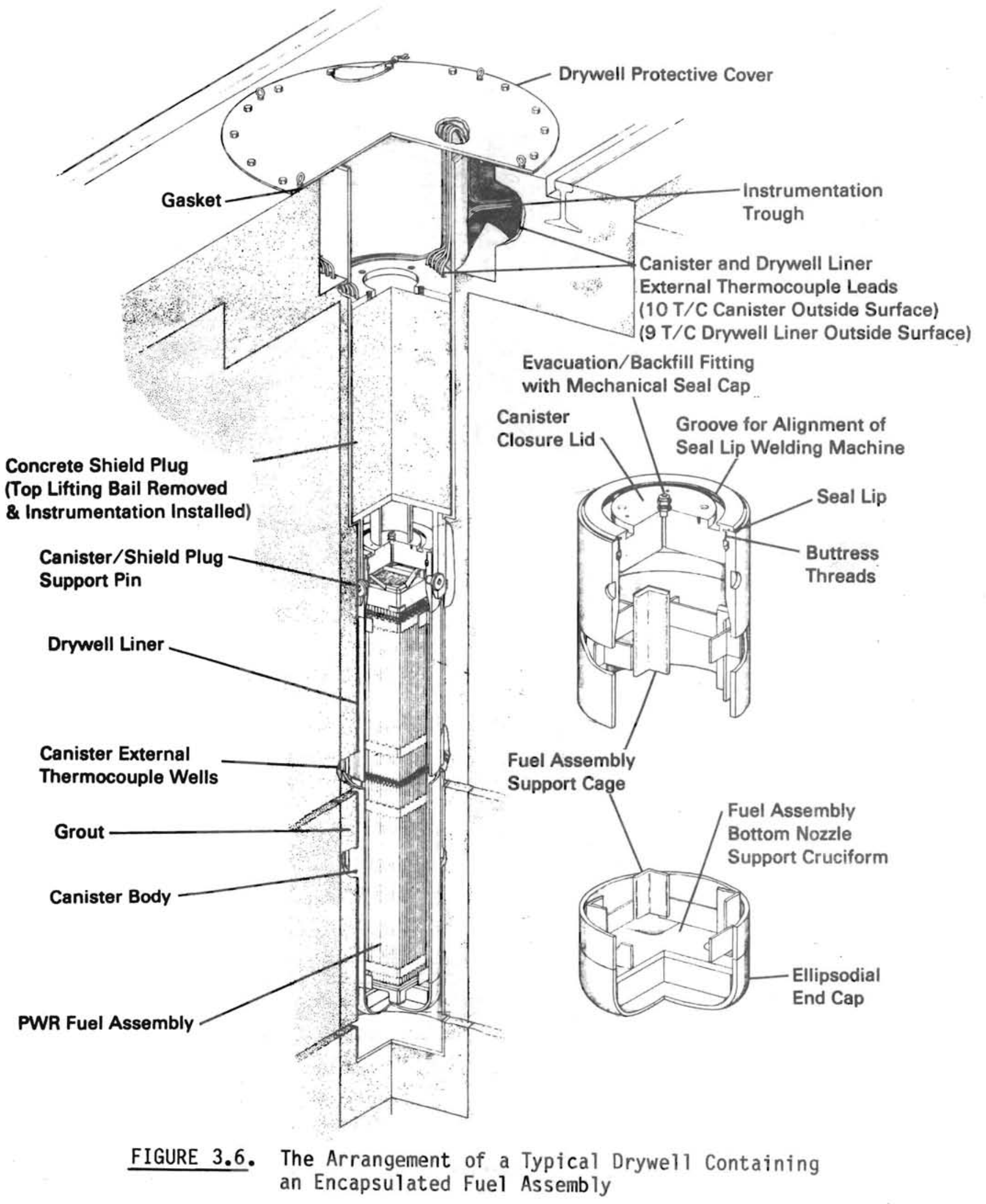




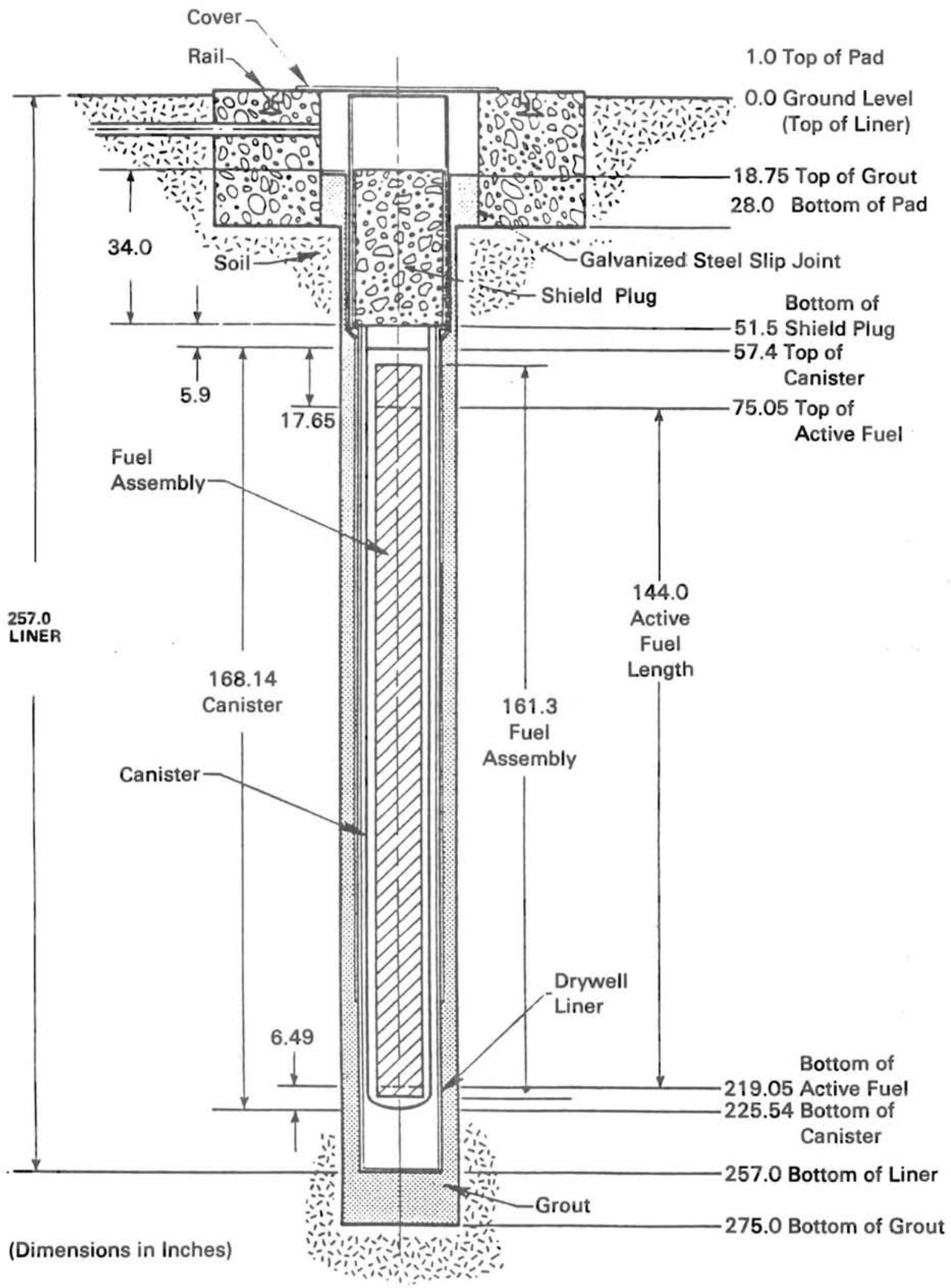

FIGURE 3.7. The Cross-Section View of a Typical Drywell Showing Important Dimensions 


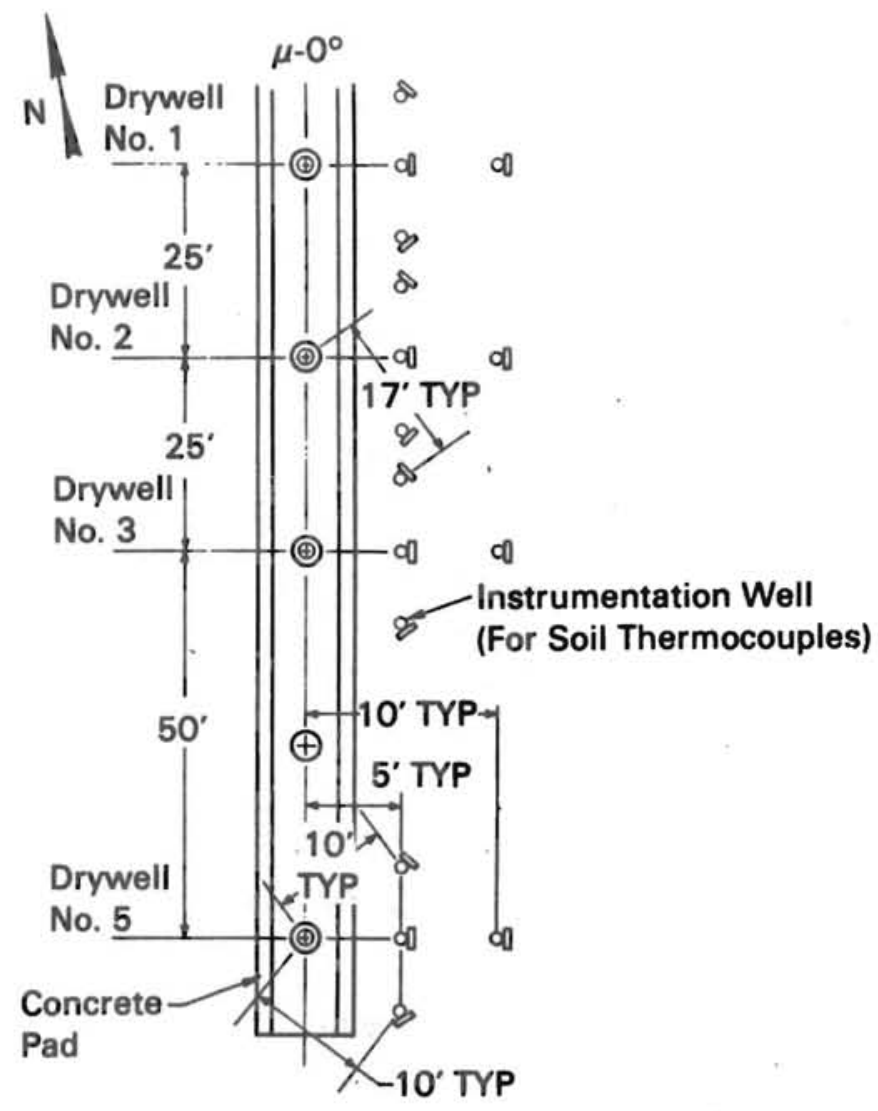

FIGURE 3.8. Arrangement of Drywells Showing Locations of Soil Instrumentation (Dimensions in Feet)

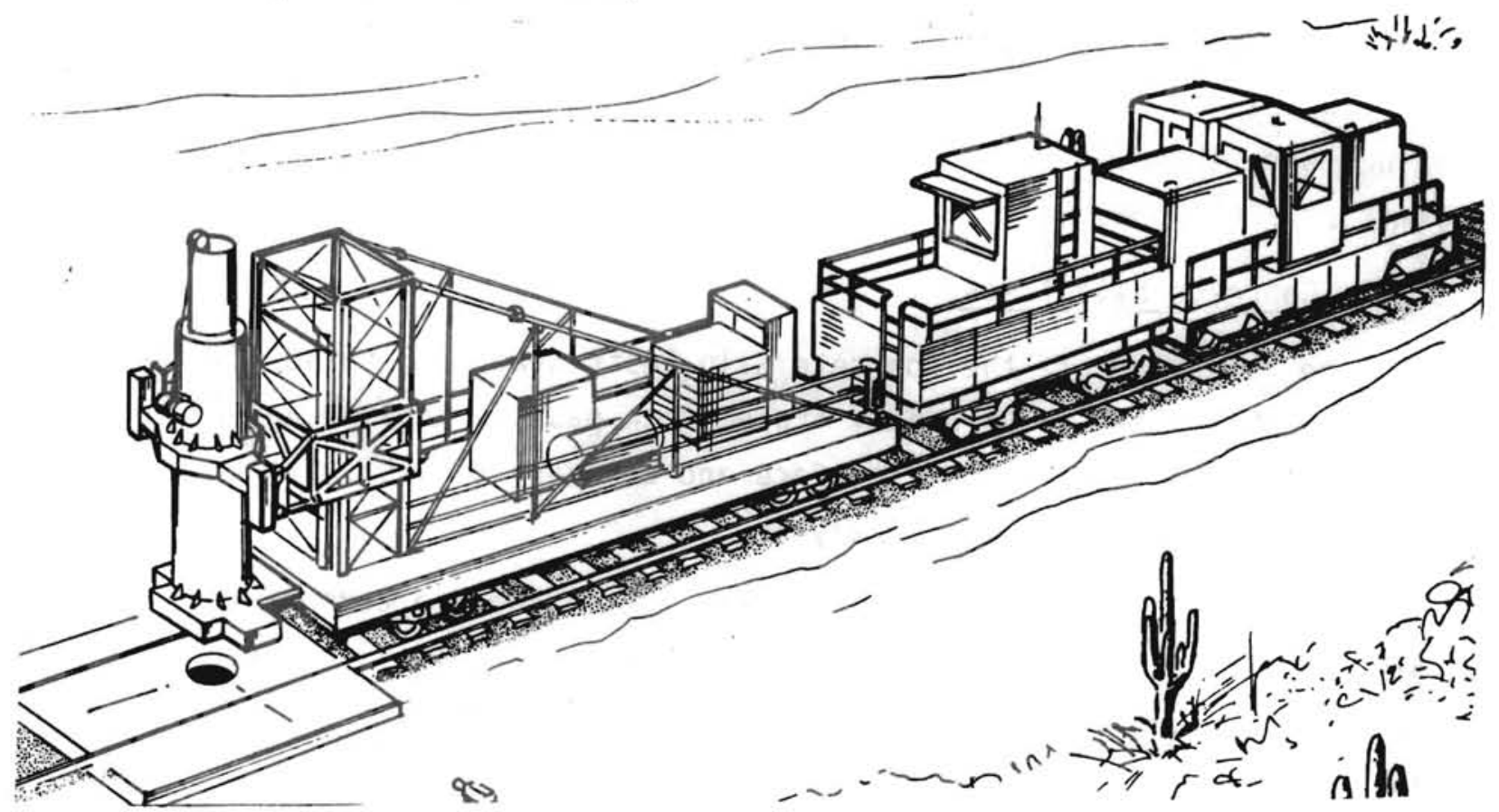

FIGURE 3.9. Fuel Transfer Vehicle and Shield Used to Transport Encapsulated Fuel Assemblies To and From the Drywells 
provided in the soil at the positions shown. The encapsulated fuel was installed into the drywell using a railcar-mounted transfer shield. The transfer vehicle positioned over a drywell is shown in Figure 3.9.

Experiments were performed first with fuel assemblies placed in distant drywells to minimize interactions and then in adjacent drywells to investigate these interactions. Isolated drywell tests were performed with encapsulated assemblies B03 and B41 in drywells 5 and 3, respectively. After about 14 months, the canisters were removed and gas samples revealed that no rod failures had occurred. Later, fuel assembly D22 was installed in position 5. In the adjacent drywell test, fuel assemblies B03, B41, and B43 were placed in drywells 1, 2, and 3, respectively. In both isolated and adjacent drywell tests, temperatures indicated by thermocouples installed on the canister, drywell liner, and soil were continuously monitored; periodically, gas samples were taken to determine the integrity of the encapsulated fuel. The data were presented by Unterzuber et al. (1982) and showed that there was virtually no interaction between the drywells. For decay heat levels of $1.0,1.25$, and $0.63 \mathrm{~kW}$, peak measured canister temperatures were 253, 323, and $199^{\circ} \mathrm{F}(123$, 162 , and $\left.93^{\circ} \mathrm{C}\right)$. Using the results of the relationships developed from the FAITM test data, these temperatures were found to correspond to peak fuel temperatures of 452,364 , and $291^{\circ} \mathrm{F}\left(233,184\right.$, and $\left.144^{\circ} \mathrm{C}\right)$, respectively. These values were observed to be well below the fuel assembly storage temperature limit of $716^{\circ} \mathrm{F}\left(380^{\circ} \mathrm{C}\right)$.

\subsubsection{Concrete Silo Tests}

The objectives of the Concrete Silo Tests were: 1) to verify that spent fuel assemblies can be be safely stored with passive cooling and 2) to determine thermal properties and interface and boundary conditions necessary to calibrate and verify thermal analysis.

The concrete silo used in this test consisted of a carbon steel liner which contained the encapsulated fuel, encased in a locally transportable concrete cylinder, $8 \mathrm{ft} 8 \mathrm{in}$. in diameter and $21 \mathrm{ft}$ high. The concrete silo was placed on a $16 \mathrm{ft} \times 16 \mathrm{ft} \times 9 \mathrm{ft}$ reinforced concrete foundation pad. A drawing of the silo is given in Figure 3.10 . 


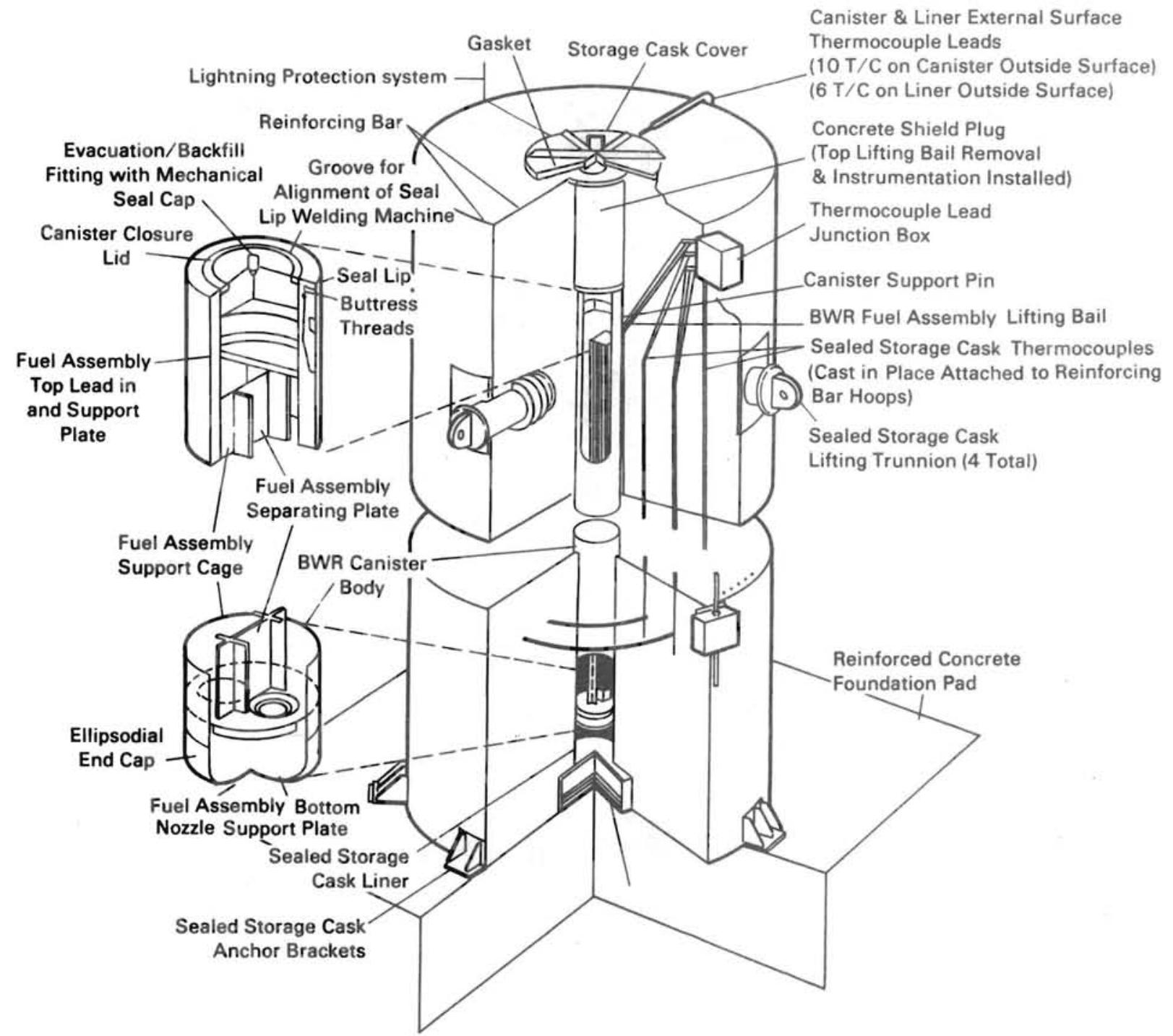

FIGURE 3.10. The Arrangement of the Sealed Storage Cask Used in the Concrete Silo Tests

The liner consisted of a 17-ft-long piece of 18-in. OD carbon steel pipe with a 0.375-in. wall. A 34-in.-long piece of 22-in.-dia steel pipe with a 0.5-in. wall was welded to the upper end to accommodate the shield plug. The lower end of the liner was closed by a shielding assembly consisting of $7.5 \mathrm{in}$. of steel and $6 \mathrm{in}$. of concrete to limit radiation during transportation of the loaded silo. The liner was then encased in reinforced concrete. A schematic drawing of a silo showing dimensions is given in Figure 3.11. A total of 18 thermocouples were attached to the liners or placed on wells adjacent to the 


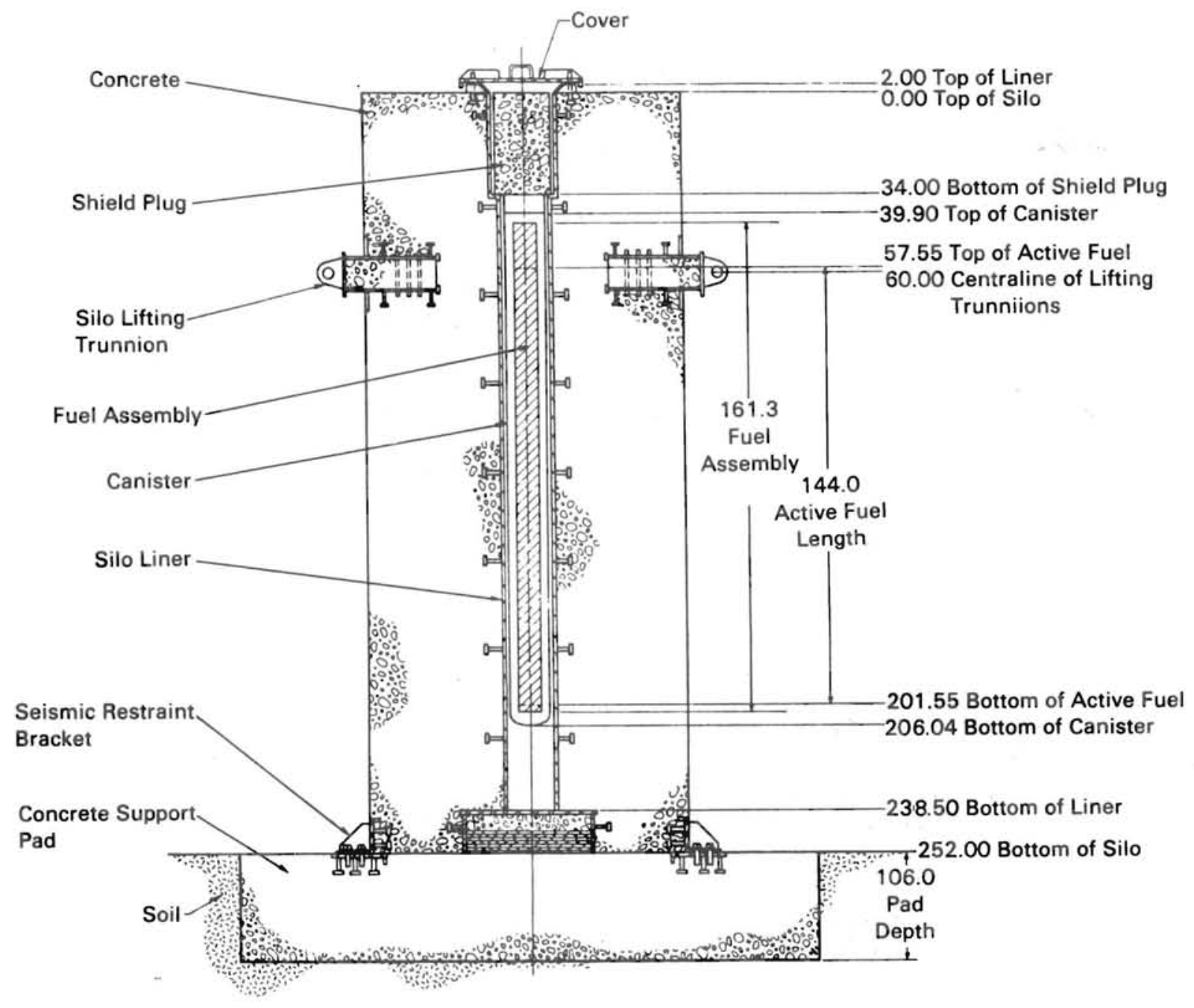

FIGURE 3.11. A Cross-Section of the Concrete Storage Cask Showing Important Measurements (Dimensions in Inches)

liner; 36 additional thermocouples were distributed through the concrete. Two concrete silos were constructed, but only the No. 2 (south) silo was used for demonstration testing.

The encapsulated fuel assembly B02 was placed in silo No. 2 during December 1978 and remained there until late 1982. During this period, temperatures measured by all thermocouples were monitored and the data were reported by Unterzuber et a1. (1982). These temperatures followed seasonal variations in ambient temperature and decay heat. At a decay heat level of $1 \mathrm{~kW}$, the peak 
canister temperature was $141^{\circ} \mathrm{F}\left(61^{\circ} \mathrm{C}\right)$. Using the relations developed in the FAITM tests, the peak fuel temperature was $334^{\circ} \mathrm{F}\left(168^{\circ} \mathrm{C}\right)$, which was well below the storage temperature limit of $716^{\circ} \mathrm{F}\left(380^{\circ} \mathrm{C}\right)$.

\subsubsection{Fuel Assembly Internal Temperature Measurement Testing}

The primary objective of the FAITM tests was to provide spent fuel assembly internal temperature data to verify that spent fuel assemblies with a decay heat level of about $1.0 \mathrm{~kW}$ could be stored in drywells and concrete silos without exceeding design temperature limits. Other objectives included: 1) evaluate the use of the test assembly as a calorimeter; 2) obtain data to define axial and radial temperature distributions in the fuel cladding; 3 ) investigate the thermal effects of using helium, air, or vacuum as the storage atmosphere; and 4) provide data for uniform canister temperatures ranging from 350 to $600^{\circ} \mathrm{F}$.

The FAITM test stand, illustrated in Figure 3.12, consisted of a liner made from 18-in. OD steel pipe with a wall thickness of $0.375 \mathrm{in}$. and a length of $200 \mathrm{in}$. The liner was encircled with band heaters at 6-in. intervals along the length and insulated by a 1-in. air gap between the liner and an enclosing 0.025-in. stainless steel sheath. Additional blanket insulation was provided at the bottom $105 \mathrm{in}$. of the test assembly. The purpose of the heaters was to impose various axial temperature distributions on the liner. The whole assembly was supported by a steel framework and instrumented with a total of 71 thermocouples. Fifty-five thermocouples were attached to the liner, six to the insulating sheath, five to the test stand frame, three to the outside of the insulation blanket, and two to the top plug. The canister used for the FAITM tests was virtually identical to that used in other tests, but it utilized a top closure that included thermocouple wells that fitted into the control rod guide tubes and center instrumentation tubes. A total of 110 thermocouples were provided, seven in each of 15 thermowells, two on the closure lid, and three on the cover plate.

Testing in FAITM proceeded in several phases. First, tests performed to examine and calibrate the facility used an electrically-heated simulated fuel assembly. Next, fuel assembly B43 was inserted in the test assembly and tests were run: 1) using no band heater power, 2) applying band power to simulate 


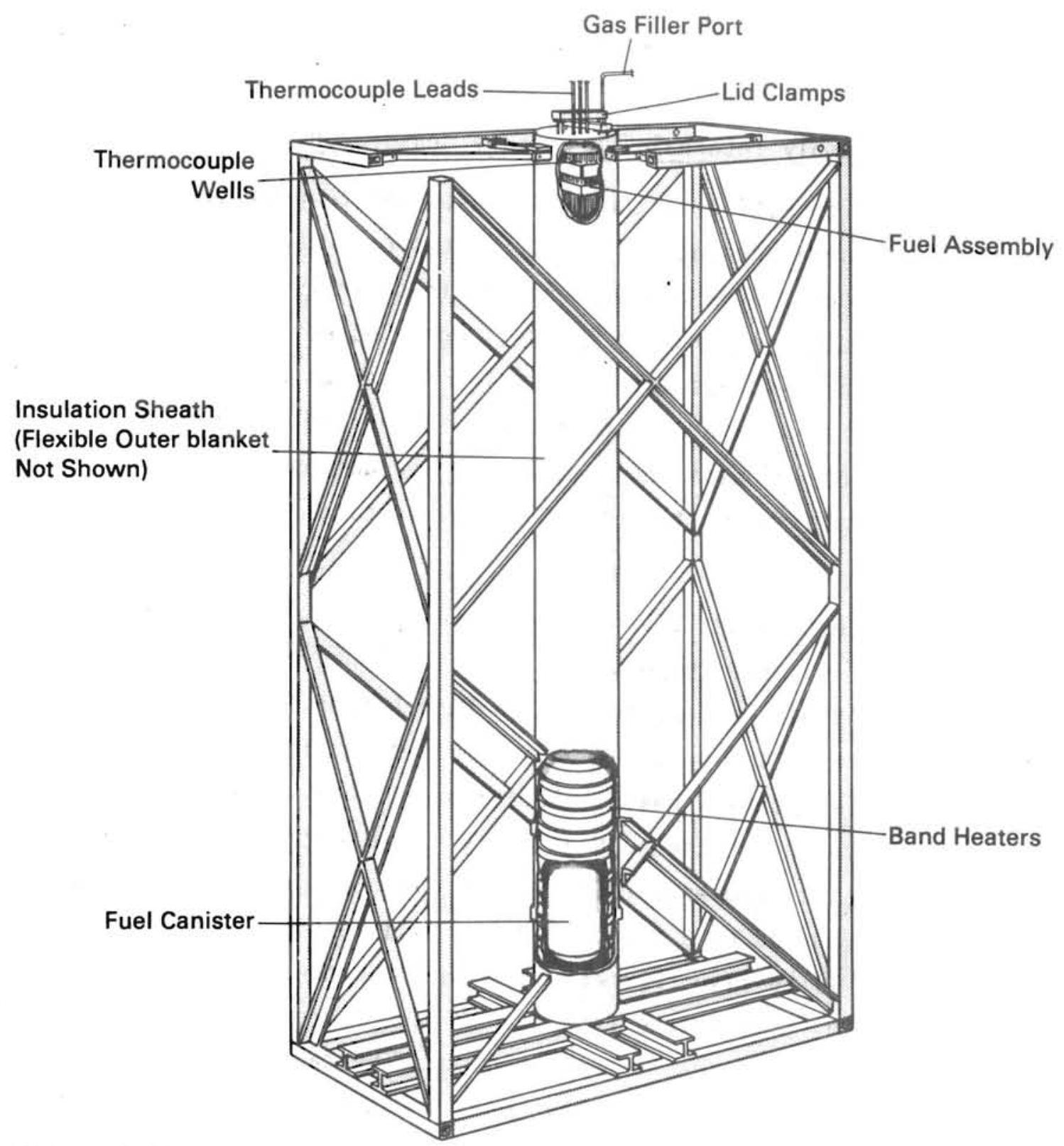

FIGURE 3.12. The General Arrangement of the Apparatus Used for the Fuel Assembly Internal Temperature Measurement (FAITM) Tests and the Fuel Temperature Tests (FTT) 
the drywell test canister temperature profile, 3) imposing the concrete silo canister temperature profiles, and 4) imposing uniform canister profiles between 260 and $500^{\circ} \mathrm{F}\left(127\right.$ and $\left.260^{\circ} \mathrm{C}\right)$. The maximum cladding temperature for assembly $\mathrm{B} 43$ during the calibration tests was $575^{\circ} \mathrm{F}\left(302^{\circ} \mathrm{C}\right)$ in helium. In the next phase, assembly D15 was used and the same general types of experiments were performed. Additional tests were performed to 1) investigate the influence of different canister atmospheres (air, vacuum, and helium) on fuel temperatures, 2) determine the canister profiles from SFT-C, and 3) extend the range of uniform temperatures to $600^{\circ} \mathrm{F}\left(315^{\circ} \mathrm{C}\right)$. The corresponding maximum cladding temperature for $\mathrm{D} 15$ was $680^{\circ} \mathrm{F}\left(360^{\circ} \mathrm{C}\right)$ in helium. Finally, assembly B02 was installed and further fuel temperature tests (FTT) in air were performed to investigate the integrity of the fuel during air storage at temperatures greater than $480^{\circ} \mathrm{F}\left(248^{\circ} \mathrm{C}\right)$. Before $\mathrm{B} 02$ was inserted, two rods were removed and placed into storage to serve as a reference of the initial condition of the fuel. The integrity of the fuel was monitored by analyzing the gas in the canister monthly for the presence of fission gases. The presence of krypton-85 would indicate one or more cladding failures. The duration of the FFT with assembly $\mathrm{BO} 2$ was approximately 24 months.

The data and results of the tests on fuel assemblies B43 and D15 were reported in part by Unterzuber et al. (1982). These results indicated that the FAITM facility did not function well as a calorimeter. Maximum temperatures were recorded under vacuum conditions, and the lowest temperatures were measured in a helium atmosphere. The peak recorded temperature of the fuel assembly was $680^{\circ} \mathrm{F}\left(360^{\circ} \mathrm{C}\right)$, which corresponds to a canister temperature of $595^{\circ} \mathrm{F}\left(313^{\circ} \mathrm{C}\right)$. A set of empirical equations was obtained from the data to express the peak fuel temperature as a function of canister temperature and the decay heat rate. These equations are summarized in the Appendix C. Separate equations were obtained for each fuel assembly and each backfill gas.

The long-term tests of B02 in air were reported by Johnson et al. (1986). The results indicated that breaching of one or more rods occurred after approximately 2 months at an initial temperature of $527^{\circ} \mathrm{F}\left(275^{\circ} \mathrm{C}\right)$, decreasing to simulate decreasing decay heat. Although there were several 
possible explanations for the breach, analysis suggested that it occurred in a rod weakened by a cladding or end cap defect.

\subsubsection{Air-Cooled Vault Tests}

The objective of the Air-Cooled Vault Tests were to provide temperature and flow data under normal operating and simulated accident conditions to verify that spent fuel with decay heat levels of $2.0 \mathrm{~kW}$ could be stored in the EMAD lag storage pit without violating the fuel cladding temperature limit. Accident conditions of particular interest included both partial and complete loss of forced air cooling. All of the 13 fuel assemblies involved in these tests were being stored in the lag pit prior to and following the SFT-C tests.

The lag storage pit is illustrated in Figures 3.13, 3.14, and 3.15. The pit consisted of three individual concrete-lined vaults, each capable of holding eight individual canisters. Decay heat was dissipated through an air duct

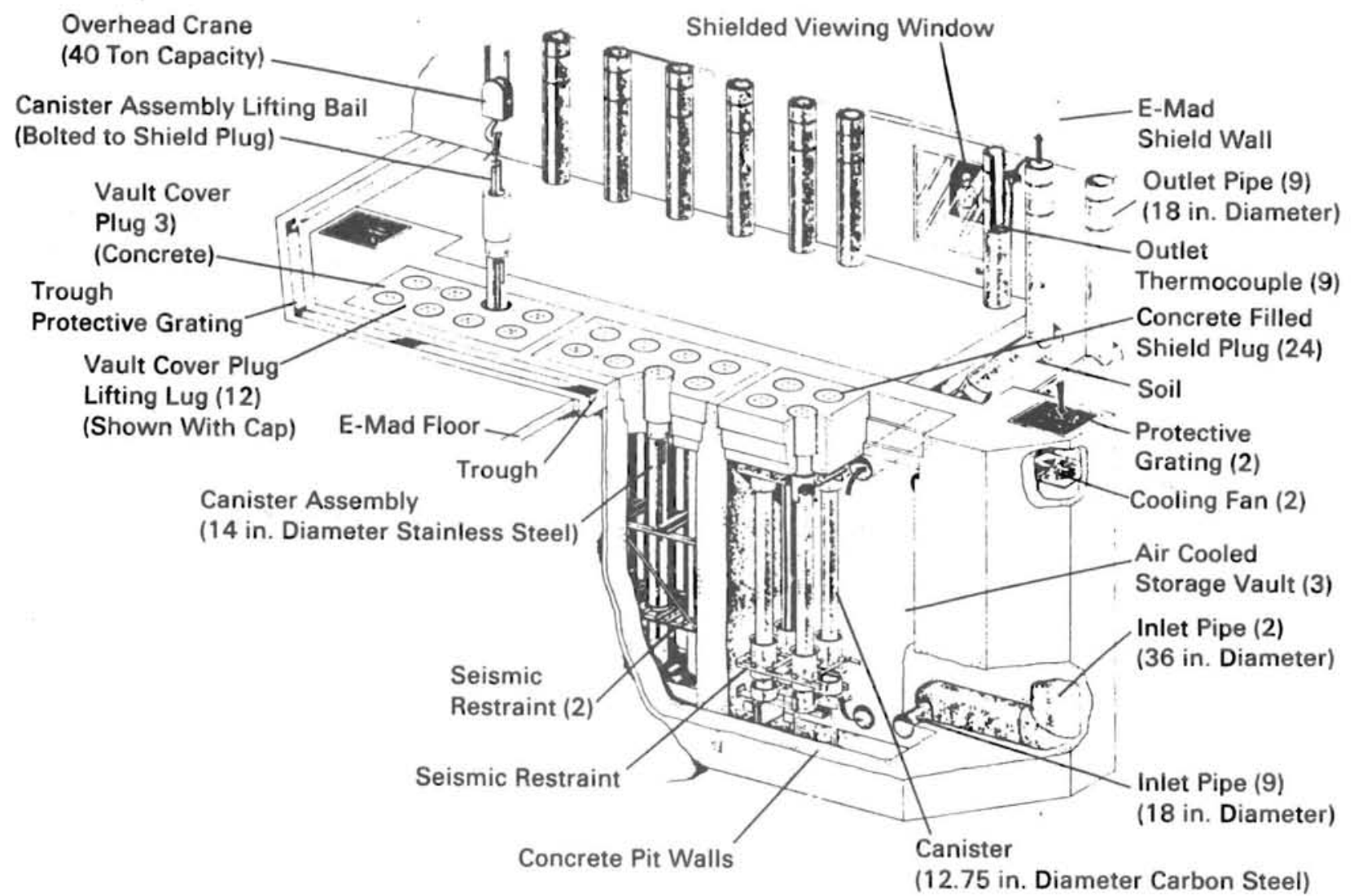

FIGURE 3.13. Arrangement of the EMAD Lag Storage Pit Used in the Air-Cooled Vault Tests 


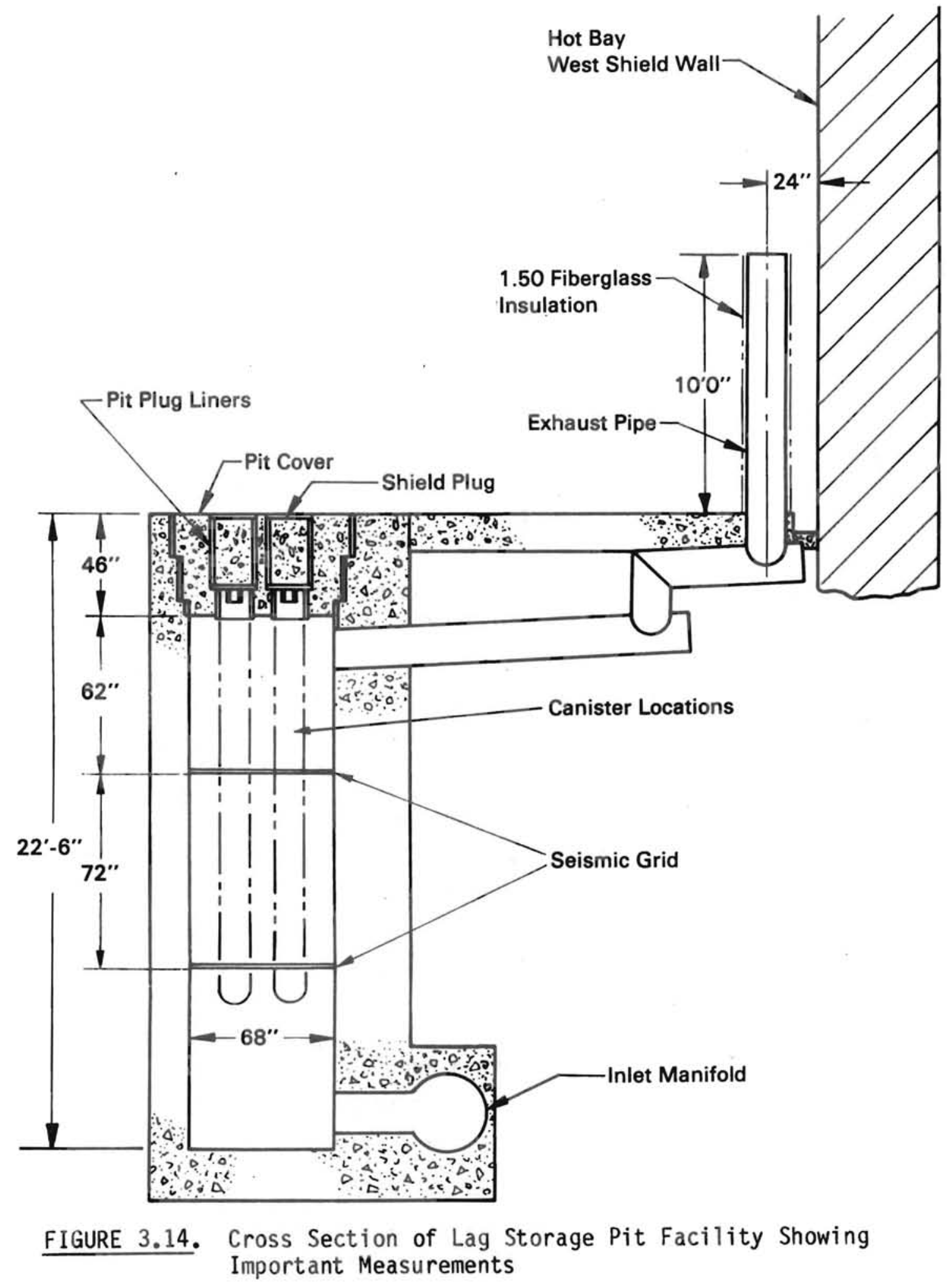




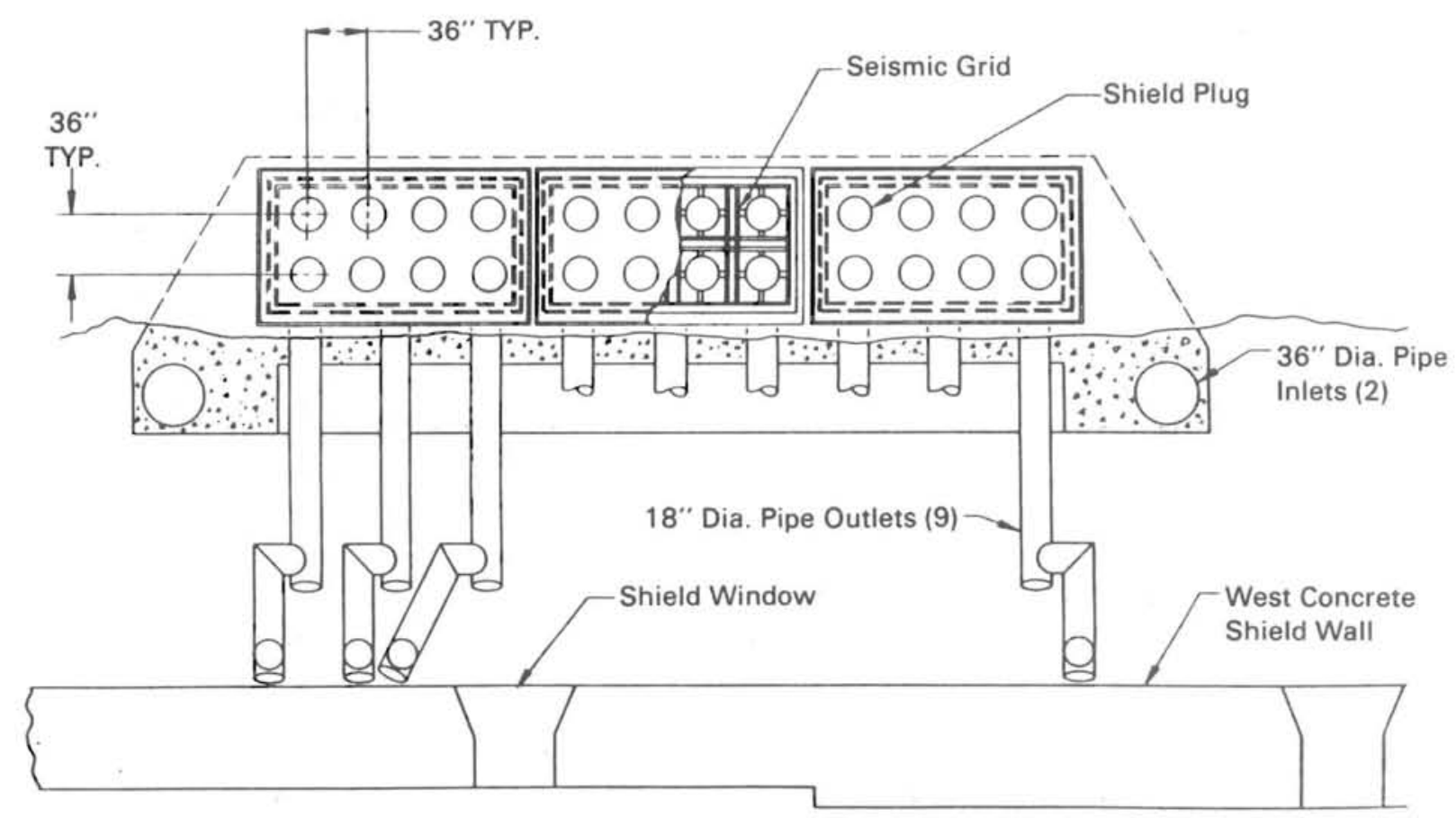

FIGURE 3.15. Plan View of Lag Storage Pit Facility Showing the Relationship Between Individual Storage Locations

array connected to the pit. Each vault was $11 \mathrm{ft} 8 \mathrm{in}$. 1ong, $5 \mathrm{ft} 8 \mathrm{in}$. wide and $22 \mathrm{ft} 6 \mathrm{in}$. deep. Each vault had a stepped concrete cover $13 \mathrm{ft}$ by $7 \mathrm{ft}$ and $46 \mathrm{in}$. thick. The vault cover plugs had holes to accept the canisters with shield plugs attached. The spacing of the holes, and therefore, the fuel assemblies spacing, was $36 \mathrm{in}$., which precluded criticality if the pit was flooded with water. Two 42-in.-diameter fans with electric motors capable of $17,720 \mathrm{ft}^{3} / \mathrm{min}$ supplied the cooling air. The outlet pipes were provided with nine thermocouples for the measurement of air temperature. A hand-held velocimeter was used to measure airflow rates from the outlet pipes.

Tests were performed with both 4 and 11 fuel assemblies present. Outlet temperatures, outlet flow rates, and the temperatures of one canister (D22) were measured with both fans operating; only one fan operating; one fan operating with the other blocked; and neither fan operating (natural circulation). The final two assemblies were added, and the temperatures were monitored under normal operating conditions until all assemblies were moved to SFT-C. When the canister containing assembly D06 was returned from SFT-C, instrumented 
monitoring of the system continued. The results of these tests indicated that peak canister temperatures of 149 and $181^{\circ} \mathrm{F}\left(65\right.$ and $83^{\circ} \mathrm{C}$ ) were obtained with a fuel assembly generating about $1.8 \mathrm{~kW}$ for normal forced cooling and the worstcase condition of natural circulation, respectively. This latter temperature occurred only briefly and corresponded to a fuel cladding temperature of $532^{\circ} \mathrm{F}$ $\left(278^{\circ} \mathrm{C}\right)$, which is well below the limit of $716^{\circ} \mathrm{F}\left(380^{\circ} \mathrm{C}\right)$. The data obtained in the tests prior to 1982 were reported by Unterzuber et al. (1982) and Unterzuber (1981).

\subsubsection{Decay Heat Measurements}

During the demonstration testing, tests were performed to define the current value of the decay heat generation in various spent fuel assemblies using a calorimeter installed in the EMAD hot bay facility. The calorimeter, described by Creer and Shupe (1981), used a water boil-off principal and is illustrated in Figures 3.16 and 3.17 ). It consisted of five major subsystems: 1) the calorimeter vessel with supporting structure, 2) the water supply/storage tank and fill pump, 3) the steam condenser, 4) the condensate collection apparatus, and 5) the data acquisition system. The calorimeter vessel consisted of a vertical, 20-in. 0D, 18-ft-long stainless steel pipe closed at the bottom and containing an inner pipe that supported lead rings to absorb gamma energy radiated from the spent fuel placed inside it. The vessel also contained electric heaters to supply heat to mask losses during testing. The water storage tank was located directly below the vessel to provide make-up water and to facilitate complete vessel drainage. The condenser and condensate collection system were used to condense the steam generated in the calorimeter, to collect subcooled condensate over a recorded period of time, and to measure both the volume and weight of condensate collected.

The calorimeter was operated by filling the vessel to a prescribed level before the fuel was inserted and supplying electrical energy to the heaters. When the calorimeter reached equilibrium, the amount of condensate produced was measured over a period of time. With the electrical heat generation rate being held constant, the spent fuel assemblies was inserted and the level adjusted to the prescribed level. Due to the decay heat, an additional amount of condensate was produced; the latent heat associated with this additional condensate 


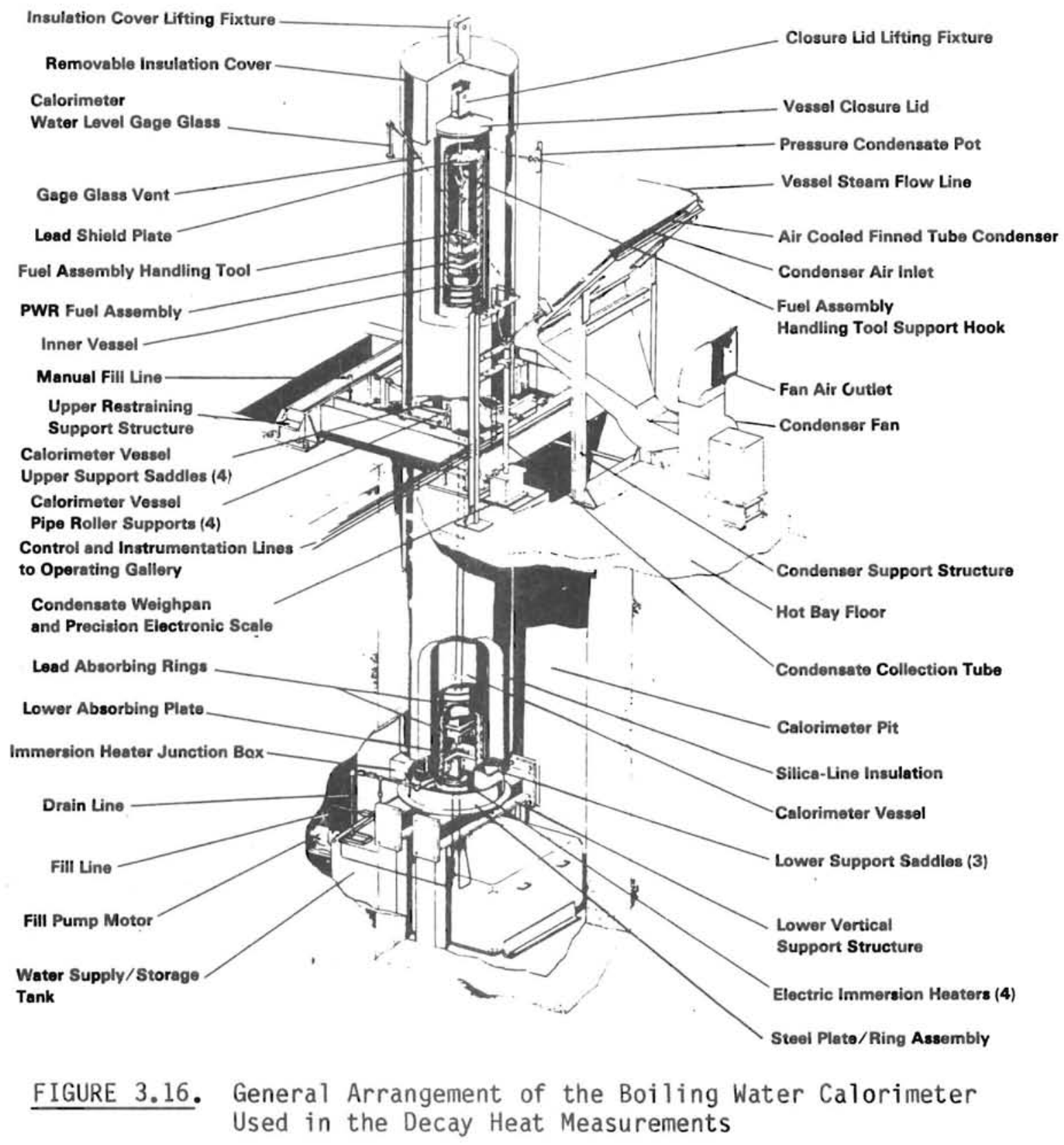




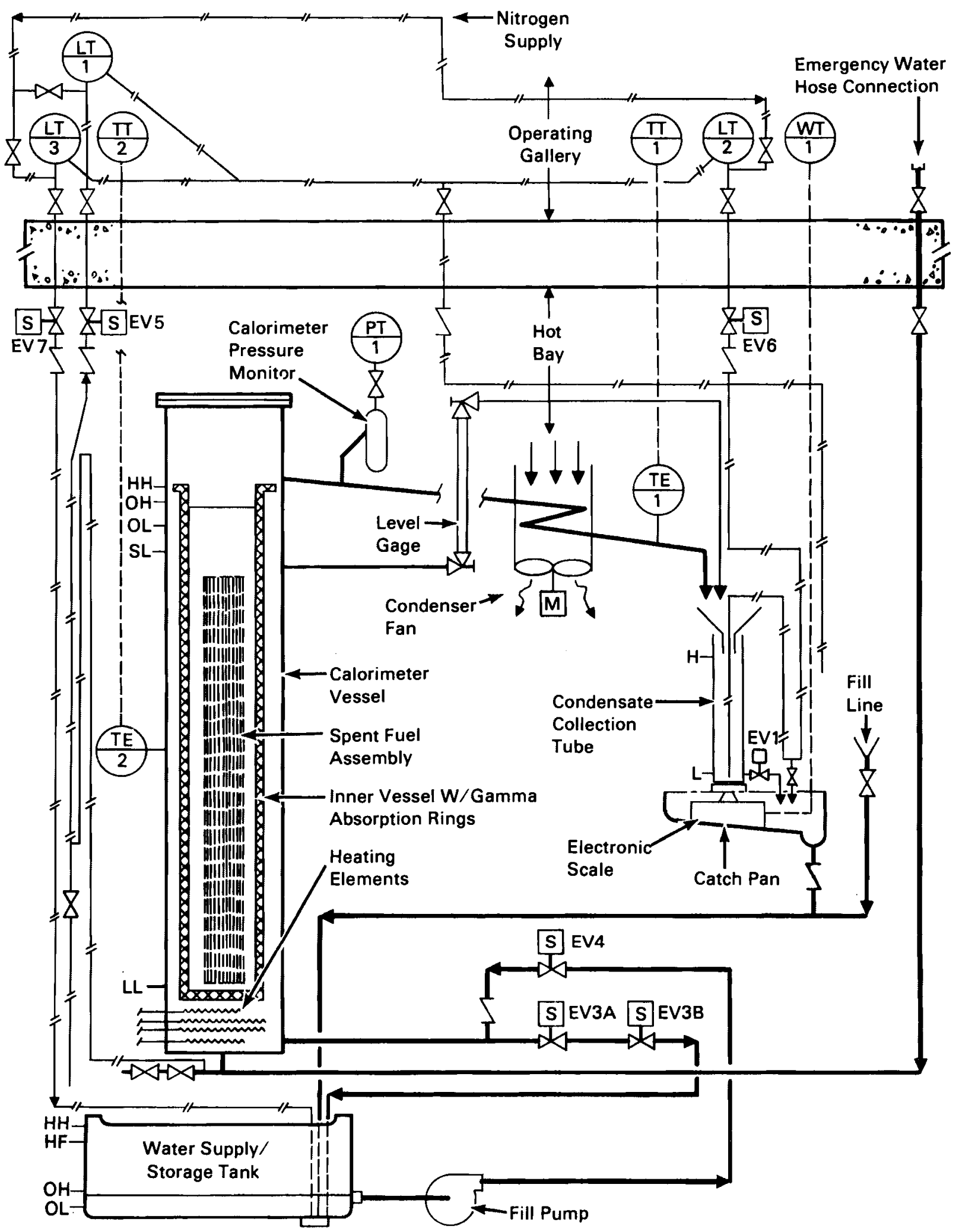

FIGURE 3.17. Calorimeter System Flow and Instrumentation Diagram 
collected over a period of time was equivalent to the heat generated during this period. Analysis showed that if true equilibrium conditions are obtained, this apparatus is capable of $6 \%$ accuracy. The calorimeter tests are described in Creer et al. (1981), Unterzuber et al. (1982), and Patrick et al. (1983). The results of tests performed on the various fuel assemblies are summarized in Appendix B. In general, measured heat generation rates were within $3 \%$ to $5.8 \%$ of values calculated using the ORIGEN2 computer code.

\subsection{SPENT FUEL TEST AT CLIMAX}

The objective of the SFT-C Program was to evaluate the reliable short-term storage of spent reactor fuel assemblies in a typical granitic rock and to demonstrate its safe emplacement and retrieval. Of principal concern were the temperatures in the spent fuel and rock, thermal stresses in the rock, and radiation exposures of workers over the period of storage. The rock temperatures and stresses were used to calibrate and verify computer predictions of rock behavior.

The SFT-C facility and site characterization were described by Patrick et al. (1982) and Brough and Patrick (1982). Figures 3.18 and 3.19 give plan and cross-section drawings of the subsurface spent fuel storage test layout. The spent fuel storage site consists of a storage tunnel, or drift, $15 \mathrm{ft}$ wide and $20 \mathrm{ft}$ high mined in granitic rock $1400 \mathrm{ft}$ below the surface about 59 miles from the EMAD facility in the northeastern part of NTS. In the floor of the storage tunnel, 17 storage wells (shown in Figure 3.20) were provided at 10-ft intervals for the spent fuel. Two 11-ft-wide and 11-ft-high drifts were mined on each side of the storage drift. Electrical heaters were placed in the floor of these drifts to provide a "guard heating" effect and to make the thermal environment of the spent fuel storage locations equivalent to that of an infinite array. The site was extensively instrumented with over 500 thermocouples, thermistors, and resistance temperature devices; rock displacement and stress measurement devices at nearly 200 locations; and an array of continuous air monitors and remote area monitors to assure the health and safety of personnel. Surface facilities included an office and data acquisition support structure, a headframe, a hoist control room, and uninterruptible power supply. 


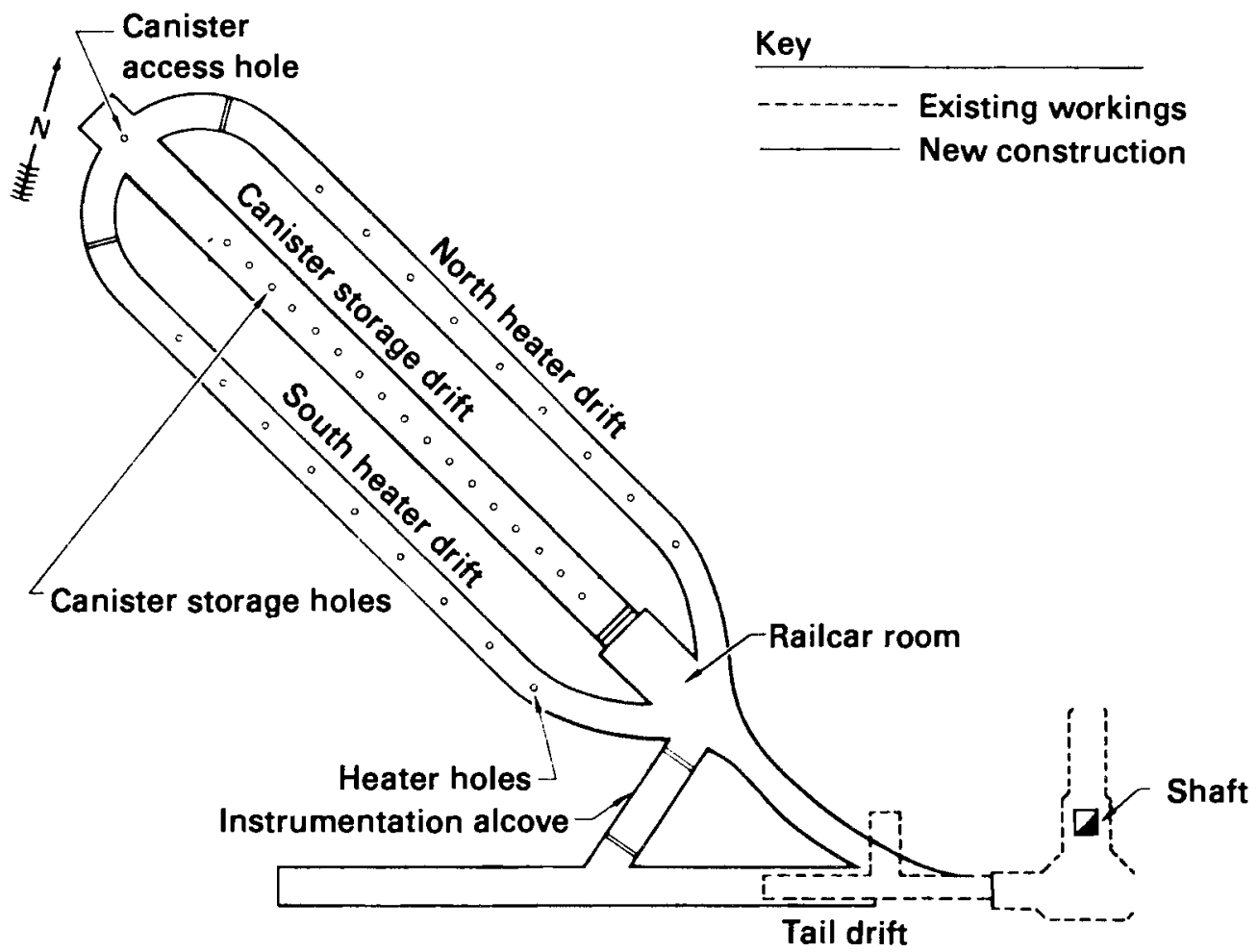

FIGURE 3.18. The Arrangement of the Climax Underground Facilities at the $1400 \mathrm{ft}$ Level

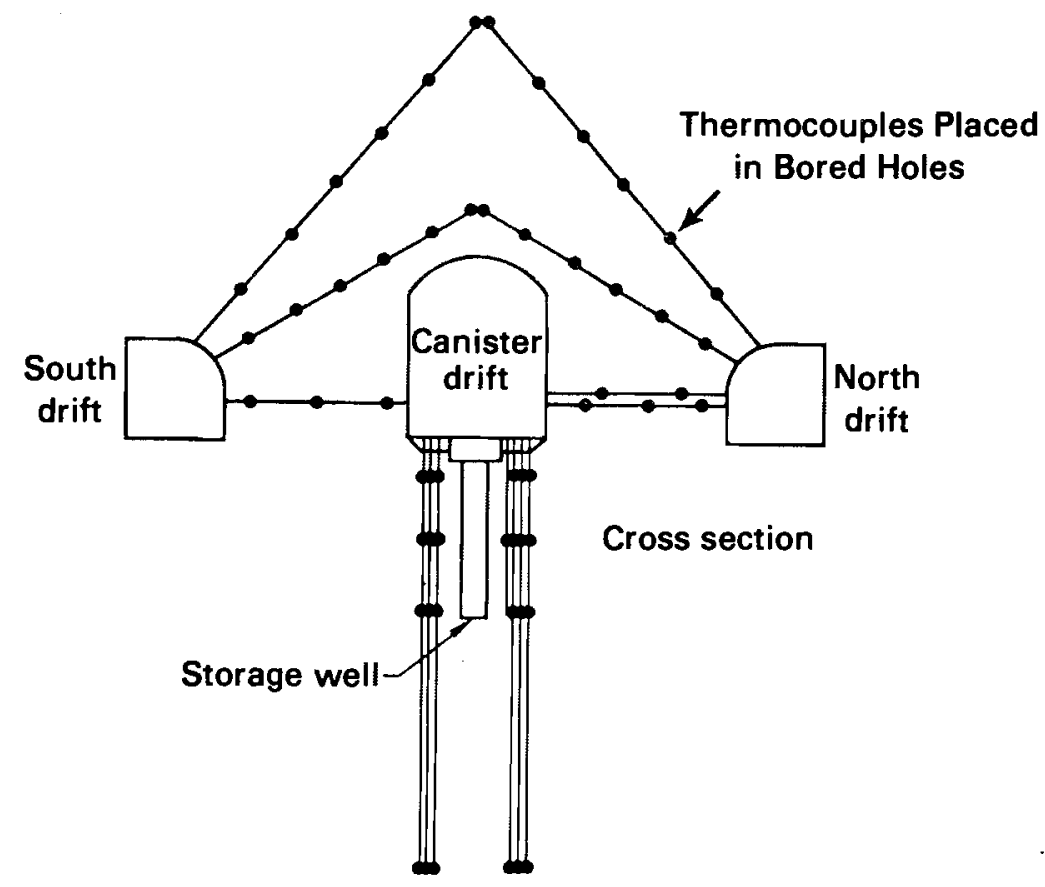

FIGURE 3.19. Climax Canister and Heater Drifts Showing Typical Instrumentation Placement 


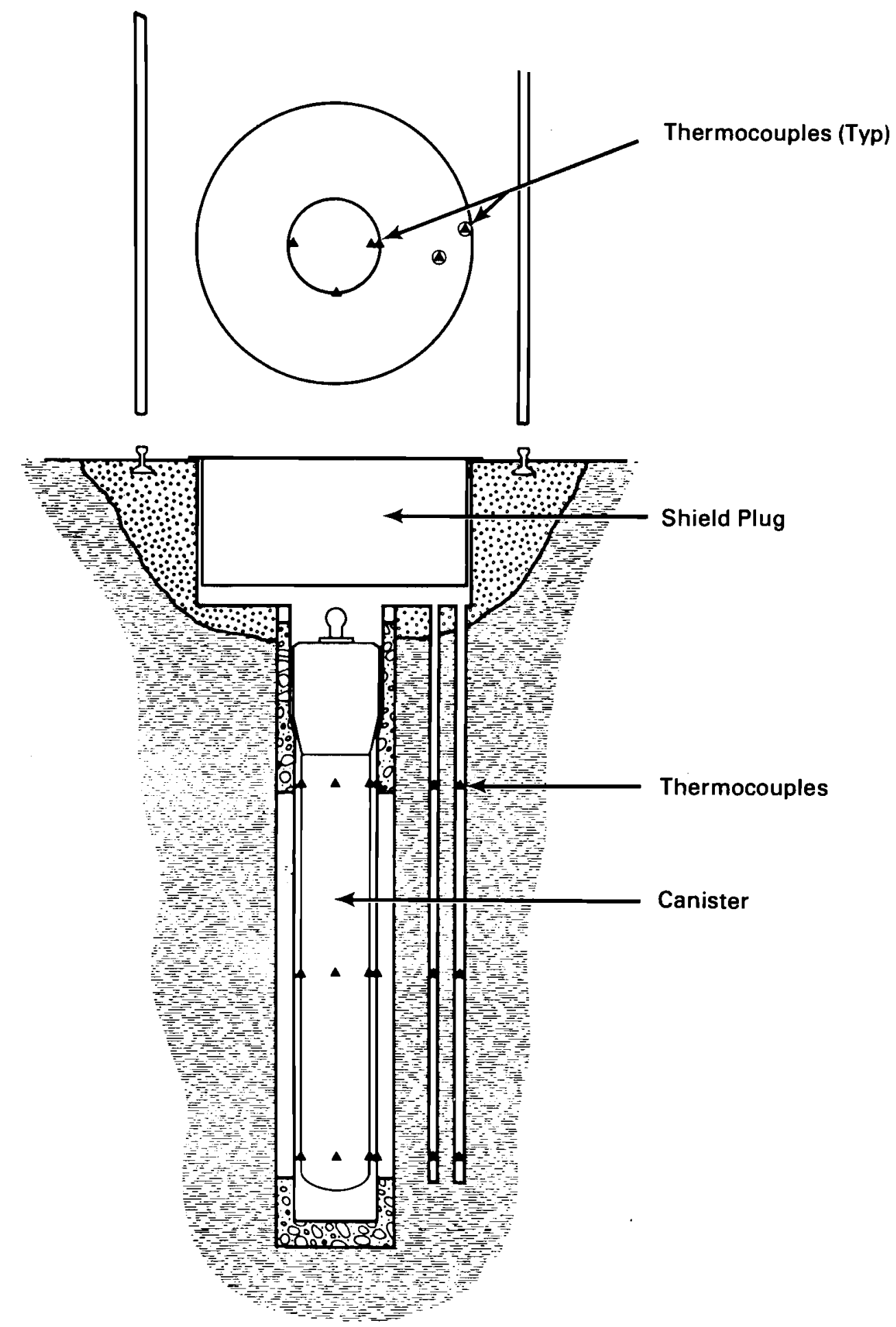

FIGURE 3.20. A Cross-Section of a Typical Climax Fuel Storage Well Showing Near-Field Thermocouples 
The spent fuel assemblies for the SFT-C tests were first encapsulated at the EMAD facility as described in Section 3.2.1 and then transported to the SFT-C site with a semi-trailer with a mounted 40-tonne shielding cask. This cask was specially designed to carry the encapsulated fuel assemblies because they were too large in diameter for a licensed tractor-trailer transporter. Upon arrival at SFT-C, the fuel was lowered through a bored access hole to the storage test level by means of a hoist attached to the headframe. The spent fuel was received on the test level by a rail-mounted transfer vehicle; another 40-tonne shielding cask was mounted on it. The vehicle moved the fuel assembly between the access shaft and the canister emplacement holes; a jib crane was used to remove the shielding plug and lower the fuel assembly canister into the hole.

In April and May 1980, 11 spent fuel assemblies were emplaced in the SFT-C storage locations; the remaining storage holes were equipped with electric heaters to simulate the presence of fuel. The fuel assemblies originally emplaced included D01, D04, D06, D09, D16, D18, D34, D35, D40, D46, and D47. Assemblies D15 and D22 later were added and D09, D06, and D04 were returned to EMAD during planned rearrangement of the spent fuel in SFT-C storage wells. In March and April of 1983, the spent fuel was retrieved from SFT-C and returned to EMAD; all electrical heaters were deenergized, and the site was allowed to cool for post-test characterization.

The preliminary results of the test program were summarized by Patrick et al. (1984). These results indicated that the peak measured temperature of the fuel canister (location CEHO9) occurred within the first 2 months after emplacement and was approximately $293^{\circ} \mathrm{F}\left(145^{\circ} \mathrm{C}\right)$.

\subsubsection{Post-Test Evaluation of Fuel at EMAD}

Once the spent fuel was returned from SFT-C, tests to determine its integrity were performed at EMAD. These tests included the evaluations described in Section 5 and decay heat measurements described in Section 3.1. 


\subsection{RELATED ROD AND ROD SEGMENT TESTING}

Fuel assembly $B 17$ was partially disassembled at $B C L$, and selected rods were used in both single-rod tests at $B C L$ and rod-segment tests at ANL and $\mathrm{BCL}$. Because of the relationship of these tests to the demonstration testing at NTS, a brief description is provided here.

\subsubsection{Tests of Single Rods Under Dry Storage Conditions}

Accelerated high-temperature aging tests of 13 fuel rods from assembly B17 and one from D04 were performed at BCL (Einziger et al. 1982). The objectives of these tests were to determine the dominant mode of cladding breach and the degree of cladding degradation during dry storage. Before testing, the conditions of the rods were characterized by means of nondestructive examinations and destructive examinations of companion rods. Nondestructive examinations included: 1) visual examinations of crud accumulation and gross defects, 2) measurements of length and diameter, and 3) gamma scans to determine both cesium-137 and total fission product distributions. The destructive examinations included measurements of internal pressure, fission gas content, surface oxidation, hydride structure, and cladding corrosion. Following the characterizations, the rods were placed in individual capsules and pressurized with helium or air to $0.14 \mathrm{MPa}$. One group of encapsulated rods with both helium and air atmospheres were held at $950^{\circ} \mathrm{F}\left(510^{\circ} \mathrm{C}\right)$ for $7680 \mathrm{~h}$. Another group was subjected to $900^{\circ} \mathrm{F}\left(482^{\circ} \mathrm{C}\right)$ for $4656 \mathrm{~h}$ and $1060^{\circ} \mathrm{F}\left(571^{\circ} \mathrm{C}\right)$ for $2480 \mathrm{~h}$ with interim examinations. No cladding breaches occurred even though the test duration was many orders of magnitude longer than the lifetime of the rods as predicted by Blackburn's analysis (Blackburn et a1. 1978). The extended lifetime was due to significant creep strain of the Zircaloy cladding, which was observed to decrease the internal rod pressure. The cladding creep was also found to contribute to radial cracks through the external oxide and fuel-cladding interaction layers. These cracks propagated into and arrested in an oxygen stabilized alpha-Zircaloy layer. No signs were observed of either additional cladding hydriding, stress corrosion cracking or fuel pellet degradation. It was concluded that if the irradiated Zircaloy cladding is annealed during processing, storage, or disposal, $752^{\circ} \mathrm{F}\left(400^{\circ} \mathrm{C}\right)$ is a conservative upper limit for 1000-year cladding integrity based on a stress-rupture mechanism. Such 
annealing of irradiation hardening occurs rapidly at temperatures near or above $752^{\circ} \mathrm{F}\left(400^{\circ} \mathrm{C}\right)$. At lower storage temperatures, the possibility of significantly shorter lifetimes may occur, but these lifetimes were not quantified because of uncertainty in the stress-rupture properties of irradiated Zircaloy. However, modeling of Zircaloy-clad fuel provides a basis to predict Zircaloy cladding behavior under dry storage conditions (Chin, Khan, and Tarn 1986).

\subsubsection{0xidation Testing of Rod Segments}

Experiments were performed at ANL (Einziger and Strain 1986) under sponsorship of the Electric Power Research Institute (EPRI) and the Tennessee Valley Authority (TVA) to investigate the effects of temperature and environment on the oxidation of $\mathrm{UO}_{2}$ and to determine whether the size of cladding defects affects the oxidation of a breached rod. These tests were performed using 8-in.-long segments of rods F6 and Jl0 from fuel assembly B17; another segment from a BWR spent fuel rod was also tested.

The rods were cut into segments in air and approximately $3 / 4 \mathrm{in}$. of fuel was removed from each end of the segments. The ends were fitted with closefitting end plugs and sealed pressure-tight with mechanical closures. Only minimal characterization of the test sample was conducted, because the characterization of adjacent rods in B17 had shown consistent properties. Defects were produced in these rod segments by one of two methods: 1) a $0.760-m m-d i a$ hole was bored in the cladding using a carbide drill; or 2) a cladding crack was induced by introducing iodine in the segment before sealing (free iodine enhances propensity for stress corrosion cracking) and then subjecting it to $617^{\circ} \mathrm{F}$ with an internal pressure of $2175 \mathrm{psi}$. The defects induced by this procedure were in the form of axial cracks with an "effective circular diameter" of between 0.008 and $0.040 \mathrm{~mm}$. Experiments were performed at temperatures ranging between $482^{\circ} \mathrm{F}\left(250^{\circ} \mathrm{C}\right)$ and $680^{\circ} \mathrm{F}\left(360^{\circ} \mathrm{C}\right)$ in a flowing air atmosphere.

A typical experiment consisted of placing in a furnace at least one rod segment with a drilled defect, at least one rod segment with an induced defect, and one or more nickel-chromium crucibles containing fuel fragments. The furnace was slowly warmed to the test temperature and maintained for periods of 
time ranging from $12 \mathrm{~h}$ at $680^{\circ} \mathrm{F}\left(360^{\circ} \mathrm{C}\right)$ to $10,000 \mathrm{~h}$ at $482^{\circ} \mathrm{F}\left(250^{\circ} \mathrm{C}\right)$. Periodically, the test was stopped for visual inspection and measurement of the rods and for weighing of the fuel fragments.

In all cases, the bare fuel fragments started oxidizing sooner than the fuel in the defected rod segments. Both the size and the shape of the defects affected the time for the cladding to split. At temperatures greater than $482^{\circ} \mathrm{F}\left(250^{\circ} \mathrm{C}\right)$, the time required for splitting was shorter for the larger drilled holes, apparently because the small defects limited the oxygen supply. At the lower temperatures, where reactions are slower, small cracks split open before the drilled holes, apparently because of the stress states at the tips of the cracks. Although the test data were insufficient to establish an absolute safe air storage temperature, the authors suggested that at approximately $446^{\circ} \mathrm{F}\left(230^{\circ} \mathrm{C}\right)$ the rate and manner of fuel oxidation in air are such that gross cladding failure would be unlikely in 100 years of air storage. 


\subsection{FUEL THERMAL HISTORY}

The temperature histories of the 17 fuel assemblies while at the NTS are summarized in Figure 4.1 to 4.17 and are based on monthly temperature monitoring data. They do not reflect short-term temperature deviations such as may occur during transport, processing, and malfunctions (such as power outages) during testing. These temperature deviations were, in general, lower than the maximum dry storage temperatures encountered immediately before or after the deviation. An example of such deviations can be seen in the data from the FTT which was recorded at more frequent intervals and is shown in Figure 4.18 (Johnson et al. 1985). More detailed temperature histories have been reported by Unterzuber (1981).

Temperatures were not monitored on all of the spent fuel assemblies during this history; however, missing temperature data were inferred from measurements made from other monitored fuel assemblies located in adjacent or later in the same storage location. In most cases, fuel cladding temperatures were not measured directly; only canister temperatures were measured. Using the results of the FAITM tests, equations were developed to infer maximum cladding temperatures from the canister temperatures. These equations are described in Appendix $C$. The sources of the temperatures plotted in the thermal histories are included in the following symbols for Figures 4.1 through 4.17 .

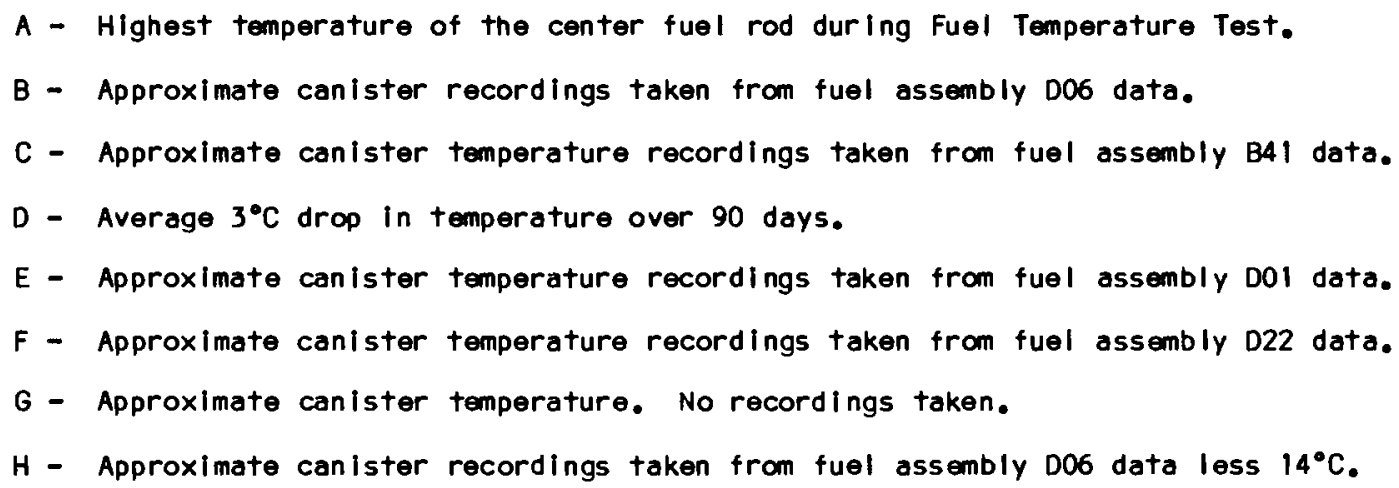




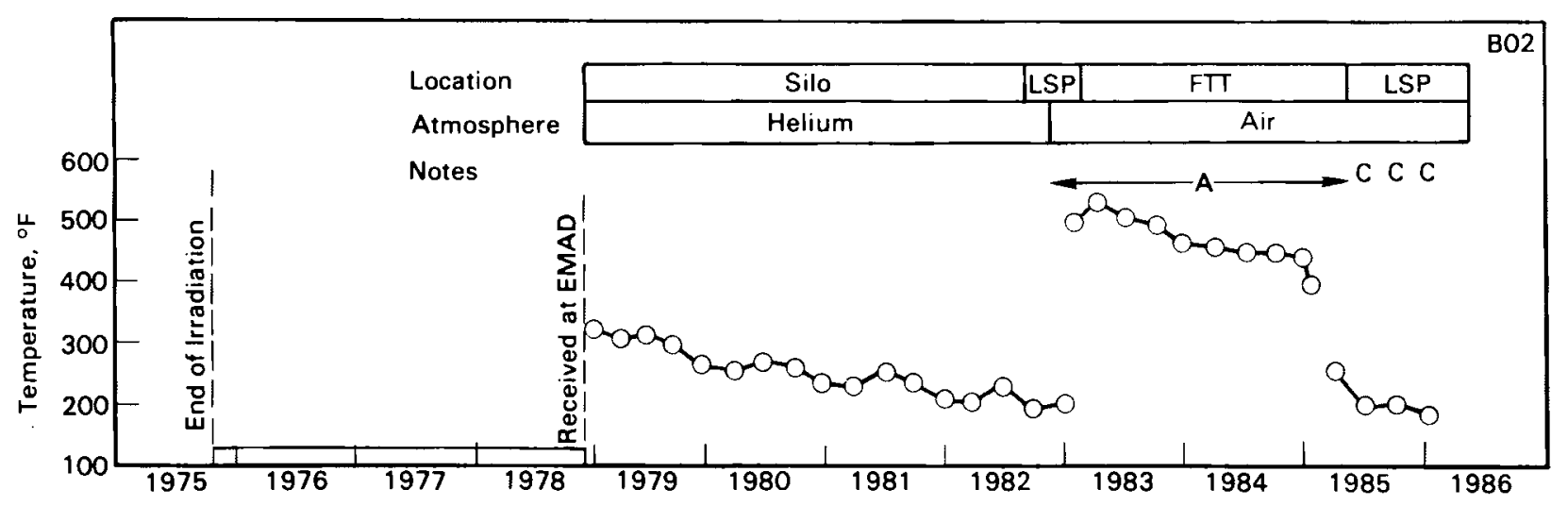

FIGURE 4.1. Thermal History of Fuel Assembly B02

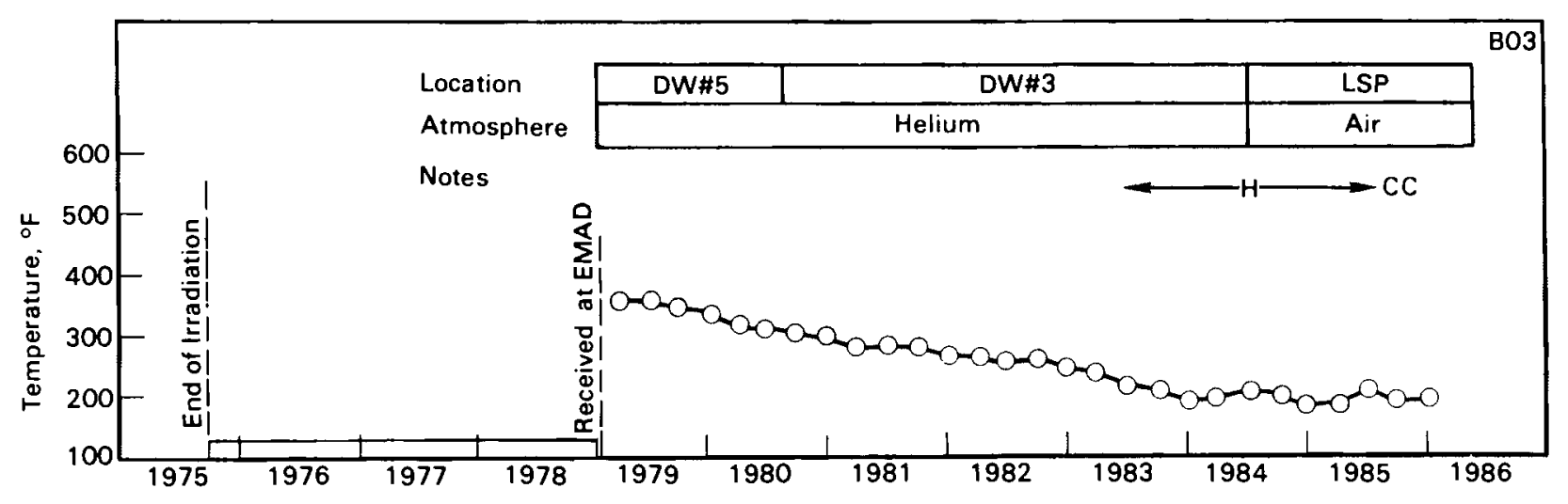

FIGURE 4.2. Thermal History of Fuel Assembly B03

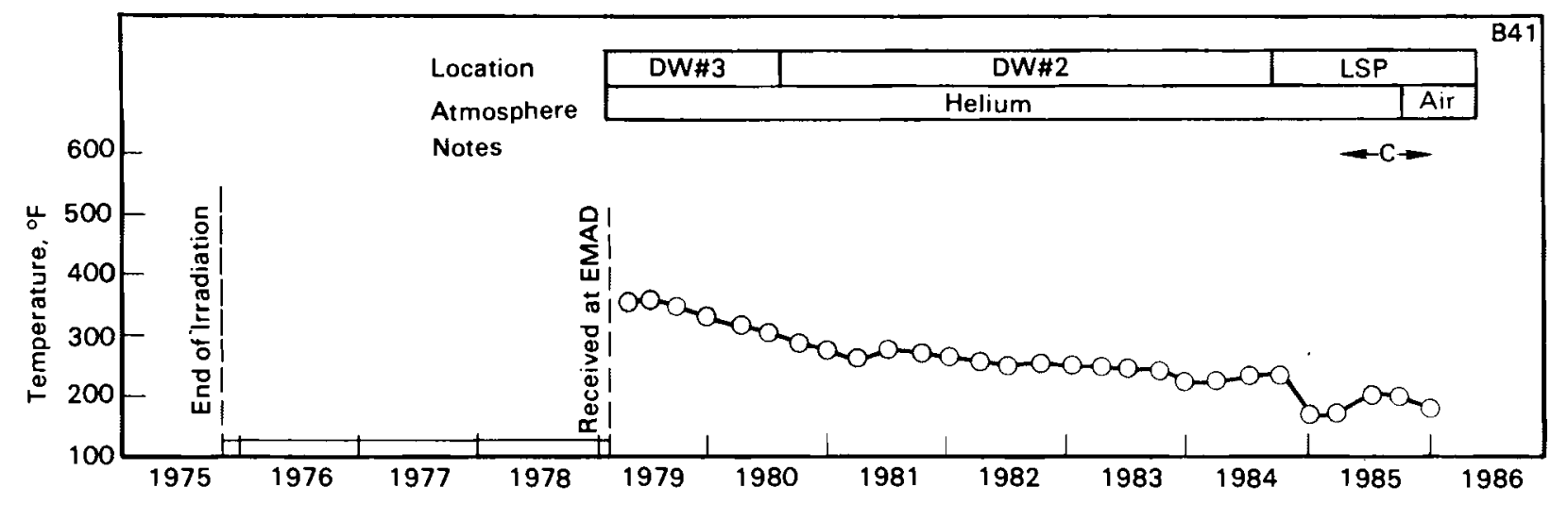

FIGURE 4.3. Thermal History of Fuel Assembly B41 


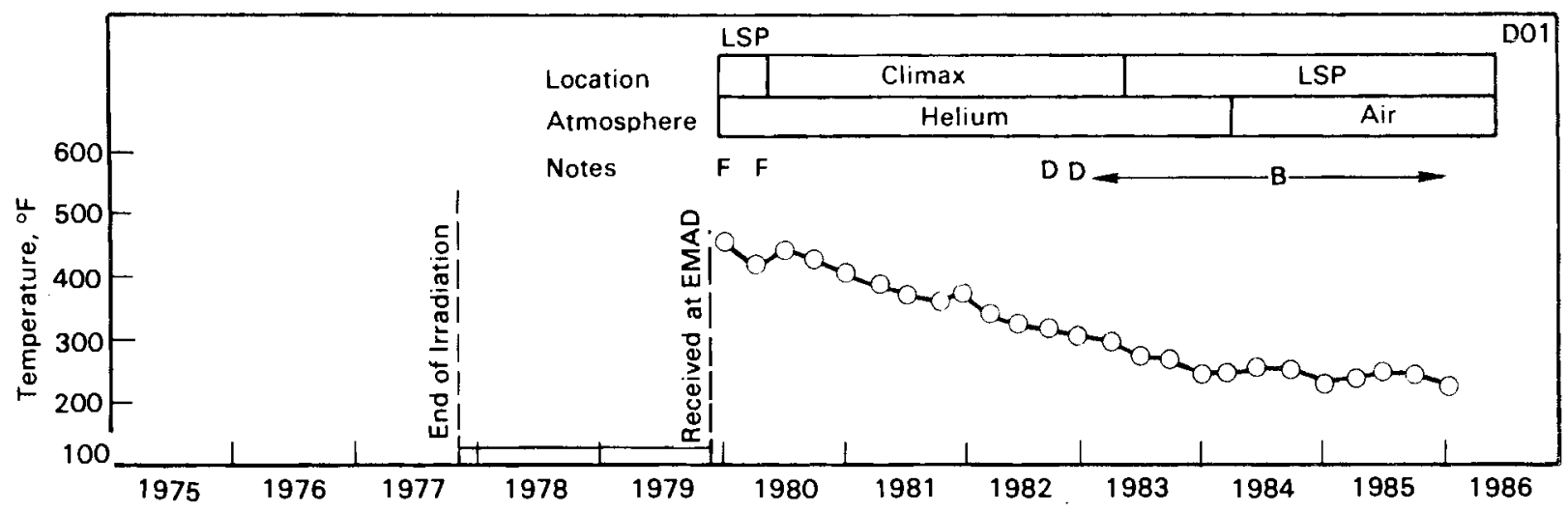

FIGURE 4.4. Thermal History of Fuel Assembly B43 ( $V=$ Vacuum). Not shown are maximum cladding temperatures up to $575^{\circ} \mathrm{F}\left(302^{\circ} \mathrm{C}\right)$ during brief calibration tests.
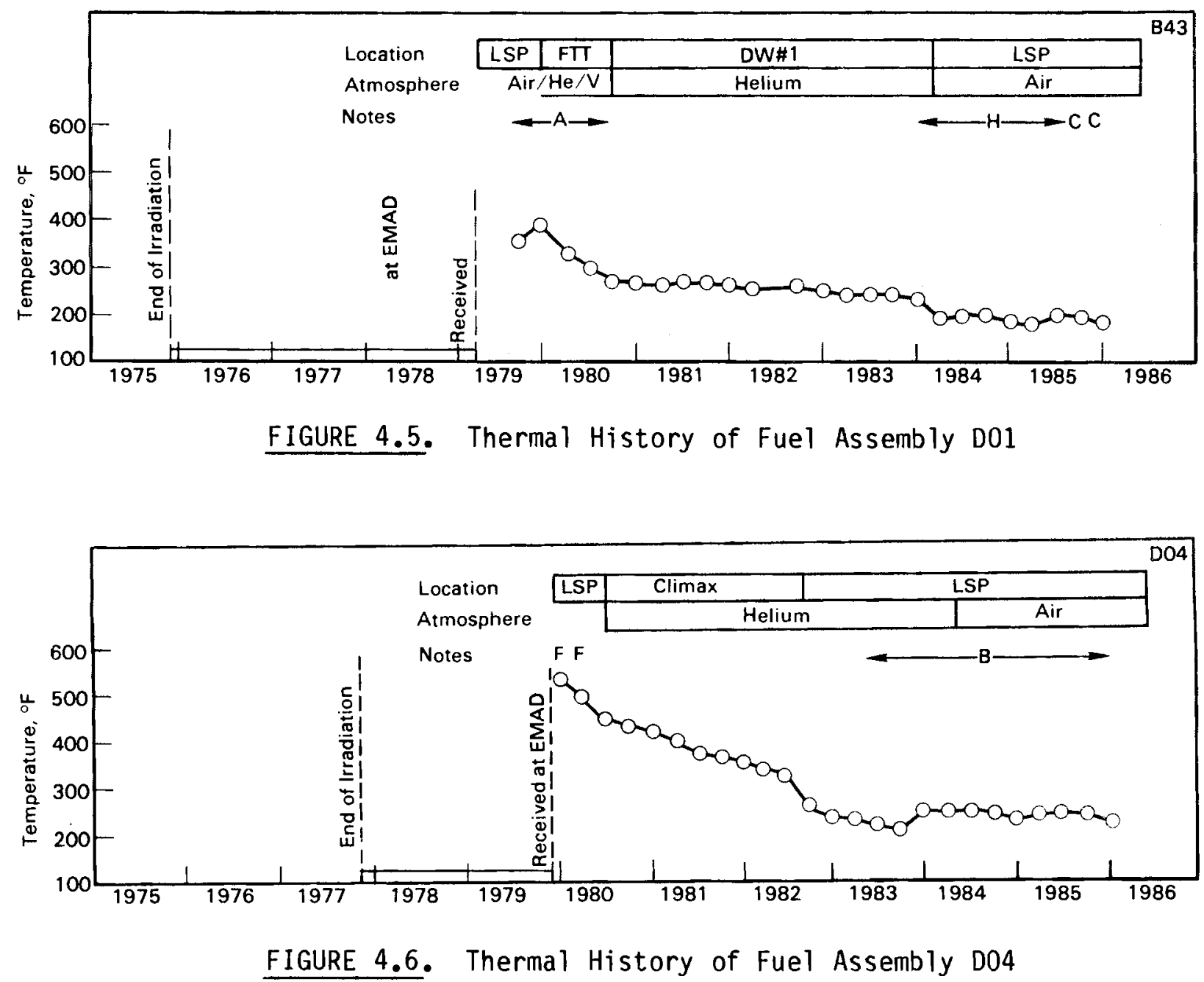


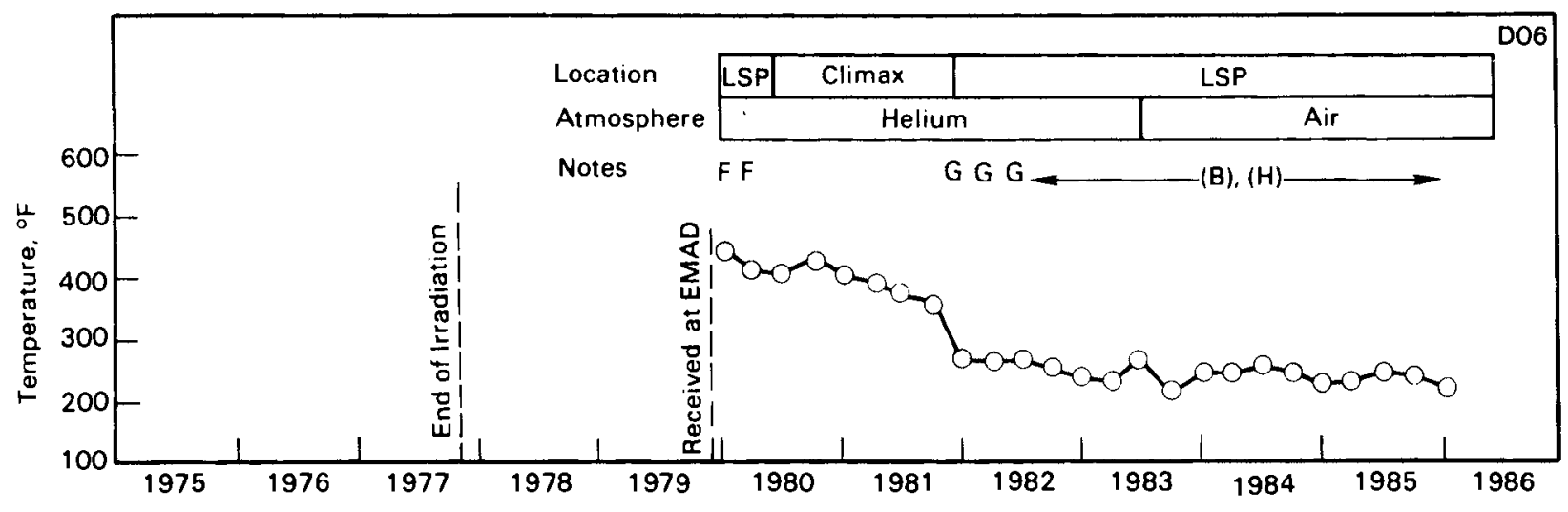

FIGURE 4.7. Thermal History of Fuel Assembly D06
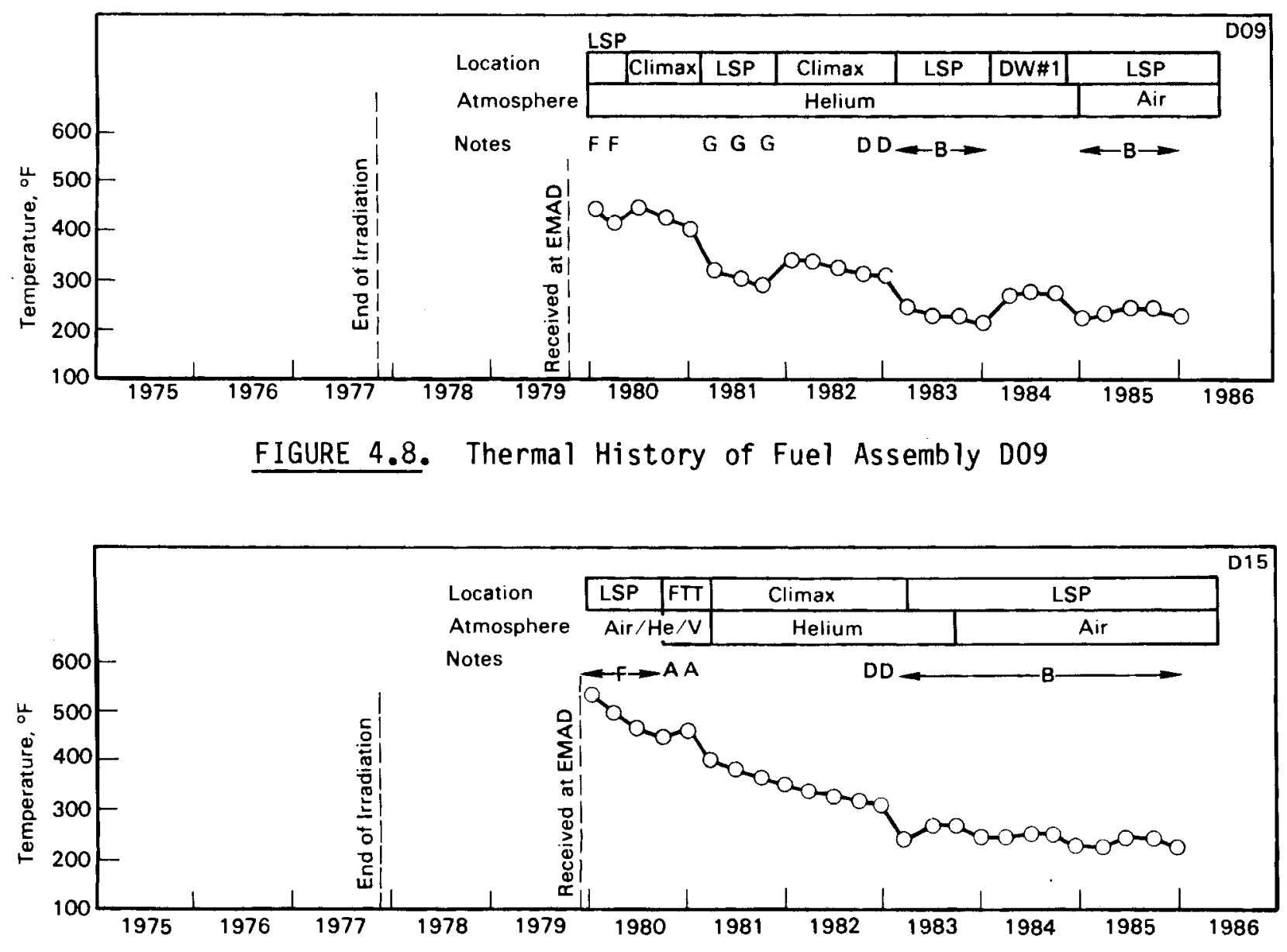

FIGURE 4.9. Thermal History of Fuel Assembly D15 (V = Vacuum). Not shown are maximum cladding temperatures up to $680^{\circ} \mathrm{F}\left(360^{\circ} \mathrm{C}\right)$ during brief calibration tests. 


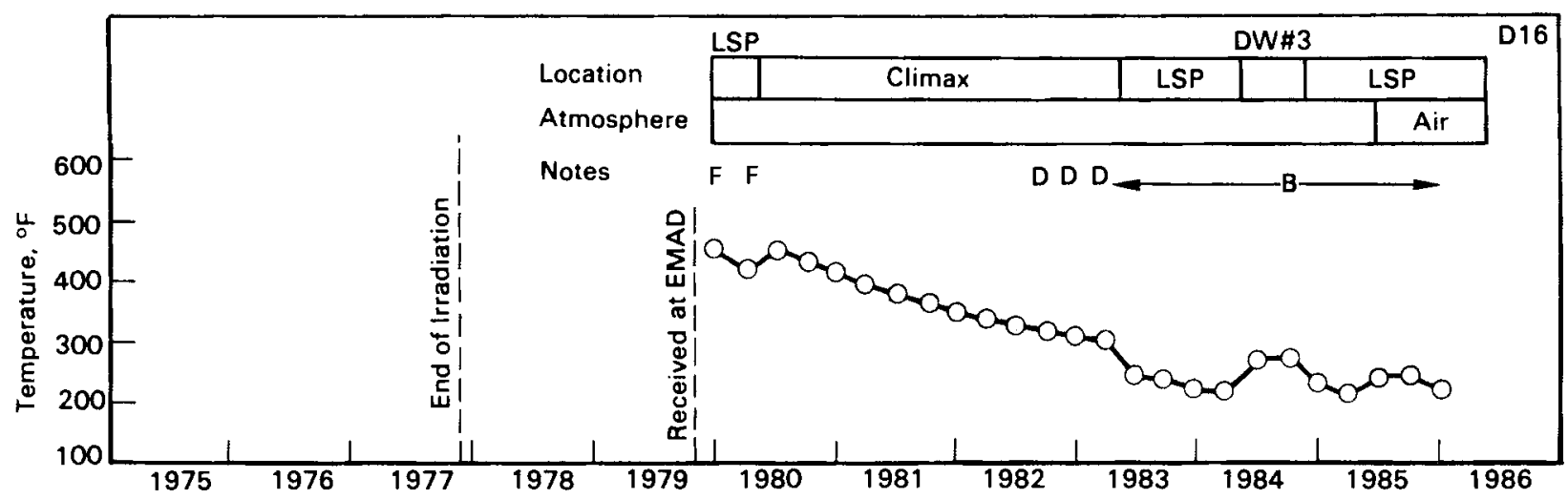

FIGURE 4.10. Thermal History of Fuel Assembly D16

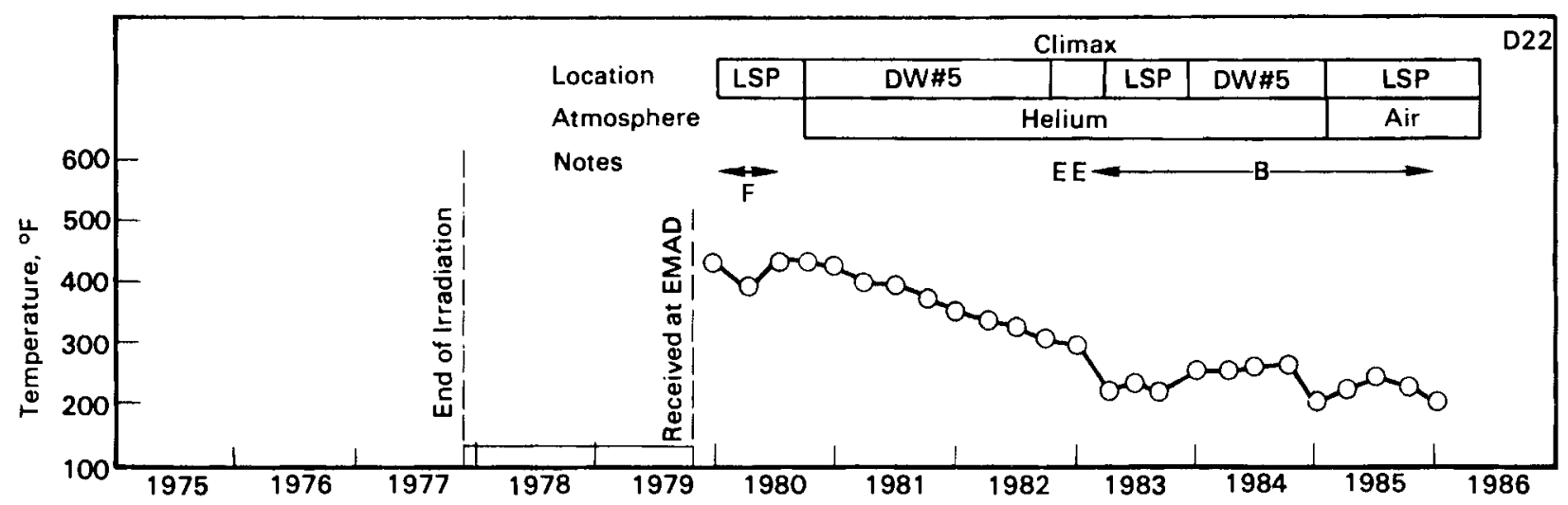

FIGURE 4.11. Thermal History of Fuel Assembly D18

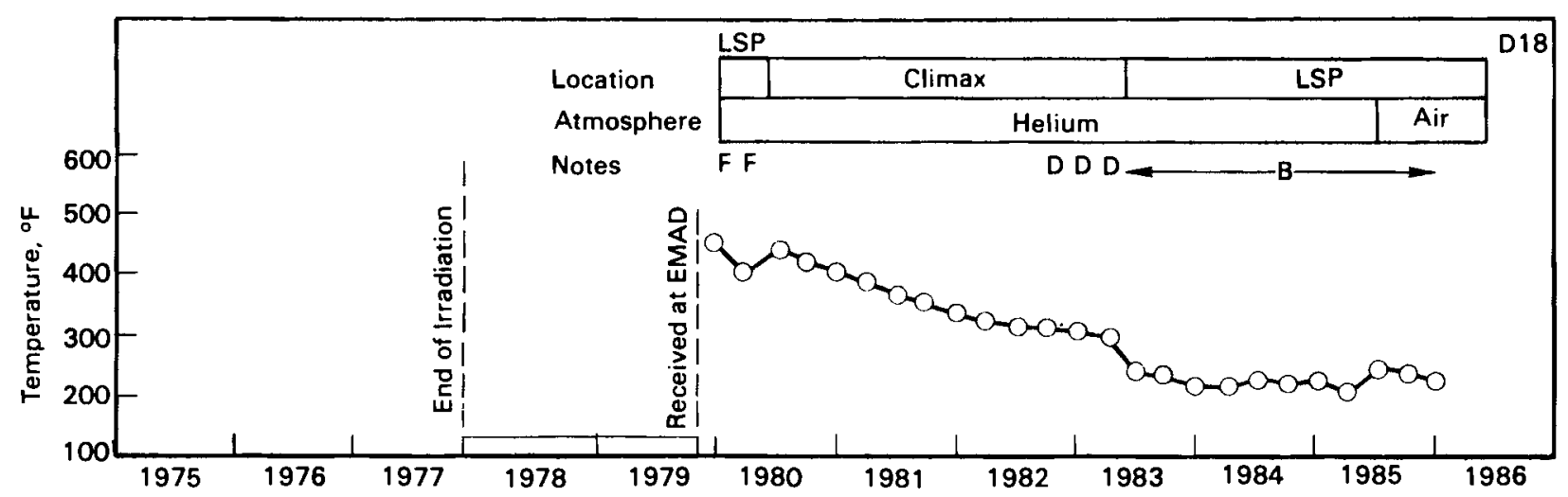

FIGURE 4.12. Thermal History of Fuel Assembly D22 


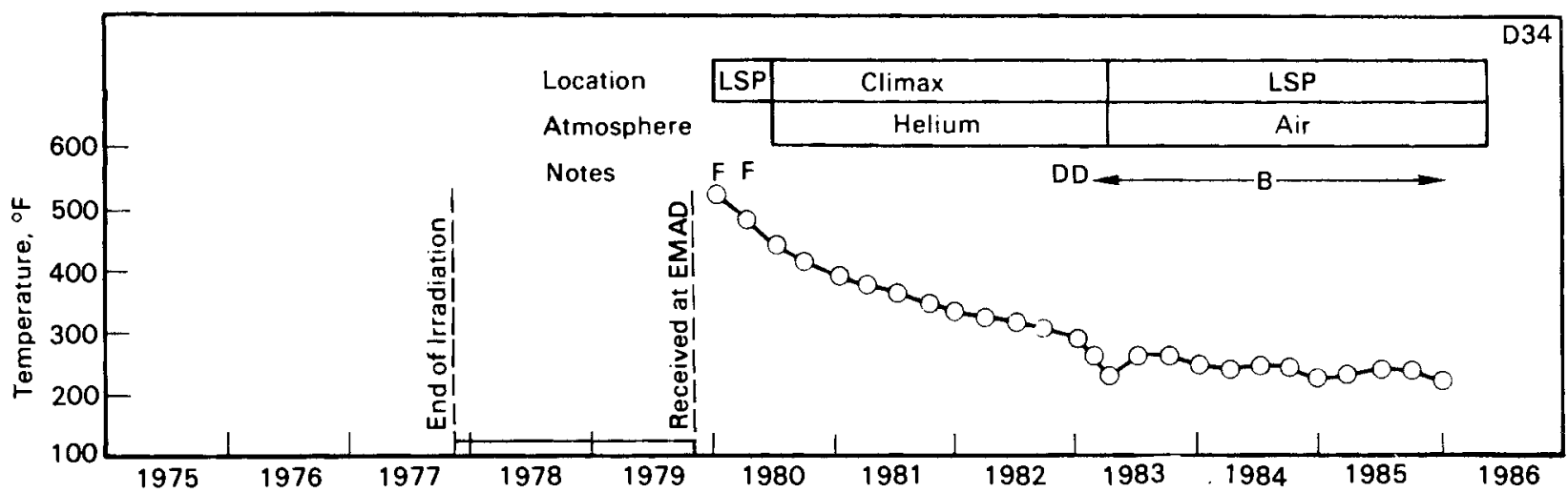

FIGURE 4.13. Thermal History of Fuel Assembly D34

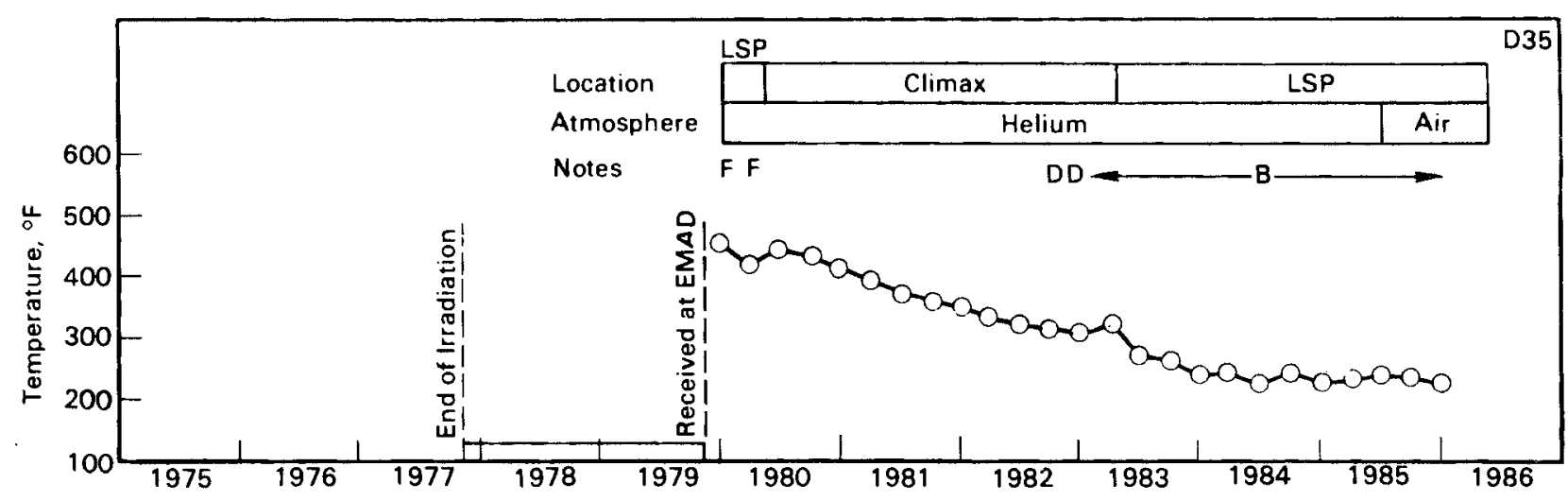

FIGURE 4.14. Thermal History of Fuel Assembly D35

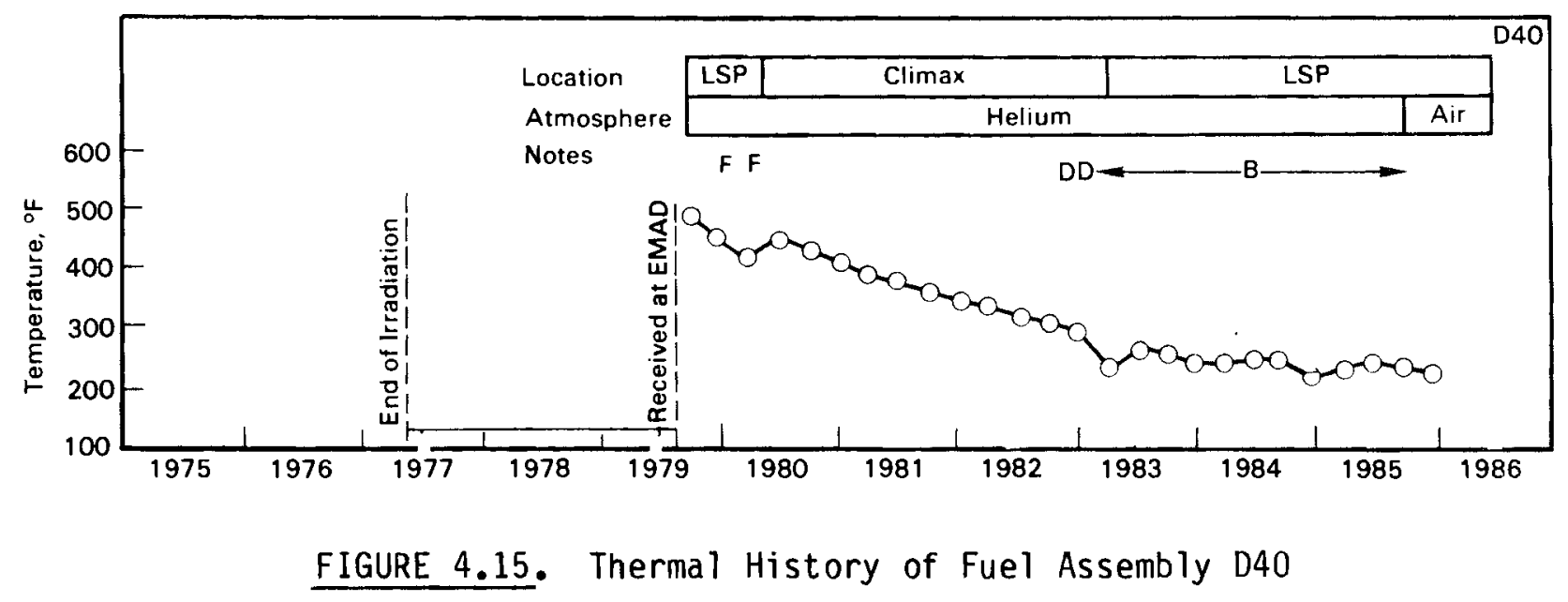




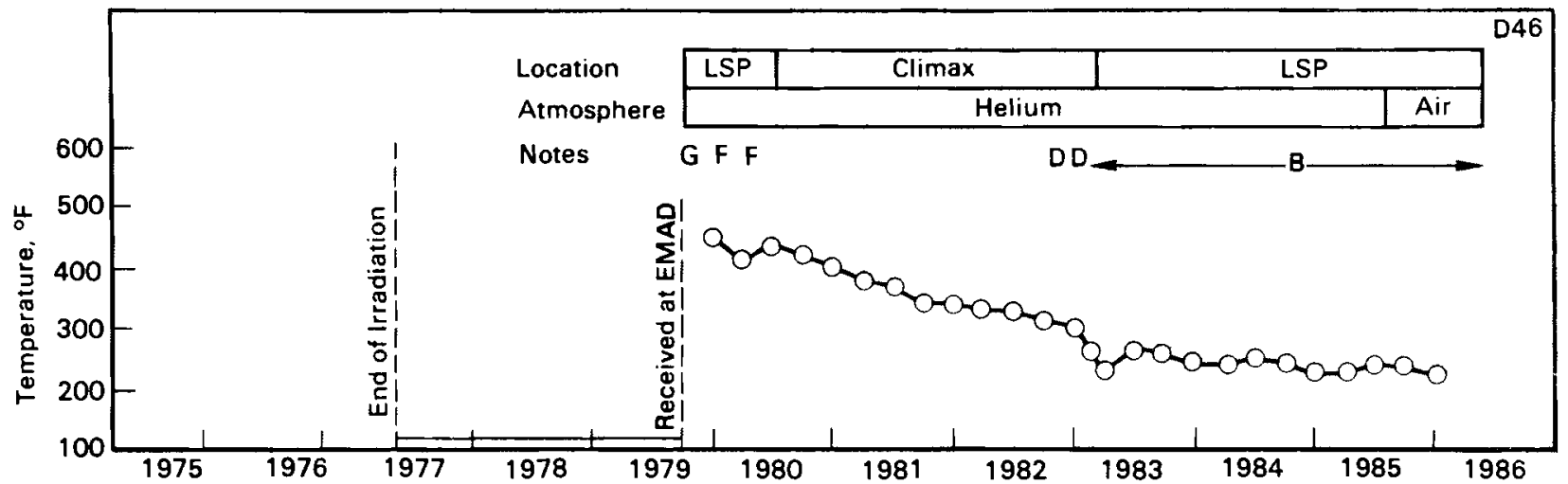

FIGURE 4.16. Thermal History of Fuel Assembly D46

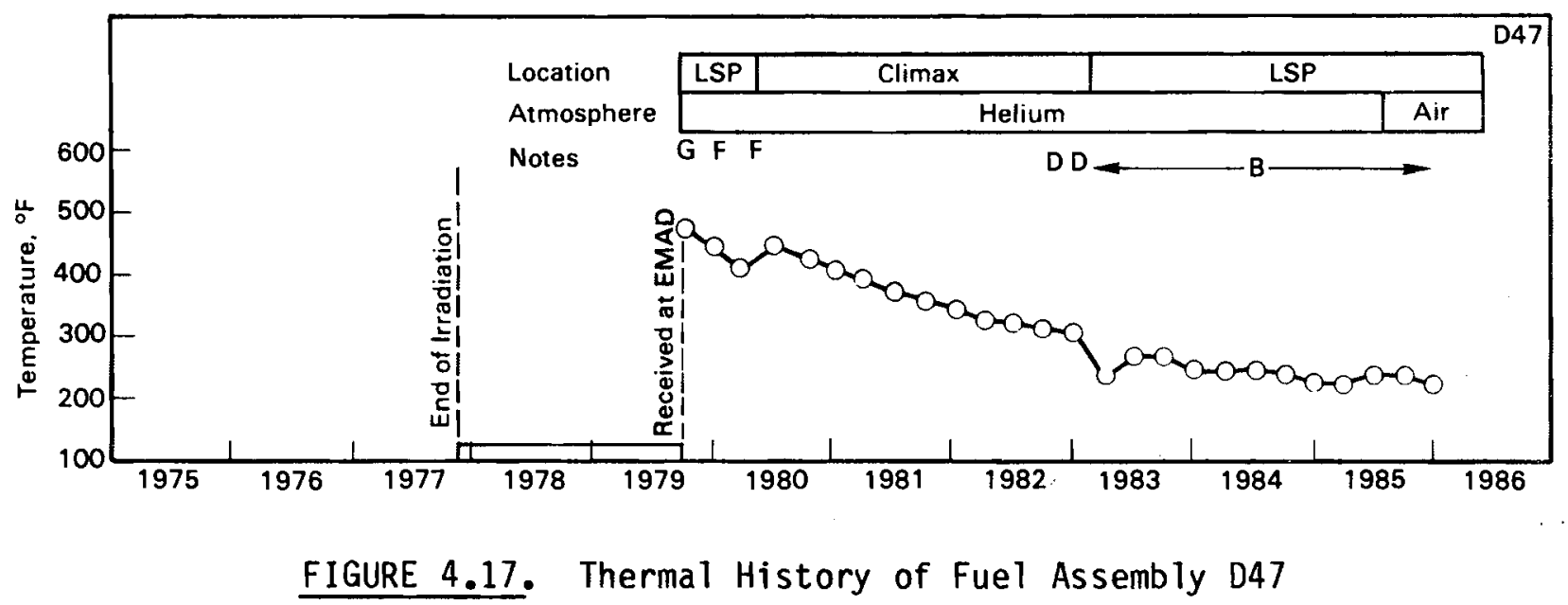




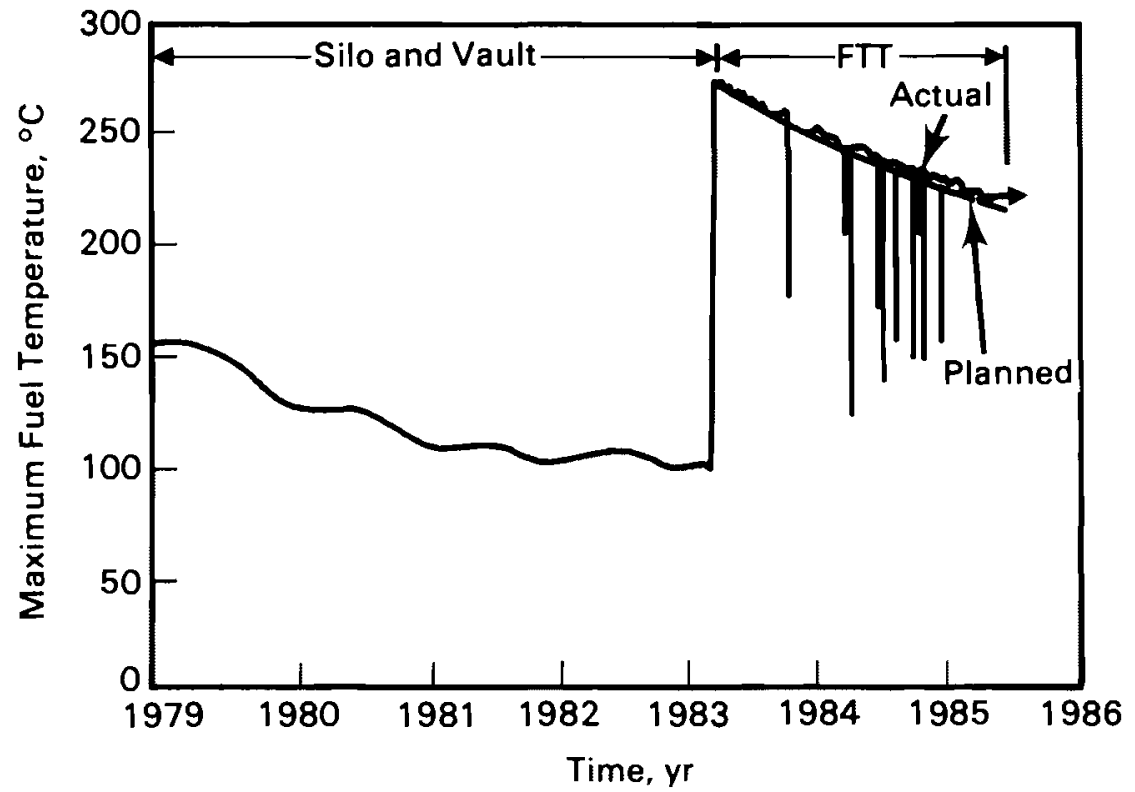

FIGURE 4.18. Fuel Cladding Temperatures for Fuel Assembly B02 During Dry Storage Tests at EMAD 


\subsection{FUEL INTEGRITY MONITORING}

The integrity of the spent fuel cladding was monitored during the dry storage program by visual inspections, the analyses of canister gas samples, and analyses of surface contamination swipes obtained from fuel surfaces and associated equipment used during processing and storage.

\subsection{MONITORING OF GAS SAMPLES}

At the times indicated in Table E.1 in Appendix E, 500-mL gas samples were removed from the canisters containing the individual spent fuel assemblies. The procedure used to obtain the samples depended on the canister and type of test in progress and are described in detail by Unterzuber et al. (1982). The procedures used for the unwelded (air atmosphere) canisters, the encapsulated canisters (He), and the FAITM canisters (air/He/vacuum) are briefly described.

\subsubsection{Sampling Method for Unwelded Canisters}

Four fuel assemblies used for the SFT-C program were placed in canisters without evacuation, helium backfill, or seal welding. A mechanical sealed evacuation/backfill port was provided on each canister for future use for canister evacuation and helium backfill during subsequent encapsulation. This port was used for gas sampling by quickly removing the cap and affixing a sampling tree consisting of a manifold, two $500-\mathrm{mL}$ sample bottles and a vacuum gage attached to the manifold. Bellows-operated valves were provided at the inlet of the manifold and between the manifold and each sample bottle. Before drawing a sample, the bottles were baked out at a temperature of $400^{\circ} \mathrm{F}\left(205^{\circ} \mathrm{C}\right)$ during evacuation. The tree and sample bottles were then evacuated to $10^{-7}$ torr. Following attachment to the port, the manifold valve was opened, and then the sample bottle valves were closed after the vacuum gage stabilized. The port was then resealed. The samples were analyzed for radionuclides and composition in laboratory facilities at both NTS and the LLNL.

\subsubsection{Sample Method for FAITM Test Canister}

To sample the internal atmosphere of the canister while it was installed in the FAITM apparatus, tubing was installed connecting the port on the 
canister lid to an adjacent hot cell. The sampling equipment consisted of a manifold to which four $500 \mathrm{~mL}$ sample bottles and two vacuum purge bottles, each of 1 gallon capacity, were connected through isolation valves. Before use, the purge and sample bottles were evacuated. To draw a sample, the first purge bottle isolation valve was opened to draw the residual gasses from the sample line into the bottle. When the pressure in the sample manifold stabilized, the purge bottle was closed off and the valves on the first two sample bottles were opened, and then closed. The same procedure was repeated with the second purge bottle and the remaining two sample bottles. The sample bottles were then sent to the laboratory for analysis. No differences within limits of detectability were found between sets of samples.

Four sampling techniques were used during the high-temperature tests on fuel assembly B02 using an air atmosphere in the canister. During the first 6 months, samples were taken without replacing the removed gas. During months 7 to 15, the canister was vented after the samples were taken to allow the canister to return to atmospheric pressure. For months 15 to 22, the entire system atmosphere was evacuated through a 0.45-micron filter; and after samples were collected, the system was vented to the atmosphere. During month 23 , the system was held at -200 torr gage for six days and sampled, held at -300 torr gage for 4 days and sampled, and held at -400 torr gage and sampled. The system atmosphere was then evacuated and replaced with fresh air, and the 14-day sampling cycle completed. This method of sampling was used to characterize the nature and size of the fuel rod breach by observing the Krypton-85 release rates at different system pressures. At month 24 , the system atmosphere was exchanged; gas samples were collected before and after the exchange.

\subsubsection{Sample Method for Sealed Drywell and SFT-C Canisters}

The apparatus used to sample the gas from the seal-welded, evacuated, and helium backfilled canisters was similar to that used for the unwelded canisters, except for the use of an additional fixture bolted to the canister lid that allowed the cap to be removed from the evacuation/backfill port in a vacuum to prevent contamination of the canister gas. Before sampling, the sample bottles were baked out at $400^{\circ} \mathrm{F}\left(205^{\circ} \mathrm{C}\right)$ under $10^{-7}$ torr vacuum. The manifold and the internal volume of the fixture were flushed with helium and 
evacuated to less than 1 millitorr. The cap on the canister lid was removed, allowing the gas in the canister to fill the fixture. The valves on the manifold and sample bottles were opened and then closed to isolate the sample. The evacuation chamber was recharged with helium following gas sampling and before the canister lid port connection was resealed. The sample bottles were returned to the laboratory for analysis.

\subsubsection{Gas Sample Analys is}

The canister atmosphere samples were analyzed for krypton-85 by laboratories at NTS and LLNL using methods capable of detecting concentration levels of $1 \times 10^{-6}$ microcuries per cubic centimeter of sample. Other radioactive gases may have been present, but they would be at concentrations below limits of detection due to decay. The full volume gas samples were analyzed by gamma spectometry to determine which radioisotopes were present. The isotopes of principal interest were strontium-90, cesium-37 and cobalt-60. Possible sources of these radioisotopes could be from rod breaches or from aerosols or particulates generated by the drying of activated reactor crud deposited on the fuel during exposure in the reactor. The gamma spectroscopy method utilized was capable of detecting less than 1 microcurie of the fission or activation products mentioned above.

\subsubsection{Results of Gas Sample Monitoring Program}

The results of the gas sample analyses taken on the various spent fuel assemblies during the period from 1980 to 1985 are summarized in Table E.1 in Appendix E. Fuel assembly B02 was subject to more frequent monitoring during 1983 to 1985 as part of the FTT program; the results are given in Table E.2.

The summary shown in Table E.1 indicates that the levels of krypton-85 in the cover gas of all canisters except B41 remained at background levels throughout the period of the program. The cover gas from fuel assembly B41 showed an activity several orders of magnitude higher initially (8/5/80), but this was not confirmed by the results from a second laboratory. Additional samples analyzed between 8/11/83 and 11/19/84 all showed high levels of krypton-85 in analyses performed by both laboratories. Based on these analyses, it was concluded that one or more rods in this fuel assembly were leaking. Cesium 
was detected in water drawn from a shipping cask used to transport B41 from the Turkey Point Reactor to $\mathrm{BCL}$, suggesting one or more leaking rods. The presence of a cladding defect was not confirmed by visual examination at BCL, but only a small fraction of the rod surfaces were observable. After $11 / 19 / 84$, the levels of krypton returned to background levels as the fission gases in the leaking rod(s) were depleted. Based on this combined evidence, it was concluded that B41 had a small defect or leak in one or more rods prior to encapsulation at EMAD.

The results of the gas analysis on fuel assembly B02 during the FTT program, shown in Figure E.2, indicates a cladding failure while the dry storage test was in progress. During the second month of the test, the gas samples showed increases in $\mathrm{CO}_{2}$, a small decrease in $\mathrm{O}_{2}$, and detectable concentrations of $\mathrm{N}_{2} \mathrm{O}$. It was postulated that the source of carbonaceous material for the formation of the $\mathrm{CO}_{2}$ was from surfaces within the system. The carbon-14 content of the $\mathrm{CO}_{2}$ gas was postulated to have originated from reaction of oxygen with carbon-14 at the surface of the Zircaloy fuel cladding (Van Konynenburg 1986). The $\mathrm{N}_{2} 0$ was probably the product of the gamma irradiation of air. During the third month of the test, the krypton- 85 increased by five orders of magnitude, indicating that a cladding breach had occurred. The He concentration also increased significantly. Analysis of rates of release of these gases (Johnson et al. 1985) suggested that the size of the cladding breach was approximately 0.3-um equivalent diameter. Comparisons of the release rates of He and krypton-85 suggested that the breach was in the form of microcracks. Such cracks may have been produced by stress corrosion cracking or by other undefined reasons. As the test progressed, the krypton-85 levels decreased as the gases in the rod were depleted through leakage, and they did not return to original levels. The gas samples also showed depletion of oxygen early in the test, apparently explained by a concomitant increase in carbon dioxide concentrations.

Stress rupture calculations reported by Johnson et al. (1985) showed that the stresses and temperatures were too low to expect breaches to form in 
Time Scale for Assembly B41, yr

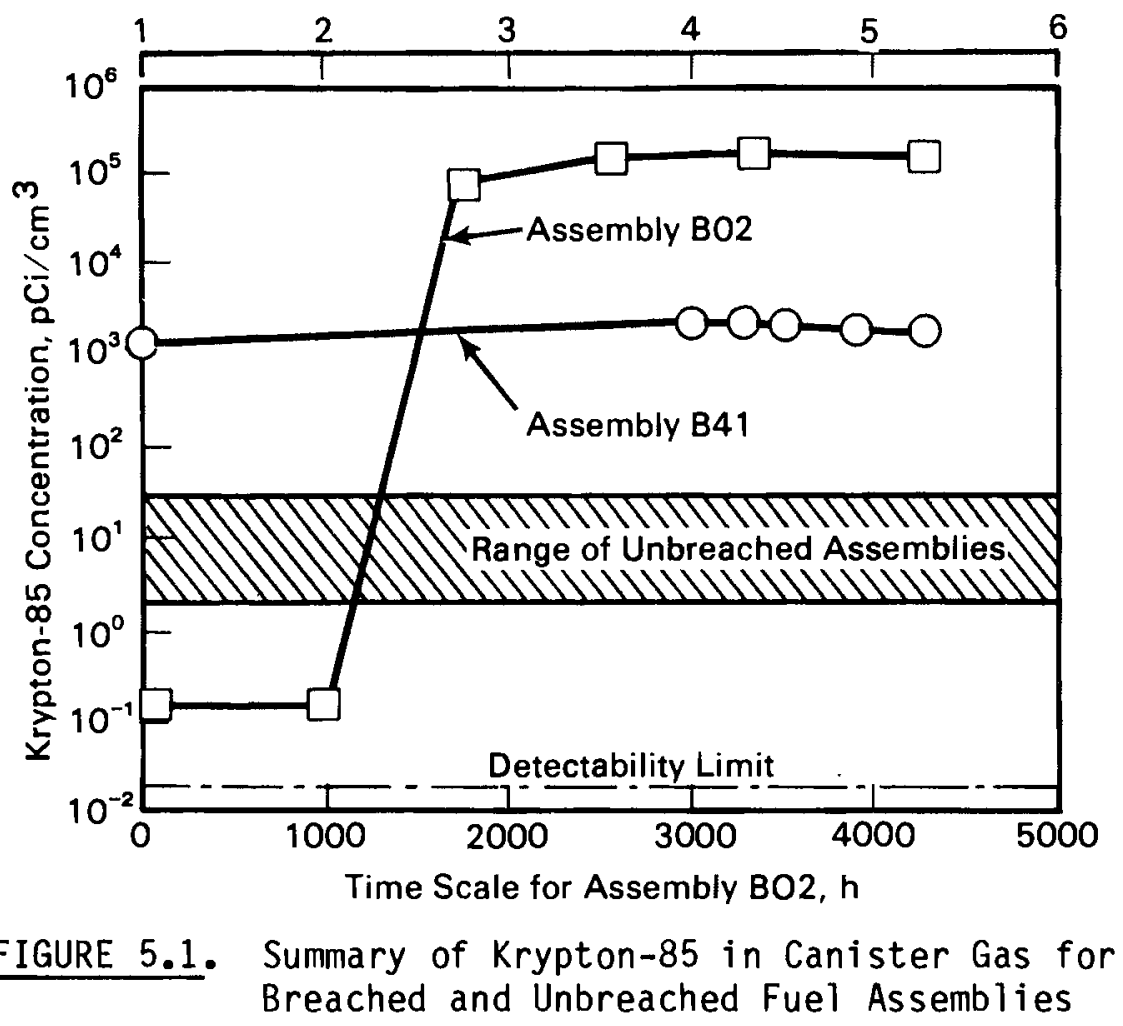

defect-free cladding; it was theorized that the breach may have occurred in a fuel rod weakened by an incipient cladding or end cap defect. Calculations suggested that a defect $\sim 90 \%$ through-wall would be required to result in crack propagation under conditions estimated to apply to the rod. Chemical effects of fission products and/or delayed hydrogen cracking cannot be fully ruled out without examination of the failure site.

The relative concentrations of krypton-85 in the cover gases of both the breached and unbreached rods is presented in Figure 5.1. The time scale is referred to the start of the FTT for B02 and approximately to the arrival of the fuel assemble at NTS for the case of B41. It is apparent from an examination of this figure that the analysis of krypton- 85 in the cover gas is a sensitive indicator of the presence of a breached rod. 


\subsection{SURFACE CONTAMINATION SWIPES}

Fuel assemblies stored at EMAD in unwelded canisters were checked for changes in radioactive inventories by fuel rod surface swiping on a semiannual basis. Swipe samples were taken on at least three regions of the fuel assembly, near the top, center, and bottom of the fuel. Surface radioactivity on fuel assemblies stored in welded canisters was analyzed by swiping when canisters were cut open for other programmatic reasons. On these assemblies, swipes were taken on at least six of the eight axial regions of three fuel assembly faces. The swiping was performed by wiping each rod in the region identified in the test procedure with a 47-mm dia \#2 Whatman filter paper mounted on a soft-back holder using a master-slave manipulator. On fuel assembly $\mathrm{B} 02$, surface radiation analys is was conducted prior to the FTT by swiping specified rods on three regions of three assembly faces. Swipes were taken on the center rod of each of the four faces in three specified regions; also, swipes were taken across all 15 rods on each side of the fuel assembly at one axial location. Post-test contamination was characterized by performing seven swipes at various specified locations on one face.

Swipes were analyzed by dissolving the filter paper in acid, diluting the solutions to sufficiently reduce activity level, and then counting the samples with a high efficiency Ge-Li scintillation counter.

Following canister cutting operations and fuel assembly removal, contamination on canister interior surfaces was also investigated. This investigation was accomplished by taking contamination swipes of the canister interior, and by collecting and counting loose residue from inside the canister. Locations swiped included 1) the upper surface of the lower cruciform upon which the fuel assembly rested, 2) a 2-ft length of 1 fuel assembly guide rail, 3) approximately 10 square inches of the canister side wall adjacent to the cut, and 4) approximately 10 square inches of the side wall near the bottom of the canister. The method of swiping and the analysis of the swipes was similar to that used on the fuel assemblies.

The fuel contamination characterization swiping procedures produced voluminous data on the level and nature of the contamination. Table E.3 in Appendix $E$ summarizes these data by providing the maximum activity of each 
detected species measured during the analysis of each stated fuel on the stated date. Table E.4 summarizes the canister contamination swipe and residue data.

The data did not show clear patterns. In general, there was a reduction in activity with successive swipes at each location because surface contamination was removed by the swiping action. Assembly $\mathrm{B} 02$, which is known to have suffered a breach during the FTT, also showed no consistent pattern of surface contamination. Although gross beta activity showed a small excursion, the cobalt-60 activity decreased, only to increase to pre-FTT levels during the terminal inspection at EMAD.

It was concluded that although the breached rods leaked highly detectable quantities of gases, they did not leak significant amounts of particulate material that could be detected through the analysis of swipes of fuel and canister surfaces. 
. 


\subsection{CONDITION OF THE EMAD FACILITY FOLLOWING TESTING}

During decommissioning of the EMAD facilities and following removal of spent fuel from the site, the test locations utilized in the Spent Fuel Handling and Packaging (SFHP) Program were examined for mechanical/thermal degradation and contamination. This section describes the results of these examinations.

\subsection{DRYWELLS}

Examination of the drywells was completed in April 1986, and no evidence of physical change or damage was found. During testing, the general radiation level above the shield plug was less than $0.1 \mathrm{mrem} / \mathrm{h}$ (Johnson 1983). After removal of the fuel from the drywells, swipes were taken on all interior surfaces and they were found to be free of contamination. Test areas were declared "non-control" areas. Water from condensation of moisture in the air was found under each drywell lid. The moist air entered through the instrumentation pipe and ineffective sealing at the cover faces. Some oxidation of painted surfaces was apparent, but this was considered normal for outdoor locations.

Concrete spalling at the cover plate seal was a continuing problem during testing. Such spallation is not unusual for shallow patched areas and was not considered a serious situation. Probably, it could have been eliminated if more suitable patching materials and method of patch application were used.

\subsection{CONCRETE SILO}

The north silo experienced failures of the strain gage instrumentation immediately after construction and was not used in the testing program. The cause of the failures was determined to be chemical incompatibility of the strain gage protective covering with the high-alkali concrete. This was confirmed by laboratory testing performed by the vendor. The No. 2 (south) silo was used for spent fuel demonstrations for 40 months. Improved strain gage sensors were installed in the south unit during early testing and no subsequent instrumentation problems were encountered with this unit. 
Examination of the south silo did not reveal any structural defects resulting from spent fuel storage. The unit was moved two times between the storage location and the hot bay without incident. Generally, radiation at the silo wall (eye level) was $0.3 \mathrm{mrem} / \mathrm{h}$ or less during testing (Johnson, Gilbert, and Guenther 1983). Following fuel removal, radiation surveys indicated no contamination, and the unit was considered suitable for unrestricted access and use.

\subsection{AIR-COOLED VAULT (LAG STORAGE PIT)}

Examination of the storage vault revealed no degradation as a result of spent fuel storage and handling activities. Radiation surveys have indicated no contamination. Radiation surveys in July 1986 also showed no contamination present, and no further decontamination effort was considered necessary for plant shutdown.

Normal free convective air circulation was adequate to cool all fuel assemblies. The forced ventilation system was used only during testing of that system and was not needed during the passive storage period.

\subsection{FINAL FUEL EXAMINATIONS AT EMAD}

Visual and photographic examinations of the 17 spent fuel assemblies were performed during shipping cask loading prior to transportation to INEL. These examinations did not reveal any visible damage or physical change. The deposits adhering to the fuel pins and supports had the same general appearance as when the fuel was delivered to EMAD. However, these deposits appeared to have a slightly more reddish hue than when delivered. This color change may have been due to spinel oxidation (e.g., $\left.\mathrm{Fe}_{x} \mathrm{Ni}(3-\mathrm{x})^{\mathrm{O}_{4}}\right)$ to hematite $\left(\mathrm{Fe}_{2} \mathrm{O}_{3}\right)$ during exposure to air. Photographs of the top, center, and bottom regions of fuel assembly B02 showing the three principal types of deposits described in Section 3.1 are shown in Figures 3.1, 3.2, and 3.3. The clean areas resulted from removal of the deposits from the zirconium oxides by surface contamination swipes. 
Transfers from the lag storage pit, removal from the canisters, and shipping cask loading were accomplished without incident. Contamination control during cask loading was adequate, and no delays were incurred for decontamination activities.

\subsection{SUMMARY OF RESULTS OF FINAL EXAMINATIONS}

No physical degradation or contamination of the EMAD dry storage locations occurred as a result of the spent fuel storage testing, because the fuel was encapsulated before emplacement. Visual examination of the 17 fuel assemblies during transfer from the canisters to the shipping casks at the conclusion of the program revealed no significant changes or damage from handling and storage. 


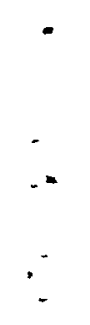




\subsection{OPERATIONAL OBSERVATIONS}

The EMAD hot bay facilities were satisfactory for all handling and related storage testing associated with this program, including encapsulation, transportation of fuel canisters, cover gas sampling, surface contamination (swipe) analysis, inspection, and calorimetry. However, during the course of this program, several unanticipated events and experiences were encountered and resulted in the following lessons learned:

1. The electrical and pneumatic control lines to the fuel grapple in the EMAD hot bay presented several problems. These lines tended to become entangled with fixtures, stands, and equipment, and the variable loads exerted on the grapple by these lines changed the vertical alignment of the fuel assembly during canister and cask insertion operations. Before each operation, careful planning and equipment arrangement was required to avoid these problems.

2. The canister was attached to the concrete shield plug assembly by means of four support pins that were threaded into the shield skirt assembly as shown in Figure 3.6. Canister support pin removal for demounting the shield plug was occasionally encumbered by galling of the threads on these pins. Two means were used to reduce this problem. First, an anti-sieze lubricant was used on the threaded surfaces before installation of the pins. Second, a slight lifting effort was applied to the shield plug with the crane during pin removal to reduce the load on the threads. To facilitate the application of the proper lifting effort, a method of accurately reading out the applied crane loading would have been useful, but was not available. When galling occurred, a remotely operated milling machine was required to remove the plugs.

3. The canister cutting machine experienced some problems with blade breakage. The problem was reduced by the careful 
adjustment of the vertical alignment of the canister and by reducing the travel speed below the manufacturer's recommendations.

4. During calorimeter tests some contamination of the surroundings resulted from fuel crud carried by steam emissions during fuel assembly immersion and removal. This problem was reduced by installing an evacuation system consisting of a Roots blower, a cyclone separator, and a HEPA filter system. The emissions were drawn off by the blower through an annular yoke mounted above the calorimeter opening; any particulates present were removed in the separator and filter system.

5. During performance of the FTT, some darkening occurred in the shield window glass in the process cell. This darkening could have been reduced if removable lead shielding was used or if a dielectric discharge grounding system was installed to protect the facility shield windows.

6. Fuel canisters were refurbished and reused, thereby effecting considerable cost savings to the project. Only a minor decontamination effort was required to enable the removal of the lid seal weld, refitting the $1 \mathrm{id}$, and rewelding it in a contamination control area with manual T.I.G. procedures.

It is recommended that the lessons learned in this program be considered in future spent fuel storage and handling activities. 


\subsection{CONCLUSIONS}

Between 1978 and 1986, 17 spent PWR fuel assemblies were encapsulated in stainless steel canisters, subjected to dry storage test demonstrations, and retrieved at the NTS. The dry storage demonstration and test methods included 1) surface drywells in the soil at EMAD; 2) deep drywells in a granite formation at the Climax site, 3) a concrete silo, 4) an air-cooled vault, and 5) an electrically-heated test module (FAITM). In these tests, peak fuel cladding temperatures were as follows:

- surface drywells

- deep drywells

- concrete silo (canister)

- vault (lag storage)

- Fuel Temperature Test (FTT)

$\begin{array}{lll}\frac{{ }^{\circ} \mathrm{F}}{452} & & \frac{{ }^{\circ} \mathrm{C}}{233} \\ 452 & & 233 \\ 334 & & 168 \\ 532 & & 278 \\ 527 & & 275\end{array}$

During this entire program, only one fuel rod out of the 3468 rods tested developed a cladding breach (Johnson et al. 1986). The fuel assembly (B02) containing the breached rod was stored in the concrete silo for 3.5 years and in the dry storage vault for 0.5 years prior to 24 months of testing at temperatures declining from 527 to $430^{\circ} \mathrm{F}\left(275\right.$ to $\left.222^{\circ} \mathrm{C}\right)$. The breach was detected during testing of the encapsulated fuel in air. The breach was signaled by an increase, by several orders of magnitude, in the concentration of krypton-85 in the canister atmosphere and by a simultaneous increase in helium in the air cover gas. Differences in the release rates of krypton and helium from the breached rod suggested that the breach geometry consisted of fine cracks. The measured ${ }^{85} \mathrm{Kr}$ and helium inventories corresponded approximately to calculated concentrations for failure of a single rod, based on fission gas release measurements on similar Turkey Point fuel rods and on the amount of helium fill gas injected during rod fabrication. Several possible explanations were postulated. A leading postulate was that the breach occurred at the site of an incipient defect that was present before the dry storage test. Pretest eddy current inspection of five rods from this assembly indicated that incipient defects were indeed present. One other fuel assembly (B41) was also determined 
to contain one or more breached rods before testing by wet sip testing the shipping cask cooling water. The presence of breached rod(s) provided no particular handling problems during the course of the demonstration testing.

The analysis of the storage atmosphere provided a very sensitive method for determining the presence of a breached rod during dry storage. The analysis of contamination swipes did not confirm the presence of a cladding breach because the small size restricted the release of particulate contamination. Determination of the extent of fuel oxidation from the analysis of oxygen depletion was inconclusive because the small calculated size of the breach would restrict the amount of oxygen reacting with the fuel to an insignificant amount in comparison with the total oxygen inventory of the canister.

At the conclusion of the program, examination of the EMAD storage locations revealed no degradation or contamination of the storage facilities as a result of the demonstration test. It was possible to decommission these facilities without special decontamination activities because the fuel assemblies were encapsulated prior to emplacement. The hot cell area was contaminated by fuel crud removed from assemblies during calorimetry. 


\section{REFERENCES}

Atkin, S. D. 1981. Destructive Examination of 3-Cycle LWR Fuel Rods from Turkey Point Unit 3 for the Climax-Spent Fuel Test. HEDL-TME 80-89, Westinghouse Hanford $\mathrm{Co} ., \mathrm{Richland}$, Washington.

Blackburn, L. D., D. G. Farwick, S. R. Field, L. A. James, and R. A. Moen. 1978. Maximum Allowable Temperature for Storage of Spent Nuclear Reactor Fuel, HEDL-TME-78-37, Westinghouse Hanford Co., Richland, Washington.

Brough, W. G., and W. C. Patrick. 1982. Instrumentation Report 1: Specification, Design, Calibration and Installation of Instrumentation for an Experimental, High-Level, Nuclear Waste Storage Facility. UCRL-53248, Lawrence Livermore National Laboratory, University of California, Livermore, Cal ifornia.

Chin, B. A., M. A. Khan, and J. C. L. Tarn. 1986. Deformation and Fracture Map Methodology for Predicting Cladding Behavior During Dry Storage. PNL-5998, Pacific Northwest Laboratory, Richland, Washington.

Creer, J. M., and J.W. Shupe, Jr. 1981. Development of a Water Boil-0ff Spent Fuel Calorimeter System. PNL-3434, Pacific Northwest Laboratory, Richland, Washington.

Davis, R. B. 1980. Data Report for the Non-Destructive Examination of Turkey Point Spent Fuel Assemblies B02, B03, B17, B41 and B43. HEDL-TME 79-68, Westinghouse Hanford Co., Richland, Washington.

Davis, R. B., and V. Pasupathi. 1981. Data Summary Report for the NonDestructive Examination of Rods G7, G9, J8, I9, and H6 From the Turkey Point Fuel Assembly B17. HEDL-TME 80-85, Westinghouse Hanford Co., Richland, Washington.

Davis, R. B. 1981. Pre-Test Nondestructive Examination Data Summary Report on Turkey Point Spent Fuel Assemblies D01, D04, and D06 for the Climax-Spent Fuel Test. HEDL-TME 80-83, Westinghouse Hanford Co., Richland, Washington.

Dobbins, J. C. 1983. Histories of Spent Nuclear Fuel Assemblies while at the EMAD Facility (December 1978 through September 1982). DOE/NV/10250-6, Department of Energy, Washington, D.C.

Einziger, R. E., S. H. Atkin, D. E. Stellrecht and V. Pasupathi. 1982. "High Temperature Postirradiation Materials Performance of Spent Pressurized Water Reactor Fuel Rods Under Dry Storage Conditions," Nuclear Technology. $57: 65-80$.

Einziger, R. E., and R. V. Strain. 1986. 0xidation of Spent Fuel at Between 250 and $350^{\circ} \mathrm{C}$. EPRI NP-4524, Electric Power Research Institute, Palo Alto, California. 
Johnson, A. B., E. R. Gilbert and R. J. Guenther. 1983. Behavior of Spent Nuclear Fuel and Storage System Components In Dry Interim Storage, PNL-4189 Rev.1, Pacific Northwest Laboratory, Richland, Washington.

Johnson, A. B., E. R. Gilbert, J. C. Dobbins, D. R. Oden, D. L. Stidham, and J. E. Garnier. 1985. "Simulated Dry Storage Test of a Spent PWR Nuclear Fuel Assembly in Air," In Proceedings of the Symposium on Waste Management, University of Arizona, Tucson, Arizona.

Johnson, A. B. Jr., E. R. Gilbert and J. C. Dobbins. 1986. "Evaluation of a PWR Fuel Assembly Subject to Air Storage," In Proceedings of the Third International Spent Fuel Storage Technology Symposium/Workshop, pp. W55-W62, CONF-860417. PNL-SA-13878, Pacific Northwest Laboratory, Richland, Washington.

Patrick, W. C., L. B. Ballou, T. R. Butkovich, R. C. Carlson, W. B. Durham, G. L. Hage, E. L. Majer, D. N. Montan, R. A. Nyholm, N. L. Rector, D. G. Wilder, and J. L. Yow, Jr. 1981. Spent Fuel Test-Climax: Technical Measurements Interim Report Fiscal Year 1981. UCRL-53294, Lawrence Livermore National Laboratory, University of California, Livermore, California.

Patrick, W. C., L. B. Ballou, T. R. Butkovich, R. C. Carlson, W. B. Durham, G. L. Hage, E. L. Majer, D. N. Montan, R. A. Nyholm, N. L. Rector, D. G. Wilder, and J. L. Yow, Jr. 1982. Spent Fuel Test-Climax: Technical Measurements Interim Report Fiscal Year 1982. UCRL-53294-82, Lawrence Livermore National Laboratory, University of Cal ifornia, Livermore, California.

Patrick, W. C., L. B. Ballou, T. R. Butkovich, R. C. Carlson, W. B. Durham, G. L. Hage, E. L. Majer, D. N. Montan, R. A. Nyholm, N. L. Rector, D. G. Wilder, and J. L. Yow, Jr. 1984. Spent Fuel Test-Climax: Technical Measurements Interim Report Fiscal Year 1983. UCRL-53294-84, Lawrence Livermore National Laboratory, Livermore, Cal ifornia.

Unterzuber, R., R. D. Milnes, B. A. Marinkovic, and G. M. Kubancsek. 1982. Spent Fuel Dry Storage Testing at EMAD (March 1978 through March 1982). PNL-4533, Pacific Northwest Laboratory, Richland, washington.

Unterzuber, R. 1981. Fuel Temperature Measurements Under Imposed Dry Storage Conditions (1.4 KW PWR Spent Fuel As sembly). D0E/NV/10171-4.

Van Konynenburg, R. A., C. F. Smith, H. W. Culham, and H. D. Smith. 1986. "Carbon-14 in Waste Packages for Spent Fuel in a TUFF Repository." In Proceedings of Scientific Basics for Nuclear Waste Management. Materials Research Society, Boston, Massachusetts. 
APPENDIX A

HANDLING HISTORIES OF SPENT FUEL ASSEMBLIES 


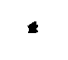

$\ldots$
$\therefore$
$\therefore$ 
HANDLING HISTORY OF FUEL ASSEMBLY BO2

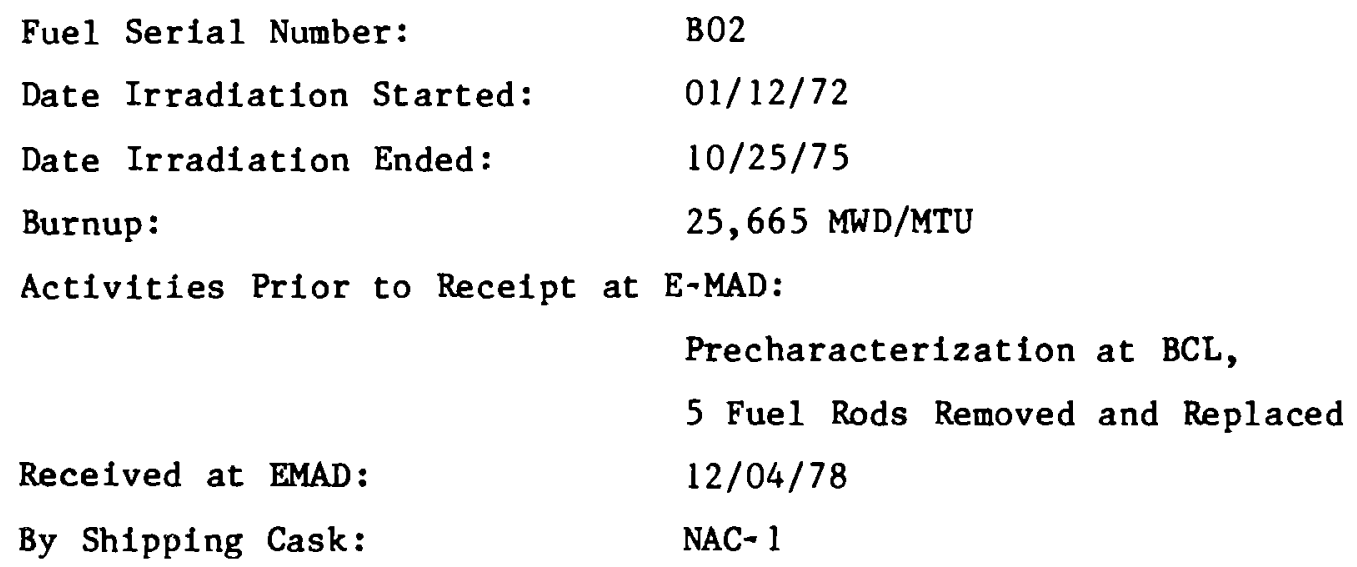


FUEL ASSEMBLY BO2

DATE

$07 / 13 / 82$

Silo returned to Hot Bay, canister transferred to the Weld Pit, canister leak check performed, gas sample taken from the canister, and a second canister leak check performed. Canister transferred to the silo.

$07 / 14 / 82$

Silo moved back to the storage pad.

$09 / 22 / 82$

Silo inst rumentation disconnected.

$09 / 23 / 82$

Silo returned to Hot Bay, fuel assembly transferred to lag storage location \#22, silo returned empty to storage pad.

FISCAL YEAR 1983

$10 / 05 / 82$

Canister in lag storage location 22 instrumented to monitor temperature.

$10 / 08 / 82$

Transferred canister from lag storage location 22 to the Weld Pit. Transferred the canister to lag storage location 11. Placed a TLD array over lag storage location 11. Raised the callister out of lag storage location 11 into the array of TLDs for 2 hours. Lowered the canister back into lag storage location 11 .

$10 / 13 / 82$

Transferred the canister from lag storage location 11 to the Weld Pit. Removed the shield plug. Performed a helium leak check of the canister. Obtained gas and full volume filtration samples of the canister atmosphere. The shield plug was installed. The canister was transferred to the canister cutter.

$10 / 14 / 82$

Initiated cutting of the canister. After about 90 degrees of cutter travel, the blade jammed. The cut continued, but the blade continued to loose cutter teeth. At about 240 degrees around the canister, the blade broke. The blade was replaced, but it also broke. A third blade was installed and the cut was completed. 
FUEL ASSEMBLY B02

DATE

$10 / 15 / 82$

The fuel assembly was engaged with the PWR fuel handling tool and removed from the cut canister. The 4 sides of the fuel were videotaped. The fuel was visually examined and photographed $(B \& W)$ at window $E-2$. The fuel assembly was transferred to the Survey Pit where surface contamination swipes were taken from designated fuel rod surfaces. Fuel rod temperatures were measured with a special probe. The fuel was taken back to window E- 2 for rephotography of the swiped areas. The fuel was then placed into a canister in the Weld Pit and a temporary canister lid installed. A drywell shield plug was installed and the canister was transferred to lag storage location 22 .

$10 / 18 / 82$

The canister in lag storage location instrumented to monitor temperature.

$01 / 20 / 83$

The canister was transferred from lag storage location 22 to the Weld Pit. The shield plug and temporary canister lid were removed. The fuel assembly was grappled with the PWR fuel handling tool and removed from the canister. The fuel was transferred to window E-2 for color photography. The fuel was returned to the canister in the Weld P1t and the temporary canister lid was installed.

$01 / 21 / 83$

The temporary canister lid was removed and the fuel assembly grappled using the PWR fuel handling tool. The fuel was transferred to window $\mathrm{E}-2$ for completion of color photography. The fuel was transferred to the Survey Pit where swipes were taken on designated fuel rod surfaces. The fuel was then transferred back to window E-2 for post-swipe photography. The fuel was placed back into the canister in the Weld Pit. The temporary canister lid and shield plug were installed. The canister was transferred to lag storage location 22. The canister was not reinstrumented.

$02 / 07 / 83$

The canister was transferred from lag storage location 22 to the canister cutter. The shield plug and temporary canister lid were removed. The upper nozzle access plug was removed. An attempt to engage fuel rods $G 9$ and J8 was made using the fuel rod handling tool, but the rods could not be engaged. A temporary canister lid was installed on the canister.

$02 / 08 / 83$

Removed the canister lid and gaged fuel rods $G 9$ and J8 with a special Go-No-Go gage to determine the diameters of the rods ( 0.428 inches).

Installed the temporary lid back on the canister. 
FUEL ASSEMBLY B02

DATE

$02 / 11 / 83$

Removed the canister 11d. Engaged rod 69 with the reworked fuel rod handling tool and pulled the rod from the fuel assembly. Transported the fuel rod to the Weld Pit and inserted the rod into a fuel rod storage container inside a $14 \mathrm{inch}$ BWR canister. Engaged rod J8 with the reworked fuel rod handing tool and pulled the rod from the fuel assembly. Transported the fuel rod to the Weld Pit and inserted the rod into the other fuel rod storage container inside the BWR canister. Installed the temporary lid and shield plug on the canister containing the fuel assembly. Transferred the canister containing the fuel assembly from the canister cutter to lag storage location 22.

$02 / 14 / 83$

The fuel rod storage container assembly was raised from the BWR canister. Both storage containers were plugged and the assembly lowered back into the canister. Installed the temporary $11 d$ and shield plug on the canister containing the fuel rods. Transferred the canister containing the fuel rods from the Weld Pit to lag storage location 20.

$02 / 16 / 83$

The canister was transferred from lag storage location 22 to the Weld Pit. The shield plug and temporary canister lid were removed. The upper nozzle access plug was reinstalled. The fuel assembly was grappled with the PWR fuel handling tool and removed from the canister. The fuel was transferred to the FTT canister. The FTT lid was installed on the FTT canister, but full installation could not be achieved due to an interference with and damage to the FTT gasket.

$02 / 17 / 83$

The FTT lid was raised and the gasket cut and retrleved for inspection. The FTT lid was lowered onto the FTT canister to verify that the re was no interference with the fuel assembly. The FTT lid was removed. The fuel assembly was engaged using the PWR fuel handling tool, removed from the FTT canister, and transported to the canister in the Weld Pit. A temporary lid and a shield plug were installed on the canister. The canister was transported to lag storage location 22 .

$02 / 18 / 83$

Canister transferred from lag storage location 22 to the Weld Pit. The shield plug was removed.

$02 / 22 / 83$

The temporary canister 1 id was removed. The fuel assembly was engaged with the. PWR fuel handling tool and transferred to the FTT canister. The FTT lid was installed. The FTT system was transported to the West Process Ce11. The FTT vent hose was connected to the FTT atmosphere control system and a vacuum pulled on the FTT system. A substantial leak was observed. 
FUEL ASSEMBLY B02

DATE

$02 / 23 / 83$

The FTT system was checked for leaks in the West Process Cell.

$02 / 24 / 83$

The FTT system was returned to the Hot Bay, checked for leaks, and vacuum checked after further torquing the lid nuts.

$02 / 25 / 83$

The FTT 11d was removed and the old gasket taken out of the FTT canfster. The FTT canister was placed on the Floor Mounted Handling System and moved into the Hot Hold Transfer Tunnel.

$02 / 26 / 83$

After FTT vent hose rework, the FTT system was brought back into the Hot Bay using the floor mounted handling system. A new gasket was placed in the FTT canister. The FTT lid was installed and a vacuum check performed on the canister. The $11 \mathrm{~d}$ bolts were tightened and additional $1 / 8$ turn beyond the specifled torque and a second vacuum check performed. The FTT system was then transported to the West Process Cell.

$02 / 28 / 83$

The FTT system was evacuated and backfflled with afr. Gas sampling was initiated, but a leak in the sampling system was observed.

$03 / 01 / 83$

Activated power to the FTT system. Applied power to the controllers to initiate the criteria for month 1 of test operation.

$03 / 111 / 83$

Gas samples were taken from the FTT system and the system was vented to atmosphere. System pressure was 0.1 torr.

$03 / 10 / 83$

Criteria for the first month of test operation was met, the test was initiated.

$04 / 08 / 83$

Completed operation of the FTT for the first month of operation. Initiated change to the temperature profile for the second month of operation.

$04 / 08 / 83$

Gas samples were taken from the FTT system. System pressure after sampling was -116.5 torr. A full volume filtration of the accumulator was performed.

$04 / 12 / 83$

Criteria for the second month of test operation was met. Proceeded with the test. 
FUEL ASSEMBLY B02

DATE

$05 / 05 / 83$

The canister containing fuel rods $G 9$ and $J 8$ was transferred from lag storage location 22 to the weld pit. The shield plug and temporary canister lid were removed. The storage container was raised from the canister using the BWR fuel handling tool. The tubes were backfilled with helium, the valves were closed, and the tubes were plugged. The temporary canister lid and the shield plug were installed. The canister was transferred to lag storage location 22 .

$05 / 11 / 83$

Completed operation of the FTT for the second month of operation. Initiated change to the temperature profile for the third month of operation.

$05 / 12 / 83$

Gas samples were taken from the FTT system. System pressure after sampling was -12.0 torr. A full volume filtration of the accumulator was performed.

$05 / 13 / 83$

Criteria for the third month of test operation was met. Proceeded with the test.

$06 / 03 / 83$

Gas samples were taken from the FTT system. System pressure after sampling was -108.9 torr. A full volume filtration of the accumulator was performed.

$06 / 13 / 83$

Completed operation of the FTT for the third month of operation. Initiated change to the temperature profile for the fourth month of operation.

$06 / 15 / 83$

Criteria for the fourth month of test operation was met. Proceeded with the test.

$07 / 11 / 83$

The canister containing fuel rods $G 9$ and $J 8$ was transferred from 1 ag storage location 22 to the weld Pit. The shield plug and temporary canister lid were removed. The storage container was raised from the canister using the BWR fuel handling tool. The storage containers were unplugged and the valves opened. A bar was placed under the support plate to hold the contalners up and the BWR fuel handling tool was disengaged. Fuel rod G9 was engaged using the fuel rod handling tool and removed from the storage container. The rod was marked on its lower end to identify orientation and transported to window E- 2 for partial visual examination and photography. The fuel rod was reinserted into its storage container and the fuel rod handling tool disengaged. 
FUEL ASSEMBLY B02

DATE

$07 / 12 / 83$

Fuel rod $G 9$ was engaged using the fuel rod handling tool and removed from the storage container. The fuel rod was transported to window $E-2$ for completion of visual examination and photography. The rod was transported to the Weld pit for collection of surface contamination swipes from designated rod surfaces. The fuel rod was reinserted into its storage container and the fuel rod handling tool disengaged.

$07 / 13 / 83$

Fuel rod G9 was engaged using the fuel rod handling tool and removed from the storage container. The fuel rod was transported to window E- 2 for post swipe visual examination and photography. The rod was transported to the Weld and reinserted into its storage container and the fuel rod handling tool disengaged. Fuel rod J8 was engaged using the fuel rod handiing tool and removed from the storage container. The rod was marked on its lower end to identify orientation and transported to window E-2 for partial visual examination and photography. The fuel rod was reinserted into its storage container and the fuel rod handling tool disengaged.

$07 / 14 / 83$

Fuel rod J8 was engaged using the fuel rod handling tool and removed from the storage container. The fuel rod was transported to window $\mathrm{E}-2$ for completion of visual examination and photography. The rod was transported to the Weld pit for collection of surface contamination swipes from designated rod surfaces. The fuel rod was transported to window $E-2$ for post swipe visual examination and photography. The rod was transported to the Weld and reinserted into its storage container and the fuel rod handling tool disengaged. The storage container was raised using the BWR fuel handling tool and the support bar removed. The tubes were backfllled with helium, the valves were closed, and the tubes were plugged. The temporary canister lid and the shield plug were installed. The canister was transferred to 1 ag storage location 22.

$07 / 14 / 83$

Completed operation of the FTT for the fourth month of operation. Initiated change to the temperature profile for the fifth month of operation.

$07 / 16 / 83$

Criterla for the fifth month of test operation was met. Proceeded with the test.

$07 / 18 / 83$

Gas samples were taken from the FTT system. System pressure after sampling was -196.8 torr. A full volume filtration of the accumulator was performed. 
FUEL ASSEMBLY B02

DATE

$08 / 09 / 83$

A facility power transient shut the FTT system down at about $1600 \mathrm{hrs}$. The system was restarted without interruption of the test.

$08 / 15 / 83$

Completed operation of the FTT for the fifth month of operation. Initiated change to the temperature profile for the sixth month of operation.

$08 / 16 / 83$

Criteria for the sixth month of test operation was met. Proceeded with the test.

$08 / 17 / 83$

Gas samples were taken from the FTT system. System was then vented to atmosphere. System pressure after venting was 0.1 torr. A full volume filtration of the accumulator was performed.

$08 / 21 / 83$

A facility power outage at 2022 hrs shut the FTT system down.

$08 / 22 / 83$

Reinitiated the test, starting with the seventh day of month 6 .

$09 / 14 / 83$

Completed operation of the FTT for the sixth month of operation. Initiated change to the temperature profile for the seventh month of operation.

$09 / 15 / 83$

Criteria for the seventh month of operation met. Proceeded with the test.

$09 / 20 / 83$

Gas samples were taken from the FTT system. System was then vented to atmosphere. System pressure after venting was 0.7 torr. A full volume filtration of the accumulator was performed.

FISCAL YEAR 1984

$10 / 01 / 83$

Seventh month of operation of the FTT in process.

$10 / 14 / 83$

Completed operation of the FTT for the seventh month of operation. Initiated the change to the temperature profile for the eighth month of operation.

$10 / 17 / 83$

Criteria for the eighth month of operation met. Proceeded with test. 
FUEL ASSEMBLY B02

DATE

$10 / 18 / 83$

Gas samples taken from the FTT system. The system pressure after sampling was 0.1 torr (system vented to atmosphere.) Full volume filtration of sampling accumulator performed.

$11 / 11 / 83$

Completed operation of the FTT for the eighth month of operation. Initiated the change to the temperature profile for the ninth month of operation.

$11 / 11 / 83$

Gas samples taken from the FTT system. The system pressure after sampling was 0.7 torr (system vented to atmosphere.) Full volume filtration of sampling accumulator performed.

$11 / 15 / 83$

Criteria for the ninth month of operation met. Proceeded with test.

$12 / 09 / 83$

Gas samples taken from the FTT system. The system pressure after sampling was 0.3 torr (system vented to atmosphere.) Full volume filtration of sampling accumulator performed.

$12 / 14 / 83$

Completed operation of the FTT for the ninth month of operation. Initiated the change to the temperature profile for the tenth month of operation.

$12 / 19 / 83$

Criteria for the tenth month of operation met. Proceeded with test.

$1 / 16 / 84$

Gas samples taken from the FTT system. The system pressure after sampling was 0.1 torr (system vented to atmosphere.) Full volume filtration of sampling accumulator performed.

$1 / 17 / 84$

Completed operation of the FTT for the tenth month of operation. Initiated the change to the temperature profile for the eleventh month of operation.

$1 / 18 / 84$

Criteria for the eleventh month of operation met. Proceeded with test.

$2 / 16 / 84$

Completed operation of the FTT for the eleventh month of operation.

$2 / 17 / 84$

Power shut off to the FTT system for wiring changes. 
FUEL ASSEMBLY B02

DATE

$2 / 17 / 84$

Gas samples taken from the FTT system. The system pressure after sampling was 0.2 torr (system vented to atmosphere.) Full volume filtration of sampling accumulator performed.

$2 / 24 / 84$

Power restored to the FTT system after wiring system changes. Initiated the change to the temperature profile for the twelfth month of operation.

$2 / 28 / 84$

Criteria for the twelfth month of operation met. Proceeded with test.

$3 / 22 / 84$

Gas samples taken from the FTT system. The system pressure after sampling was 36.6 torr (system not vented to atmosphere.) Full volume filtration of sampling accumulator performed.

\section{$3 / 28 / 84$}

Completed operation of the FTT for the twelfth month of operation. Intiated the change to the temperature proflle for the thirteenth month of operation.

$3 / 30 / 84$

Criteria for the thirteenth month of operation met. Proceeded with test.

$4 / 26 / 84$

Gas samples taken from the FTT system. The system pressure after sampling was 0.0 torr (system vented to atmosphere.) Full volume filtration of samiling accumulator performed.

$4 / 30 / 84$

Completed operation of the FTT for the thirteenth month of operation. Initiated the change to the temperature proifile for the fourteenth month of operation.

$5 / 1 / 84$

Criteria for the Eourteenth month of operation met. Proceeded with test.

$6 / 26 / 84$

Gas samples taken from the FTT system, including 2 special 1 gallon samples for LLNL. The system evacuated through a special LLNL charcoal canister and a 0.45 micron filter to -668 torr.

$6 / 27 / 84$

Completed operation of the FTT for the fourteenth month of operation. Initiated the cinange to the temperature profile for the fifteenth month of operation. 
FUEL ASSEMBLY BO2

DATE

$6 / 27 / 84$

Evacuated the FTT to -669 torr. Vented to atmosphere. Gas samples taken from the FTT System pressure after sampling was -95 torr. Full volume filtration of sampling accumulator performed.

$6 / 28 / 84$

Criteria for the fifteenth month of operation met. Proceeded with test.

$7 / 5 / 84$

Completed operation of the FTT for the fifteenth month of operation. Shut the FTT system down for a planned facility power outage scheduled for July 7 .

$7 / 6 / 84$

Gas samples taken from the FTT system. The system was evacuated through a 0.45 micron filter. System vented to atmosphere. Gas samples taken after venting, leaving the system pressure at -94.6 torr. Full volume filtration of sampling accumulator performed.

$7 / 9 / 84$

Initiated heatup to meet the temperature profile for month 16 operation of the FTT.

$7 / 13 / 84$

Criteria for month 16 met. Maximum fuel temperature of $233.5^{\circ} \mathrm{C}$.

$7 / 22 / 84$

Facility power outage at 1452 hrs shut down the FTT system.

$7 / 23 / 84$

FTT system restarted. Temperature profile still out.

$7 / 24 / 84$

Temperature profile for month 16 met again, test continued.

$7 / 31 / 84$

Facility power outage at 0300 hrs. shut down the FTT system. FTT restarted. Temperature not within required profile.

$8 / 1 / 84$

Facility power outage at $1700 \mathrm{hrs}$ shut down the FTT system. FTT restarted. Temperature not within required profile.

$8 / 2 / 84$

FTT profile criteria met. Test continued in month 16. 
FUEL ASSEMBLY B02

DATE

$8 / 14 / 84$

Completed operation of the FTT for the sixteenth month of operation. Initiated the change to the temperature profile for the seventeenth month of operation.

$8 / 14 / 84$

Gas samples taken from the FTT system. The system was evacuated through a 0.45 micron filter to -672 torr. System vented to atmosphere.

$8 / 15 / 84$

Gas samples taken after venting, leaving the system pressure at -99.2 torr. Full volume filtration of sampling accumulator performed.

$8 / 16 / 84$

Month 17 temperature profile met. Maximum fuel temperature $232^{\circ} \mathrm{C}$.

$9 / 17 / 84$

Completed operation of the FTT for the seventeenth month of operation. Intilated the change to the temperature profile for the elghteenth month of operation.

$9 / 18 / 84$

Gas samples taken from the FTT system. The system was evacuated through a 0.45 micron filter. System vented to atmosphere. Gas samples taken after venting, leaving the system pressure at -95 torr. Full volume filtration of sampling accumulator performed.

$9 / 19 / 84$

Month 18 temperature profile met. Maximum fuel temperature $230.5^{\circ} \mathrm{C}$. Test continued.

$9 / 19 / 84$

FTT shut down by a power outage at $2130 \mathrm{hrs}$.

$9 / 20 / 84$

FTT restarted, operation continued.

FISCAL YEAR 1985

$10 / 01 / 84$

Continued operation of the Metal Cask Simulation Test using the FTT. Month 18 in process. The maximum fuel temperature was $230.5^{\circ} \mathrm{C}$.

$10 / 10 / 84$

Planned facility power outage from 1505 hrs to 1517 hrs. No interruption of test temperature profile.

$10 / 17 / 84$

Power outage at $0300 \mathrm{hrs}$. shut down the FTT. Power restored at $0800 \mathrm{hrs}$.

$$
\text { A. } 12
$$


FUEL ASSEMBLY B02

DATE

$10 / 22 / 84$

Gas samples taken from the FTT system. System evacuated through 0.45 micron filter and then vented to atmosphere. Gas samples after the exchange taken.

$10 / 23 / 84$

Month 18 of Metal Cask Simulation Test completed. Inttlated temperature profile for month 19.

$10 / 24 / 84$

Criteria for month 19 met. The maximum fuel temperature was $229^{\circ} \mathrm{C}$. Test continued.

$12 / 03 / 84$

Gas samples taken from the FTT system. System evacuated through 0.45 micron filter and then vented to atmosphere. Gas samples after the exchange taken.

$12 / 03 / 84$

Month 19 of Metal Cask Simulation Test completed. System shut down to change over to the digital temperature controller system. The system restarted with the digital temperature control system.

$12 / 06 / 84$

Inftiated temperature proftle for month 20 .

$12 / 08 / 84$

Criteria for month 20 met. The maximum fuel temperature was $227.5^{\circ} \mathrm{C}$. Test continued.

$1 / 3 / 85$

Gas samples taken from the FTT system. System evacuated through 0.45

micron filter and then vented to atmosphere. Gas samples after the exchange taken.

$1 / 3 / 85$

Month 20 of the Metal Cask Simulation Test completed. Initiated temperature profile for month 21 .

$1 / 4 / 85$

Criterla for month 21 met. The maximum fuel temperature was $226^{\circ} \mathrm{C}$. Test continued.

$1 / 25 / 85$

Gas samples taken from the FTT system. System evacuated through 0.45

micron filter and then vented to atmosphere. System evacuated to -120

torr. Gas samples then taken, reducing the system pressure to -195 torr. 
FUEL ASSEMBLY B02

DATE

$1 / 25 / 85$

Month 21 of the Metal Cask Simulation Test completed. Initiated temperature profile for month 22 .

$1 / 26 / 85$

Criteria for month 22 met. The maximum fuel temperature was $224.5^{\circ} \mathrm{C}$. Test continued.

$1 / 31 / 85$

Gas samples taken from the FTT system. System evacuated to -300 torr.

$2 / 4 / 85$

Gas samples taken from the FTT system. System evacuated to -400 torr.

$2 / 8 / 85$

Month 22 of the Metal Cask Simulation Test completed. Initiated temperature profile for month 23.

$2 / 8 / 85$

Gas samples taken from the FTT system. System evacuated through 0.45

micron filter and then vented to atmosphere. System evacuated to -120

torr. Gas samples then taken, reducing the system pressure to -195 torr.

$2 / 10 / 85$

Criteria for month 23 met. The maximum fuel temperature was $223.5^{\circ} \mathrm{C}$.

Test continued.

$2 / 14 / 85$

Gas samples taken from the FTT system. System evacuated to - 300 torr.

$2 / 18 / 85$

Gas samples taken from the FTT system. System evacuated to -400 torr.

$2 / 22 / 85$

Month 23 of the Metal Cask Simulation Test completed. Initiated temperature profile for month 24.

$2 / 22 / 85$

Gas samples taken from the FTT system. System evacuated through 0.45 micron filter and then vented to atmosphere. Gas samples then taken.

$2 / 23 / 85$

A facility power transient shut down the temperature controller computer which cut off power to the heaters.

$2 / 26 / 85$

Criteria for month 24 met. The maximum fuel temperature was $222.5^{\circ} \mathrm{C}$.

Test continued. 
FUEL ASSEMBLY B02

DATE

$3 / 11 / 85$

Criteria for month 24 completed. All controllers reset to 0 to initiate post-test calibration run.

$3 / 11 / 85$

Gas samples taken from the FTT system. System evacuated through 0.45

micron filter and then vented to atmosphere. Gas samples then taken.

$3 / 12 / 85$

System pressure at -176.3 . Vented FTT system to atmosphere.

$3 / 13 / 85$

System pressure at -24.2 . Vented FTT system to atmosphere.

$3 / 26 / 85$

Thermal stabilization of the fuel assembly in the FTT reached, completing the calibration run. The maximum fuel temperature was measured at $125.8^{\circ} \mathrm{C}$.

FTT temperature control system deactivated.

$5 / 2 / 85$

Disconnected the FTT heater, thermocouple and ACS leads.

$5 / 3 / 85$

Disconnected the FTT stand from the seismic restraint fixture. Moved the FTT stand to directly under the West Process Cell access plug. Removed the roof access plug and transferred the stand to the Hot Bay, placing the stand in the calorimeter pit. Upon initial steps to remove the lid, the North WMHS failed. The FTT stand was returned to the West Process Celi and the roof access plug reinstalled.

$5 / 8 / 85$

Removed the access plug from the roof of the West Process Ce11 in preparation for removing the FTT stand.

$5 / 9 / 85$

Transferred the FTT stand to the Hot Bay, placing the stand in the calorimeter pit. Removed the FTT canister 11d, placing it in the designated holding canister. Fuel assembly grappled using the calorimeter grapple. Fuel assembly withdrawn, videotaping the 0 face of the fuel assembly. Swipe samples taken from the 4 sides of lower nozzle. The fuel assembly was then transferred to the weld pit and placed into a temporary storage canister. Swipe samples taken on the exterior of the canister which would be covered by the shield plug. Installed a temporary canister lid on the canister.

$5 / 10 / 85$

Installed the shield plug on the canister. Transferred the canister to the survey pit and took swipe samples of the canister exterior to check for surface contamination. Transferred the canister to the lag storage pit and placed the canister into location 5. 
FUEL ASSEMBLY BO2

DATE

$6 / 17 / 85$

Transferred the cantster from lag storage location 5 to the Weld Pit. Removed the shield plug and temporary canister 11d. Engaged the fuel assembly with the calorimeter grapple and videotaped the 4 sides of the fuel assembly. Transported the assembly to the inspection station at window E-2. Obtained photomosalcs of the 4 sides of the assembly and photographs of areas to be swiped. Placed the fuel assembly in the temporary storage canister in the Weld Pit and installed a temporary canister 11d.

$6 / 18 / 85$

Removed the temporary cansister 11d. Engaged the fuel assembly with the calorimeter grapple and transported the assembly to the Survey Pit. Obtained contamination characterization, integrity monitoring, and post. test comparison swipes. Transferred the assembly to the inspection station at window E-2 and rephotographed the swipe areas. Performed a visual inspection of the assembly to compare pre- and post-test condition of the fuel. Transferred the assembly to the Weld Pit and placed the fuel assembly in the temporary storage canister. Installed a temporary canister 1id.

$6 / 19 / 85$

Removed the temporary canister lid. Engaged the fuel assembly with the calorimeter grappie and transported the assembly to the inspection station at window E-2. Representatives from PNL performed a visual inspection of the assembly. Returned the fuel assembly in the temporary storage canister In the Weld Pit. Installed a temporary canister 11d.

$6 / 20 / 85$

Installed a shield plug on the canister. Transferred the canister to lag storage location 5 .

$7 / 15 / 85$

Transferred the canister from lag storage location 5 to the Weld Pit. Removed the shield plug and temporary canister 1id. Fuel assembly engaged using the calorimeter grapple and transferred the fuel assembly to the widow E-5 inspection location. Rephotographed designated fuel rod areas. The fuel assembly was transferred back to the canister in the Weld P1t. The temporary canister $11 \mathrm{~d}$ and shield plug were reinstalled and the canister transferred back to lag storage location 5 .

$9 / 25 / 85$

Transferred the canister contalning fuel rods $G 9$ and J8 from lag storage location 20 to the Weld Pit. Removed the shield plug and canister lid. Installed the canister handling fixture. Opened the 2 fuel rod storage contalners. Transferred the canister to the canister cutter. Transferred the canister containing the fuel assembly from lag storage location 5 to the Weld Pit. Removed the shield plug and temporary canister lid. Attempted to remove the access plug from the upper nozzle of the fuel assembly but 2 of the 3 tabs would not rotate. Reinstalled the temporary canister 11d. 
FUEL ASSEMBLY B02

DATE

$9 / 26 / 85$

Removed the temporary canister 11d. Engaged the fuel assembly with the calorimeter grapple and raised the fuel assembly to inspect the lower end of the access plug and to attempt to rotate the locking cams. Fue 1 assembly lowered 1nto the canister. Other unsuccessful attempts made to remove the access plug. The temporary canister lid reinstalled on the cantster.

$9 / 27 / 85$

Removed the temporary cansister 11d. Engaged the fuel assembly with the calorlmeter grapple and ralsed the upper portion of the fuel clear of the canister. Using a drift, the 2 stuck cams were knocked into position. The fuel assembly was then lowered into the canister and the grapple disengaged. The access plug was removed from the upper nozzle.

Removed fuel rod $G 9$ from the storage contalner and installed it into location $G 9$ of the fuel assembly. Removed fuel rod J8 from the storage contalner and 1nstalled 1t into location J8 of the fuel assembly. Installed the temporary canister $11 d$ and shield plug. Transferred the canister to lag storage location 5.

Fiscal Year 1986

$10 / 14 / 85$

Transferred the canister from lag storage location 5 to the weld pit. Removed the shield plug and temporary canister 1id. Installed the repalred access plug 1nto the fuel assembly upper nozzle. Installed the canister lid and shield plug. Transferred the canister back to lag storage location 5 .

$5 / 86$

Removed the fuel assembly from the canister, performed visual inspection, and loaded assembly in shipping cask for motor transportation to INEL. 
HANDLING HISTORY OF FUEL ASSEMBLY B03

Fuel Serial Number: B03

Date Irradiation Started: $01 / 12 / 72$

Date Irradiation Ended: 10/25/75

Burnup : $\quad 25,665$ MWD/MTU

Activities Prior to Receipt at E-MAD:

Precharacterization at BCL,

5 Fuel Rods Removed, Tested and Replaced

MIT Coupons Installed

Received at EMAD: $\quad 01 / 10 / 79$

By Shipping Cask: NAC-1

\section{DATE}

$01 / 10 / 79$

Shipping cask received, fuel assembly unloaded from shipping cask and placed in a canister in the Weld Pit and a lid Installed on the canister. Canister seal welded.

$01 / 11 / 79$

Canister backfilled with helium and leak checked, shield plug installed and canister placed in the Transfer Pit.

$01 / 12 / 79$

Transported to Drywe11 \#5 by the Emplacement/Installation Vehicle (EIV) for running of Phase I of the Isolated Drywell Test.

$01 / 13 / 79$

Intiated data collection for Phase I of the Isolated Drywell Test.

$06 / 30 / 80$

Phase I of the Isolated Drywell Test completed. Continued to collect data to monitor temperatures.

$08 / 04 / 80$

Moved to the Transfer P1t using the EIV. Transferred to the Weld PIt, canister leak check performed, gas sample taken from cantster, a second canister leak check performed, canister moved to Transfer Pit, then transported to Drywell \#3 using the EIV. 
FUEL ASSEMBLY B03

DATE

$08 / 05 / 80$

Drywe1l interaction test intiated.

$05 / 15 / 81$

Drywell interaction test completed. Monitoring of temperatures continued.

$06 / 23 / 82$

Moved to the Transfer P1t using the EIV. Transferred to the Weld Pit, canister leak check performed, gas sample taken from canister, a second canister leak check performed, and canister moved to Transfer Pit.

$06 / 24 / 82$

Transported to Drywell \#3 using the EIV.

FISCAL YEAR 1983

DATE

$08 / 12 / 83$

Retrieved the canister from drywell 3 using the Emplacement/Installation Vehicle and placed the canister in the Hot Bay Transfer Pit. Transferred the cantster to the Weld Pit and removed the shield plug. Performed a helium leak check on the canister and obtained a gas sample from the canister atmosphere. Performed a post-sampling canister leak check. Installed the shield plug and transferred the canister to the Transfer Pit.

$08 / 15 / 83$

Transferred the canister to drywe11 \#3 using the Emplacement/Installation vehicle.

FISCAL YEAR 1984

$12 / 20 / 83$

Canister transferred from drywell 3 to the Transfer Pit using the EIV shield. Locomotive L-5 used as prime mover. Canister transferred to the Weld Pit. The drywell shield plug was removed. A helium leak check was performed. Gas samples taken from the canister. A second helium leak check was performed. Drywell shield plug installed. Canister transferred to and placed in the Transfer Pit.

$12 / 21 / 83$

Canister transferred to drywell 3 using the EIV shield. Locomotive L- 5 used as prime mover. Drywell instrumentation installed and checked out. Thermal monitoring of canister, drywell liner, and surrounding soil initiated. 
FUEL ASSEMBLY B03

DATE

$6 / 5 / 84$

Canister transferred from drywel1 3 to Hot Bay Transfer Pit then to lag storage location 12. Canister transferred from lag storage location 12 to the weld pit. Shield plug removed. Canister leak check performed. Canister gas and full volume filtration samples collected. Shield plug installed on the canister but 1 support pin could not be fully threaded in place.

$6 / 6 / 84$

The shield plug was removed and replaced with a different plug, The support pins were threaded in place. Canister transferred to the canister cutter. Canister cut open without incident using the canister cutter. Fuel assembly removed from the cut canister using the calorimeter grapple. The 4 sides of the fuel assembly were videotaped. visual examination and photodocumentation of the fuel was performed at the E-2 window. Pre-swipe photos were taken. The fuel assembly was placed in a canister at the Weld Pit. The MIT pressure plugs were loosened. The plug at location $\mathrm{K} 11$ was removed. The plug in location E5 could not be removed. A temporary canister lid was installed.

$6 / 7 / 84$

The temporary canister lid was removed. The fuel assembly was engaged with the calorimeter grapple and removed from the canister. The fuel assembly was transferred to the survey pit. Integrity monitoring and surface contamination characterizaton swipes were taken. Post-swipe photos were taken at the E-2 window. The fuel was returned to the canister in the weld Pit. The remaining pressure plug was removed. The 2 MIT capsule assemblies were removed from their guide tube locations. The temporary lid and shield plug were installed on the canister. The canister was transferred to lag storage location 12.

FISCAL YEAR 1985

$12 / 10 / 84$

Transferred the canister from lag storage location 12 to the Weld Pit. Removed the shield plug and temporary canister lid. Fuel assembly engaged using the calorimeter grapple and transferred to the Survey Pit. The 16 integrity monitoring swipe samples taken. The fuel assembly was transferred back to the canister in the Weld Pit. The temporary canister lid and shield plug were reinstalled and the canister transferred back to lag storage location 12 .

$4 / 1 / 85$

Transferred the canister from lag storage location 12 to the Weld Pit. Removed the shield plug and temporary canister lid. Fuel assembly engaged using the calorimeter grapple and transferred to the Survey Pit. The 16 integrity monitoring swipe samples taken. The fuel assembly was transferred back to the canister in the Weld Pit. The temporary canister lid and shield plug were reinstalled and the canister transferred back to lag storage location 12. 
HANDLING HISTORY OF FUEL ASSEMBLY B41

Fuel Serial Number: B41

Date Irradiation Started: $\quad 01 / 12 / 72$

Date Irradiation Ended: 10/25/75

Burnup: $\quad 25,665$ MWD/MTU

Activities Prior to Recelpt at E-MAD:

Precharacterization at BCL,

5 Fuel Rods Removed, Tested and Replaced

Recelved at E-MAD:

$01 / 23 / 79$

By Sh1pping Cask: NAC-1

DATE

$01 / 23 / 79$

Sh1pping cask recelved, fuel assembly unloaded and placed in a cantster in the Weld P1t and a canister lid installed. Canister seal welded, backfilled with helium and leak checked. Shleld plug installed and canister placed in the Transfer P1t.

$01 / 24 / 79$

Transported to Drywell \#3 by the EIV for running of Phase I of the Isolated Drywell Test.

$01 / 25 / 79$

Test Inftiated.

$06 / 30 / 80$

Phase I of the Isolated Drywe11 Test completed. Cont1nued to collect data to monttor temperatures in the drywell.

$08 / 04 / 80$

Moved to Drywell \#2 using the EIV.

$08 / 05 / 80$

Moved to the Transfer Pit using the EIV. Transferred to the Weld PIt, cantster leak check performed, gas sample taken from cantster, a second canister leak check performed, canister moved to Transfer P1t, and then moved to Drywell \#2 using the EIV.

$08 / 06 / 80$

Drywell interaction test Inftiated.

$05 / 15 / 81$

Drywell interaction test completed. Data collection continued to monitor temperature conditions in the drywell. 
FUEL ASSEMBLY B4 1

DATE

$06 / 21 / 82$

Moved to the Transfer Pit using the EIV. Transferred to the Weld Pit, canister leak check performed, gas sample taken from canister, a second canister leak check performed, and canister moved to Transfer Pit.

$06 / 22 / 82$

Moved to Drywe11 \#2 using the EIV.

FISCAL YEAR 1983

$08 / 11 / 83$

Retrieved the canister from drywe11 \#2 using the Emplacement/Installation Vehicle and placed the canister in the Hot Bay Transfer Pit. Transferred the canister to the Weld Pit and removed the shield plug. Performed a helium leak check on the canister and obtained a gas sample from the canister atmosphere. Performed a post-sampling canister leak check. Installed the shield plug and transferred the canister to the Transfer Pit.

$08 / 12 / 83$

Transferred the canister to drywell $\# 2$ using the Emplacement/Installation vehicle.

FISCAL YEAR 1984

$12 / 19 / 83$

The canister was transferred from drywell 2 to the transfer pit using the EIV shield. The canister was transferred to the Weld Pit and the shield plug removed. A helium leak check was performed on the canister. Gas samples were taken from the canister atmosphere. A second leak check was performed. The shield plug was installed and the canister was transferred to the Transfer Pit.

$12 / 20 / 83$

The canister was transferred to drywell 2 using the EIV shield. Drywell instrumentation was installed and thermal monitoring of canister, drywe 11 liner, and surrounding soil continued.

$7 / 24 / 84$

The canister was transferred from drywe 112 to the transfer pit using the EIV shield. The canister was transferred to the Weld Pit and the shield plug removed. A helium leak check was performed on the canister. Gas samples were taken from the canister atmosphere. A second leak check was performed. The shield plug was installed and the canister was transferred to the Transfer Pit. The canister was transferred to drywel1 2 using the EIV shield. Drywell instrumentation was installed and thermal monitoring of canister, drywell liner, and surrounding soil continued. 
FISCAL YEAR 1985

FUEL ASSEMBLY B41

DATE

$10 / 24 / 84$

Canister transferred from drywel1 2 to the Transfer Pit and on to LSP 8 .

$11 / 19 / 84$

Transferred the canister from lag storage location 8 to the Weld Pit. Removed the shield plug and performed a helium leak check. Installed the gas sampling plenum and took gas samples of the canister atmosphere. Evacuated the canister atmosphere through a 0.45 micron filter and backfilled the canister with helium to 4.0 psi ( 920 torr). Installed shield plug and transferred the canister back to lag storage location 8 . Prepared the gas sampling system for additional sampling. Transferred the canister back to the Weld Pit and removed the shield plug. Obtained gas samples from the canister.

\section{$11 / 20 / 84$}

Performed a helium leak check on the canister. Installed the shield plug and transferred the canister back to lag storage location 8. Instrumented the canister to measure external canister temperature.

\section{$12 / 20 / 84$}

Transferred the canister from lag storage changed location 8 to the Weld Pit. Removed the shield plug and performed a helium leak check. Installed the gas sampling plenum and took gas samples of the canister atmosphere. Performed a helium leak check on the canister. Installed the shield plug and transferred the canister back to lag storage location 8 .

\section{$1 / 16 / 85$}

Transferred the canister from lag storage location 8 to the Weld Pit. Removed the shield plug and performed a helium leak check. Installed the gas sampling plenum and took gas samples of the canister atmosphere. Performed a helium leak check on the canister. Installed the shield plug and transferred the canister back to lag storage location 8 .

\section{$2 / 20 / 85$}

Transferred the canister from lag storage location 8 to the Weld Pit. Removed the shield plug and performed a hellum leak check. Installed the gas sampling plenum and took gas samples of the canister atmosphere. Performed a helium leak check on the canister. Installed the shield plug and transferred the canister back to lag storage location 8 .

\section{$6 / 20 / 85$}

Transferred the canister from lag storage location 8 to the Weld Pit. Removed the shield plug and performed a helium leak check. Installed the gas sampling plenum and took gas samples of the canister atmosphere. 
FUEL ASSEMBLY B41

DATE

$6 / 21 / 85$

Performed a helium leak check on the canister. Installed the shield plug

and transferred the canister back to lag storage location 8.

$8 / 8 / 85$

Removed the thermocouples monitoring canister temperature. Transferred the canister from lag storage location 8 to the Weld Pit. Removed the shield plug and performed a helium leak check. Installed the gas sampling plenum and took gas samples of the canister atmosphere. Performed a full volume filtration of the atmosphere of the canister through a 0.45 micron filter and then vented to atmosphere. Installed the shield plug. Transferred the canister to the Canister Cutter and initiated cutting. At about $2 / 3$ the way around the canister, the blade broke. The blade was replaced and the cut completed. Engaged the fuel assembly with the calorimeter grapple and videotaped the 4 sides of the fuel assembly. Returned the fuel assembly into the cut canister in the Canister Cutter. placed a temporary cover over the upper nozzle of the fuel assembly.

$8 / 9 / 85$

Removed the cover from over the fuel assembly. Engaged the fuel assembly with the calorimeter grapple and transported the assembly to the inspection station at window E-2. Obtained a photomosalc of the 0 degree face of the assembly. Performed a visual inspection of the assembly. Obtained photographs of the areas to be swiped. Transferred the assembly to the Survey Pit and obtained characterization and integrity monitoring swipes. Returned the assembly to the inspection station at window $E-2$ and rephotographed the swipe areas. Placed the fuel assembly in the temporary storage canister in the Weld Pit. Installed a temporary canister $11 d$ and shleld plug. Transferred the canister to lag storage location 8.

$9 / 5 / 85$

Instrumented the canister in the lag storage pit for monitoring of canister temperature.

$5 / 86$

Removed the fuel assembly from the canlster, performed visual inspection, and loaded assembly in shipping cask for motor transportation to INEL. 
Fuel Serial Number:

Date Irradiation Started:

Date Irradiation Ended:

Burnup :

Activities Prior to Recelpt at E-MAD:

Precharacterization at BCL,

5 Fuel Rods Removed, Tested and Replaced

Recelved at EMAD:

By Shipping Cask:

\section{B43}

$01 / 12 / 72$

$10 / 25 / 75$

25,595 MWD/MTU
NAC- 1

\section{DATE}

02/06/79

Shipping cask recelved, fuel assembly placed in a canister in the Weld Pit, a temporary lid installed on the canister, and the canister moved to the Transfer Pit.

$07 / 18 / 79$

Transferred the canister to the Weld Pit, removed temporary 11d, transferred the fuel as sembly to the Fuel Assembly Internal Temperature Measurement (FAITM) Test stand canister and placed the FAITM Test stand canister lid in place.

$07 / 19 / 79$

Sealed the FAITM Test stand canister, and transferred to the West Process Ce11.

$07 / 23 / 79$

Completed Test 1 - "Air Calibration"

$07 / 25 / 79$

Completed Test 2 - "Vacuum Calibration"

08/05/79

Completed Test 3 - "Hellum Calibration"

$09 / 05 / 79$

Completed Rerun Test 1 - "Air Calibration"

$09 / 07 / 79$

Completed Rerun Test 2 - "Vacuum Callbration" 
FUEL ASSEMBLY B43

DATE

$09 / 11 / 79$

Completed Rerun Test 3 - "Hellum Calibration"

$09 / 13 / 79$

Completed Test 4 - "Drywel1 Test Run - Hellum"

$09 / 14 / 79$

Test 5 - "Drywell Test Rerun - Vacuum" was aborted when heater stuck in closed position, vacuum was broken and power shutdown to FAITM Test temperature controllers.

$09 / 17 / 79$

Initiated Rerun Test 2 - "Vacuum Calibration"

$09 / 18 / 79$

Completed Rerun Test 2

$09 / 20 / 79$

Completed Rerun Test 1 - "Air Calibration"

$11 / 12 / 79$

Initiated Test 6 - "Drywe11 Test Run - Air"

$11 / 14 / 79$

Completed Test 6, evacuated FAITM Test stand, and filled with helium.

$11 / 27 / 79$

Completed Rerun Test 4 - "Drywe11 Test Run - Hellum"

$11 / 28 / 79$

Completed Rerun Test 5 - "Drywell Test Run - Vacuum"

$11 / 29 / 79$

Completed Test 8 - "Electrically Heated Drywell Test Run - Vacuum"

$11 / 30 / 79$

Completed Test 9 - "Electrically Heated Drywe11 Test Run - Hellum"

$12 / 06 / 79$

Completed Test 10 - "Uniform Canister Temperature-Helium C250 F"

$12 / 07 / 79$

Completed Test 11 - "Uniform Canister Temperature-Helium $C 300^{\circ} \mathrm{F} "$

$12 / 11 / 79$

Completed Test 12 - "Uniform Canister Temperature-Helium $9400^{\circ} \mathrm{F} "$

$12 / 17 / 79$

Completed Test 13 - "Uniform Canister Temperature-Helium C500"F" 
FUEL ASSEMBLY B43

DATE

$12 / 20 / 79$

Completed Test 14 - "Uniform Canister Temperature-Vacuum $9500^{\circ} \mathrm{F}$ "

$12 / 21 / 79$

Vacuum was broken and power shut down.

$01 / 02 / 80$

Initiated Test 18 - "Uniform Canister Temperature-Air $9250^{\circ} \mathrm{F}$ "

$01 / 04 / 80$

Completed Test 18.

$01 / 10 / 80$

Completed Test 7 - "Electrically Heated Drywe11 Test Run-Air"

$01 / 14 / 80$

Completed Test 19 - "Uniform Canister Temperature-Air @300F"

$01 / 17 / 80$

Completed Test 20 - "Uniform Canister Temperature-Air $0400^{\circ} \mathrm{F} "$

$01 / 24 / 80$

Completed Test 21 - "Uniform Canister Temperature-Air $0500^{\circ}$ F"

$01 / 30 / 80$

Completed Test 15 - "Uniform Canister Temperature-Vacuum Q400 F"

$02 / 08 / 80$

Completed Test 17 - "Uniform Canister Temperature-Vacuum $2250^{\circ} \mathrm{F}$ "

$02 / 11 / 80$

Completed Test 16 - "Uniform Canister Temperature-Vacuum @300 F"

$02 / 11 / 80$

Broke vacuum on Test stand.

$02 / 20 / 80$

Power shutdown to FAITM Test temperature controllers.

$05 / 30 / 80$

Initiate $500^{\circ} \mathrm{F}$ uniform canister profile for gas sampling.

$06 / 04 / 80$

FAITM Test stand canister profile stable, obtained gas samples, shut down power to the FAITM Test temperature controllers.

$06 / 18 / 80$

Completed Rerun Test 7 - "Electrically Heated Drywell Test Run-Air" 
FUEL ASSEMBLY B43

DATE

$06 / 25 / 80$

Completed Rerun Test 8 - "Electrically Heated Drywell Test Run-Vacuum"

$06 / 26 / 80$

Initiated rerun of Test 9 - "Electrically Heated Drywell Test Run Helium"

$07 / 01 / 80$

Aborted Test 9 due to excessive helium leaks in the system.

$09 / 08 / 80$

Moved the FAITM Test stand canister from the West Process Cell to the Hot Bay, performed a leak check on the FAITM Test stand canister.

$09 / 09 / 80$

Transferred the fuel assembly to a canister in the Weld Pit. Installed a screw-on lid and left the canister overnight in the Weld Pit for weld pit calorimetry.

$09 / 10 / 80$

Placed the fuel assembly in the calorimeter, ran calorimeter- $(0.637 \mathrm{~kW})$, placed the fuel into the canister in the Weld Pit, installed threaded 1id. Initiated welding. Welder malfunction. Left canister in the Weld Pit overnight for Weld Pit calorimetry.

$09 / 11 / 80$

Shield plug installed and canister transferred to the Transfer Pit.

$09 / 12 / 80$

Transferred the canister to the Weld Pit, removed shield plug, and rewelded the canister. Backfilled with helium and leak checked. Shield plug installed and canister transported to the Transfer Pit.

$09 / 15 / 80$

Canister transported to Drywell $\|_{1} 1$ by the EIV.

$09 / 16 / 80$

Initiated Drywell Interaction Test.

$05 / 15 / 81$

Drywell Interaction Test completed. Data collection continued to monitor temperatures in drywell.

$06 / 17 / 82$

Moved to the Hot Bay Transfer Pit by the EIV, installed in the Weld Pit, performed canister leak check.

$06 / 18 / 82$

Performed gas sampling and a second canister leak check. Moved to the Transfer Pit. Transported the canister to Drywell \#1 using the EIV. 
FUEL ASSEMBLY B43

FISCAL YEAR 1983

DATE

$08 / 09 / 83$

Retrieved the canister from drywe11 \#1 using the Emplacement/Installation Vehicle and placed the canister in the Hot Bay Transfer Pit. Transferred the canister to the Weld Pit and removed the shield plug. Performed a helium leak check on the canister.

$08 / 10 / 83$

Obtained a gas sample from the canister atmosphere. Performed a postsampling canister leak check. Installed the shield plug and transferred the canister to the Transfer Pit. Transferred the canister to drywell \#l using the Emplacement/Installation vehicle.

FISCAL YEAR 1984

$2 / 13 / 84$

The canister was transferred from drywell l to the Transfer Pit using the EIV shield. The canister was transferred to lag storage location 18 and then to the Weld Pit. The shield plug was removed.

$2 / 14 / 84$

A helium leak check was performed. Gas samples were taken from the canister atmosphere. A second leak check was performed. The shield plug was installed and the canister was transferred to the canister cutter.

\section{$2 / 15 / 84$}

The canister was cut open using the canister cutter. The fuel was engaged using the calorimeter grapple and removed from the cut canister. The $/$ sides of the fuel assembly were videotaped. The fuel assembly was then placed into an empty canister in the Weld Pit. A temporary canister lid and shield plug were installed and the canister was transferred to lag storage location 18.

$3 / 5 / 84$

Transferred the canister from lag storage location 18 to the Weld Pit. The shield plug and temporary canister lid were removed. The fuel assembly was engaged using the calorimeter grapple and removed from the canister. Visual examination and photodocumentation were performed at window E2. The fuel was returned to the canister and a temporary canister lid was installed. 
FUEL ASSEMBLY B43

DATE

$3 / 6 / 84$

The temporary canister lid was removed. The fuel assembly was engaged using the calorimeter grapple and removed from the canister. Transferred the fuel assembly to the Survey Pit and obtained integrity monitoring and contamination characterization swipes from designated fuel rod surfaces. Post-swipe photos were taken at window E-2. The fuel assembly was placed into the canister in the Weld Pit. A temporary canister lid was installed.

$3 / 7 / 84$

The temporary canister lid was removed. The fuel assembly was engaged using the calorimeter grapple and removed from the canister. The fuel assembly was placed into the calorimeter vesse1. An attempt was made to measure the decay heat rate of the fuel assembly, but stabilization of the system was not achieved. The fuel assembly was placed into the canister in the Weld Pit. A temporary canister lid was installed.

$3 / 8 / 84$

The temporary canister lid was removed. The fuel assembly was engaged using the calorimeter grapple and removed from the canister. The fuel assembly was placed into the calorimeter vessel. The decay heat rate of the fuel assembly was measured at $0.442 \mathrm{~kW}$ using boiling water calorimetry. The fuel assembly was placed into the canister in the weld Pit. A temporary canister lid was installed.

$3 / 9 / 84$

A shield plug were installed and the canister was transferred to lag storage location 18 .

$8 / 16 / 84$

Transferred the canister from lag storage location 18 to the Weld Pit.

The shield plug and temporary canister lid were removed. The fuel assembly was engaged using the calorimeter grapple and removed from the canister. Transferred the fuel assembly to the Survey Pit and obtained integrity monitoring swipes from designated fuel rod surfaces. The fuel assembly was placed into the canister in the Weld Pit. A temporary canister lid was installed. A shield plug was installed and the canister was transferred to lag storage location 18 .

FISCAL YEAR 1985

$12 / 17 / 84$

Transferred the canister from lag storage location 18 to the Weld Pit. Removed the shield plug and temporary canister lid. Fuel assembly engaged using the PWR Fuel Handling Tool and transferred to the Survey Pit. The 16 integrity monitoring swipe samples taken. The fuel assembly was transferred back to the canister in the Weld Pit. The temporary canister lid and shield plug were reinstalled and the canister transferred back to lag storage location 18. 
FUEL ASSEMBLY B43

DATE

$4 / 2 / 85$

Transferred the canister from lag storage location 18 to the Weld Pit.

Removed the shield plug and temporary canister lid. Fuel assembly engaged using the calorimeter grapple and transferred to the Survey Pit. The 16 integrity monitoring swipe samples taken. The fuel assembly was transferred back to the canister in the Weld Pit. The temporary canister lid and shield plug were reinstalled and the canister transferred back to lag storage location 18.

$8 / 22 / 85$

Transferred the canister from lag storage location 18 to the Weld Pit. Removed the shield plug and temporary canister lid. Fuel assembly engaged using the calorimeter grapple and transferred to the calorimeter. Inttiated thermal stabilization of the system.

$8 / 23 / 85$

The decay heat rate of the fuel assembly was measured at $0.392 \mathrm{~kW}$. The fuel was removed from the calorimeter and transferred to the canister in the Weld Pit. Installed a temporary canister lid and shield plug. Transferred the canister to lag storage location 18.

FISCAL YEAR 1986

$5 / 86$

Removed the fuel assembly from the canister, performed visual inspection, and loaded assembly in shipping cask for motor transportation to INEL. 
HANDLING HISTORY OF FUEL ASSEMBLY DOI

\author{
Fuel Serial Number: D01/LMO 140 \\ Date Irradiation Started: $\quad 12 / 12 / 74$ \\ Date Irradiation Ended: $\quad 11 / 19 / 77$ \\ Burnup: $\quad 28,430 \mathrm{MWD} / \mathrm{MTU}$ \\ Activities Prior to Recelpt at E-MAD:
}

Precharacterization at BCL,

20 Fuel Rods Removed. 5 Fuel Rods Tested.

16 Fuel Rods and 4 Dummy Steel Rods

Reinstaller

MIT Coupons Installed

Received at EMAD: $12 / 12 / 79$

By Shipping Cask: NLI $1 / 2$

DATE

$12 / 12 / 79$

Shipping cask received, fuel assembly transferred to a canister in the weld pit, and a lid Installed. Canister seal welded. Canister backfilled with helium and leak checked. Canister transferred to lag storage location \#2l.

$01 / 23 / 80$

Transferred to Weld Pit, checked canister thermocouple channel locations, returned to lag storage location \#21.

$02 / 14 / 80$

Moved to the Weld Pit, switched to Climax shield plug, checked alignment of canister thermocouple channels using wire, reinstalled lag storage shield plug, and returned to lag storage location \#21.

$05 / 14 / 80$

Moved to Weld Pit, switched to Climax shield plug and loaded into Surface Transport Vehicle.

$05 / 15 / 80$

Released for transport to Climax. Transported to Climax and emplaced in location $\# 9$.

FISCAL YEAR 1983

$04 / 07 / 83$

Received the STV. Transferred the canister to the Weld Pit. Removed the Climax shield plug and installed a lag storage shield plug. Transferred the cantster to the survey pit and swiped the exterior of the canister. transferred the canister to lag storage location 9. 
FUEL ASSEMBLY D01

DATE

$07 / 06 / 83$

Transferred the canister from lag storage location 9 to the Weld Pit. Removed the shield plug and performed a helium leak check. Obtained gas samples from the canister atmosphere. Performed a second leak check. Installed the shield plug and transferred the canister back to lag storage location 9 .

FISCAL YEAR 1984

$1 / 4 / 84$

Transferred the canister from lag storage location 9 to the Weld Pit. Removed the shield plug. Performed a helium leak check on the canister. Collected gas samples from the canister atmosphere. Performed a second leak check. Installed the canister shield plug. Transferred the canister back to lag storage location 9.

\section{$5 / 14 / 84$}

Transferred the canister from lag storage location 9 to the Weld Pit. Removed the shield plug. Performed a helium leak check on the canister. Collected gas and full volume fitration samples samples from the canister atmosphere. Installed the canister shield plug. Transferred the canister to the canister cutter. The canister was cut open. The fuel assembly was engaged with the calorimeter grapple and placed into a canister in the Weld Pit. A temporary canister lid was installed.

$5 / 15 / 84$

The temporary canister lid was removed. The fuel assembly was grappled using the calorimeter grapple and the 4 sides of the fuel assembly were videotaped. Visual examination and photodocumentation were performed at window E-2. The fuel assembly was transferred to the Survey Pit where integrity monitoring and contamination characterization swipes were taken on designated fuel rod surfaces. The fuel was transferred to window E-2. Post-swipe photos were taken, then the fuel was transferred to the Weld pit. The fuel was placed into the canister in the Weld Pit. The grapple was disengaged and a temporary lid installed on the canister.

\section{$5 / 16 / 84$}

Removed the temporary canister 1id. Three pressure plugs, 3 MIT capsule assemblies and 1 TPC assembly were removed from their guide tube locations. A temporary lid installed on the cantster. The shield plug was installed and the canister was transferred to lag storage location 9. 
FUEL ASSEMBLY DOI

FISCAL YEAR 1985

DATE

$12 / 10 / 84$

Transferred the canister from lag storage location 9 to the Weld Pit. Removed the shield plug and temporary canister lid. Fuel assembly engaged using the calorimeter grapple and transferred to the Survey Pit. The 16 integrity monitoring swipe samples taken. The fuel assembly was transferred back to the canister in the Weld Pit. The temporary canister lid and shield plug were reinstalled and the canister transferred back to lag storage location 9.

$4 / 2 / 85$

Transferred the canister from lag storage location 9 to the Weld Pit. Removed the shield plug and temporary canister 1id. Fuel assembly engaged using the calorimeter grapple and transferred to the Survey Pit. The 16 integrity monitoring swipe samples taken. The fuel assembly was transferred back to the canister in the Weld Pit. The temporary canister lid and shield plug were reinstalled and the canister transferred back to lag storage location 9.

FISCAL YEAR 1986

$5 / 86$

Removed the fuel assembly from the canister, performed visual inspection, and loaded assembly in shipping cask for motor transportation to INEL. 
HANDLING HISTORY OF FUEL ASSEMBLY D04

$\begin{array}{ll}\text { Fuel Serial Number: } & \text { D04/LMO 141 } \\ \text { Date Irradiation Started: } & 12 / 12 / 74 \\ \text { Date Irradiation Ended: } & 11 / 19 / 77 \\ \text { Burnup: } & 28,430 \mathrm{MWD} / \mathrm{MTU} \\ \text { Activities Prior to Receipt at E-MAD: }\end{array}$

Precharacterization at BCL,

9 Fuel Rods Removed and Tested, 5 Fuel

Rods and 4 Dummy Steel Rods Reinstalled

MIT Coupons Installed

Received at EMAD:

$12 / 11 / 79$

By Shipping Cask:

NLI $1 / 2$

DATE

$12 / 11 / 79$

Shipping cask received, fuel assembly transferred to a canister in the Weld Pit, lid screwed on canister but not welded. Shield plug installed and canister transferred to lag storage location $\$ 20$.

$01 / 23 / 80$

Transferred to the Weld Pit, checked the location of the canister thermocouple channe1s. Returned to lag storage location \#20.

$02 / 15 / 80$

Transferred to the Weld Pit, switched to Climax shield plug, checked alignment of canister $\mathrm{T} / \mathrm{C}$ channels by insertion of wire, switched back to lag storage plug, and returned to lag storage location $\$ 20$.

$04 / 09 / 80$

Canister moved to Weld Pit, shield plug removed. Gas sample taken from the unwelded canister. Shield plug reinstalled and canister transferred to lag storage location $\$ 20$.

$05 / 20 / 80$

Placed in the calorimeter, performed calorimetry $(1.385 \mathrm{~kW})$ and placed in a canister in the Weld Pit, installed screw on lid. Welding initiated but aborted due to seal weld flame-out. Left in the Weld Pit overnight for Weld Pit Calorimetry.

$05 / 21 / 80$

Installed Climax shield plug and transferred to the Transfer Pit. 
FUEL ASSEMBLY D04

DATE

$05 / 23 / 80$

Transferred to the Weld Pit, rewelded, backfilled with hellum, leak checked, installed Climax shield plug and moved to the Transfer Pit.

$05 / 27 / 80$

Loaded into the Surface Transport Vehicle.

$05 / 28 / 80$

Released for transport to Climax. Transported to Climax and emplaced in location \#11.

$08 / 17 / 82$

Received from Climax, loaded into lag storage location \#24.

$08 / 19 / 82$

Transferred to the Weld Pit, gas samples taken, LSP shield plug installed, placed in lag storage location \#21.

*NOTE: The measured decay heat rate of fuel assembly D04 may be in error, in that there is a significant difference between the measured and predicted decay heat rates.

FISCAL YEAR 1983

$08 / 02 / 83$

Transferred the canister from lag storage location 21 to the weld pit. Removed the shield plug and performed a helium leak check. Obtained gas samples from the canister atmosphere. Performed a second leak check. Installed the shield plug and transferred the canister to lag storage location 21 .

FISCAL YEAR 1984

$1 / 4 / 84$

Transferred the canister from lag storage location 21 to the Weld Pit. Removed the shield plug. Performed a helium leak check on the canister.

$1 / 5 / 84$

Collected gas samples from the canister atmosphere. Performed a second leak check. Installed the canister shield plug. Transferred the canister back to lag storage location 21 . 
FUEL ASSEMBLY D04

DATE

$5 / 21 / 84$

Transferred the canister from lag storage location 21 to the Weld Pit. Removed the shield plug. Performed a helium leak check on the canister. Collected gas and full volume filtration samples from the canister atmosphere. Installed the canister shield plug. Transferred the canister to the canister cutter. The canister was cut open. The fuel assembly was grappled using the calorimeter grapple and removed from the cut canister. The 4 sides of the fuel assembly were videotaped. The fuel assembly was placed into a canister in the Weld Pit. One of the pressure plugs in a guide tube location holding an MIT capsule was loosened, but could not be removed. A temporary lid was installed on the canister.

\section{$5 / 22 / 84$}

The temporary canister $11 d$ was removed. The fuel assembly was grappled using the calorimeter grapple. Visual examination and photodocumentation was performed at window E-2. The fuel assembly was transferred to the Survey P1t where integrity monitoring and contamination characterization swipes were taken on designated fuel rod surfaces. The fuel assembly was transferred to window E-2. Post-swipe photos were taken, then the fuel was transferred to the Weld pit. The fuel was placed into the canister in the Weld Pit. The grapple was disengaged. The 2 remaining pressure plugs, 3 MIT capsule assemblies and 1 TPC assembly were removed from their guide tube locations. A temporary lid installed on the canister.

$5 / 23 / 84$

The shield plug was installed on the canister and the canister transferred to lag storage location 21 .

FISCAL YEAR 1985

$12 / 12 / 84$

Transferred the canister from lag storage location 21 to the Weld P1t. Removed the shield plug and temporary canister 1id. Fuel assembly engaged using the calorimeter grapple and transferred to the Survey Pit. The 16 integrity monitoring swipe samples taken. The fuel assembly was transferred back to the canister in the Weld Pit. The calorimeter grapple latching bolt broke while trying to disengage the tool from the fuel assembly, but it was subsequently removed remotely. The tool latch nut, which had fallen onto the top of the fuel was retrieved. The temporary cantster lid and shield plug were reinstalled and the canister transferred back to lag storage location 21 . 
FUEL ASSEMBLY D04

DATE

$4 / 3 / 85$

Transferred the canister from lag storage location 21 to the Weld Pit. Removed the shield plug and temporary canister lid. Fuel assembly engaged using the calorimeter grapple and transferred to the Survey Pit. The 16 integrity monitoring swipe samples taken. The fuel assembly was transferred back to the canister in the Weld Pit. The temporary canister lid and shield plug were reinstalled and the canister transferred back to lag storage location 21 .

$8 / 27 / 85$

Transferred the canister from lag storage location 21 to the Weld Pit. Removed the shield plug and temporary canister lid. Fuel assembly engaged using the calorimeter grapple and transferred to the calorimeter. Initiated thermal stabilization of the system.

$8 / 28 / 85$

The decay heat rate of the fuel assembly was measured at $0.487 \mathrm{~kW}$. The fuel was removed from the calorimeter and transferred to the canister in the Weld Pit. Installed a temporary canister 11d and shield plug. Transferred the canister to lag storage location 21.

FISCAL YEAR 1986

$5 / 86$

Removed the fuel assembly from the canister, performed visual inspection, and loaded assembly in shipping cask for motor transportation to INEL. 
HANDLING HISTORY OF FUEL ASSEMBLY D06

$\begin{array}{ll}\text { Fuel Serial Number: } & \text { D06/LMO } 144 \\ \text { Date Irradiation Started: } & 12 / 12 / 74 \\ \text { Date Irradiation Ended: } & 11 / 19 / 77 \\ \text { Burnup: } & 28.430 \mathrm{MWD} / \mathrm{MTU} \\ \text { Activities Prior to Receipt at EMAD: }\end{array}$

Precharacterization performed at BCL, 9 Fuel Rods Removed and Tested, 5 fuel rods and 4 dummy steel rods reinstalled MIT Coupons Installed

Received at EMAD: $11 / 30 / 79$

By Shipping Cask:

NLI $1 / 2$

DATE

$11 / 30 / 79$

Shipping cask recelved, fuel assembly transferred to a canister in the Weld Pit and a lid installed. Canister seal welded, backfilled with helium, and leak checked. Canister transferred to lag storage location \#19.

$01 / 23 / 80$

Moved to the Weld Pit, checked locations of canister thermocouple channels, ret irned to lag storage location 19.

$02 / 14 / 80$

Moved to the Weld Pit, switched to Climax shield plug, checked alignment to canister $T / C$ channels by inserting wires, switched back to lag storage shield plug, and returned to lag storage location 19.

$05 / 12 / 80$

Moved to Weld Pit, switched to Climax shield plug and loaded into Surface Transport Vehicle.

$05 / 12 / 80$

Released for transport to Climax. Transported to Climax and emplaced in location \#8.

$10 / 27 / 81$

Received from Climax (second exchange) and placed in lag storge location \#23.

$06 / 25 / 82$

Transferred to the Weld Pit. Leak check performed on the canister, gas sample taken from canister, a second leak check performed on the canister and returned to lag storage location $\$ 23$. 
FUEL ASSEMBLY D06

FISCAL YEAR 1983

DATE

$10 / 05 / 82$

Instrumented the canister in lag storage location 23 to monitor temperature.

$06 / 20 / 83$

Transferred the canister from lag storage location 23 to the Weld Pit. Removed the Climax shield plug. Performed a hellum leak check. Obtained gas and full volume filtration samples from the canister atmosphere. Installed a lag storage shield plug. Transferred the canister to the canister cutter.

$06 / 21 / 83$

Initiated cutting of the canister. At about 230 degrees around the canister, the cutter blade broke. A replacement blade was installed and the cut completed. The fuel assembly was removed from the canister and the 4 sides videotaped. The fuel assembly was placed into an empty canister in the Weld Pit. The fuel handling tool was left engaged to the fuel assembly.

$06 / 22 / 83$

The fuel assembly was removed from the canister. Visual examination and photography of the fuel was performed at window E- 2. The fuel assembly was placed into an empty canister in the Weld Pit. The fuel handing tool was left engaged to the fuel assembly.

$06 / 23 / 83$

The fuel assembly was removed from the canister and transported to the survey pit. Integrity monitoring and contamination characterization swipes were taken on designated fuel rod surfaces. The fuel assembly was transported to window E-2 for taking of post-swipe examination and photography. The fuel assembly was then placed into an empty canister in the Weld Pit. A temporary canister lid and a shield plug were installed. The canister was transferred to lag storage location 22.

$06 / 24 / 83$

Instrumented the canister to monitor temperature. 
FUEL ASSEMBLY D06

FISCAL YEAR 1984

DATE

$1 / 19 / 84$

Transferred the canister from lag storage location 22 to the Weld Pit. Removed the shield plug and temporary canister lid. Engaged the fuel assembly with the calorimeter grapple and transferred the fuel to the survey pit. Obtained integrity monitoring swipes from designated fuel rod surfaces. Transferred the fuel back to the canister in the Weld Pit and disengaged the grapple. A pressure plug was removed from one guide tube location containing an MIT capsule assembly. Unsuccessfully attempted to engage the lifting eye of the MIT assembly. Engaged the Temperature Profile Capsule TPC assembly lifting pintle and then released the TPC. Installed the temporary $11 \mathrm{~d}$ and the shield plug. Transferred the canister back to 1 ag storage location 22 .

$4 / 10 / 84$

Transferred the canister from lag storage location 22 to the Weld Pit. Removed the shield plug and temporary canister lid. Two pressure plugs, 3 MIT capsule assemblies and 1 TPC assembly were removed from their guide tube locations. A temporary lid installed on the canister. The shield plug was installed and the canister was transferred to lag storage location 22.

$6 / 13 / 84$

Transferred the canister from lag storage location 22 to the Weld Pit. Removed the shield plug and temporary canister lid. Engaged the fuel assembly with the calorimeter grapple and transferred the fuel to the survey pit. Obtained integrity monitoring swipes from designated fuel rod surfaces. Transferred the fuel back to the canister in the Weld Pit and disengaged the grapple. Installed the temporary lid and the shield plug. Transferred the canister back to lag storage location 22.

FISCAL YEAR 1985

\section{$12 / 13 / 84$}

Transferred the canister from lag storage location 22 to the Weld Pit. Removed the shield plug and temporary canister lid. Fuel assembly engaged using the PWR Fuel Handling Tool and transferred to the Survey Pit. The 16 integrity monitoring swipe samples taken. The fuel assembly was transferred back to the canister in the Weld Pit. The temporary canister lid and shield plug were reinstalled and the canister transferred back to lag storage location 22 . 
FUEL ASSEMBLY D06

DATE

$4 / 8 / 85$

Transferred the canister from lag storage location 22 to the Weld Pit. Removed the shield plug and temporary canister lid. Fuel assembly engaged using the calorimeter grapple and transferred to the Survey Pit. The 16 integrity monitoring swipe samples taken. The fuel assembly was transferred back to the canister in the Weld Pit. The temporary canister lid and shield plug were reinstalled and the canister transferred back to lag storage location 22.

$9 / 6 / 85$

Transferred the canister from lag storage location 22 to the Weld Pit. Removed the shield plug and temporary canister lid. Removed the upper nozzle access plug. Using a special fixture, checked capability of the PWR fuel rod handling tool to engage the accessible fuel rods. Sixteen of the 20 rods were successfully engaged. Rods at locations F7, G10, I6, and J7 could not be engaged. The rods at locations F7, G10, and I6 were steel rods installed by BCL to replace fuel rods removed for destructive examination. The rods at these locations were inserted too far into the fuel assembly to be gripped with the E-MAD fuel rod handling tool. Installed a temporary canister lid and shield plug. Transferred the canister to lag storage location 22.

$9 / 17 / 85$

Transferred the canister from lag storage location 22 to the Weld Pit. Removed the shield plug and temporary canister lid. Attempted to engage the steel rod at location J9. Engagement could not be achleved. At tempted to engage 2 other rods and they also could not be engaged. Reinstalled the temporary canister lid and shield plug. Transferred the canister to lag storage location 22 .

$9 / 19 / 85$

Transferred the canister from lag storage location 22 to the Weld Pit. Removed the shield plug and temporary canister lid. Engaged and raised fuel rods at locations F8, G8, I8, F9, G9, H9, I9, H10, and I10 about 2 feet, measuring the breakout and reinsertion forces. Installed the temporary canister lid.

$9 / 20 / 85$

Removed the temporary canister lid. Engaged and raised fuel rods at locations J8, G7, H7, I7, G6, and H6 about 2 feet, measuring the breakout and reinsertion forces. Reinstalled the access plug in the upper fuel assembly nozzle. Installed the temporary canister lid and shield plug. Transferred the canister to lag storage location 22.

FISCAL YEAR 1986

$5 / 86$

Removed the fuel assembly from the canister, performed visual inspection, and loaded assembly in shipping cask for motor transportation to INEL. 
HANDLING HISTORY OF FUEL ASSEMBLY D09

Fuel Serial Number: D09/LMO 143

Date Irradiation Started: 12/12/74

Date Irradiation Ended: $11 / 19 / 77$

Burnup :

27,863 MWD/MTU

Received at EMAD:

$10 / 09 / 79$

By Shipping Cask:

NLI $1 / 2$

\section{DATE}

$10 / 09 / 79$

Shipping cask received, fuel assembly transferred to a canister in the weld pit, and a lid installed. Canister seal welded, backfilled with helium, and leak checked.

$10 / 10 / 79$

Shield plug installed and canister transferred to lag storage location \#12.

$01 / 22 / 80$

Moved to the Weld Pit, checked the locations of the canister thermocouple channels, returned to lag storage location \#12.

$02 / 13 / 80$

Moved to the Weld Pit, switched to Climax shield plug, checked alignment of canister T/C channels by inserting wires, switched back to lag storage shield plug, and returned to lag storage location 12 .

$04 / 30 / 80$

Moved to Weld Pit, switched to Climax shield plug and loaded into Surface Transport Vehicle.

$05 / 01 / 80$

Released for transport to Climax. Transported to $\mathrm{Climax}$ and emplaced in location $\$ 5$.

$01 / 13 / 81$

Returned from Climax (first exchange), placed in lag storage location \#24.

$10 / 27 / 81$

Loaded into Surface Transport Vehicle.

$10 / 28 / 81$

Released for transport to Climax. Transported to $\mathrm{Climax}$ and emplaced in location \#8. 
FUEL ASSEMBLY D09

FISCAL YEAR 1983

DATE

$03 / 30 / 83$

Received the STV. Transferred the canister to the Weld Pit. Removed the Climax shield plug and installed a lag storage shield plug. Transferred the canister to the Survey $\mathrm{P} i \mathrm{t}$ and swiped the exterior of the canister. Transferred the canister to lag storage location 12.

$06 / 29 / 83$

Transferred the canister from lag storage location 12 to the Weld Pit. Removed the shield plug. Performed a hellum leak check. Obtained gas samples from the canister atmosphere. Performed a second canister leak check but excessive leakage was noted. The vent cap fitting was retightened and a third leak check performed. Leakage was acceptable. Placed a shield plug on the canister but the support pins were not threaded into the plug.

$06 / 30 / 83$

Threaded the support pins into the shield plug. Transferred the canister to lag storage location 12.

FISCAL YEAR 1984

$1 / 5 / 84$

Transferred the canister from lag storage location 12 to the Weld Pit. Removed the shield plug. Performed a helium leak check on the canister. Collected gas samples from the canister atmosphere. Performed a second leak check. Installed the canister shield plug. Transferred the canister bark to lag storage location 12.

\section{$2 / 13 / 84$}

Transferred the canister from lag storage location 12 to the Transfer Pit. Transferred the canister to drywell 1 using the EIV shield. The drywell instrumentation was installed and thermal monitoring of the canister, liner, and surrounding soll initiated.

$7 / 23 / 84$

Transferred the canister from drywell 1 to the Transfer Pit using the EIV shield. Locomotive $\mathrm{L}-5$ used as the prime mover. Transferred the canister to the Weld Pit. Removed the shield plug. Performed a helium leak check on the canister. Collected gas samples from the canister atmosphere. Performed a second leak check. Installed the canister shield plug. Transferred the canister back to the Transfer Pit. Transferred the canister back to drywell 1 using the EIV shield. The drywell instrumentation was installed and thermal monitoring of the canister, liner, and surrounding soil continued. 
FUEL ASSEMBLY D09

FISCAL YEAR 1985

DATE

$10 / 23 / 84$

Canister transferred from drywell 1 to the Transfer Pit and on to LSP

10.

\section{$11 / 26 / 84$}

Transferred the canister from lag storage location 10 to the Weld Pit. Removed the shield plug and performed a helium leak check. Installed the gas sampling plenum and took gas samples of the canister atmosphere. Performed a helium leak check on the cantster. Installed the shield plug and transferred the canister back to lag storage location 10 .

\section{$3 / 4 / 85$}

Transferred the canister from lag storage location 10 to the Weld Pit. Removed the shield plug and performed a helium leak check. Installed the gas sampling plenum and took gas samples of the canister atmosphere. Performed a full volume filtration of the atmosphere of the canister through a 0.45 micron filter and then vented to atmosphere. Installed the shield plug and transferred the canister to the Canister Cutter. Cut the cantster open. Placed a cover over the fuel assembly upper nozzle.

$3 / 5 / 85$

Removed the cover from over the fuel assembly. Removed the fuel assembly using the calorimeter grapple. Videotaped the 4 sides of the fuel assembly. Transferred the fuel to the window E-2 inspection location. Inspected and photographed the fuel. Transferred the fuel to the Survey Pit. Took contamination characterization and integrity monitoring swipes from designated fuel rods. Transferred the fuel to the window E- 2 insfection location. Photographed designated areas that had been swiped. Transferred the fuel assembly to an empty canister in the Weld Pit and installed a temporary canister lid. Installed the shield plug and transferred the canister to lag storage location 10.

$7 / 10 / 85$

Transferred the canister from lag storage location 10 to the Weld Pit. Removed the shield plug and temporary canister lid. Fuel assembly engaged using the calorimeter grapple and transferred to the Survey Pit. The 16 integrity monitoring swipe samples taken. The fuel assembly was transferred back to the canister in the Weld Pit. The temporary canister lid and shield plug were relnstalled and the canister transferred back to lag storage location 10 .

FISCAL YEAR 1986

$5 / 86$

Removed the fuel assembly from the canister, performed visual inspection, and loaded assembly in shipping cask for motor transportation to INEL. 


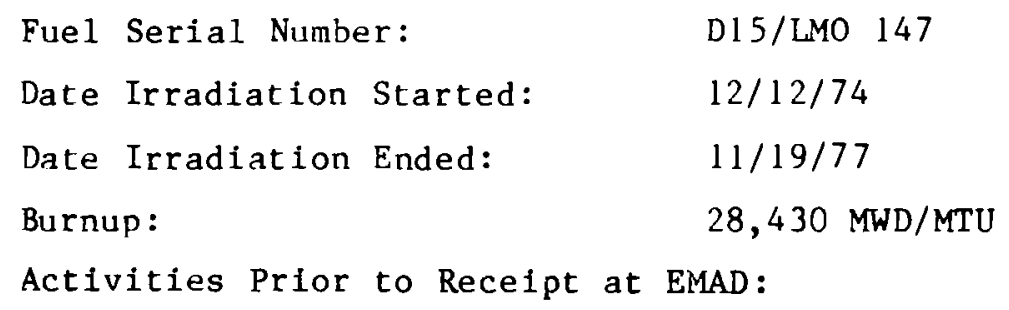

DATE

$11 / 26 / 79$

Received shipping cask and prepared for unloading.

$11 / 27 / 79$

Moved fuel assembly to a canister in the Weld Pit, screwed lid in place, installed shield plug, and moved to lag storage location \#18.

$01 / 23 / 80$

Moved to the Weld Pit, checked the locations of the canister thermocouple channels, and returned to lag storage location \#18.

$02 / 15 / 80$

Moved to the Weld Pit, switched to Climax shield plug, checked alignment of the canister thermocouple channels by insertion of wires, switched back to lag storage shield plug, and transferred back to lag storage location 非8.

$04 / 10 / 80$

Moved to the Weld Pit, removed shield plug, obtained gas sample from canister, reinstalled shield plug and returned to lag storage location 18.

$06 / 04 / 80$

Moved to lag storage location \#15.

$07 / 08 / 80$

Moved to the Weld Pit, transferred the fuel to the calorimeter and performed calorimetry $(1.423 \mathrm{~kW})$, then placed the fuel in a canister with a threaded lid overnight for Weld Pit calorimetry. 
FUEL ASSEMBLY D 15

DATE

$07 / 09 / 80$

Placed the canister in lag storage location \#15.

$09 / 22 / 80$

Transferred the canister to the Weld Pit, moved the fuel to the Fuel Assembly Internal Temperature Measurement (FAITM) Test stand canister, installed the 1id.

$09 / 23 / 80$

Tightened the FAITM Test stand lid tie down nuts and transferred the FAITM Test stand canister to the West Process Cell.

$09 / 26 / 80$

Initiated Running Test 1 - "Air Calibration."

$09 / 30 / 80$

Stabilization achieved on Test 1, completed Test 2 - "Vacuum Calibration."

10/03/80

Completed Test 3 - "Helium Calibration."

$10 / 08 / 80$

Completed Test 13 - "Air/Uniform $350^{\circ} \mathrm{F}$ Canister," profile could not be at tained.

10/10/80

Completed Test 14 - "Air/Uniform $400^{\circ}$ F Canister."

$10 / 17 / 80$

Completed Test 16 - "Air/Uniform $500^{\circ}$ F Canister."

$10 / 20 / 80$

Completed Test 22 - "Vacuum/Uni form $500^{\circ}$ F Canister."

$10 / 22 / 80$

Completed Test 28 - "Helium/Uniform $500^{\circ}$ F Canister."

$10 / 27 / 80$

Completed Test 26 - "Hellum/Uniform $400^{\circ}$ F Canister."

$10 / 31 / 80$

Completed Test 20 - "Vacuum/Uniform $400^{\circ}$ F Canister."

$11 / 03 / 80$

Completed Test 21 - "Vacuum/Uniform $450^{\circ}$ F Canister."

$11 / 05 / 80$

Completed Test 27 - "Helium/Uniform $450^{\circ}$ F Canister." 
FUEL ASSEMBLY D15

DATE

$11 / 07 / 80$

Completed Test 15 - "Air/Uniform $450^{\circ}$ F Canister."

$11 / 12 / 80$

Completed Test 17 - "Air/Uniform $550^{\circ}$ F Canister."

$11 / 14 / 80$

Completed Test 23 - "Vacuum/Uniform $550^{\circ} \mathrm{F}$ Canister."

$11 / 17 / 80$

Completed Test 29 - "Helium/Uniform $550^{\circ}$ F Canister."

$11 / 20 / 80$

Test 30 - "Helium/Uniform $600^{\circ} \mathrm{F}$ Canister."

$12 / 08 / 80$

Completed Test 7 - "Air Drywe 11 Canister."

$12 / 10 / 80$

Completed Test 8 - "Vacuum Drywel1 Canister."

$12 / 14 / 80$

Completed Test 9 - "Helium Drywell Canister."

$12 / 19 / 80$

Completed Test 4 - "Helium Electrically Heated Drywell Test Canister."

$12 / 22 / 80$

Completed Test 10 - "Helium SFT-C Canister."

$12 / 27 / 80$

Completed Test 11 - "Vacuum SFT-C Canister."

$12 / 31 / 80$

Completed Test 5 - "Vacuum Electrically Heated Drywell Test Canister."

$01 / 05 / 80$

Completed Test 31 - "Air Calibration (Final)."

$01 / 05 / 81$

Transferred the FAITM Test Stand Canister to the Hot Bay.

$01 / 06 / 81$

Moved the fuel to a canister in the Weld Pit, transferred the fuel assembly to the calorimeter, performed calorimetry $(1.126 \mathrm{~kW})$, transferred the fuel assembly to a canister in the Weld Pit, installed a threaded $1 \mathrm{id}$, and left the canister in the Weld Pit overnight for Weld Pit calorimetry. 
FUEL ASSEMBLY D15

DATE

$01 / 07 / 81$

Performed seal weld on the canister, backfilled with helium, leak checked the canister, installed a Climax shield plug and placed the canister in lag storage location \#23.

$01 / 13 / 81$

Transferred the canister to the Surface Transport Vehicle.

$01 / 14 / 81$

Released the STV for transport of the canister to Climax. Canister emplaced in Climax location 非.

FISCAL YEAR 1983

$03 / 23 / 83$

Received the STV. Transferred the canister to the Survey PIt and swiped the exterior of the canister. Transferred the canister to the transfer pit.

$03 / 24 / 83$

Transferred the canister to the Weld Pit. Removed the Climax shield plug. Performed a helium leak check. Obtained gas samples from the canister atmosphere. Performed a second canister leak check. Installed a lag storage shield plug. Transferred the canister to lag storage location 14.

$07 / 25 / 83$

Transferred the canister from lag storage location 14 to the Weld Pit. The shield plug was removed and a canister leak check was performed. Gas and full volume filtration samples of the canister atmosphere were taken from the canister atmosphere. The shield plug was placed on the canister but not attached.

$07 / 26 / 83$

The support pins were threaded into the shield plug. The canister was transferred to the canister cutter and the canister was cut open. The fuel assembly was engaged with the calorimeter grapple and removed from the cut canister. The 4 sides of the fuel were videotaped. The fuel assembly was transported to window E-2 and the visual examination and photodocumentation was partially completed. The fuel assembly was placed into an empty canister in the Weld Pit and the grapple disengaged.

$07 / 27 / 83$

The fuel assembly was engaged with the calorimeter grapple and transported to window E-2 for completion of inspection and photodocumentation. The fuel assembly was transported to the Survey Pit. Integrity monitoring and contamination characterization swipes were taken on designated fuel rod surfaces. Post-swipe inspection and photography was performed at window $\mathrm{E}-2$. The fuel assembly was placed into the empty canister in the Weld Pit and the fuel grapple was disengaged. 
FUEL ASSEMBLY D 15

DATE

$07 / 28 / 83$

The fuel assembly was engaged with the calorimeter grapple, removed from the canister and placed into the calorimeter vessel. The decay heat rate of the fuel assembly was measured at $0.625 \mathrm{~kW}$ using boiling water calorimetry. The fuel assembly was removed from the calorimeter and transported to window E- 2 for inspection and photodocumentation. The fuel was then transported to the Survey Pit for post-calorimetry swipes from designated fuel rod surfaces. The fuel was returned to window E-2 for post-swipe inspection and photography. The fuel was placed into the empty canister in the Weld Pit and the grapple disengaged.

$08 / 29 / 83$

A temporary canister lid and a shield plug were installed on the canister. The canister was transferred to lag storage location 14.

FISCAL YEAR 1984

$1 / 23 / 84$

Transferred the canister from lag storage location 14 to the Weld Pit. Removed the shield plug and temporary canister lid. Engaged the fuel assembly with the calorimeter grapple and transferred the fuel to the survey pit. Obtained integrity monitoring swipes from designated fuel rod surfaces. Transferred the fuel back to the canister in the Weld Pit and disengaged the grapple. Installed the temporary lid and the shield plug. Transferred the canister back to lag storage location 14 .

$6 / 13 / 84$

Transferred the canister from lag storage location 14 to the Weld Pit. Removed the shield plug and temporary canister 1id. Engaged the fuel assembly with the calorimeter grapple and transferred the fuel to the survey pit. Obtained integrity monitoring swipes from designated fuel rod surfaces. Transferred the fuel back to the canister in the Weld Pit and disengaged the grapple. Installed the temporary lid and the shield plug. Transferred the canister back to lag storage location 14 .

FISCAL YEAR 1985

$12 / 14 / 84$

Transferred the canister from lag storage location 14 to the Weld Pit. Removed the shield plug and temporary canister lid. Fuel assembly engaged using the PWR Fuel Handling Tool and transferred to the Survey Pit. The 16 integrity monitoring swipe samples taken. The fuel assembly was transferred back to the canister in the Weld Pit. The temporary canister lid and shield plug were reinstalled and the canister transferred back to lag storage location 14. 
FUEL ASSEMBLY D 15

DATE

$4 / 3 / 85$

Transferred the canister from lag storage location 14 to the Weld Pit. Removed the shield plug and temporary canister lid. Fuel assembly engaged using the calorimeter grapple and transferred to the Survey Pit. The 16 integrity monitoring swipe samples taken. The fuel assembly was transferred back to the canister in the Weld Pit. The temporary canister lid and shield plug were reinstalled and the canister transferred back to lag storage location 14 .

$8 / 21 / 85$

Transferred the canister from lag storage location 14 to the Weld Pit. Removed the shield plug and temporary canister lid. Fuel assembly engaged using the calorimeter grapple and transferred to the calorimeter. Initiated thermal stabilization of the system.

$8 / 22 / 85$

The decay heat rate of the fuel assembly was measured at $0.506 \mathrm{~kW}$. The fuel was removed from the calorimeter and transferred to the canister in the Weld Pit. Installed a temporary canister lid and shield plug. Transferred the canister to lag storage location 14.

FISCAL YEAR 1986

$5 / 86$

Removed the fuel assembly from the canister, performed visual inspection, and loaded assembly in sh1pping cask for motor transportation to INEL. 
Fuel Serial Number: D16/LMO 149

Date Irradiation Started: 12/12/74

Date Irradiation Ended: $\quad 11 / 19 / 77$

Burnup :

$27,863 \mathrm{MWD} / \mathrm{MTU}$

Received at EMAD:

$10 / 22 / 79$

By Shipping Cask:

NLI $1 / 2$

DATE

$10 / 22 / 79$

Shipping cask received, fuel assembiy transferred to a canister in the Weld P1t, and a lid installed. Canister seal welded, backfilled with helium, leak checked, and transferred to lag storage location \#14.

$01 / 22 / 80$

Moved to the Weld Pit, checked the locations of the canister thermocouple

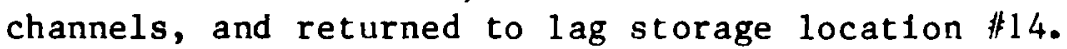

$02 / 12 / 80$

Moved to the Weld Pit, switched to Climax shield plug, checked alignment of the canister thermocouple channels by insertion of wires, switched back to lag storage shield plug and transferred to lag storage location 14.

$04 / 23 / 80$

Moved to the Weld Pit to prepare for shipment to Climax. Support pin stuck during removal of the lag storage shield plug. Returned to the lag storage pit \#14.

$05 / 19 / 80$

Moved to Weld P1t, removed shield plug by machining support pin, installed Climax shield plug and loaded into Surface Transport Vehicle.

$05 / 20 / 80$

Released for transport to Climax. Transported to Climax and emplaced in location 10 .

FISCAL YEAR 1983

$04 / 05 / 83$

Received the STV. Transferred the canister to the Weld Pit. Removed the Climax shield plug and installed a lag storage shield plug. Transferred the canister to the Survey Pit and swiped the exterior of the canister. Transferred the canister to lag storage location 10 . 
FUEL ASSEMBLY D 16

DATE

$07 / 05 / 83$

Transferred the canister from lag storage location 10 to the Weld Pit. Removed the shield plug. Performed a helium leak check. Obtained gas samples from the canister atmosphere. Performed a second canister leak check. Installed a lag storage shield plug. Transferred the canister to lag storage location 10 .

FISCAL YEAR 1984

$1 / 6 / 84$

Transferred the canister from lag storage location 10 to the Weld Pit. Removed the shield plug. Performed a helium leak check on the cantster. Collected gas samples from the canister atmosphere. Performed a second leak check. Installed the canister shield plug. Transferred the canister back to lag storage location 10 .

$5 / 30 / 84$

Transferred the canister from lag storage location 10 to the Weld Pit. Removed the shield plug. Performed a helium leak check on the canister. Collected gas samples from the canister atmosphere. Performed a second leak check. Installed the canister shield plug. Transferred the canister back to lag storage location 10 .

\section{$6 / 5 / 84$}

Transferred the canister from lag storage location 10 to the Survey Pit. Swipe samples were taken on the exterior surface of the canister. The canister was transferred to the Transfer Pit. Transferred the canister back to drywell 3 using the EIV shield. The drywell instrumentation was installed and thermal monitoring of the canister, liner, and surrounding soil initiated.

FISCAL YEAR 1985

$10 / 24 / 84$

Canister transferred from drywell 3 to the Transfer Pit and on to LSP 7.

$11 / 27 / 84$

Transferred the canister from lag storage location 7 to the Weld Pit. Removed the shield plug and performed a helium leak check. Installed the gas sampling plenum and took gas samples of the canister atmosphere. Performed a helium leak check on the canister. Installed the shield plug and transferred the canister back to lag storage location 7. 
FUEL ASSEMBLY D16

DATE

$4 / 25 / 85$

Transferred the canister from lag storage location 7 to the Weld Pit. Removed the shield plug and performed a helium leak check. Installed the gas sampling plenum and took gas samples of the canister atmosphere. Performed a full volume filtration of the atmosphere of the canister through a 0.45 micron filter and then vented to atmosphere. Installed the shield plug and transferred the canister back to lag storage location 7.

$6 / 4 / 85$

Transferred the canister from lag storage location 7 to the Canister Cutter. Cut the canister open. Engaged the fuel assembly with the calorimeter grapple and videotaped the 4 sides of the fuel assembly. Returned the fuel assembly into the cut canister in the Canister Cutter.

$6 / 5 / 85$

Engaged the fuel assembly with the calorimeter grapple and transported the assembly to the inspection station at window E-2. Obtained a photomosaic of the 0 degree face of the assembly. Performed a visual inspection of the assembly. Obtained photographs of the areas to be swiped. Transferred the assembly to the Survey Pit and obtained contamination characterization swipes. Returned the assembly to the inspection station at window $\mathrm{E}-2$ and rephotographed the swipe areas. Placed the fuel assembly in the temporary storage canister in the Weld Pit. Installed a temporary canister lid.

\section{$6 / 6 / 85$}

Removed the temporary canister lid and engaged the fuel assembly with the calorimeter grapple. Transferred the assembly to the Survey Pit and obtained integrity monitoring swipes. Returned the fuel assembly to the temporary storage canister in the Weld Pit. Installed a temporary canister lid. Installed a shield plug on the canister. Transferred the canister to lag storage location 7 .

FISCAL YEAR 1986

$5 / 86$

Removed the fuel assembly from the canister, performed visual inspection, and loaded assembly in shipping cask for motor transportation to INEL. 
HANDLING HISTORY OF FUEL ASSEMBLY D 18

$\begin{array}{ll}\text { Fuel Serial Number: } & \text { D18/LMO } 148 \\ \text { Date Irradiation Started: } & 12 / 12 / 74 \\ \text { Date Irradiation Ended: } & 11 / 19 / 77 \\ \text { Burnup: } & 27,863 \mathrm{MWD} / \mathrm{MTU} \\ \text { Received at EMAD: } & 10 / 20 / 79 \\ \text { By Shipping Cask: } & \text { NLI } 1 / 2\end{array}$

DATE

$10 / 20 / 79$

Shipping cask recelved, fuel assembly transferred to a canister in the Weld Pit, and a lid installed. Canister seal welded, backfilled with hellum, leak checked, and transferred to lag storage location \#13.

$01 / 22 / 80$

Moved to the Weld PIt, checked the locations of the canister thermocouple channels, and transferred back to lag storage location \#13.

$02 / 12 / 80$

Moved to the Weld PIt, switched to Climax shleld plug, checked alignment of canister $\mathrm{T} / \mathrm{C}$ channels by insertion of wires, switched back to 1 ag storage shield plug and transferred back to lag storage location \#13.

$04 / 21 / 80$

Moved to Weld P1t, switched to Climax shield plug and loaded into Surface Transport Vehicle.

$04 / 22 / 80$

Released for transport to Climax. Transported to Climax and emplaced in location \#2.

FISCAL YEAR 1983

$04 / 01 / 83$

Recelved the STV. Transferred the canister to the Weld Pit. Removed the Climax shield plug and installed a lag storage shield plug. Transferred the canister to the Survey Pit and swiped the exterior of the canister. Transferred the canister to lag storage location 11 . 
FUEL ASSEMBLY D 18

DATE

$06 / 30 / 83$

Transferred the canister from lag storage location 11 to the Weld Pit. Removed the shield plug. Performed a hellum leak check. Obtained gas samples from the canister atmosphere. Performed a second canister leak check. Installed a lag storage shield plug. Transferred the canister to lag storage location 11 .

FISCAL YEAR 1984

$1 / 9 / 84$

Transferred the canister from lag storage location 11 to the Weld Pit. Removed the shield plug. Performed a hellum leak check on the canister. Collected gas samples from the canister atmosphere. Performed a second leak check. Installed the canister shield plug. Transferred the canister back to lag storage location 11 .

$7 / 16 / 84$

Transferred the cantster from lag storage location 11 to the Weld Pit. Removed the shield plug. Performed a hellum leak check on the canister. Collected gas samples from the canister atmosphere. Performed a second leak check. Installed the canister shield plug. Transferred the canister back to lag storage location 11 .

FISCAL YEAR 1985

$11 / 27 / 84$

Transferred the cantster from lag storage location 11 to the Weld Pit. Removed the shield plug and performed a helium leak check. Installed the gas sampling plenum and took gas samples of the canister atmosphere.

$11 / 28 / 84$

Performed a helium leak check on the canister. Installed the shield plug and transferred the canister back to lag storage location 11 .

$4 / 26 / 85$

Transferred the canister from lag storage location 11 to the Weld Pit. Removed the shield plug and performed a hellum leak check. Installed the gas sampling plenum and took gas samples of the canister atmosphere.

Performed a full volume filtration of the atmosphere of the canister through a 0.45 micron filter and then vented to atmosphere. Installed the shield plug and transferred the canister back to lag storage location 11.

$6 / 7 / 85$

Transferred the canister from lag storage location 11 to the Canister Cutter. Cut the canister open. Engaged the fuel assembly with the cal wimeter grapple and videotaped the 4 sides of the fuel assembly. Returned the fuel assembly into the cut canister in the Canister Cutter. Placed a temporary cover over the upper nozzle of the fuel assembly. 
FUEL ASSEMBLY D 18

DATE

$6 / 10 / 85$

Removed the cover from over the fuel assembly. Engaged the fuel assembly with the calorimeter grapple and transported the assembly to the inspection station at window E-2. Obtained a photomosalc of the 0 degree face of the assembly. Performed a visual inspection of the assembly. Obtained photographs of the areas to be swiped. Transferred the assembly to the Survey Pit and obtained characterization and integrity monitoring swipes. Returned the assembly to the inspection station at window $E-2$ and rephotographed the swipe areas. Placed the fuel assembly in the temporary storage canister in the Weld Pit. Installed a temporary canister lid and shield plug. Transferred the canister to lag storage location 11.

FISCAL YEAR 1986

$10 / 17 / 85$

Transferred the canister from lag storage location 11 to the weld pit. Removed the shield plug and temporary canister lid. Engaged the fuel assembly with the calorimeter grapple and raised the fuel assembly partially out of the canister. Removed foreign object from on top of the fuel rods with a magnet. Returned the fuel asembly into the canister. Installed the canister lid and shield plug. Transferred the canister back to lag storage location 11 .

FISCAL YEAR 1986

$5 / 86$

Removed the fuel assembly from the canister, performed visual inspection, and loaded assembly in shipping cask for motor transportation to INEL. 
HANDLING HISTORY OF FUEL ASSEMBLY D22

Fuel Serial Number:

D22/LMO $14 \mathrm{C}$

Date Irradiation Started:

$12 / 12 / 74$

Date Irradiation Ended:

$11 / 19 / 77$

Burnup:

$26,485 \mathrm{MWD} / \mathrm{MTU}$

Received at EMAD:

$11 / 12 / 79$

By Shipping Cask:

NLI $1 / 2$

DATE

$11 / 12 / 79$

Shipping cask received, fuel assembly placed in a canister in the Weld Pit, installed a screw-on lid, and placd in lag storage location 16.

$12 / 04 / 79$

$\mathrm{T} / \mathrm{C}$ installed for vault test.

$01 / 22 / 80$

Moved to the Weld Pit, checked the canister thermocouple couple alignment, and transferred to lag storage location \#16.

$02 / 15 / 80$

Moved to the Weld Pit, switched to Climax shield plug, checked alignment of the canister thermocouple channels by insertion of wires, reinstalled lag storage shield plug, and transferred back to lag storage location 16 .

$04 / 08 / 80$

Moved to Weld Pit for gas sampling. Support pin stuck, returned to lag storage location \#16 without removing shield plug.

$06 / 22 / 80$

$\mathrm{T} / \mathrm{C}$ removed.

$06 / 25 / 80$

Moved to the Weld Pit, cut support pin out and took gas samples from unwelded canister. Initiated calorimetry, but the calorimeter would not operate correctly. A shield plug was installed on the canister and it was placed in lag storage location 非2.

$07 / 09 / 80$

Moved the canister to the Weld Pit and placed the fuel assembly in the calorimeter. Performed calorimetry $(1.284 \mathrm{~kW})$, removed the fuel from the calorimeter and placed it in a canister. Installed a threaded lid and left the canister in the Weld Pit overnight for Weld Pit calorimetry.

$07 / 10 / 80$

Installed a shield plug and moved the canister to lag storage location $\#_{2} 2$. 
FUEL ASSEMBLY D22

DATE

$08 / 07 / 80$

Transferred the canister to the Weld Pit, performed seal weld, backfilled with helium, leak checked the canister, and placed the canister in lag storage location \#22.

$08 / 29 / 80$

Placed the canister in the external canister stand for the neutron count experiment.

$09 / 02 / 80$

Removed the canister from the external canister stand and placed the canister in lag storage location $\$ 22$.

$09 / 04 / 80$

Moved the canister to the Transfer Pit and transported the canister to Drywell \#5 with the EIV.

$09 / 05 / 80$

Initiated Phase II of the Isolated Drywell Test.

$04 / 06 / 81$

Completed Phase II of the Isolated Drywell Test. Data Collection continued to monitor thermal condition of drywell.

$06 / 28 / 82$

Transported the canister to the Hot Bay using the EIV, placed the canister in the Transfer Pit. Moved the canister to the Weld Pit, performed a leak cherk on the canister, and obtained gas samples. Canister left in the We1! Pit overnight.

$06 / 29 / 82$

Performed a canister leak check, moved the canister back to the Transfer Pit and transported the canister to Drywell \#5 with the EIV.

$08 / 12 / 82$

Removed from Drywe11 \#5 and transported to the Transfer Pit. Moved to the Weld Pit, switched to Climax shield plug, installed in Lag Storage Pit \#24.

$08 / 17 / 82$

Moved to the Transfer Pit, loaded into the Surface Transport Vehicle.

$08 / 18 / 82$

Released for transport to Climax. Transported to Climax and emplaced in location \#11. 
FUEL ASSEMBLY D22

FISCAL YEAR 1983

DATE

$03 / 08 / 83$

Recelved the STV. Transferred the canister to the Survey Pit and swiped the exterior of the canister. Transferred the canister to the transfer pit.

$03 / 09 / 83$

Transferred the canister to the Weld Pit. Removed the Climax shield plug. Performed a helium leak check. Obtained gas samples from the canister atmosphere. Performed a second canister leak check. Installed a lag storage shield plug. Transferred the canister to lag storage location 18.

FISCAL YEAR 1984

$12 / 14 / 83$

Transferred the canister from lag storage location 18 to the Weld Pit. Removed the shield plug. Performed a helium leak check on the canister. Collected gas samples from the canister atmosphere. Performed a second leak check. Installed a drywell shield plug. Transferred the canister to the Survey Pit and obtained surface contamination swipes from the exterior of the canister. Transferred the canister to the Transfer Pit.

\section{$12 / 15 / 83$}

Transferred the canister to drywell 5 using the EIV shield. Locomotive L- 5 used as prime mover. The drywell instrumentation was installed and checked out. Thermal monftoring of the canister, liner, and surrounding soil initiated.

\section{$7 / 25 / 84$}

Transferred the canister from drywell 5 to the Transfer Pit using the EIV shield. Locomotive L-5 used as the prime mover. Transferred the canister to the Weld Pit. Removed the shield plug. Performed a helium leak check on the canister. Collected gas samples from the canister atmosphere. Performed a second leak check. Installed the canister shield plug. Transferred the canister back to the Transfer Pit. Transferred the canister back to drywell 5 using the EIV shield. The drywell instrumentation was installed and thermal monitoring of the canister, liner, and surrounding soil continued.

FISCAL YEAR 1985

DATE

$10 / 24 / 84$

Canister transferred from drywell 5 to the Transfer Pit and on to LSP 6 . 
FUEL ASSEMBLY D22

DATE

$11 / 26 / 84$

Transferred the canister from lag storage location 6 to the Weld Pit. Removed the shield plug and performed a helium leak check. Installed the gas sampling plenum and took gas samples of the canister atmosphere. Performed a helium leak check on the canister. Installed the shield plug and transferred the canister back to lag storage location 6 .

\section{$2 / 25 / 85$}

Transferred the canister from lag storage location 6 to the Weld Pit. Removed the shield plug and performed a helium leak check. Installed the gas sampling plenum and took gas samples of the canister atmosphere. Performed a full volume filtration of the atmosphere of the canister through a 0.45 micron filter and then vented to atmosphere. Installed the shield plug and transferred the canister to the Canister Cutter. Cut the canister open. Removed the fuel assembly using the calorimeter grapple. Videotaped the 4 sides of the fuel assembly. Placed the fuel assembly back into the cut canister in the Canister Cutter and placed a cover over the fuel assembly upper nozzle.

\section{$2 / 26 / 85$}

Removed the cover from over the fuel and removed the fuel assembly from the cut canister using the calorimeter grapple. Transferred the fuel to the window $\mathrm{E}-2$ inspection location. Inspected and photographed the fuel. Transferred the fuel to the Survey Pit. Took contamination characterization and integrity monitoring swipes from designated fuel rods. Transferred the fuel to the window E-2 inspection location. Photographed designated areas that had been swiped. Transferred the fuel assembly to an empty canister in the Weld Pit and installed a temporary canister 1id. During installation of the shield plug, 2 support pins could not be fully installed. Removed the shield plug, canister 1 id, and thread protector. Reinstalled the lid and attempted to install the shield plug. Again, the pins could not be installed. Removed the plug (Lag Storage Pit type) and installed a drywell type plug. It was successfully installed. Transferred the canister to lag storage location 6 .

$7 / 10 / 85$

Transferred the canister from lag storage location 6 to the Weld P1t. Removed the shield plug and temporary canister lid. Fuel assembly engaged using the calorimeter grapple and transferred to the Survey PIt. The 16 integrity monitoring swipe samples taken. The fuel assembly was transferred back to the canister in the Weld Pit. The temporary canister lid and shield plug were reinstalled and the canister transferred back to lag storage location 6 .

\section{$8 / 28 / 85$}

Transferred the canister from lag storage location 6 to the Weld Pit. Removed the shield plug and temporary canister lid. Fuel assembly engaged using the calorimeter grapple and transferred to the calorimeter. Initiated thermal stabilization of the system. 
FUEL ASSEMBLY D22

DATE

$8 / 29 / 85$

The decay heat rate of the fuel assembly was measured at $0.451 \mathrm{~kW}$. The fuel was removed from the calorimeter and transferred to the canister in the Weld Pit. Installed a temporary canister lid and shield plug.

Transferred the canister to lag storage location 6 .

FISCAL YEAR 1986

$5 / 86$

Removed the fuel assembly from the canister, performed visual inspection, and loaded assembly in shipping cask for motor transportation to INEL. 
HANDLING HISTORY OF FUEL ASSEMBLY D34

$\begin{array}{ll}\text { Fuel Serial Number: } & \text { D34/LMO 14T } \\ \text { Date Irradiation Started: } & 12 / 12 / 74 \\ \text { Date Irradiation Ended: } & 11 / 19 / 77 \\ \text { Burnup: } & 27,863 \mathrm{MWD} / \mathrm{MTU} \\ \text { Received at EMAD: } & 11 / 01 / 79 \\ \text { By Shipping Cask: } & \text { NLI } 1 / 2\end{array}$

DATE

$11 / 01 / 79$

Shipping cask recelved, fuel assembly transferred to a canister in the Weld Pit, threaded lid installed, and canister transferred to lag storage location \#15.

$01 / 22 / 80$

Moved to the Weld Pit, checked the locations of the canister thermocouple channels, and transferred back to lag storage location \#15.

$02 / 12 / 80$

Moved to the Weld Pit, switched to Climax shield plug, checked alignment of canister $\mathrm{T} / \mathrm{C}$ channels by insertion of wires, reinstalled lag storage shield plug, and transferred back to lag storage location \#15.

$04 / 01 / 80$

Moved to the Weld Pit, obtained gas sample from the unwelded canister, and placed the fuel assembly in the calorimeter. Performed calorimetry ( 1.550 $\mathrm{kW}$ ), transferred to a canister in the Weld Pit, installed the canister lid, and performed seal weld.

$04 / 02 / 80$

Backfilled with helium. Leak checked the canister and placed the canister in lag storage location \#15.

$04 / 24 / 80$

Moved to Weld Pit, switched to Climax shield plug and loaded into Surface Transport Vehicle.

$04 / 25 / 80$

Released for transport to Climax. Transported to Climax and emplaced in location 非. 
FUEL ASSEMBLY D34

FISCAL YEAR 1983

DATE

$03 / 04 / 83$

Received the STV. Transferred the canister to the Survey Pit and swiped the exterior of the canister. Transferred the canister to the transfer pit.

$03 / 07 / 83$

Transferred the canister to the Weld Pit. Removed the Climax shield plug. Performed a helium leak check. Obtained gas samples from the canister atmosphere. Performed a second canister leak check. Installed a lag storage shield plug. Transferred the canister to lag storage location 19.

FISCAL YEAR 1984

$3 / 26 / 84$

Transferred the canister from lag storage location 19 to the Weld Pit. Removed the shield plug. Performed a helium leak check on the canister. Collected gas and full volume filtration samples from the canister atmosphere. Installed the canister shield plug. Transferred the canister to the canister cutter. The canister was cut open. The fuel assembly was grappled using the calorimeter grapple and the 4 sides of the fuel assembly were videotaped. The fuel was placed into a canister in the Weld Pit and 2 temporary canister lid installed.

\section{$3 / 27 / 84$}

The temporary canister lid was removed and the fuel assembly was engaged using the calorimeter grapple. Visual examination and photodocumentation was performed at window E-2. The fuel assembly was transferred to the Sur ey Pit where integrity monitoring and contamination characterization swipes were taken on designated fuel rod surfaces. The fuel assembly was transferred to window E-2. Post-swipe photos were taken, then the fuel was transferred to the Weld pit. The temperature rise of 2 thermoluminescent dosimeters (TLDs) in contact witb the fuel were measured. The fuel was lowered into the canister in the Weld Pit. The grapple was disengaged and a temporary lid installed on the canister.

\section{$3 / 28 / 84$}

The temporary canister lid was removed and the fuel assembly was engaged using the calorimeter grapple. The fuel assembly was transferred to window E-2 for installation of a measuring scale. The fuel was then transferred to the Survey Pit. Radiation levels at contact with the fuel was measured using TLDs. The fuel was returned to the canister in the Weld Pit. The grapple was disengaged and a temporary lid installed on the canister. 
FUEL ASSEMBLY D34

DATE

$3 / 29 / 84$

The temporary canister lid was removed and the fuel assembly was engaged using the calorimeter grapple. The fuel assembly was placed into the calorimeter vessel. The decay heat rate of the fuel assembly was measured at $0.467 \mathrm{~kW}$ using boiling water calorimetry. The data was suspect and later shown to be invalid. The fuel was removed from the calorimeter and returned to the canister in the Weld Pit. The grapple was disengaged and a temporary lid installed on the canister. The shield plug was installed and the canister was transferred to lag storage location 19.

$8 / 17 / 84$

Transferred the canister from lag storage location 19 to the Weld Pit. Removed the shield plug and temporary canister lid. Engaged the fuel assembly with the calorimeter grapple and transferred the fuel to the survey pit. Obtained integrity monitoring swipes from designated fuel rod surfaces. Transferred the fuel back to the canister in the Weld Pit and disengaged the grapple. Installed the temporary lid and the shield plug. Transferred the canister back to lag storage location 19.

FISCAL YEAR 1985

FUEL ASSEMBLY D34

DATE

$12 / 17 / 84$

Transferred the canister from lag storage location 19 to the Weld Pit. Removed the shield plug and temporary canister lid. Fuel assembly engaged using the PWR Fuel Handling Tool and transferred to the Survey Pit. The 16 integrity monitoring swipe samples taken. The fuel assembly was transferred back to the canister in the Weld Pit. The temporary canister lid and shield plug were reinstalled and the canister transferred back to lag storage location 19.

$7 / 11 / 85$

Transferred the canister from lag storage location 19 to the Weld Pit. Removed the shield plug and temporary canister lid. Fuel assembly engaged using the calorimeter grapple and transferred to the Survey Pit. The 16 integrity monitoring swipe samples taken. The fuel assembly was transferred back to the canister in the Weld Pit. The temporary canister lid and shield plug were reinstalled and the canister transferred back to lag storage location 19.

$8 / 20 / 85$

Transferred the canister from lag storage location 19 to the Weld Pit. Removed the shield plug and temporary canister lid. Fuel assembly engaged using the calorimeter grapple and transferred to the calorimeter. Initiated thermal stabilization of the system. 
FUEL ASSEMBLY D34

DATE

$8 / 21 / 85$

The decay heat rate of the fuel assembly was measured at $0.479 \mathrm{~kW}$. The fuel was removed from the calorimeter and transferred to the canister in the Weld Pit. Installed a temporary canister lid and shield plug.

Transferred the canister to lag storage location 19.

FISCAL YEAR 1986

$5 / 86$

Removed the fuel assembly from the canister, performed visual inspection, and loaded assembly in shipping cask for motor transportation to INEL. 
HANDLING HISTORY OF FUEL ASSEMBLY D35

$\begin{array}{ll}\text { Fue } 1 \text { Serial Number: } & \text { D35/LMO 14Q } \\ \text { Date Irradiation Started: } & 12 / 12 / 74 \\ \text { Date Irradiation Ended: } & 11 / 19 / 77 \\ \text { Burnup: } & 28,430 \mathrm{MWD} / \mathrm{MTU} \\ \text { Received at EMAD: } & 11 / 15 / 79 \\ \text { By Shipping Cask: } & \text { NLI } 1 / 2\end{array}$

DATE

$11 / 15 / 79$

Shipping cask received, fuel assembly transferred to a canister in the Weld Pit, and a lid installed. Canister seal welded, backfilled with helium, leak checked, and transferred to lag storage location \#17.

$01 / 22 / 80$

Moved to the Weld Pit, checked the canister thermocouple channel alignment, and transferred back to lag storage location 17.

$02 / 14 / 80$

Moved to the Weld Pit, checked alignment of canister T/C channels by insertion of wires, reinstalled lag storage shield plug, and returned to lag storage location \#17.

$05 / 05 / 80$

Moved to Weld Pit, switched to Climax shield plug and loaded into Surface Transport Vehicle.

$05 / 06 / 80$

Released for transport to Climax. Transported to Climax and emplaced in location $\# 6$.

FISCAL YEAR 1983

$03 / 17 / 83$

Received the STV. Transferred the canister to the Survey Pit and swiped the exterior of the canister. Transferred the canister to the transfer pit.

$03 / 18 / 83$

Transferred the canister to the Weld Pit. Removed the Climax shield plug. Performed a helium leak check. Obtained gas samples from the canister atmosphere. Performed a second canister leak check. Installed a lag storage shield plug. Transferred the canister to lag storage location 15. 
FUEL ASSEMBLY D35

DATE

$08 / 03 / 83$

Transferred the canister from lag storage location 15 to the Weld Pit. Removed the shield plug. Performed a helium leak check. Obtained gas samples from the canister atmosphere. Performed a second canister leak check. Installed a lag storage shield plug. Transferred the canister to lag storage location 15.

FISCAL YEAR 1984

$1 / 9 / 84$

Transferred the canister from lag storage location 15 to the Weld Pit. Removed the shield plug. Performed a helium leak check on the canister. Collected gas samples from the canister atmosphere. Performed a second leak check. Installed the canister shield plug. Transferred the canister back to lag storage location 15.

$7 / 16 / 84$

Transferred the canister from lag storage location 15 to the Weld Pit. Removed the shield plug. Performed a hellum leak check on the canister.

$7 / 17 / 84$

Collected gas samples from the canister atmosphere. Performed a second leak check. Installed the canister shield plug. Transferred the canister back to lag storage location 15.

FISCAL YEAR 1985

\section{$11 / 28 / 84$}

Transferred the canister from lag storage location 15 to the Weld Pit. Removed the shield plug and performed a hellum leak check. Installed the gas sampling plenum and took gas samples of the canister atmosphere. Performed a helium leak check on the canister. Installed the shield plug and transferred the canister back to lag storage location 15.

$6 / 12 / 85$

Transferred the canister from lag storage location 15 to the Weld Pit. Removed the shield plug and performed a helium leak check. Installed the gas sampling plenum and took gas samples of the canister atmosphere. Performed a full volume filtration of the atmosphere of the canister through a 0.45 micron filter and then vented to atmosphere. Installed the shield plug. Transferred the canister to the Canister Cutter. Cut the canister open. Engaged the fuel assembly with the calorimeter grapple and videotaped the 4 sides of the fuel assembly. Returned the fuel assembly into the cut canister in the Canister Cutter. Placed a temporary cover over the upper nozzle of the fuel assembly. 
FUEL ASSEMBLY D35

DATE

$6 / 13 / 85$

Removed the cover from over the fuel assembly. Engaged the fuel assembly with the calorimeter grapple and transported the assembly to the inspection station at window E-2. Obtained a photomosaic of the 0 degree face of the assembly. Performed a visual inspection of the assembly. Obtained photographs of the areas to be swiped. Transferred the assembly to the Survey Pit and obtained characterization and integrity monitoring swipes. Returned the assembly to the inspection station at window $E-2$ and rephotographed the swipe areas. Placed the fuel assembly in the temporary storage canister in the Weld Pit. Installed a temporary canister IId and shield plug. Transferred the canister to lag storage location 15.

FISCAL YEAR 1986

$5 / 86$

Removed the fuel assembly from the canister, performed visual inspection, and loaded assembly in shipping cask for motor transportation to INEL. 


\author{
Fuel Serial Number: D40/LMO $14 \mathrm{P}$ \\ Date Irradiation Started: $12 / 12 / 74$ \\ Date Irradiation Ended: $\quad 11 / 19 / 77$ \\ Burnup: $\quad 28,430 \mathrm{MWD} / \mathrm{MTU}$ \\ Received at EMAD: $\quad 09 / 21 / 79$
}

By Shipping Cask: NLI $1 / 2$

DATE

$09 / 21 / 79$

Shipping cask received, fuel assembly transferred to a canister in the Weld Pit, and a lid installed. Canister seal welded, backfilled with helium, leak checked, and transferred to lag storage location \#9.

$01 / 21 / 80$

Moved to the Weld Pit. Checked the locations of the canister thermocouple channels, transferred back to lag storage location $\$$.

$02 / 11 / 79$

Moved to the Weld Pit, removed the lag storage shield plug and installed a Climax plug. Checked alignment of canister T/C channels using wire, switched back to lag storage plug and returned to lag storage location \#9.

$04 / 14 / 80$

Moved to Weld Pit, switched to Climax shield plug and loaded into Surface Transport Vehicle.

$04 / 15 / 80$

Released for transport to Climax. Transported to Climax and emplaced in location \#1.

FISCAL YEAR 1983

$03 / 11 / 83$

Received the STV. Transferred the canister to the Survey Pit and swiped the exterior of the canister. Transferred the canister to the transfer pit.

$03 / 14 / 83$

Transferred the canister to the Weld Pit. Removed the Climax shield plug. Performed a helium leak check. Obtained gas samples from the canister atmosphere. Performed a second canister leak check. Installed a lag storage shield plug. Transferred the canister to lag storage location 17. 
FUEL ASSEMBLY D40

DATE

$08 / 04 / 83$

Transferred the canister from lag storage location 17 to the Weld Pit. Removed the shield plug. Performed a helium leak check. Obtained gas samples from the canister atmosphere. Performed a second canister leak check. Installed a lag storage shield plug. Transferred the canister to lag storage location 17 .

FISCAL YEAR 1984

$1 / 10 / 84$

Transferred the canister from lag storage location 17 to the Weld Pit. Removed the shield plug. Performed a helium leak check on the canister. Collected gas samples from the canister atmosphere. Performed a second leak check. Installed the canister shield plug. Transferred the canister back to lag storage location 17.

$7 / 17 / 84$

Transferred the canister from lag storage location 17 to the Weld Pit. Removed the shield plug. Performed a helium leak check on the canister. Collected gas samples from the canister atmosphere. Performed a second leak check. Installed the canister shield plug. Transferred the canister back to lag storage location 17.

FISCAL YEAR 1985

\section{$11 / 28 / 84$}

Transferred the canister from lag storage location 17 to the Weld Pit. Removed the shield plug and performed a helium leak check. Installed the gas sampling plenum and took gas samples of the canister atmosphere.

$11 / 29 / 84$

Performed a helium leak check on the canister. Installed the shield plug and transferred the canister back to lag storage location 17.

$7 / 17 / 85$

Transferred the canister from lag storage location 17 to the Weld Pit. Removed the shield plug and performed a helium leak check. Installed the gas sampling plenum and took gas samples of the canister atmosphere. Performed a full volume filtration of the atmosphere of the canister through a 0.45 micron filter and then vented to atmosphere. Installed the shield plug. Transferred the canister to the Canister Cutter. Cut the canister open. Engaged the fuel assembly with the calorimeter grapple and videotaped the 4 sides of the fuel assembly. Returned the fuel assembly into the cut canister in the Canister Cutter. Placed a temporary cover over the upper nozzle of the fuel assembly. 
FUEL ASSEMBLY D40

DATE

$7 / 18 / 85$

Removed the cover from over the fuel assembly. Engaged the fuel assembly with the calorimeter grapple and transported the assembly to the inspection station at window E-2. Obtained a photomosaic of the 0 degree $f$ ace of the assembly. Performed a visual inspection of the assembly. Obtained photographs of the areas to be swiped. Transferred the assembly to the Survey PIt and obtained characterization and integrity monitoring swipes. Returned the assembly to the inspection station at window E-2 and rephotographed the swipe areas. Placed the fuel assembly in the temporary storage canister in the Weld Pit. Investigated the nature of a foreign object on the fuel by taking one photograph and touching it with a steel probe. Installed a temporary canister lid and shield plug. Transferred the canister to lag storage location 17.

FISCAL YEAR 1986

$10 / 17 / 85$

Transferred the canister from lag storage location 17 to the weld pit. Removed the shield plug and temporary canister lid. Engaged the fuel assembly with the calorimeter grapple and raised the fuel assembly partially out of the canister. Removed foreign object from on top of the fuel rods with a vacuum nozzle. Returned the fuel assembly into the canister. Installed the canister lid and shield plug. Transferred the canister back to lag storage location 17.

\section{$5 / 86$}

Removed the fuel assembly from the canister, performed visual inspection, and loaded assembly in shipping cask for motor transportation to INEL. 
Fuel Serial Number:

Date Irradiation Started:

Date Irradiation Ended:

Burnup :

Received at EMAD:

By Shipping Cask:
D46/LMO 151

$12 / 12 / 74$

$11 / 19 / 77$

$28,430 \mathrm{MWD} / \mathrm{MTU}$

$09 / 24 / 79$

NLI $1 / 2$

DATE

$09 / 25 / 79$

Shipping cask received, fuel assembly transferred to a canister in the Weld P1t, and a lid Installed. Canister seal welded, shield plug installed, and transferred to lag storage location \#10.

$09 / 27 / 79$

Transferred to the Weld Pit, shield plug removed, backfilled with hellum, and leak checked. Shleld plug relnstalled and transferred to lag storage location \#10.

$01 / 21 / 80$

Moved to the Weld Pit, checked location of canister thermocouple channels wth fixture, placed back in lag storage location \#10.

$02 / 12 / 80$

Moved to the Weld Pit, removed lag storage shield plug and installed Climax shield plug. Checked allgnment of canister T/C channels by wire insertion, switched back to lag storage plug and returned to lag storage location \#10.

$04 / 28 / 80$

Moved to Weld Pit, switched to Climax shleld plug and loaded into Surface Transport Vehicle.

$04 / 29 / 80$

Released for transport to Climax. Transported to Climax and emplaced in location 非.

FISCAL YEAR 1983

$03 / 15 / 83$

Recelved the STV. Transferred the canister to the Survey P1t and swiped the exterior of the canister. Transferred the canister to the transfer pit. 
FUEL ASSEMBLY D46

DATE

$03 / 16 / 83$

Transferred the canister to the Weld Pit. Removed the Climax shield plug. Performed a helium leak check. Obtained gas samples from the canister atmosphere. Performed a second canister leak check. Installed a lag storage shield plug. Transferred the canister to lag storage location 16.

FISCAL YEAR 1984

$1 / 10 / 84$

Transferred the canister from lag storage location 16 to the Weld Pit. Removed the shield plug. Performed a helium leak check on the canister. Collected gas samples from the canister atmosphere. Performed a second leak check. Installed the canister shield plug. Transferred the canister back to lag storage location 16 .

\section{$7 / 17 / 84$}

Transferred the canister from lag storage location 16 to the Weld Pit. Removed the shield plug. Performed a helium leak check on the canister.

\section{$7 / 18 / 84$}

Collected gas samples from the canister atmosphere. Performed a second leak check. Installed the canister shield plug. Transferred the canister back to lag storage location 16 .

FISCAL YEAR 1985

$11 / 29 / 84$

Transferred the canister from lag storage location 16 to the Weld Pit. Removed the shield plug and performed a helium leak check. Installed the gas sampling plenum and took gas samples of the canister atmosphere. Performed a helium leak check on the canister. Installed the shield plug and transferred the canister back to lag storage location 16.

$7 / 29 / 85$

Transferred the canister from lag storage location 16 to the Weld Pit. Removed the shield plug and performed a helium leak check. Installed the gas sampling plenum and took gas samples of the canister atmosphere. Performed a full volume filtration of the atmosphere of the canister through a 0.45 micron filter and then vented to atmosphere. Installed the shield plug. Transferred the canister back to lag storage location 16. 
FUEL ASSEMBLY D46

DATE

$7 / 31 / 85$

Transferred the canister from lag storage location 16 to the Canister Cutter. Cut the canister open. Engaged the fuel assembly with the calorimeter grapple and videotaped the 4 sides of the fuel assembly.

Returned the fuel assembly into the cut canister in the Canister Cutter.

Placed a temporary cover over the upper nozzle of the fuel assembly.

$8 / 1 / 85$

Removed the cover from over the fuel assembly. Engaged the fuel assembly with the calorimeter grapple and transported the assembly to the inspection station at window E-2. Obtalned a photomosalc of the 0 degree face of the assembly. Performed a visual inspection of the assembly. Obtained photographs of the areas to be swiped. Transferred the assembly to the Survey Pit and obtained characterization and integrity monitoring swipes. Returned the assembly to the inspection station at window $\mathrm{E}-2$ and rephotographed the swipe areas. Placed the fuel assembly in the temporary storage canister in the Weld Pit. Installed a temporary canister lid and shield plug. Transferred the canister to lag storage location 16.

FISCAL YEAR 1986

$5 / 86$

Removed the fuel assembly from the canister, performed visual inspection, and loaded assembly in shipping cask for motor transportation to INEL. 
Fuel Serial Number:

Date Irradiation Started:

Date Irradiation Ended:

Burnup :

Received at EMAD:

By Shipping Cask:

\author{
D47/LMO 14Y \\ $12 / 12 / 74$ \\ $11 / 19 / 77$ \\ 28,430 MWD/MTU \\ $10 / 01 / 79$
}

NLI $1 / 2$

DATE

10/01/79

Shipping cask recelved, fuel assembly transferred to a canister in the Weld P1t, and a lid installed. Canister seal welded, backfilled with helium, leak checked and transferred to lag storage location $\|_{11}$.

$01 / 21 / 79$

Moved to the Weld Pit, alignment of thermocouple channels on canister checked with fixture. Returned to lag storage pit \#11.

$02 / 13 / 80$

Moved to the Weld Pit, installed Climax shield plug. Checked alignment of canister T/C channels by wire insertion. Loaded the canister into the STV. Performed a radiation survey on the STV and Hot Bay. Fuel transferred to the transfer pit. STV released. Fuel transferred to the Weld Pit, lag storage shield plug replaced and canister returned to lag storage location \#1.

$05 / 07 / 80$

Moved to Weld Pit, switched to Climax shleld plug and loaded into Surface Transport Vehicle.

$05 / 08 / 80$

Released for transport to Climax. Transported to Climax and emplaced in location $\$$;.

FISCAL YEAR 1983

$03 / 25 / 83$

Received the STV. Transferred the canister to the Survey Pit and swiped the exterior of the canister. Transferred the canister to the transfer pit. 
FUEL ASSEMBLY D47

DATE

$03 / 28 / 83$

Transferred the canister to the Weld Pit. Removed the Climax shield plug. Performed a hellum leak check. Obtained gas samples from the canister atmosphere. Performed a second canister leak check. Installed a lag storage shield plug. Transferred the canister to lag storage location 13.

FISCAL YEAR 1984

$1 / 11 / 84$

Transferred the canister from lag storage location 13 to the Weld Pit. Removed the shield plug. Performed a hellum leak check on the canister. Collected gas samples from the canister atmosphere. Performed a second leak check. Installed the canister shield plug. Transferred the canister back to lag storage location 13.

$7 / 18 / 84$

Transferred the canister from lag storage location 13 to the Weld Pit. Removed the shield plug. Performed a helium leak check on the canister. Collected gas samples from the canister atmosphere. Performed a second leak check. Installed the canister shield plug. Transferred the canister back to lag storage location 13.

FISCAL YEAR 1985

\section{$11 / 29 / 84$}

Transferred the canister from lag storage location 13 to the Weld Pit. Removed the shield plug and performed a helium leak check. Installed the gas sampling plenum and took gas samples of the canister atmosphere.

$11 / 30 / 84$

Performed a hellum leak check on the canister. Installed the shield plug and transferred the canister back to lag storage location 13.

$7 / 29 / 85$

Transferred the canister from lag storage location 13 to the Weld Pit. Removed the shield plug and performed a helium leak check.

$7 / 30 / 85$

Installed the gas sampling plenum and took gas samples of the canister atmosphere. Performed a full volume filtration of the atmosphere of the canister through a 0.45 micron filter and then vented to atmosphere. Installed the shield plug. Transferred the canister back to lag storage location 13. 
FUEL ASSEMBLY D47

DATE

$8 / 2 / 85$

Transferred the canister from lag storage location 13 to the Canister Cutter. Cut the canister open. Engaged the fuel assembly with the calorimeter grapple and videotaped the 4 sides of the fuel assembly. Returned the fuel assembly into the cut canister in the Canister Cutter. Placed a temporary cover over the upper nozzle of the fuel assembly.

$8 / 5 / 85$

Removed the cover from over the fuel assembly. Engaged the fuel assembly with the calorimeter grapple and transported the assembly to the inspection station at window E-2. Obtained a photomosaic of the 0 degree face of the assembly. Performed a visual inspection of the assembly. Obtained photographs of the areas to be swiped. Transferred the assembly to the Survey Pit and obtained characterization and integrity monitoring swipes. Returned the assembly to the inspection station at window $\mathrm{E}-2$ and rephotographed the swipe areas. Placed the fuel assembly in the temporary storage canister in the Weld Pit. Installed a temporary canister lid and shield plug. Transferred the canister to lag storage location 13.

FISCAL YEAR 1986

$5 / 86$

Removed the fuel assembly from the canister, performed visual inspection, and loaded assembly in shipping cask for motor transportation to INEL. 
APPENDIX R

DECAY HEAT MEASUREMENTS 


\section{'}

-

.

. 


\section{DECAY HEAT MEASUREMENTS}

Decay heat rates were measured for fuel assemblies B43, D03, D15, D22 and D34 using a hoiling water calorimeter hoth hefore testing and after storage. The results of these measurements are listed in Table B.I and compared with the predicted decay heat generation in Figures B.1, B.2, B.3, and B.4. The preand post-test analyses of the water for contamination are summarized in Table B.2.

TABLE R.1. Results of Decay Heat Calorimeter Tests

Fuel

Serial

B43

004

$\mathrm{D} 15$

D22

1)34

$\frac{\text { Date }}{9 / 10 / 80}$
$8 / 23 / 85$

$5 / 20 / 80$

$8 / 28 / 85$

$7 / 08 / 80$

$1 / 06 / 81$

$8 / 22 / 85$

$7 / 09 / 80$

$8 / 29 / 85$

$4 / 01 / 80$

$8 / 21 / 85$
Decay Heat (kW)

$$
0.637
$$

0.392

$$
1.385(\mathrm{a})
$$

0.487

1.423

1.126

0.506

1.284

0.451

1.550

0.479

(a) Possible error noted. 
TABLE B.2. Analysis of Calorimeter Water for Contamination (1985)

\begin{tabular}{|c|c|c|c|c|c|}
\hline $\begin{array}{l}\text { Fuel } \\
\text { Serial }\end{array}$ & Element & $\begin{array}{c}\text { Soluble } \mathrm{F} \\
\text { Pre } \\
\end{array}$ & $\frac{\text { rtion, }, 1 \mathrm{Ci}}{\text { Post }}$ & $\frac{\text { Insoluble } \mathrm{P}}{\mathrm{Pre}}$ & $\frac{\text { Portion, }{ }_{11} \mathrm{C}}{\text { Post }}$ \\
\hline \multirow[t]{2}{*}{ B43 } & Cs & 0.000201 & 0.000212 & - & - \\
\hline & Co & 0.000128 & 0.000010 & 0.0737 & 0.0492 \\
\hline \multirow[t]{2}{*}{ D04 } & Cs & 0.000212 & 0.000299 & - & - \\
\hline & Co & 0.000010 & 0.000013 & 0.0492 & 0.0503 \\
\hline \multirow[t]{2}{*}{ D15 } & Cs & 0.000091 & 0.000201 & - & - \\
\hline & Co & - & 0.000128 & 0.0227 & 0.0737 \\
\hline \multirow[t]{2}{*}{ D22 } & Cs & 0.000299 & 0.000491 & - & - \\
\hline & Co & 0.000013 & 0.000046 & 0.0503 & 0.0550 \\
\hline \multirow[t]{2}{*}{ D34 } & Cs & 0.000042 & 0.000091 & 0.00000682 & - \\
\hline & Co & 0.000013 & - & 0.00000080 & 0.0227 \\
\hline
\end{tabular}




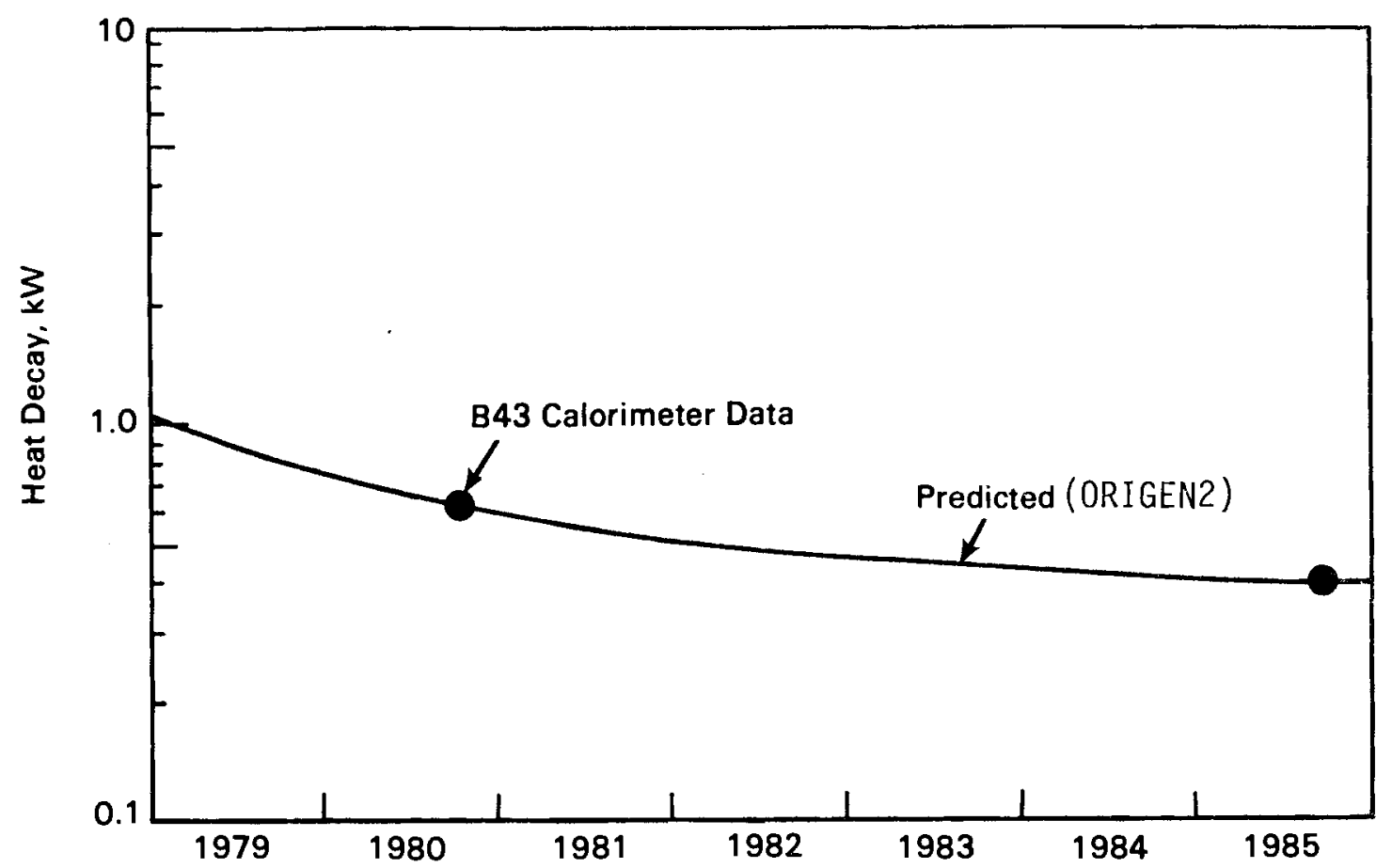

FIGURE B.1. Decay Heat Curve for Fuel Assemblies B02, B03, B41, and B43

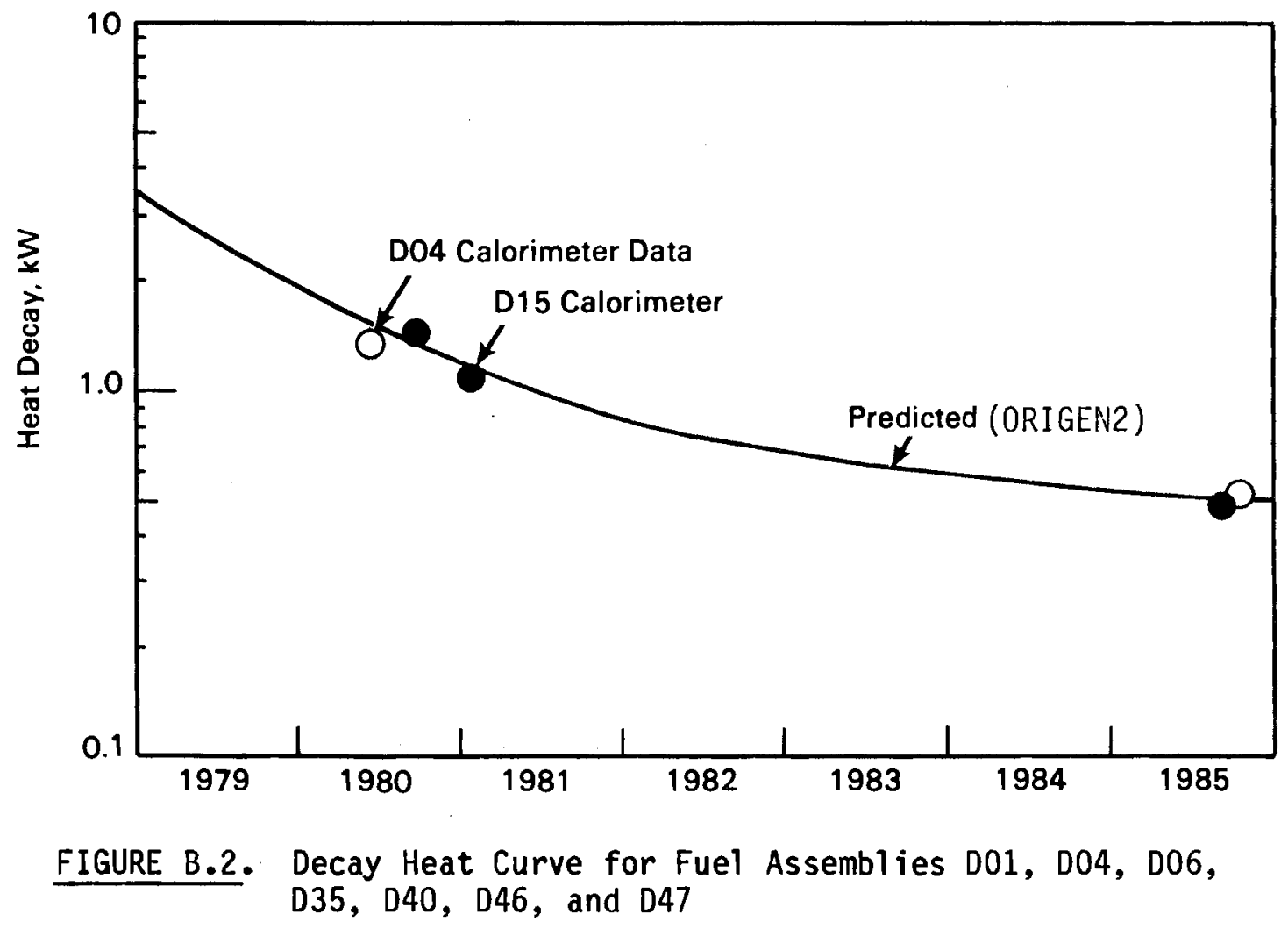

B.3 


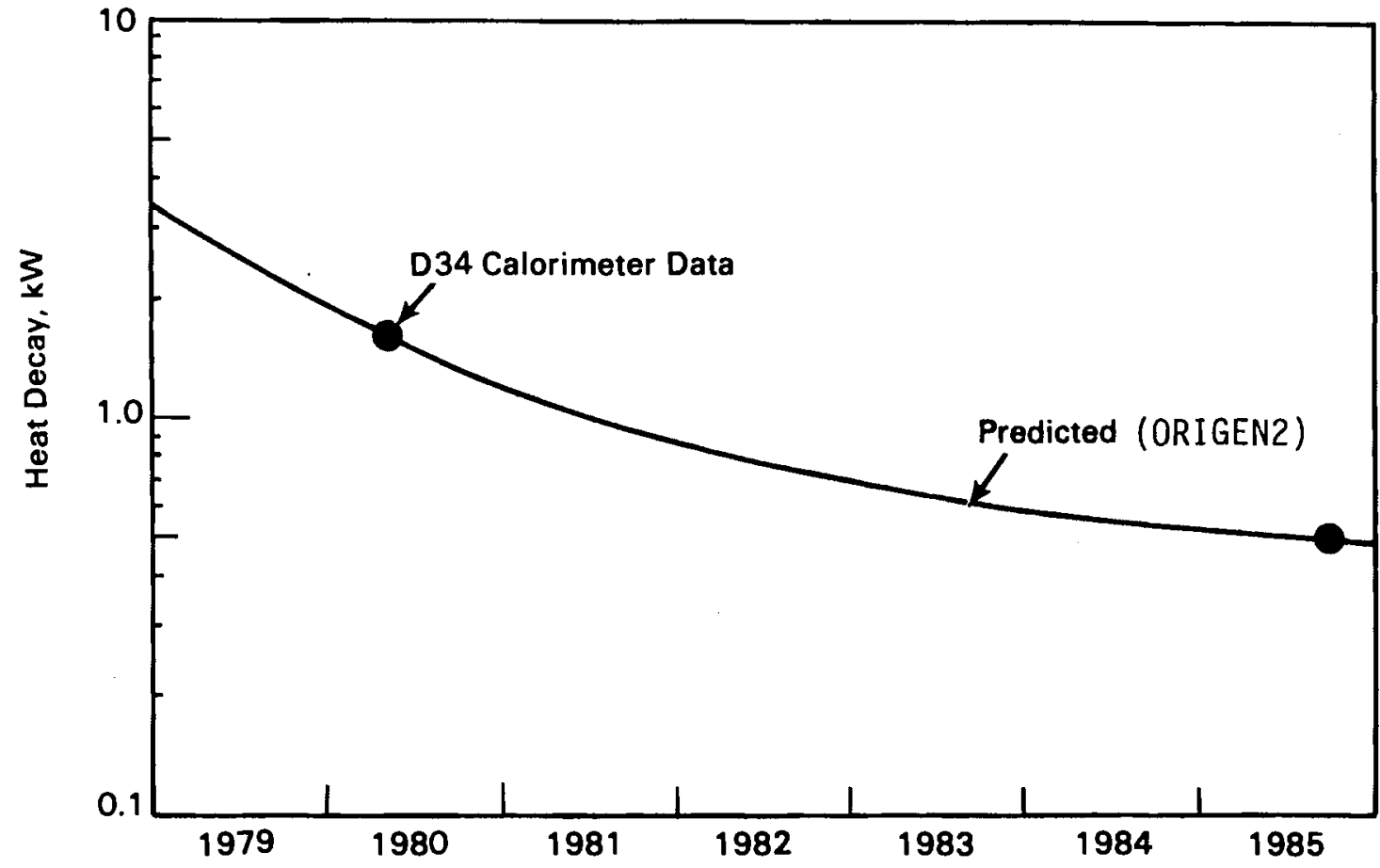

FIGURE B.3. Decay Heat Curve for Fuel Assemblies D09, D16, D18, and D34

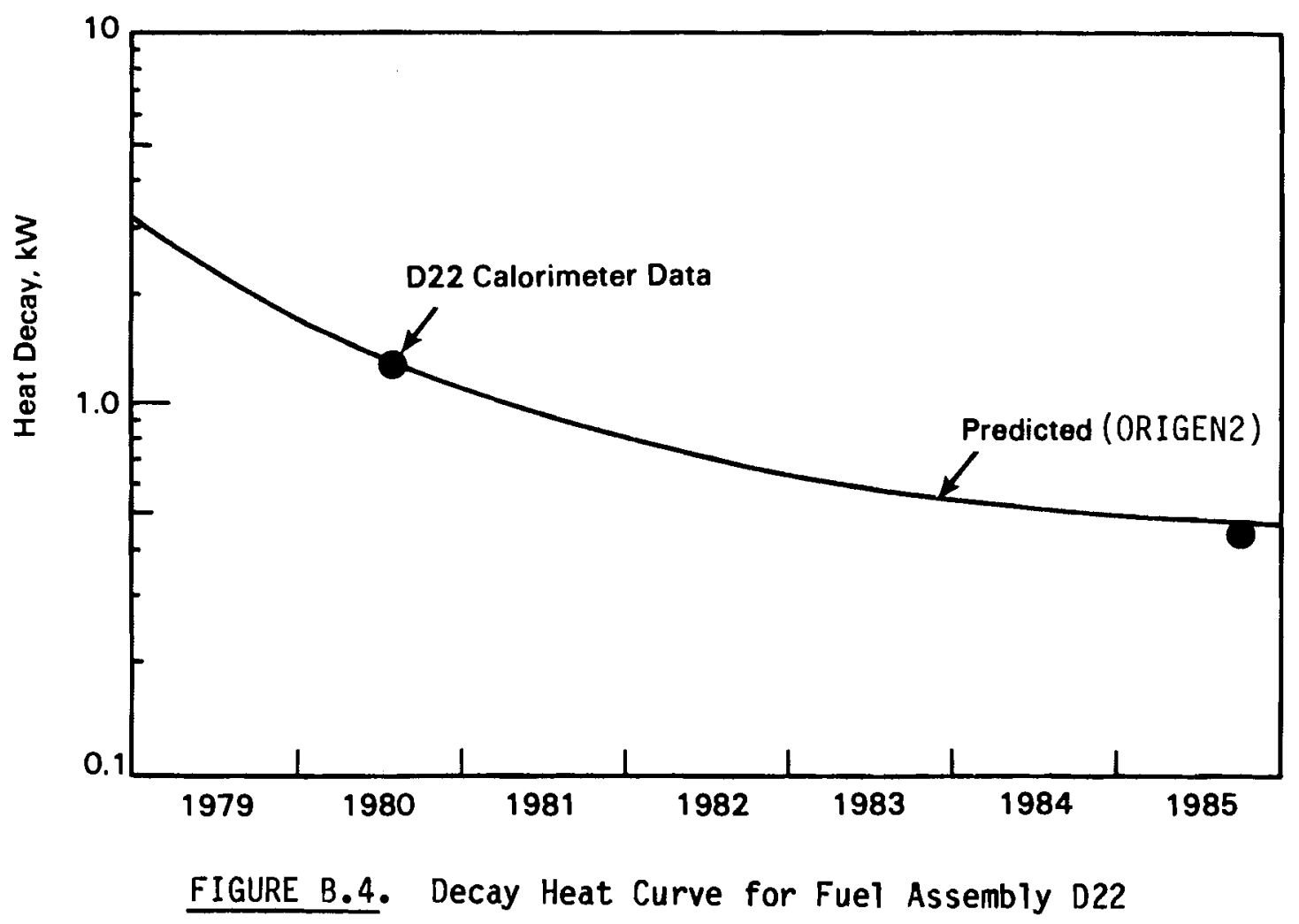


APPENDIX C

PREDICTION OF PEAK FUEL CLAI TEMPERATURES FROM

MEASURED CANISTER TEMPERATURES 


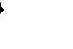


The relationship between the canister temperatures measured in dry storage demonstration tests and the peak fuel cladding temperature was developed from data obtained from the FAITM test during the period between 1979 and 1981 by the procedure documented by Unterzuber (1982).

The relationship between canister temperature and peak fuel clad temperature used for helium filled canisters was as follows:

$$
\mathrm{T}_{\text {peak }}=\mathrm{T}_{\text {can }}+\mathrm{Q}\left(243.26-0.6752 \mathrm{~T}_{\mathrm{can}}+0.0006677\left(\mathrm{~T}_{\mathrm{can}}\right)^{2}\right)
$$

where $T_{\text {peak }}=$ peak fuel clad temperature, ${ }^{\circ} \mathrm{F}$

$\mathrm{T}_{\text {can }}=$ canister temperature, ${ }^{\circ} \mathrm{F}$

$Q=$ fuel assembly decay heat level, $\mathrm{kW}$

This equation was used to predict peak fuel clad temperatures for fuel assemblies B03, B41, B43, B43, D09, D16, and D22 while stored in the EMAD and SFT-C drywells.

The relationship between canister temperature and peak fuel clad temperature for air-filled canisters was as follows:

$$
T_{\text {peak }}=T_{\text {can }}+Q\left(298.86-0.7157 T_{\text {can }}+0.0006697\left(T_{\text {can }}\right)^{2}\right)
$$

This equation was used to predict fuel clad temperatures in the FTT tests on B02 and for fuel assembly D06 while stored in an unwelded canister in the lag storage pit.

The maximum errors in the peak clad temperatures predicted by the above equations are $-5^{\circ} \mathrm{F}$ to $+12^{\circ} \mathrm{F}$ determined from measurement uncertainties and calculational method inaccuracies. 
$+$

$-\infty$

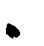




\section{APPENDIX D}

FISSION GAS ANALYSIS RESULTS OBTAINED

BY DRILLING SELECTED FUEL RODS 


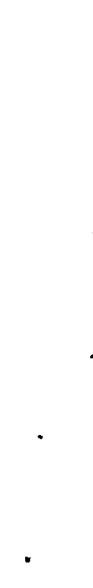


FISSION GAS ANALYSIS RESULTS OBTAINED

BY DRILLING SELECTED FUEL RODS

Ten fuel rods were drilled to collect gas samples for analysis of fission gas pressure and composition. The results are given in Table D.1.

TABLE D.1. Internal Rod Gas Pressure and Analyses

\begin{tabular}{|c|c|c|c|c|c|c|c|c|}
\hline \multirow[b]{2}{*}{ Element/Rod } & Temperature, & $\begin{array}{c}\text { Gas } \\
\text { Pressure, }\end{array}$ & \multicolumn{6}{|c|}{ Species, vol\% } \\
\hline & ${ }^{\circ} \mathrm{F}$ & psia & $\mathrm{He}$ & 0 & $N$ & $A$ & $\mathrm{Xe}$ & $\mathrm{Kr}$ \\
\hline $\mathrm{B} 17 / \mathrm{H}(\mathrm{a})$ & 78 & 386 & 98.744 & $<0.01$ & 0.03 & 0.54 & 0.615 & 0.071 \\
\hline$B 17 / \mathrm{J}^{(a)}$ & 77 & 385 & 98.509 & $<0.01$ & 0.03 & 0.84 & 0.540 & 0.061 \\
\hline$B 17 / G 7(a)$ & 78 & 361 & 99.120 & $<0.01$ & 0.04 & 0.17 & 0.586 & 0.064 \\
\hline $\mathrm{B} 17 / \mathrm{Gg}(\mathrm{a})$ & 77 & 401 & 98.633 & $<0.02$ & 0.09 & 0.15 & 0.979 & 0.118 \\
\hline$B 17 / 19(a)$ & 80 & 331 & 96.706 & $<0.01$ & 0.02 & 2.43 & 0.738 & 0.086 \\
\hline$D 01 / G 9$ (b) & 77 & 496 & 99.4 & $<0.01$ & 0.01 & 0.07 & 0.43 & 0.05 \\
\hline$D 01 / G 10^{(b)}$ & 77 & 523 & 99.4 & $<0.01$ & $<0.01$ & 0.13 & 0.45 & 0.05 \\
\hline $\mathrm{D} 01 / \mathrm{Hg}(\mathrm{b})$ & 77 & 514 & 98.7 & $<0.01$ & $<0.01$ & 0.72 & 0.49 & 0.05 \\
\hline D04/G9(b) & 77 & 499 & 98.9 & $<0.01$ & $<0.01$ & 0.58 & 0.44 & 0.05 \\
\hline$D 04 / G 10^{(b)}$ & 77 & 507 & 98.3 & 0.12 & 0.43 & 0.60 & 0.46 & 0.05 \\
\hline
\end{tabular}

(a) R. B. Davis and V. Pasupathi. 1981. Data Summary Report for the NonDestructive Examination of Rds G7, G9, J8, I9, and $\mathrm{H} 6$ from the Turkey Point Fuel Assembly B17. HEDL-TME 80-85, Westinghouse Hanford Co., Richland, Washington.

(b) S. D. Atkins. 1981. Destructive Examination of 3-Cycle LWR Fuel Rods from Turkey Point Unit 3 for the Climax-Spent Fuel Test. HEDL-TME 80-89, Westinghouse Hanford Co., Richland, Washington. 
APPENIIX E

SUMMARY OF CLAD INTEGRITY DATA 


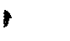

$-$

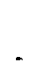

-

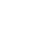

$\checkmark$ 
APPENDIX E

SUMMARY OF CLAD INTEGRITY DATA

Gas samples were periodically removed from the canisters and analyzed by gamma spectrometry. The results are listed in Table E.1. The results from the more frequent monitoring of $\mathrm{BO2}$ canister gas are listed in Table E.2.

Fuel assemblies stored at EMAD in unwelded canisters were checked for surface activity by taking swipes on selected fuel rods. The maximum activities of detected species for each stated data are listed in Table E.3. The canister swipe and residue data are summarized in Table E.4.

TABLE E.1. Summary of Gas Sample Integrity Monitoring Results

\begin{tabular}{|c|c|c|c|c|}
\hline $\begin{array}{c}\text { Fuel } \\
\text { Assembly } \\
\end{array}$ & Sample Data & $\begin{array}{c}\text { Krypt on }-85, \\
\mathrm{pCi} / \mathrm{cc} \\
(\text { Lab 1) } \\
\end{array}$ & $\begin{array}{l}\text { Krypton-85, } \\
\text { pCi/cc } \\
\left(\begin{array}{l}\text { Lab 2) } \\
\end{array}\right.\end{array}$ & $\begin{array}{l}\text { Hel ium, } \\
\text { vol\% } \\
\end{array}$ \\
\hline $\mathrm{BO2}$ & $\begin{array}{c}7 / 13 / 82 \\
10 / 13 / 82\end{array}$ & $\begin{array}{l}<8.8 \\
<0.045\end{array}$ & $\begin{array}{l}0.14 \\
0.08\end{array}$ & $\begin{array}{l}99.3(b) \\
51.8\end{array}$ \\
\hline B03 & $\begin{array}{r}8 / 04 / 80 \\
6 / 23 / 82 \\
8 / 12 / 83 \\
12 / 20 / 83 \\
6 / 15 / 84\end{array}$ & $\begin{array}{l}<6.0 \\
<8.8 \\
<13 \\
<5.6 \\
<10.7\end{array}$ & $\begin{aligned}< & 300 \\
< & 0.01 \\
< & 0.31 \\
& 0.54 \\
& 0.09\end{aligned}$ & $\begin{array}{l}99.1(\mathrm{~b}) \\
0.0 \\
97.5 \\
97.4 \\
97.5\end{array}$ \\
\hline B41 & $\begin{array}{r}8 / 05 / 80 \\
6 / 21 / 82 \\
8 / 11 / 83 \\
12 / 19 / 83 \\
7 / 24 / 84 \\
11 / 19 / 84 \\
11 / 20 / 84 \\
12 / 20 / 84 \\
1 / 16 / 85 \\
2 / 20 / 85 \\
6 / 20 / 85 \\
8 / 08 / 85(a)\end{array}$ & $\begin{aligned} & 1400 \\
< & 8.8 \\
& 2500 \\
& 2430 \\
& 2200 \\
& 1960 \\
< & 11.0 \\
< & 2.4 \\
< & 2.5 \\
< & 4.7 \\
< & 12.0 \\
< & 14\end{aligned}$ & $\begin{aligned} &< 300 \\
&< 0.03 \\
& 2200 \\
& 2052 \\
& 2880 \\
& 1620 \\
& 1620 \\
& 7.0 \\
& 7.0 \\
& 7.0 \\
& 7.0 \\
& 8.05 \\
& 7.88\end{aligned}$ & $\begin{array}{l}99.5 \\
0.0(b) \\
98.0 \\
97.9 \\
97.9 \\
97.4 \\
99.9 \\
99.9 \\
99.9 \\
98.4 \\
99.9 \\
99.9\end{array}$ \\
\hline B43 & $\begin{array}{l}6 / 18 / 82 \\
8 / 10 / 83(a) \\
2 / 14 / 84(a)\end{array}$ & $\begin{aligned} & 8.8 \\
< & 13 \\
< & 6.2\end{aligned}$ & $\begin{array}{l}0.15 \\
0.14 \\
0.15\end{array}$ & $\begin{array}{l}99.6 \\
99.6 \\
99.8\end{array}$ \\
\hline
\end{tabular}


TABLE E.1. (contd)

\begin{tabular}{|c|c|c|c|c|}
\hline $\begin{array}{c}\text { Fuel } \\
\text { Assembly }\end{array}$ & Sample Data & $\begin{array}{c}\text { Krypton }-85, \\
\text { pCi / cc } \\
(\text { Lab 1) } \\
\end{array}$ & $\begin{array}{l}\text { Krypton-85, } \\
\text { pC } i / c C \\
(\text { Lab 2) } \\
\end{array}$ & $\begin{array}{c}\text { Helium, } \\
\text { vol\% } \\
\end{array}$ \\
\hline $\mathrm{D} 01$ & $\begin{array}{l}7 / 06 / 83^{(a)} \\
1 / 04 / 84 \\
5 / 21 / 84(a)\end{array}$ & $\begin{array}{l}<8.0 \\
<5.8 \\
<9.97\end{array}$ & $\begin{array}{l}0.42 \\
0.44 \\
0.42\end{array}$ & $\begin{array}{l}99.2 \\
99.2 \\
99.3\end{array}$ \\
\hline D04 & $\begin{array}{l}4 / 09 / 80 \\
8 / 19 / 82 \\
8 / 02 / 83 \\
1 / 05 / 84 \\
5 / 21 / 84(a)\end{array}$ & $\begin{array}{l}<30 \\
<3.3 \\
<14 \\
<6.2 \\
<12.6\end{array}$ & $\begin{array}{l}<300 \\
0.35 \\
7.9 \\
8.9 \\
8.8\end{array}$ & $\begin{array}{l}\text { Unwelded } \\
1.92(5) \\
93.2 \\
93.0 \\
93.2\end{array}$ \\
\hline D06 & $\begin{array}{l}6 / 25 / 82 \\
6 / 20 / 83(a)\end{array}$ & $\begin{array}{l}<8.8 \\
<4.6\end{array}$ & $\begin{array}{l}0.63 \\
0.41\end{array}$ & $\begin{array}{l}98.1 \\
99.2\end{array}$ \\
\hline D09 & $\begin{array}{c}6 / 29 / 83 \\
1 / 05 / 84 \\
7 / 23 / 84 \\
11 / 26 / 84 \\
3 / 04 / 85(a)\end{array}$ & $\begin{array}{l}<8.3 \\
<6.0 \\
<9.97 \\
<11.0 \\
<6.8\end{array}$ & $\begin{array}{l}0.5 \\
0.5 \\
0.49 \\
0.63 \\
0.62\end{array}$ & $\begin{array}{l}98.6 \\
98.9 \\
98.7 \\
98.5 \\
98.9\end{array}$ \\
\hline D15 & $\begin{array}{l}4 / 10 / 80 \\
3 / 23 / 83 \\
7 / 25 / 83\end{array}$ & $\begin{array}{l}<30 \\
<8 \\
<14\end{array}$ & $\begin{array}{l}<300 \\
4.07 \\
4.2\end{array}$ & $\begin{array}{l}\text { Unwe] ded } \\
87.0(\text { b) } \\
99.1\end{array}$ \\
\hline D16 & $\begin{array}{c}7 / 05 / 83 \\
1 / 06 / 84 \\
5 / 30 / 84 \\
11 / 2786 \\
4 / 28 / 85(a)\end{array}$ & $\begin{array}{l}<7.7 \\
<6.9 \\
<10.3 \\
<11 \\
<14\end{array}$ & $\begin{array}{l}0.15 \\
0.31 \\
0.43 \\
0.44 \\
0.49\end{array}$ & $\begin{array}{l}98.9 \\
99.5 \\
99.3 \\
97.6 \\
99.2\end{array}$ \\
\hline D18 & $\begin{array}{r}6 / 30 / 83 \\
1 / 09 / 83 \\
7 / 16 / 84 \\
11 / 28 / 84 \\
4 / 28 / 84\end{array}$ & $\begin{array}{l}<14 \\
<7.2 \\
<10.3 \\
<11 \\
<14\end{array}$ & $\begin{array}{l}0.38 \\
0.34 \\
0.34 \\
0.37 \\
0.34\end{array}$ & $\begin{array}{l}98.5 \\
99.1 \\
98.5 \\
99.1 \\
99.0\end{array}$ \\
\hline $\mathrm{D} 22$ & $\begin{array}{r}6 / 25 / 80 \\
6 / 28 / 82 \\
3 / 09 / 83 \\
12 / 14 / 83 \\
7 / 25 / 84 \\
11 / 26 / 84 \\
2 / 25 / 85 \\
2 \text { (a) }\end{array}$ & $\begin{array}{l}<6 \\
<8.8 \\
<6 \\
<8.52 \\
<9.65 \\
<11 \\
<12\end{array}$ & $\begin{array}{c}300 \\
8.2 \\
8.4 \\
7.0 \\
7.1 \\
7.2 \\
7.12\end{array}$ & $\begin{array}{l}\text { Unwelded } \\
97.7 \\
98.9 \\
99.6 \\
99.5 \\
99.5 \\
99.5\end{array}$ \\
\hline
\end{tabular}


TABLE E.1. (contd)

\begin{tabular}{|c|c|c|c|c|}
\hline $\begin{array}{c}\text { Fuel } \\
\text { Assembly } \\
\text { As semb }\end{array}$ & Sample Data & $\begin{array}{c}\text { Krypt on }-85, \\
\text { pCi/cc } \\
(\text { Lab 1) } \\
\end{array}$ & $\begin{array}{l}\text { Krypton-85, } \\
\mathrm{pCC} / \mathrm{icc} \\
(\mathrm{Lab} 2) \\
\end{array}$ & $\begin{array}{l}\text { Helium, } \\
\text { vol\% } \\
\end{array}$ \\
\hline D34 & $\begin{array}{l}4 / 01 / 80 \\
3 / 07 / 83 \\
3 / 26 / 84(a)\end{array}$ & $\begin{array}{l}<30 \\
<6 \\
<21.0\end{array}$ & $\begin{aligned}< & 300 \\
< & 0.03 \\
& 4.56\end{aligned}$ & $\begin{array}{l}\text { Unweld ded } \\
0.0(\mathrm{~b}) \\
95.3\end{array}$ \\
\hline D35 & $\begin{array}{c}3 / 17 / 83 \\
8 / 03 / 83 \\
1 / 09 / 84 \\
7 / 17 / 84 \\
11 / 28 / 84 \\
6 / 12 / 85(a)\end{array}$ & $\begin{array}{l}<7 \\
<14 \\
<7.4 \\
<10.7 \\
<11 \\
<15\end{array}$ & $\begin{array}{l}0.07 \\
0.29 \\
1.0 \\
0.30 \\
0.29 \\
0.29\end{array}$ & $\begin{array}{l}24.1(a) \\
98.8 \\
98.9 \\
98.8 \\
98.7 \\
91.9\end{array}$ \\
\hline D40 & $\begin{array}{c}3 / 11 / 83 \\
8 / 04 / 83 \\
1 / 10 / 84 \\
7 / 17 / 84 \\
11 / 29 / 84 \\
7 / 17 / 85 \text { (a) }\end{array}$ & $\begin{array}{l}<6 \\
<13 \\
<7.4 \\
<10.3 \\
<11 \\
<17\end{array}$ & $\begin{array}{l}0.45 \\
0.52 \\
0.48 \\
0.98 \\
0.42 \\
0.89\end{array}$ & $\begin{array}{l}73.8^{(b)} \\
98.7 \\
98.5 \\
98.6 \\
98.7 \\
98.9\end{array}$ \\
\hline D46 & $\begin{array}{c}3 / 15 / 83 \\
1 / 10 / 84 \\
7 / 08 / 84 \\
11 / 29 / 84 \\
7 / 29 / 85 \text { (a) }\end{array}$ & $\begin{array}{l}<6 \\
<7.2 . \\
<11.2 \\
<12 \\
<20\end{array}$ & $\begin{array}{l}0.76 \\
2.7 \\
0.66 \\
0.64 \\
0.73\end{array}$ & $\begin{array}{l}99.0 \\
99.4 \\
99.3 \\
99.0 \\
99.7\end{array}$ \\
\hline D47 & $\begin{array}{c}3 / 25 / 83 \\
1 / 11 / 84 \\
7 / 18 / 84 \\
11 / 30 / 84 \\
7 / 30 / 85\end{array}$ & $\begin{array}{l}<6 \\
<7.7 \\
<11.7 \\
<12 \\
<21\end{array}$ & $\begin{array}{l}3.34 \\
2.9 \\
3.0 \\
2.8 \\
2.99\end{array}$ & $\begin{array}{l}99.4 \\
99.2 \\
99.4 \\
99.4 \\
99.4\end{array}$ \\
\hline
\end{tabular}

(a) Canister cut open.

(b) Air dilution in samples. 
TABLE E.3. Summary of Fuel Swipe Analyses (in mirocuries)

\begin{tabular}{|c|c|c|c|c|c|}
\hline \multicolumn{2}{|c|}{ Fuel Data } & $\begin{array}{l}\text { Maximum } \\
{ }^{60} \mathrm{Co} \\
\end{array}$ & $\begin{array}{c}\text { Maximum } \\
125 \mathrm{Sb} \\
\end{array}$ & $\begin{array}{c}\text { Maximum } \\
\text { Gross Beta }\end{array}$ & Comments/0ther \\
\hline B02 & $\begin{array}{r}10 / 15 / 82 \\
1 / 21 / 83 \\
7 / 12 / 83 \\
5 / 09 / 85 \\
6 / 18 / 85\end{array}$ & $\begin{array}{r}23 \\
138 \\
13.2 \\
6.9 \\
98.2\end{array}$ & $\begin{array}{c}0.003 \\
- \\
- \\
- \\
0.006\end{array}$ & $\begin{array}{r}- \\
- \\
266 \\
3.6 \\
1.9\end{array}$ & $\begin{array}{l}\text { Pre-FTT } \\
\text { Rods G9 \&J8 } \\
\text { Post-FTT }\end{array}$ \\
\hline B03 & $\begin{array}{r}6 / 07 / 84 \\
12 / 10 / 84 \\
4 / 01 / 85\end{array}$ & $\begin{array}{l}35 \\
34 \\
36.2\end{array}$ & $\begin{array}{l}0.040 \\
0.014 \\
0.040\end{array}$ & $\begin{array}{l}23.5 \\
0.86 \\
0.52\end{array}$ & \\
\hline B41 & $\begin{array}{l}7 / 18 / 85^{(a)} \\
7 / 18 / 85\end{array}$ & $\begin{array}{c}56.4 \\
8.24\end{array}$ & - & $\begin{array}{l}0.78 \\
1.83\end{array}$ & \\
\hline B43 & $\begin{array}{r}3 / 06 / 84 \\
8 / 16 / 84 \\
12 / 17 / 84 \\
4 / 02 / 85\end{array}$ & $\begin{array}{l}81.0 \\
34.3 \\
21.8 \\
22.8\end{array}$ & $\begin{array}{l}0.09 \\
- \\
0.04 \\
0.08\end{array}$ & $\begin{array}{l}3.50 \\
0.325 \\
0.642 \\
3.30\end{array}$ & \\
\hline D01 & $\begin{array}{r}5 / 14 / 84 \\
12 / 1084 \\
4 / 02 / 85\end{array}$ & $\begin{array}{l}4.18 \\
2.45 \\
2.10\end{array}$ & $\begin{array}{l}0.14 \\
0.067 \\
0.066\end{array}$ & $\begin{array}{l}14.4 \\
0.187 \\
0.211\end{array}$ & Cs-137: 0.011 \\
\hline D04 & $\begin{array}{r}5 / 22 / 84 \\
12 / 12 / 84 \\
4 / 03 / 85\end{array}$ & $\begin{array}{l}2.17 \\
2.83 \\
1.47\end{array}$ & $\begin{array}{l}0.069 \\
0.0736 \\
0.0487\end{array}$ & $\begin{array}{l}0.127 \\
0.106 \\
0.215\end{array}$ & $\begin{array}{l}\text { Cs-137: } 0.007 ; M n-54: 0.009 \\
\text { Cs-137: } 0.003 ; M n-54: 0.005 ; \\
\text { Am-241:0.007 }\end{array}$ \\
\hline D06 & $\begin{array}{r}7 / 27 / 83 \\
1 / 19 / 84 \\
6 / 13 / 84 \\
12 / 13 / 84 \\
4 / 08 / 85\end{array}$ & $\begin{array}{l}2.51 \\
2.54 \\
2.60 \\
2.00 \\
1.12\end{array}$ & $\begin{array}{l}0.163 \\
0.112 \\
0.051 \\
0.0677 \\
0.0341\end{array}$ & $\begin{array}{c}- \\
\overline{-} \\
0.192 \\
0.353 \\
0.162\end{array}$ & $\begin{array}{l}\text { Cs-137: } 0.043 \\
\text { Mn-54:0.008 } \\
\text { Cs-137:0.004; Mn-54:0.004 } \\
\text { Am-241: } 0.008 ; \quad \text { Eu-154: } 0.005 ; \\
\text { Eu-155: } 0.0059\end{array}$ \\
\hline D09 & $\begin{array}{l}2 / 26 / 85 \\
3 / 04 / 85 \\
7 / 10 / 85\end{array}$ & $\begin{array}{l}6.04 \\
4.29 \\
2.03\end{array}$ & $\begin{array}{l}0.194 \\
0.135 \\
0.075\end{array}$ & $\begin{array}{l}0.531 \\
0.424 \\
0.334\end{array}$ & $\begin{array}{l}\text { Cs-137: } 0.021 \\
\text { Cs-137: } 0.008 ; E u-154: 0.004\end{array}$ \\
\hline
\end{tabular}




\section{TABLE E.3. (contd)}

\begin{tabular}{|c|c|c|c|c|c|}
\hline \multicolumn{2}{|c|}{ Fuel Data } & $\begin{array}{l}\text { Maximum } \\
{ }^{60} \mathrm{Co} \\
\end{array}$ & $\begin{array}{c}\text { Maximum } \\
{ }^{125} \mathrm{Sb} \\
\end{array}$ & $\begin{array}{c}\text { Maximum } \\
\text { Gross Beta }\end{array}$ & Comments/0ther \\
\hline D15 & $\begin{array}{l}7 / 27 / 83 \\
7 / 28 / 83 \\
7 / 28 / 83 \\
7 / 28 / 83 \\
1 / 23 / 84 \\
6 / 13 / 84\end{array}$ & $\begin{array}{l}1.62 \\
0.629 \\
0.168 \\
0.270 \\
1.31 \\
3.14\end{array}$ & $\begin{array}{c}0.109 \\
- \\
- \\
0.023 \\
0.112\end{array}$ & $\begin{array}{c}- \\
- \\
- \\
- \\
0.148\end{array}$ & $\begin{array}{l}\text { Pre-calorimeter } \\
\text { Post-calorimeter } \\
\text { Post-calorimeter } \\
\text { Post-calorimeter } \\
\text { Cs-137: } 0.488 ; M n-54: 0.004 \\
\text { Cs-137: } 0.0122 ; M n-54: 0.046 ; \\
\text { Am-241: } 0.0122\end{array}$ \\
\hline & $\begin{array}{r}12 / 14 / 84 \\
4 / 03 / 85\end{array}$ & $\begin{array}{l}3.86 \\
1.28\end{array}$ & $\begin{array}{l}0.110 \\
0.0451\end{array}$ & $\begin{array}{l}0.416 \\
0.198\end{array}$ & \\
\hline D16 & $\begin{array}{l}6 / 05 / 85 \\
6 / 05 / 85 \\
(a)\end{array}$ & $\begin{array}{l}2.31 \\
2.53\end{array}$ & $\begin{array}{l}0.0655 \\
0.0925\end{array}$ & $\begin{array}{l}2.68 \\
0.217\end{array}$ & Cs $-137: 0.004$ \\
\hline D18 & $\begin{array}{l}6 / 10 / 85 \\
6 / 10 / 85(a)\end{array}$ & $\begin{array}{l}3.74 \\
1.87\end{array}$ & $\begin{array}{l}0.129 \\
0.076\end{array}$ & $\begin{array}{l}0.332 \\
0.114\end{array}$ & \\
\hline D22 & $\begin{array}{l}2 / 26 / 85 \\
2 / 26 / 85(a) \\
7 / 10 / 85\end{array}$ & $\begin{array}{l}3.89 \\
4.21 \\
2.53\end{array}$ & $\begin{array}{l}0.127 \\
0.178 \\
0.082\end{array}$ & $\begin{array}{l}0.346 \\
0.149 \\
0.429\end{array}$ & $\begin{array}{l}\text { Cs-137: } 0.0155 \\
\text { Cs-137: } 0.0155 \\
\text { Cs-137: } 0.0079\end{array}$ \\
\hline D34 & $\begin{array}{l}3 / 27 / 84 \\
3 / 27 / 84(a) \\
8 / 17 / 84 \\
12 / 17 / 84 \\
7 / 11 / 84\end{array}$ & $\begin{array}{l}0.005 \\
0.375 \\
1.38 \\
2.10 \\
1.53\end{array}$ & $\begin{array}{l}0.00022 \\
0.00021 \\
0.525 \\
0.0808 \\
0.0483\end{array}$ & $\begin{array}{l}0.453 \\
0.898 \\
0.009 \\
0.414 \\
0.570\end{array}$ & $\begin{array}{l}\text { Cs-137: } 0.004 \\
\text { Cs-137: } 0.0126\end{array}$ \\
\hline D35 & $\begin{array}{l}6 / 13 / 85 \\
6 / 13 / 85(a)\end{array}$ & $\begin{array}{l}2.29 \\
1.61\end{array}$ & $\begin{array}{l}0.0733 \\
0.0521\end{array}$ & $\begin{array}{l}0.372 \\
0.236\end{array}$ & \\
\hline 040 & $\begin{array}{l}7 / 18 / 85 \\
7 / 18 / 85\end{array}$ & $\begin{array}{l}4.02 \\
3.20\end{array}$ & $\begin{array}{l}0.130 \\
0.0991\end{array}$ & $\begin{array}{l}0.858 \\
0.0607\end{array}$ & Cs-137: $0.015 ;$ Eu-154: 0.007 \\
\hline D46 & $\begin{array}{l}8 / 01 / 85 \\
8 / 01 / 85(a)\end{array}$ & $\begin{array}{l}4.13 \\
4.13\end{array}$ & $\begin{array}{l}0.151 \\
0.149\end{array}$ & $\begin{array}{l}0.787 \\
0.731\end{array}$ & $\begin{array}{ll}\text { Cs-137: } 0.016 ; A m-241: 0.015 \\
\text { Cs-137: } 0.014 ; A m-241: 0.0182 ; \\
\text { Eu-154: } 0.011\end{array}$ \\
\hline D47 & $8 / 05 / 85^{(a)}$ & 6.70 & 0.0950 & 1.180 & $\begin{array}{l}\text { Cs-137: } 0.028 ; \text { Am-241: } 0.023 ; \\
\text { Mn-54:0.016;; Eu-154: } 0.0147 ; \\
\text { Eu-155: } 0.218 \\
\text { Cs-137: } 0.011 ; \text { Am-241: } 0.011 ; \\
\text { Eu-154: } 0.00837\end{array}$ \\
\hline
\end{tabular}

(a) Contamination characterization data. 
TABLE E.4. Results of Canister Swipes

\begin{tabular}{|c|c|c|c|c|c|}
\hline $\begin{array}{l}\text { Fuel } \\
\text { Serial }\end{array}$ & $\begin{array}{l}\text { Date/ } \\
\text { Isotope } \\
\end{array}$ & $\begin{array}{l}\text { Mouth } \\
(\mu \mathrm{Ci}) \\
\end{array}$ & $\begin{array}{l}\text { Rail } \\
(\mu \mathrm{C} i)\end{array}$ & $\begin{array}{l}\text { Cruciform } \\
(\mu \mathrm{C} i)\end{array}$ & $\begin{array}{c}\text { Residue Sol/Insol. } \\
(\mu \mathrm{Ci} / \mathrm{g})\end{array}$ \\
\hline \multirow[t]{2}{*}{$\mathrm{B} 02$} & $10 / 18 / 82$ & & & & \\
\hline & ${ }^{60} \mathrm{Co}$ & 1.62 & 1.55 & 6.98 & 0.60 \\
\hline \multirow[t]{15}{*}{ B03 } & $6 / 08 / 84$ & & & & \\
\hline & ${ }^{60} \mathrm{Co}$ & 0.056 & 1.97 & 0.850 & $38.5 / 0.595$ \\
\hline & Gross Beta & 0.021 & 0.0142 & 0.0919 & 0.993 \\
\hline & ${ }^{137} \mathrm{Cs}$ & - & - & - & $(0.722)$ \\
\hline & ${ }^{137} \mathrm{Cs}$ & - & - & - & $(0.018)$ \\
\hline & ${ }^{57} \mathrm{Co}$ & - & - & - & $(0.054)$ \\
\hline & ${ }^{109} \mathrm{Cd}$ & - & - & - & $(0.427)$ \\
\hline & ${ }^{24} 1_{A m}$ & - & - & - & $(0.139)$ \\
\hline & ${ }^{106} \mathrm{Rh}$ & - & - & - & $(0.110)$ \\
\hline & $12 / 10 / 84$ & & & & \\
\hline & ${ }^{60} \mathrm{Co}$ & - & - & 0.919 & - \\
\hline & Gross Beta & - & - & 0.142 & - \\
\hline & $4 / 2 / 85$ & & & & \\
\hline & ${ }^{60} \mathrm{Co}$ & - & - & 0.350 & - \\
\hline & Gross Beta & - & - & 0.0387 & - \\
\hline \multirow[t]{5}{*}{ B41 } & $8 / 12 / 85$ & & & & \\
\hline & ${ }^{60} \mathrm{Co}$ & 0.260 & 3.75 & 4.50 & $79.2 / 1.99$ \\
\hline & ${ }^{137} \mathrm{Cs}$ & 0.00149 & 1.31 & 0.015 & $8.60 / 0.269$ \\
\hline & ${ }^{134} \mathrm{Cs}$ & - & - & - & $0.601 / 0.509$ \\
\hline & Gross Beta & 0.0563 & 0.897 & 0.990 & 57.96 \\
\hline \multirow[t]{7}{*}{ B43 } & $2 / 16 / 84$ & & & & \\
\hline & ${ }^{60} \mathrm{CO}$ & 9.97 & 0.204 & 3.88 & 2.77 \\
\hline & ${ }^{137} \mathrm{CS}$ & - & - & - & 0.135 \\
\hline & Gross Beta & 3.87 & 0.0103 & 7.28 & 0.00140 \\
\hline & $8 / 16 / 84$ & & & & \\
\hline & ${ }^{60} \mathrm{CO}$ & - & - & 0.00337 & - \\
\hline & Gross Beta & - & - & 0.000647 & - \\
\hline
\end{tabular}


TABLE E.4. (contd)

\begin{tabular}{|c|c|c|c|c|c|}
\hline $\begin{array}{l}\text { Fuel } \\
\text { Serial }\end{array}$ & $\begin{array}{l}\text { Date/ } \\
\text { Isotope }\end{array}$ & $\begin{array}{l}\text { Mouth } \\
(\mu \mathrm{C} i)\end{array}$ & $\begin{array}{l}\text { Rail } \\
(\mu \mathrm{C} i)\end{array}$ & $\begin{array}{l}\text { Cruciform } \\
(\mu \mathrm{C} i)\end{array}$ & $\begin{array}{c}\text { Residue Sol/Insol. } \\
(\mu \mathrm{Ci} / \mathrm{g})\end{array}$ \\
\hline & $\begin{array}{l}12 / 17 / 84 \\
{ }^{60} \mathrm{Co}\end{array}$ & - & - & 0.0123 & - \\
\hline & Gross Beta & - & - & 0.00123 & - \\
\hline & $4 / 2 / 85$ & & & & \\
\hline & ${ }^{60} \mathrm{Co}$ & - & - & 0.0193 & - \\
\hline & Gross Beta & - & - & 0.003 & - \\
\hline \multirow[t]{14}{*}{ D01 } & $5 / 17 / 84$ & & & & \\
\hline & ${ }^{60} \mathrm{Co}$ & 0.0212 & 0.113 & 0.713 & 1.01 \\
\hline & ${ }^{137} \mathrm{Cs}$ & - & 0.0008 & 0.00319 & - \\
\hline & $54_{M n}$ & - & - & 0.00391 & - \\
\hline & ${ }^{154} \mathrm{Sb}$ & - & - & 0.00100 & - \\
\hline & Gross Beta & 0.0167 & 0.0467 & 0.276 & 0.659 \\
\hline & $12 / 10 / 84$ & & & & \\
\hline & ${ }^{60} \mathrm{Co}$ & - & - & 0.316 & - \\
\hline & Gross Beta & - & - & 0.027 & - \\
\hline & $4 / 02 / 85$ & & & & \\
\hline & ${ }^{60} \mathrm{Co}_{\mathrm{O}}$ & - & - & 0.237 & - \\
\hline & ${ }^{137} \mathrm{Cs}$ & - & - & 0.00226 & - \\
\hline & ${ }^{154} \mathrm{Sb}$ & - & - & 0.00335 & - \\
\hline & Gross Beta & - & - & 0.0287 & - \\
\hline
\end{tabular}

D04 5/26/84

$\begin{array}{lcccc}{ }^{60}{ }_{\mathrm{Co}} & 0.0268 & 0.577 & 0.941 & 2.46 / 2.35 \\ { }^{137} \mathrm{Cs} & - & - & - & 10.254 \\ { }^{106}{ }_{\mathrm{Rh}} & - & - & - & 10.253 \\ { }^{125}{ }_{\mathrm{Sb}} & - & - & - & / 1.57 \\ \text { Gross Beta } & 0.127 & 0.144 & 0.0465 & 4.76 / \\ 12 / 12 / 84 & & & & \\ 60_{\mathrm{Co}} & - & - & 2.29 & - \\ \text { Gross Beta } & - & - & 0.101 & -\end{array}$

$$
\text { E.8 }
$$


TABLE E.4. (contd)

\begin{tabular}{|c|c|c|c|c|c|}
\hline $\begin{array}{l}\text { Fuel } \\
\text { Serial }\end{array}$ & $\begin{array}{l}\text { Date/ } \\
\text { Isotope }\end{array}$ & $\begin{array}{l}\text { Mouth } \\
(\mu \mathrm{C} i)\end{array}$ & $\begin{array}{l}\text { RaiT } \\
\left(\mu C_{i}\right)\end{array}$ & $\begin{array}{l}\text { Cruciform } \\
(\mu \mathrm{C} i)\end{array}$ & $\begin{array}{c}\text { Residue Sol/Insol. } \\
(\mu \mathrm{C} \mathrm{i} / \mathrm{g})\end{array}$ \\
\hline & $\begin{array}{l}4 / 03 / 85 \\
60 \mathrm{Co}\end{array}$ & - & - & 0.999 & - \\
\hline & Gross Beta & - & - & 0.109 & - \\
\hline
\end{tabular}

D06 6/24/83

${ }^{60} \mathrm{Co}$

$0.106 \quad 0.0111 \quad 0.0161$

$969 / .00453$

$1 / 19 / 84$

${ }^{60} \mathrm{Co}$

${ }^{125} \mathrm{Sb}$

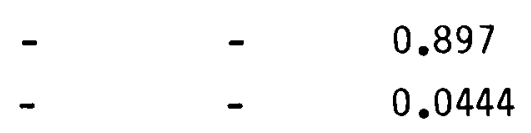

$6 / 13 / 84$

${ }^{60} \mathrm{Co}$

${ }^{125} \mathrm{Sb}$

- $\quad$ - 0.147

Gross Beta

$\begin{array}{lll}- & - & 0.00582\end{array}$

$12 / 13 / 84$

${ }^{60} \mathrm{Co}$

${ }^{137} \mathrm{Cs}$

$\begin{array}{lll}- & - & 6.39\end{array}$

Gross Beta

- $\quad 0.0166$

$4 / 08 / 85$

${ }^{60} \mathrm{Co}$

${ }^{125} \mathrm{Sb}$

$\begin{array}{lll}- & - & 2.71\end{array}$

Gross Beta

- $\quad 0.0672$

- $\quad-$

0.359

D09 3/04/85

${ }^{60} \mathrm{Co}$

${ }^{137} \mathrm{Cs}$

${ }^{134} \mathrm{Cs}$

$\begin{array}{lll}0.265 & 0.322 & 0.381\end{array}$

43.6

- $\quad-\quad$ -

0.00147

Gross Beta

0.0498

$-$

$-$

0.00024

$7 / 10 / 85$

${ }^{60} \mathrm{Co}_{\mathrm{O}}$

$\begin{array}{lll}- & - & 0.0459 \\ - & - & 0.0187\end{array}$

Gross Beta

0.038

0.054

0.386

E.9 


\section{TABLE E.4. (contd)}

\begin{tabular}{|c|c|c|c|c|c|}
\hline $\begin{array}{l}\text { Fuel } \\
\text { Serial } \\
\end{array}$ & $\begin{array}{l}\text { Date/ } \\
\text { Isotope } \\
\end{array}$ & $\begin{array}{l}\text { Mouth } \\
(\mu \mathrm{C} i)\end{array}$ & $\begin{array}{l}\text { Rail } \\
(\mu \mathrm{C} i)\end{array}$ & $\begin{array}{l}\text { Cruci form } \\
\quad(\mu \mathrm{C} i) \\
\end{array}$ & $\begin{array}{l}\text { Residue Sol/Insol } \\
(\mu \mathrm{C} / \mathrm{g})\end{array}$ \\
\hline \multirow[t]{14}{*}{ D15 } & $7 / 27 / 83$ & & & & \\
\hline & ${ }^{60} \mathrm{Co}$ & 0.0139 & 0.0109 & 0.288 & 0.270 \\
\hline & ${ }^{106} 6_{\mathrm{Rh}}$ & 0.0006 & - & - & - \\
\hline & Gross Beta & 0.0425 & 0.0284 & 0.0275 & 0.320 \\
\hline & $\begin{array}{l}1 / 23 / 84 \\
{ }^{60} \mathrm{Co}\end{array}$ & - & - & 0.0009 & - \\
\hline & $6 / 13 / 84$ & & & & \\
\hline & ${ }^{60} \mathrm{Co}_{\mathrm{O}}$ & - & - & 0.0006 & - \\
\hline & Gross Beta & - & - & 0.0003 & - \\
\hline & $12 / 14 / 84$ & & & & \\
\hline & ${ }^{60} \mathrm{Co}$ & - & - & 0.0128 & - \\
\hline & Gross Beta & - & - & 0.00055 & - \\
\hline & $4 / 03 / 85$ & & & & \\
\hline & ${ }^{60} \mathrm{Co}$ & - & - & 0.337 & - \\
\hline & Gross Beta & - & - & 0.0113 & - \\
\hline
\end{tabular}

D16 6/05/85

$\begin{array}{lcccc}{ }^{60} C_{0} & 0.00575 & 0.119 & 0.231 & 0.0503 / 2.87 \\ { }^{137} C_{S} & - & - & - & 10.194 \\ \text { Gross Beta } & 0.00423 & 0.0433 & 0.0771 & -\end{array}$

D18 6/10/85

$\begin{array}{lllll}{ }^{60} \text { Co } & 0.00229 & 0.193 & 0.0803 & 23.6 / 0.0450 \\ \text { Gross Beta } & 0.00157 & 0.0708 & 0.0346 & -\end{array}$

D22 $2 / 26 / 85$

$\begin{array}{lcccl}{ }^{60}{ }_{\text {Co }} & 0.0242 & 3.73 & 0.956 & 0.103 / 0.984 \\ { }^{137}{ }_{C s} & - & - & - & 0.0002 / 0.240 \\ \text { Gross Beta } & 0.00842 & 0.683 & 0.0378 & 0.0061 / 0.0547\end{array}$


TABLE E.4. (contd)

\begin{tabular}{|c|c|c|c|c|c|}
\hline $\begin{array}{c}\text { Fuel } \\
\text { Serial }\end{array}$ & $\begin{array}{l}\text { Date/ } \\
\text { Isotope } \\
\end{array}$ & $\begin{array}{l}\text { Mouth } \\
(\mu \mathrm{C} i)\end{array}$ & $\begin{array}{l}\text { Rail } \\
(\mu \mathrm{Ci})\end{array}$ & $\begin{array}{c}\text { Cruciform } \\
(\mu \mathrm{C} i)\end{array}$ & $\begin{array}{c}\text { Residue Sol/Insol. } \\
(\mu \mathrm{Ci} / \mathrm{g})\end{array}$ \\
\hline & $\begin{array}{l}7 / 10 / 85 \\
{ }^{60} \mathrm{Co}\end{array}$ & - & - & 0.396 & - \\
\hline & Gross Beta & - & - & 0.0926 & - \\
\hline \multirow[t]{14}{*}{$D-34$} & $4 / 02 / 84$ & & & & \\
\hline & ${ }^{60} \mathrm{Co}$ & 0.0104 & 0.550 & 0.0551 & $2.05 / 0.625$ \\
\hline & ${ }^{54} \mathrm{Mn}$ & - & - & - & 10.00568 \\
\hline & ${ }^{125} \mathrm{Sb}$ & - & - & - & 10.127 \\
\hline & Gross Beta & - & - & - & $1.30 /$ \\
\hline & $8 / 17 / 84$ & & & & \\
\hline & ${ }^{60} \mathrm{Co}$ & - & - & 0.0240 & - \\
\hline & ${ }^{125} \mathrm{Sb}$ & - & - & 0.0003 & - \\
\hline & $12 / 17 / 84$ & & & & \\
\hline & ${ }^{60} \mathrm{Co}$ & - & - & 0.00971 & - \\
\hline & Gross Beta & - & - & 0.0006 & - \\
\hline & $7 / 11 / 85$ & & & & \\
\hline & ${ }^{60} \mathrm{Co}$ & - & - & 0.0707 & - \\
\hline & Gross Beta & - & - & 0.0117 & - \\
\hline \multirow[t]{4}{*}{ D35 } & $6 / 13 / 85$ & & & & \\
\hline & ${ }^{60} \mathrm{Co}$ & 0.0437 & 0.607 & 0.228 & $0.892 / 6.51$ \\
\hline & ${ }^{125} \mathrm{Sb}$ & - & - & - & $/ 0.743$ \\
\hline & Gross Beta & 0.0255 & 0.0983 & 0.0696 & $0.501 /$ \\
\hline \multirow[t]{3}{*}{ D40 } & $7 / 18 / 85$ & & & & \\
\hline & ${ }^{60} \mathrm{Co}$ & 0.165 & 2.30 & 0.087 & 0.000147 \\
\hline & Gross Beta & 0.0625 & 0.303 & 0.0364 & 0.00313 \\
\hline \multirow[t]{3}{*}{ D46 } & $8 / 06 / 85$ & & & & \\
\hline & ${ }^{60} \mathrm{Co}$ & - & 2.67 & 0.265 & 92.7 \\
\hline & Gross Beta & - & 0.408 & 0.0303 & 93.0 \\
\hline
\end{tabular}


TABLE E.4. (contd)

\begin{tabular}{|c|c|c|c|c|c|}
\hline $\begin{array}{l}\text { Fuel } \\
\text { Serial }\end{array}$ & $\begin{array}{l}\text { Date/ } \\
\text { Isotope }\end{array}$ & $\begin{array}{l}\text { Mouth } \\
(\mu \mathrm{C} i)\end{array}$ & $\begin{array}{l}\text { Rail } \\
(\mu \mathrm{C} i)\end{array}$ & $\begin{array}{l}\text { Cruciform } \\
(\mu \mathrm{Ci})\end{array}$ & $\begin{array}{c}\text { Residue Sol/Insol. } \\
(\mu \mathrm{C} \mathrm{i} / \mathrm{g})\end{array}$ \\
\hline \multirow[t]{10}{*}{ D47 } & $8 / 05 / 85$ & & & & \\
\hline & ${ }^{60} \mathrm{Co}_{\mathrm{O}}$ & 0.103 & 0.896 & 0.510 & $0.0149 / 7.19$ \\
\hline & ${ }^{137} \mathrm{Cs}$ & - & - & - & $/ 16.3$ \\
\hline & ${ }^{134} \mathrm{Cs}$ & - & - & - & 10.469 \\
\hline & ${ }^{154} \mathrm{Eu}$ & - & - & - & $/ 1.00$ \\
\hline & ${ }^{155} \mathrm{Eu}$ & - & - & - & 10.720 \\
\hline & ${ }^{106} 6_{\mathrm{Rh}}$ & - & - & - & $/ 1.10$ \\
\hline & $241_{A m}$ & - & - & - & $/ 1.69$ \\
\hline & ${ }^{125} \mathrm{Sb}$ & - & - & - & 10.783 \\
\hline & Gross Beta & 0.0211 & 0.0915 & 0.0810 & $85.0 /$ \\
\hline
\end{tabular}




\section{DISTRIBUTION}

No. of

Copies

\section{OFFSITE}

30 DOE Technical Information Center

H. J. Hale

Office of Civilian Radioactive Waste Management

U.S. Department of Energy

$\mathrm{RW}-30$

Washington, DC 20585

J. Epstein

Office of Civilian Radioactive Waste Management

U.S. Department of Energy

RW-32

Washington, DC 20585

J. R. Hilley

Office of Civilian Radioactive Waste Management

U.S. Department of Energy

$\mathrm{RW}-30$

Washington, DC 20585

K. A. Klein

Office of Civilian Radioactive Waste Management

U.S. Department of Energy

$\mathrm{RW}-30$

Washington, DC 20585

D. E. Shelor

Office of Civilian Radioactive Waste Management

U.S. Department of Energy

$\mathrm{RW}-32$

Washington, DC 20585
No. of

Copies

W. Stringfield

Office of Civilian Radioactive Waste Management

U.S. Department of Energy

$\mathrm{RW}-32$

Washington, DC 20585

L. Barrett

Office of Civilian Radioactive Waste Management

U.S. Department of Energy

RW-33

Washington, DC 20585

C. W. Conner

Office of Civilian Radioactive Waste Management

U.S. Department of Energy

RW-33

Washington, DC 20585

J. S. Finucane

Energy Information

Administration

U.S. Department of Energy

EI-53

Washington, DC 20585

H. Steinberg

U.S. Department of Energy

Office of Storage and

Transportation Systems

$\mathrm{RW}-33$

1000 Independence Avenue

Washington, DC 20585

C. J. Dankowski

U.S. Department of Energy Defense Programs

San Francisco Operations office 1333 Broadway

Oakland, CA 94612 
No. of

Copies

M. Fisher

U.S. Department of Energy

Idaho Operations office

550 Second Street

Idaho Falls, ID 83401

K. G. Golliher

U.S. Department of Energy

P.0. Box 5400

Albuquerque Operations office

Albuquerque, NM 87115

S. Mann

U.S. Department of Energy

Chicago Operations Office

Argonne, IL 60439

M. Kunich

U.S. Department of Energy

P.0. Box 14100

Nevada Operations Office

Las Vegas, NV 89114

C. Matthews

U.S. Department of Energy

Oak Ridge Operations Office

P.0. Box E

Oak Ridge, TN 37830

J. 0. Neff

U.S. Department of Energy

Salt Repository Project Office

505 King Avenue

Columbus, $\mathrm{OH} 43201$

W. Newcomb

Office of Waste Technology

Development

7000 S. Adams Street

Willowbrook, IL 60521

B. A. Chin

Auburn University

Mechanical Engineering Dept.

247 Wilmore Laboratories

Auburn, AL 36830
No. of

Copies

L. A. Walton

Babcock \& Wilcox Co.

P.0. Box 10935

Lynchburg, VA 24506-0935

P. A. File

Baltimore Gas and Electric Co.

Calvert $\mathrm{Cl}$ iffs Nuclear Power Plant

Lusby, M0 20657

J. A. Carr

Battelle Project Management Division

Office of Nuclear

Waste Isolation

505 King Avenue

Columbus, $\mathrm{OH} 43201$

Battelle Memorial Institute

Project Management Division

Technical Library

$505 \mathrm{King}$ Avenue

Columbus, $\mathrm{OH} 43201$

V. Pasupathi

Battelle Columbus Division

505 King Avenue

Columbus, $\mathrm{OH} 43201$

T. W. Wood

Battelle Memorial Institute

Washington Operations

2030 M Street-NW

Suite 800

Washington, DC 20036

G. A. Townes

BE Inc.

P.0. Box 145

New Ellenton, SC 29809

L. J. Jardine

Bechtel National

P.0. Box 3965

San Francisco, CA 94119 
No. of

Copies

R. L. Hails

Bechtel Power Corporation

15740 Shady Grove Rd. Gaithersburg, MD 20760

R. Kunita

Carolina Power \& Light Co.

P.0. Box 1551

Raleigh, NC 27602

G. C. Jobson

Chem-Nuclear Systems, Inc. One Greystone West Building

240 Stoneridge Drive, Suite 100

Columbia, SC 29210

C. K. Anderson

Combustion Engineering, Inc.

C-E Power Systems

1000 Prospect Hill Road

Windsor, CT 06095

N. Fuhrman

Combustion Engineering, Inc.

C-E Power Systems

1000 Prospect Hill Road

Windsor, CT 06095

R. L. Moscardini

Combustion Engineering, Inc. 1000 Prospect Hill Road

Windsor, CT 06095

G. P. Wagner

Commonwealth Edison

Nuclear Stations Division

P.0. Box 767

Chicago, IL 60690

T. J. Marz

Consumers Power Company

1945 W. Parnall Road

Jackson, MI 49201

S. J. Raffety

Dairyland Power Coop.

2615 E. Ave. S.

LaCrosse, WI 54601
No. of

Copies

R. W. Rasmussen

Duke Power Company

P.0. Box 33189

Charlotte, NC 28242

EBASCO Services Incorporated

Two World Trade Center

New York, NY 10048

R. Stanford

Edison Electric Institute

1111 19th St., NW

Washington, DC 20036

M. F. Jensen

EG\&G Idaho, Inc.

P.0. Box 1625

Idaho Falls, ID 83415

R. F. Williams

Electric Power Research Institute

P.0. Box 10412

Palo Alto, CA 94303

R. W. Lambert

Electric Power Research Institute

P.0. Box 10412

Palo Alto, CA 94303

G. T. Zamry

Florida Power \& Light Co. 9250 W. Flagler St.

Miami, FL 33174

FLUOR Engineers, Inc. Advanced Technology Division P.0. Box C- 11944

Santa Ana, CA 92711-1944

B. K. Agarwal

FW Energy Applications, Inc. 110 So. Orange Ave. Livingston, NJ 07039 
No. of

Copies

B. J. Baxter

GA Technologies Inc.

P.0. Box 81608

San Diego, CA 92138

E. E. Voil and

General Electric Co.

Nuclear Fuel and Services

Division

7555 E. Collins Road

Morris, IL 60450

W. L. Dobson

Gilbert Associates, Inc.

P.0. Box 1498

Reading, PA 19603

V. J. Barnhart

GNS I

135 Darling Dr.

Avon, CT 06001

B. Handly

Houston Lighting \& Power Co.

Nuclear Fuels-SPII

12301 Kurland Dr.

Houston, TX 77034

E. R. Johnson

11702 Bowman Green Drive

Reston, VA 22090

J. A. McBride

E. R. Johnson Associates, Inc.

11702 Bowman Green Drive

Reston, VA 22090

L. B. Ballou

Lawrence Livermore National Laboratory

P.0. Box 808

Livermore, CA 94550

C. F. Smith

Lawrence Livermore National Laboratory

P.0. Box 808

Livermore, CA 94550
No. of

Copies

\author{
L. M. Trosten \\ LeBoeuf, Lamb, Leiby, \& MacRae \\ 1333 New Hampshire Ave. NW \\ Washington, DC 20036 \\ L. D. Ramspott \\ Lawrence Livermore National \\ Laboratory \\ P.0. Box 808 \\ Mail Stop L404 \\ Livermore, CA 94550 \\ V. M. Oversby \\ Waste Package Task, NNWSI \\ Lawrence Livermore National \\ Laboratory \\ P.0. Box 808 \\ L206 \\ Livermore, CA 94550 \\ H. F. Shaw \\ Waste Package Task, NNWSI \\ Lawrence Livermore National \\ Laboratory \\ P.0. Box 808 \\ L206 \\ Livermore, CA 94550
}

M. Schwartz

Lawrence Livermore National Laboratory

P.0. Box 808

Mailstop L197

Livermore, CA 94550

J. H. Garrity

Maine Yankee Atomic Power Co. Edison Drive

August, ME 04336

G. D. Whittier

Maine Yankee Atomic Power Co.

Edison Drive

Augusta, ME 04336 
No. of

Copies

R. Whale

Michigan Public Service

Commission

6545 Mercantile Way

Lansing, MI 48909

R. Calabro

Northeast Utilities Service Co. P.0. Box 270

Hartford, CT 06101

R. Isakson

Northeast Utilities Service Co. P.0. Box 270

Hartford, CT 06101

E. Krinick

Northeast Utilities Service Co. P.0. Box 270

Hartford, CT 06101

J. Houston

Nuclear Assurance Corp.

5720 Peach Tree Parkway

Norcross, GA 30092

J. M. Viebrock

Nuclear Assurance Corp.

5720 Peachtree Parkway

Norcross, GA 30092

J. Clark

Nuclear Fuel Services

6000 Executive Blvd.

Rockville, MD 20852

R. T. Haelsig

Nuclear Packaging Inc.

1010 S. 336th St.

Federal Way, WA 98003

G. J. Antonucci

NUS Corporation

910 Clopper Rd.

Gaithersburg, MD 20878
No. of

Copies

J. V. Massey

Reedy and Associates

103 Albright Way

Los Gatos, CA 95030

B. Lehnert

NUTECH Engineers

145 Martinvale Lane

San Jose, CA 95119

J. Van Cleve

Dak Ridge National Laboratory

P.0. Box $X$

Dak Ridge, TN 37831

M. Litterman

Portland General Electric,

Trojan Fuel

121 S.W. Salmon St.

Portland, OR 97204

D. Woods

Ralph M. Parsons Co.

100 West Walnut Street

Pasadena, CA 91124

G. C. Allen

Sandia National Laboratory

Division 6323

Transportation Technology Center

P.0. Box 5800

Albuquerque, NM 87185

J. F. Ney

Sandia National Laboratory

Division 6323

Transportation Technology Center

P.0. Box 5800

Albuquerque, NM 87185

T. L. Sanders

Sandia National Laboratory

P.0. Box 5800

Albuquerque, NM 87185 
No. of

Copies

E. Kuhns

Stone and Webster Engineering Corp.

1 Penn Plaza

250 W. 34th St.

New York, NY 10119

J. B. Moegling

Tennessee Valley Authority

404 Krystal Building

Chattanooga, TN 37401

E. Gordon

Transnuclear, Inc.

507 Newmark Esplanade

Rockville, MD 20850

J. Mangusi

Transuclear, Inc.

1 N. Broadway

White Plains, NY 10601

B. R. Teer

Transnuclear, Inc.

1 N. Broadway

White Plains, NY 10601

TRW Exploration/Pro.

P.0. Box 441807

Houston, TX 77244-1807

C. E. King

Uranium Mgt. Corp.

175 Curtner Avenue

MC620

San Jose, CA 95125

N. H. Davison

U.S. Nuclear Regulatory Commission

Office of Nuclear Materials Safety and Safeguards

Washington, DC 20555
No. of

Copies

C. Feldman

U.S. Nuclear Regulatory

Commission

Office of Nuclear Regulatory

Research

MS-1130-SS

Washington, DC 20555

W. Lake

U.S. Nuclear Regulatory Commission

Office of Nuclear Materials

Safety and Safeguards

MS-396-SS

Washington, DC 20555

J. Roberts

U.S. Nuclear Regulatory Commission

Office of Nuclear Materials

Safety and Safeguards

MS-346-SS

Washington, DC 20555

C. H. Peterson

U.S. Nuclear Regulatory Commission

Office of Nuclear Materials

Safety and Safeguards

MS-623-SS

Washington, DC 20555

L. C. Rouse

U.S. Nuclear Regulatory Commission

Spent Fuel Storage Installation

Division of Fuel Cycle and

Material Safety

Washington, DC 20555

S. P. Turel

U.S. Nuclear Regulatory Commission

Office of Nuclear Regulatory Research

Washington, DC 20555 
No. of

Copies

W. J. Wachter

U.S. Tool and Die, Inc. 4030 Route 8

Allison Park, PA 15101

G. E. Lucas

University of California

Dept. of Chemical and Nuclear Engineering

Santa Barbara, CA 93106

M. L. Smith

Virginia Electric \& Power

5000 Dominion Blvd.

Glen Allen, VA 23060

J. A. Nevshemal

P.0. Box 386

Beaver, PA 15009-0386

E. S. Bassler

Westinghouse Electric Corp.

Box 2728

Pittsburgh, PA 15230

C. F. Davis

Westinghouse Electric Corp.

Waste Technology Services Div.

P.0. Box 10864

Pittsburgh, PA 15236

A. R. Hak 1

Westinghouse Electric Corp.

Waste Technology Services Div.

P.0. Box 10864

Pittsburgh, PA 15236

J. B. Wright

Westinghouse Electric Corp.

Waste Technology Services Div.

P.0. Box 10864

Pittsburgh, PA 15236

N. Dayem

R. F. Weston Co.

955 L Enfant Plaza SW 8th Floor

Washington, DC 20024-2119
No. of

Copies

E. Benz

R. F. Weston Co.

955 L Enfant Plaza SW 8th Floor

Washington, DC 20024-2119

ONSITE

5 DOE Richland Operations office
J. P. Collins
D. E. Crouter
M. S. Karol
0 . L. 01 son
J. J. Sutey

3 Westinghouse Hanford Company

M. B. Arndt

C. L. Brown

G. T. Harper

69 Pacific Northwest Laboratory

M. J. Apted

W. J. Bailey

J. 0. Barner

G. H. Beeman

C. E. Beyer

D. J. Bradley

J. L. Braitman

T. K. Campbe11

J. M. Creer (5)

M. E. Cunningham

D. G. Doran

R. E. Einziger

M. D. Freshley

E. R. Gilbert (10)

R. J. Guenther

C. M. Heeb

R. E. Heineman

D. K. Hilliard

U. P. Jenquin

A. B. Johnson, Jr. (15)

R. W. Knoll

M. R. Kreiter

D. D. Lanning

M. A. Mckinnon

G. L. McVay 
No. of

Copies

L. G. Morgan

J.T.A. Roberts

R. I. Smith

J. L. Straalsund
No. of

Copies

C. K. Thornhil1

F. R. Zaloudek (5)

Publishing Coordination (2)

Technical Report Files (5) 